\title{
Royal Coachman (41CM111) An Early Middle Archaic Site along Cordova Creek in Comal County, Texas
}

\author{
Richard B. Mahoney
}

Harry J. Shafer

Steve A. Tomka

Lee C. Nordt

Raymond P. Mauldin

Center for Archeological Research, University of Texas at San Antonio

Follow this and additional works at: https://scholarworks.sfasu.edu/ita

Part of the American Material Culture Commons, Archaeological Anthropology Commons, Environmental Studies Commons, Other American Studies Commons, Other Arts and Humanities Commons, Other History of Art, Architecture, and Archaeology Commons, and the United States History Commons

Tell us how this article helped you.

This Article is brought to you for free and open access by the Center for Regional Heritage Research at SFA ScholarWorks. It has been accepted for inclusion in Index of Texas Archaeology: Open Access Gray Literature from the Lone Star State by an authorized editor of SFA ScholarWorks. For more information, please contact cdsscholarworks@sfasu.edu. 


\section{Royal Coachman (41CM111) An Early Middle Archaic Site along Cordova Creek in Comal County, Texas}

\section{Licensing Statement}

This is a work produced for the Texas Department of Transportation (TxDOT) by the report producer. TXDOT and the report producer jointly own all rights, title, and interest in and to all intellectual property developed under TXDOT's contract with the report producer. The report may be cited and brief passages from this publication may be reproduced without permission provided that credit is given to both TXDOT and the report producer. Permission to reprint an entire chapter, section, figures or tables must be obtained in advance from either the Supervisor of the Archeological Studies Branch, Environmental Affairs Division, Texas Department of Transportation, 125 East 11th Street, Austin, Texas, 78701 or from the report producer. 


\section{Royal Coachman (41CM111)}

\section{An Early Middle Archaic Site along Cordova Creek in Comal County, Texas}

by

Richard B. Mahoney, Harry J. Shafer, Steve A. Tomka, Lee C. Nordt, and Raymond P. Mauldin

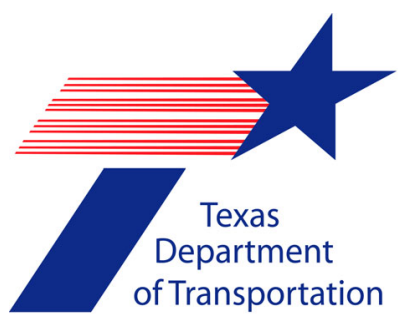

Environmental Affairs Division Texas Department of Transportation Archeological Studies Program, Report No. 49

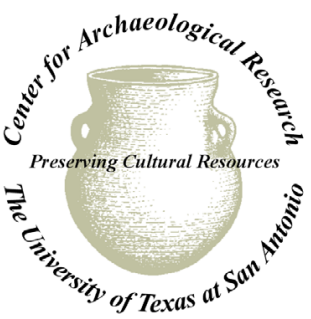

Center for Archaeological Research The University of Texas at San Antonio Archaeological Survey Report, No. 332 
ISBN: 1-930788-22-3 


\title{
Royal Coachman (41CM111)
}

\section{An Early Middle Archaic Site along Cordova Creek in Comal County, Texas}

\author{
by \\ Richard B. Mahoney, Harry J. Shafer, Steve A. Tomka, \\ Lee C. Nordt, and Raymond P. Mauldin
}

Texas Antiquities Committee Permit No. 2807

Raymond P. Mauldin

Principal Investigator

Work Authorization No. 57008PD004

Contract No. 570XXPD004

Prepared for:

Texas Department of Transportation

Environmental Affairs Division

Archeological Studies Program, Report No. 49

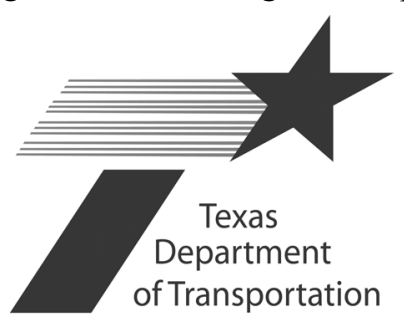

Prepared by:

Center for Archaeological Research The University of Texas at San Antonio Archaeological Survey Report, No. 332

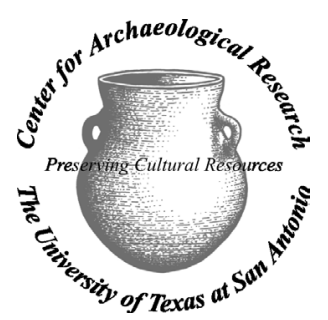




\title{
Royal Coachman (41CM111)
}

\section{An Early Middle Archaic Site along Cordova Creek in Comal County, Texas}

\author{
Copyright ${ }^{{ }^{\circ}} 2003$ \\ Texas Department of Transportation (TxDOT) and Center for Archaeological Research, \\ The University of Texas at San Antonio (CAR-UTSA)
}

\begin{abstract}
All rights reserved
TxDOT and CAR-UTSA jointly own all rights, title, and interest in and to all data and other information developed for this project under Contract 570XXPD004. Brief passages from this publication may be reproduced without permission provided that credit is given to TxDOT and CAR-UTSA. Permission to reprint an entire chapter, section, figures or tables must be obtained in advance from the Supervisor of the Archeological Studies Program, Environmental Affairs Division, Texas Department of Transportation, 125 East 11th Street, Austin, 78701. Copies of this publication have been deposited with the Texas State Library in compliance with the State Depository requirements.
\end{abstract}

Printed by Kwik Kopy Printing on Main, San Antonio, Texas

2003

jointly published by

Texas Department of Transportation

Environmental Affairs Division

Archeological Studies Program

Owen Lindauer, Ph.D., Supervisor

Archeological Studies Program, Report No. 49

A. McGraw, Series Editor

and

Center for Archaeological Research

The University of Texas at San Antonio

Archaeological Survey Report, No. 332 


\section{Abstract:}

The Royal Coachman site, 41CM111, is bisected by FM 306 near the highway's eastern crossing of the Guadalupe River. Archeologists from the Texas Department of Transportation conducted extensive excavations at the site in 1980 and the Center for Archaeological Research carried out fieldwork related to geomorphic assessment of the deposits in 2002. The site contains at least three archeological components, an upper zone that may be of late Middle Archaic age and two commingled lower zones that are early Middle Archaic in age and contain a mix of Nolan/ Pandale and Bell-Andice/Early Triangular points. The deeper, more strongly manifested archeological components are associated with a dense burned rock sheet midden composed of two in situ features among a dense scatter of highly disturbed burned rock. Radiocarbon assays place this zone at between 5320-5880 years BP. The lithic assemblage is suggestive of tool manufacture and retooling activities and the projectile point collection is dominated by Early Triangular points and preforms.

It is the recommendation of CAR that site 41CM111 warrants designation as a State Archeological Landmark and is eligible for listing on the National Register of Historic Places because of its significant contribution to a better understanding of the regional archeological record. We believe that these investigations have resulted in an appropriate level of work to evaluate the archeological property within the highway ROW and no further work is currently recommended. We also recommend that TxDOT consider avoidance as an option during future construction activities to avert impact to remaining deposits. In addition, if new ROW is acquired, additional work is warranted to determine the extent and significance of currently unidentified material. This work was conducted under Texas Antiquities Committee Permit No. 2807. 


\section{Table of Contents:}

Abstract .
Figures
Tables nowledgments .
Chapter 1: Introduction by Richard B. Mahoney
Introduction

Chapter 2: Environmental Setting by Steve A. Tomka, Richard B. Mahoney, and Raymond P. Mauldin

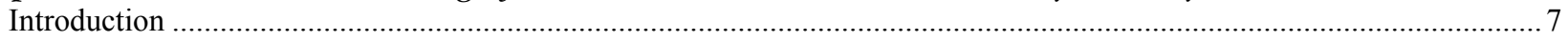

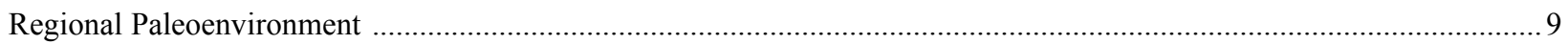

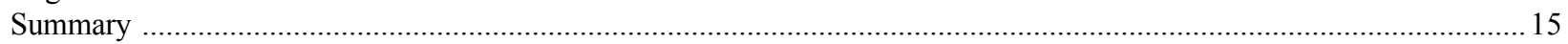

Chapter 3: Archeological Background by Richard B. Mahoney

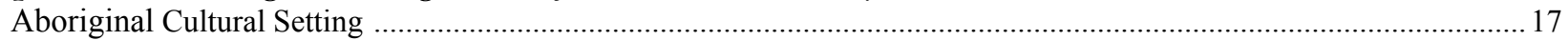

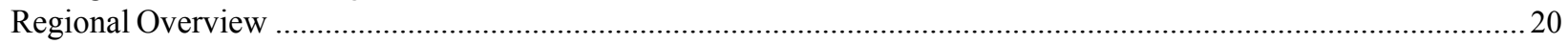

Previously Recorded Sites along the Guadalupe River in Comal County ........................................................................220

Chapter 4: Research Perspective by Steve A Tomka and Raymond P. Mauldin

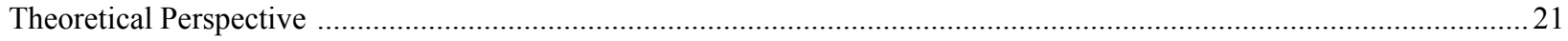

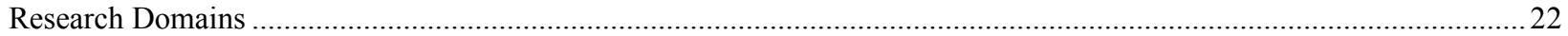

Chapter 5: Field and Laboratory Methods by Richard B. Mahoney

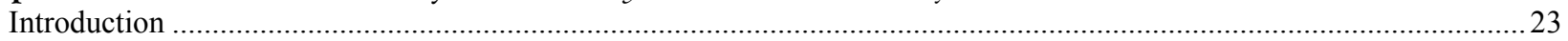

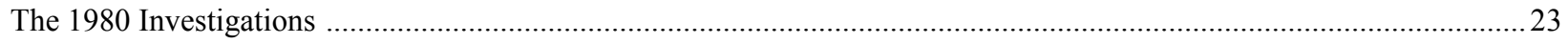

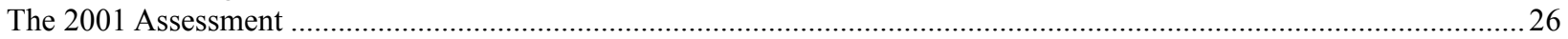

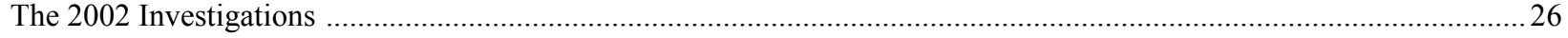

Chapter 6: Geoarcheology by Lee C. Nordt

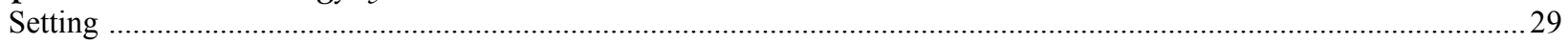

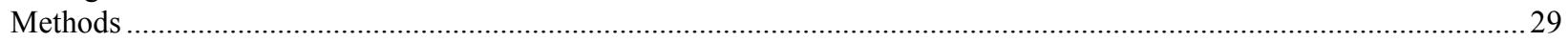

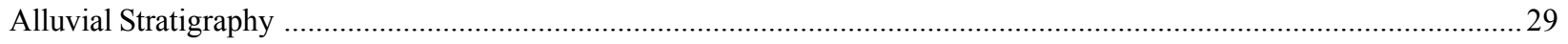

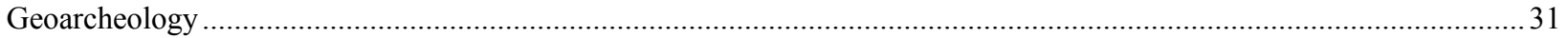

Chapter 7: Results of Investigations by Richard B. Mahoney, Harry J. Shafer, and Steve A. Tomka

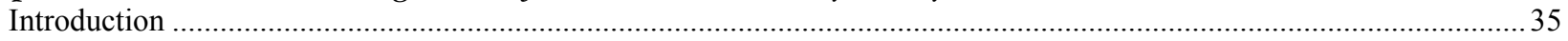

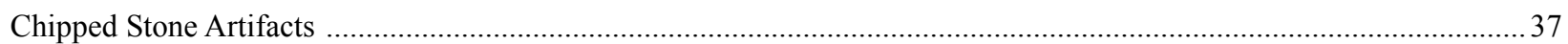

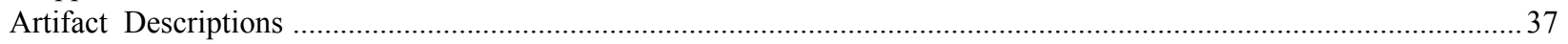

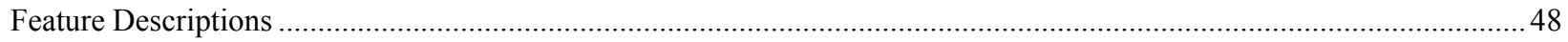

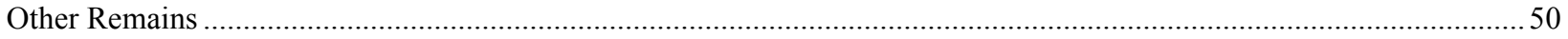

Chapter 8: Site Integrity and Chronology by Richard B. Mahoney, Harry J. Shafer, and Steve A. Tomka

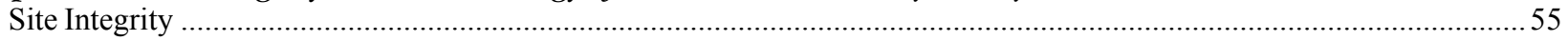

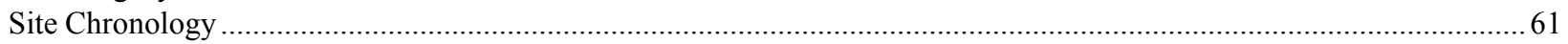

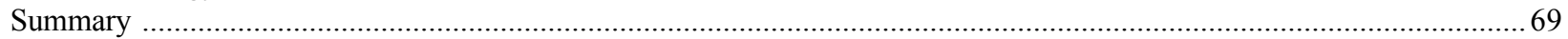

Chapter 9: Burned Rock Features by Richard B. Mahoney, Harry J. Shafer, and Steve A. Tomka

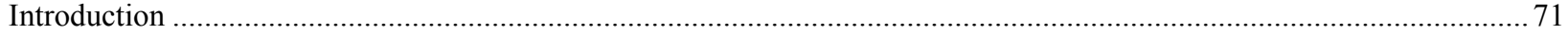

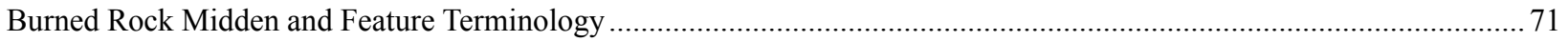

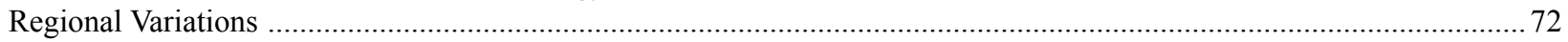

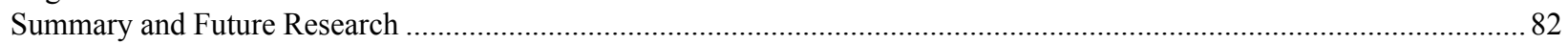

Chapter 10: Early Middle Archaic Lithic Assemblages by Harry J. Shafer and Steve A. Tomka

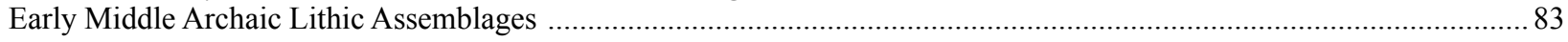

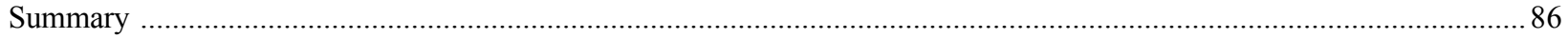

Chapter 11: Summary and Conclusions by Steve A. Tomka, Richard B. Mahoney, and Harry J. Shafer

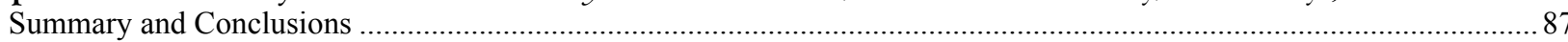




\section{References Cited}

References Cited .

Appendix A: Soil-Stratigraphic Descriptions by Lee C. Nordt

Soil-Stratigraphic Descriptions

Appendix B: Radiocarbon Dating Results

Radiocarbon Dating Results

Appendix C: Magnetic Sediment Susceptibility by Raymond P. Mauldin

Magnetic Sediment Susceptibility 


\section{Figures:}

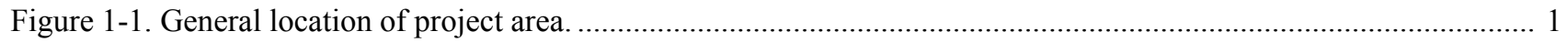

Figure 1-2. View of surface scatter along north side of FM 306 prior to 1980 excavations. ......................................... 2

Figure 1-3. Plan view of 1980 main excavation block depicting surface of the burned rock sheet midden....................... 3

Figure 1-4. 1980 Feature 3. Plan view at $70 \mathrm{cmbs}$ atop feature and $80 \mathrm{cmbs}$ surrounding feature. ................................. 4

Figure 2-1. Location of the project area relative to the vegetation regions of Texas....................................................... 7

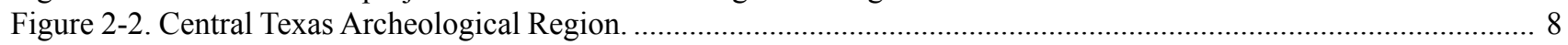

Figure 2-3. Cordova Creek downstream of FM 306 crossing. Note ponding along limestone bottom. ........................... 10

Figure 2-4. Cordova Creek south of site. Note dry streambed with erosional limestone cobbles. .................................. 10

Figure 2-5. Eminence of spring in the dry Cordova Creek bottom, $200 \mathrm{~m}$ upstream from mouth. .................................. 11

Figure 2-6. Final reach of Cordova Creek near mouth. Note rapid flow. ................................................................ 11

Figure 2-7. Present-day confluence of Cordova Creek and Guadalupe River. ........................................................... 12

Figure 2-8. Poaceae pollen percentages for Patschke and Boriack bogs. .................................................................. 13

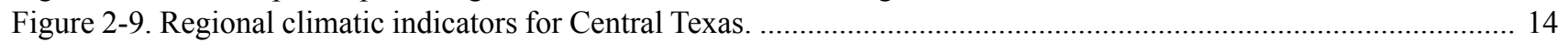

Figure 3-1. Comparative cultural chronologies of Central and South Texas. ............................................................... 18

Figure 5-1. 1980 Excavation Unit 8 (N80/E200) at bottom of Level 10 .............................................................. 24

Figure 5-2. Location of 2002 excavation units in relation to 1980 excavation units.................................................... 25

Figure 6-1. Site map in relation to surrounding geographic features......................................................................... 30

Figure 6-2. Detailed soil-stratigraphic profiles from backhoe localities and schematic alluvial stratigraphic

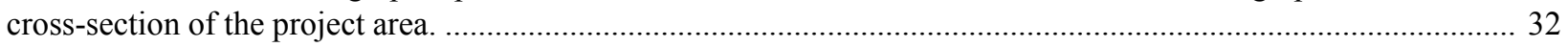

Figure 6-3. Geomorphic map projecting locations of EH and LH meander belts and alluvium. ................................... 34

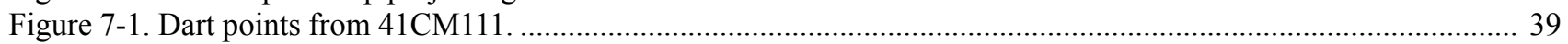

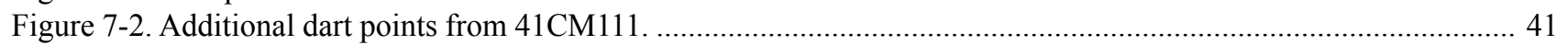

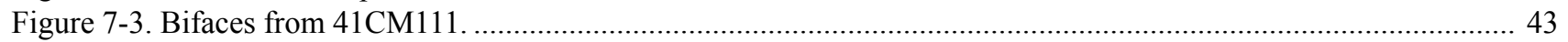

Figure 7-4. Distribution of corticate debitage by level within units N80/E200 and N106/E200 ............................... 47

Figure 7-5. Distribution of biface thinning flakes by level within units N80/E200 and N106/E200 ........................... 48

Figure 7-6. Plan view of Feature 7 in Unit 23, 41CM111. ....................................................................................... 49

Figure 7-7. Feature 7 in north wall profile of Backhoe Trench 2, 41CM111.............................................................. 50

Figure 7-8. Photograph of 1980 main excavation block at the bottom of Level $8(80 \mathrm{cmbs})$...................................... 51

Figure 8-1. South wall profile of Unit 20, 2002 excavations at 41CM111................................................................. 56

Figure 8-2. North wall profile of Unit 21, 2002 excavations at 41CM111............................................................... 56

Figure 8-3. North wall profile of main excavation block north of FM 306, 1980 excavations at 41CM111 .................... 56

Figure 8-4. Views of two biface thinning flakes removed in sequence and refitted. ........................................................ 58

Figure 8-5. Views of three corticate flakes from a stream-rolled cobble removed in sequence and refitted. .................... 59

Figure 8-6. Distribution of magnetic sediment susceptibility values by depth below surface (cmbs) in Unit 21............. 60

Figure 8-7. Distribution of diagnostic projectile points in block excavation with radiocarbon dated surfaces................. 68 


\section{Tables:}

Table 6-1. Beta Analytic, Inc. results of radiocarbon dating for samples recovered from 41CM111 ................................... 31

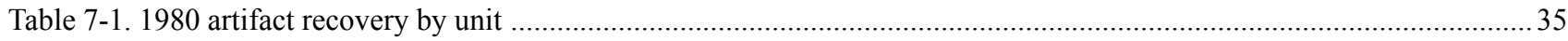

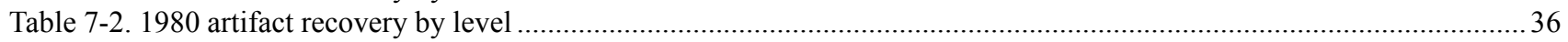

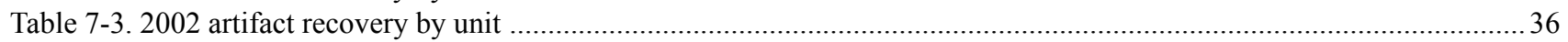

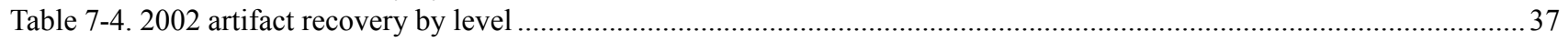

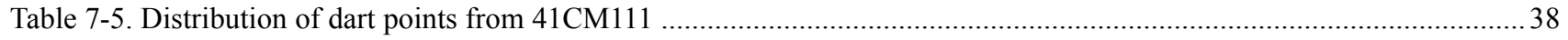

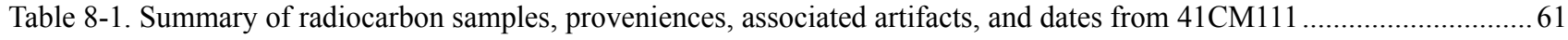

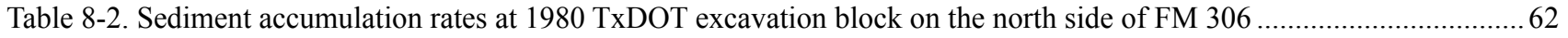

Table 9-1. Breakdown of midden and feature types within sites consulted in literature survey ................................................8 80

Table C-1. Magnetic sediment susceptibility data for a variety of substances .................................................................. 123

Table C-2. Presence/absence of cultural material and sediment susceptibility scores for shovel tests at 41BR473 ................ 124

Table C-3. Magnetic susceptibility values for the 10 samples from Unit 21, 41CM111 .............................................. 124 


\section{Acknowledgments:}

Over the span of three decades, numerous individuals were instrumental in the successful completion of this project. To all of the following, a hearty thank you is extended from the authors.

The 1980 SDHPT field crew members included Wayne Belyeu, Doug Comstock, Glen Davis, Edwin Dunn, Kathryn Kolbe, Anthony Lee, Clive Luke (Project Archeologist), Manuel Peregrino, and Wayne Young. Around 1986, Alan Wormser reviewed a portion of the artifacts and associated documents in the SDHPT Archeology Laboratory.

Current TxDOT employees who assisted in the investigations include Jim Abbott and Al McGraw of the Environmental Division, Austin. Barrlynn West of the San Antonio District was instrumental in coordinating logistics. In the field, Rick Hanks and Robert Scheel of the New Braunfels Area Office were most helpful.

The 2002 CAR field crew consisted of Mike Fulghum (Backhoe Operator), Rich Mahoney (Project Archeologist), Bruce Moses (TDS Operator), Rick Robinson, Bryant Saner, Matthew Senn, and Jason Weston. Raymond Mauldin served as Principal Investigator.

The CAR laboratory staff included Rebecca Galdeano (Laboratory Project Director), Cindy Muñoz, Rick Robinson, Amy Rose, Marybeth Tomka (Laboratory Supervisor and Collections Manager), and Stacy Wagner.

Bruce Moses and Rick Young of CAR drafted the illustrations in the report, while Johanna Hunziker, CAR editor, produced this final report. CAR administrative support staff included Tammy Hosek (Senior Secretary), Sherrilyn Suñaz (Administrative Coordinator), and Mike Wright (Accountant). 
This page has been

redacted because it

contains restricted

information. 


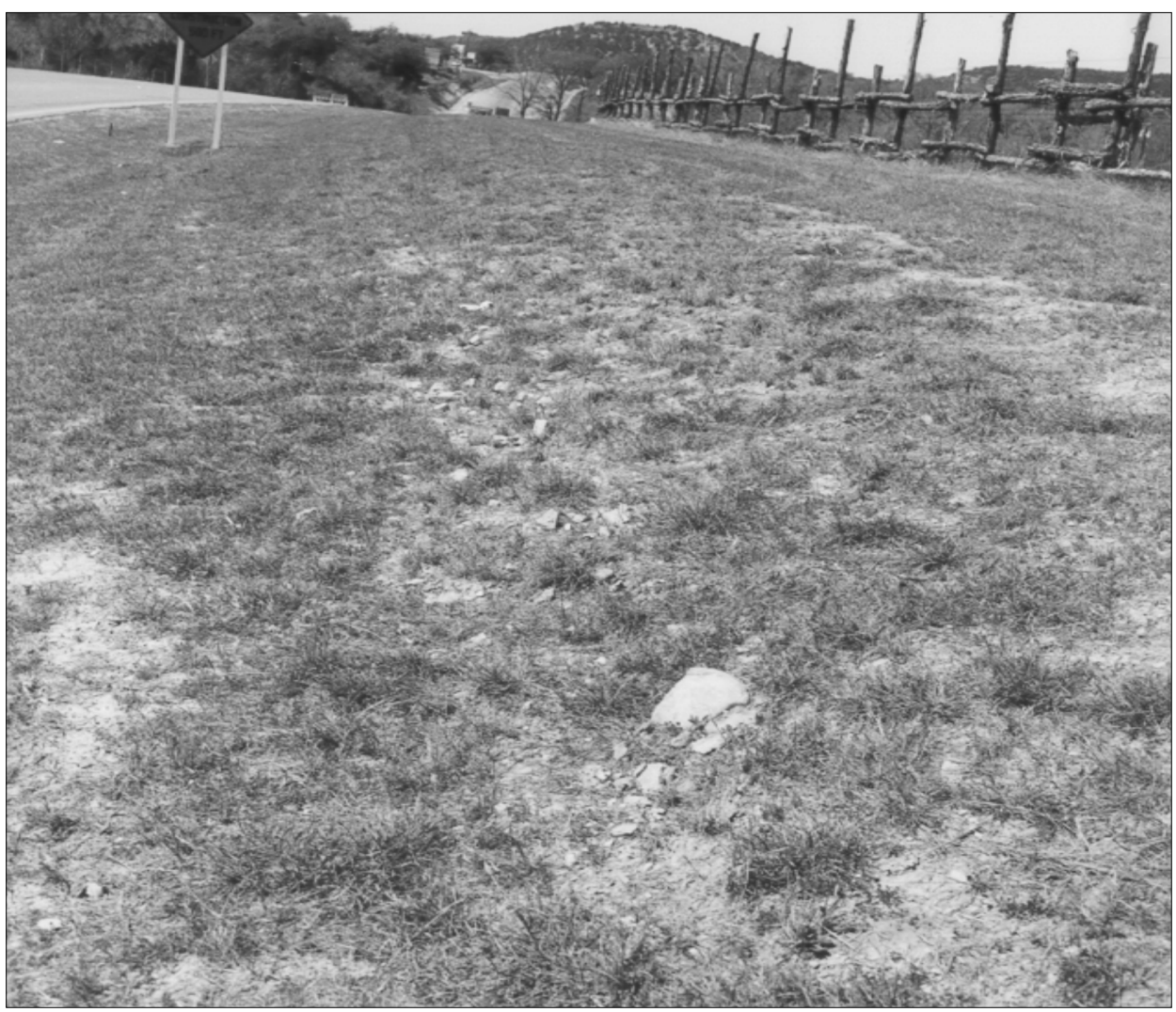

Figure 1-2. View of surface scatter along north side of FM 306 prior to 1980 excavations.

the block reached the burned rock layer, however, it became clear that the materials represented a portion of a burned rock sheet midden. We use the term sheet midden to refer to an amorphous, moderate to lowdensity distribution of burned rock consisting mainly of secondary deposits of burned rock combined with burned rock from disturbed features and few, if any, in situ features. While the majority of the burned rock in the sheet midden had no apparent recognizable patterning, a single feature (Feature 3), a circular arrangement of burned rock (Figure 1-4), appears to represent an in situ rock-lined hearth among the seemingly random scatter of burned limestone rocks (see also Figure 1-3).

While the excavations yielded a mix of Early and Middle Archaic projectile points and identified an extensive depositional/living surface, the geomorphic context of the site remained poorly understood and the prehistoric occupations of the site remained undated. In 2001, TxDOT contracted with the Center for Archaeological Research (CAR), The University of Texas San Antonio to perform a thorough appraisal of the artifactual and ecofactual materials and documents derived from the TxDOT work.

The resulting assessment (Mahoney 2001) indicated that Nolan and Early Triangular projectile points tended to occur in roughly the same stratigraphic contexts. In addition, it became evident that detailed information on the geomorphic context of the site may aid in the overall interpretation of the integrity of the cultural materials recovered during the previous fieldwork. The assessment of the site also indicated that additional datable materials would be useful to determine the age and chronological relationship between the components identified by temporal diagnostic artifacts. Finally, it became evident that additional features needed to be excavated in an attempt to clarify the nature of the burned rock sheet midden identified in the previous excavations. 


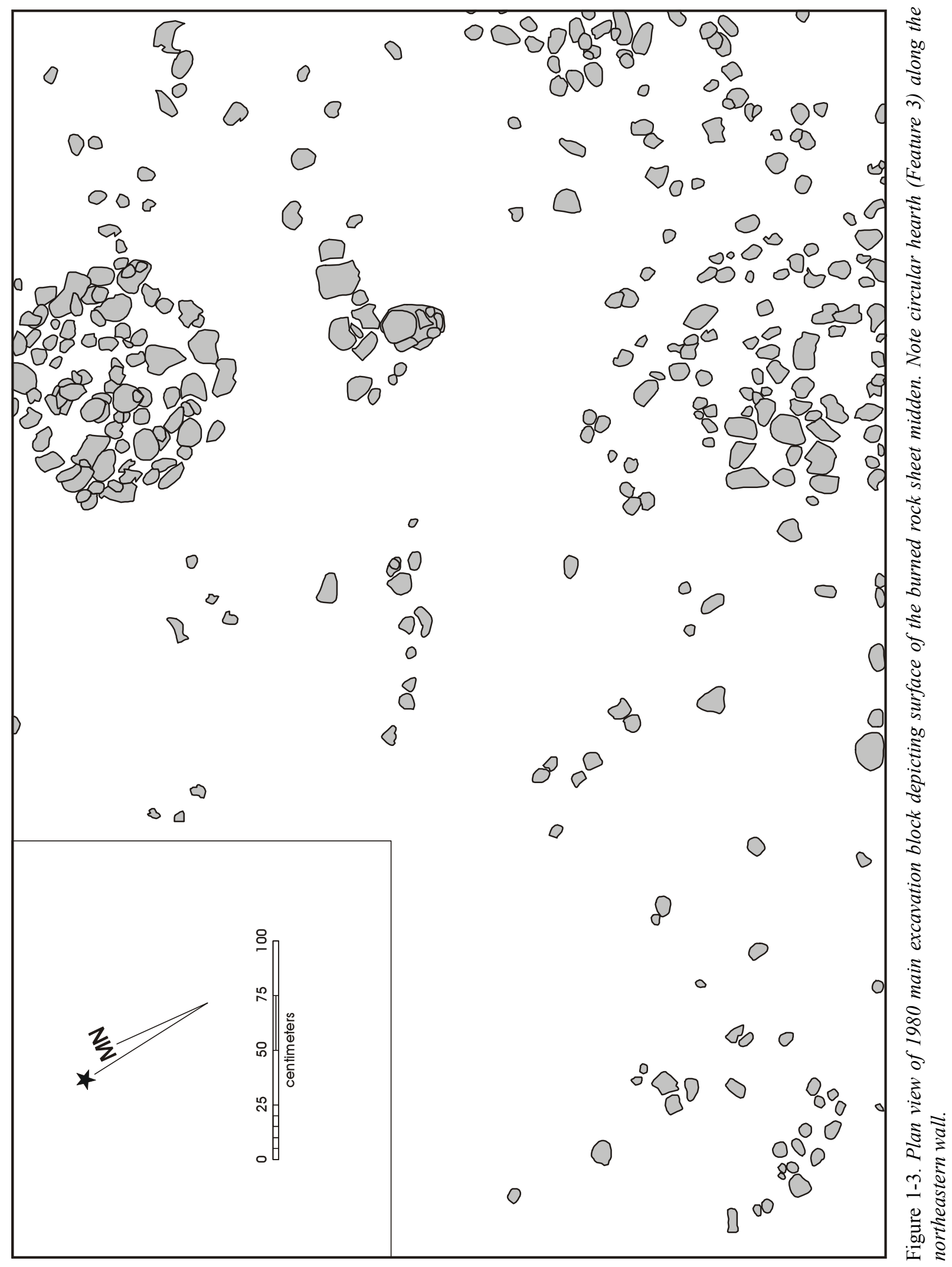


Consequently, TxDOT awarded a second contract to CAR to perform additional, complementary excavations at the site. These supplementary investigations were to augment the initial field efforts through a combination of mechanical and manual excavations. The proposed mechanical excavations were primarily intended to address the geomorphological setting of the site within the Guadalupe River valley. The additional manual excavations sought to recover in situ datable materials such as charcoal or other charred remains to date the occupation(s) associated with the formation of the burned rock sheet midden. The excavations also were to recover a series of additional special samples such as magnetic sediment susceptibility samples, terrestrial snail shells, soil samples for macrobotanical flotation, and charcoal samples for wood fuel identification to broaden the evidence available to reconstruct site occupation history.

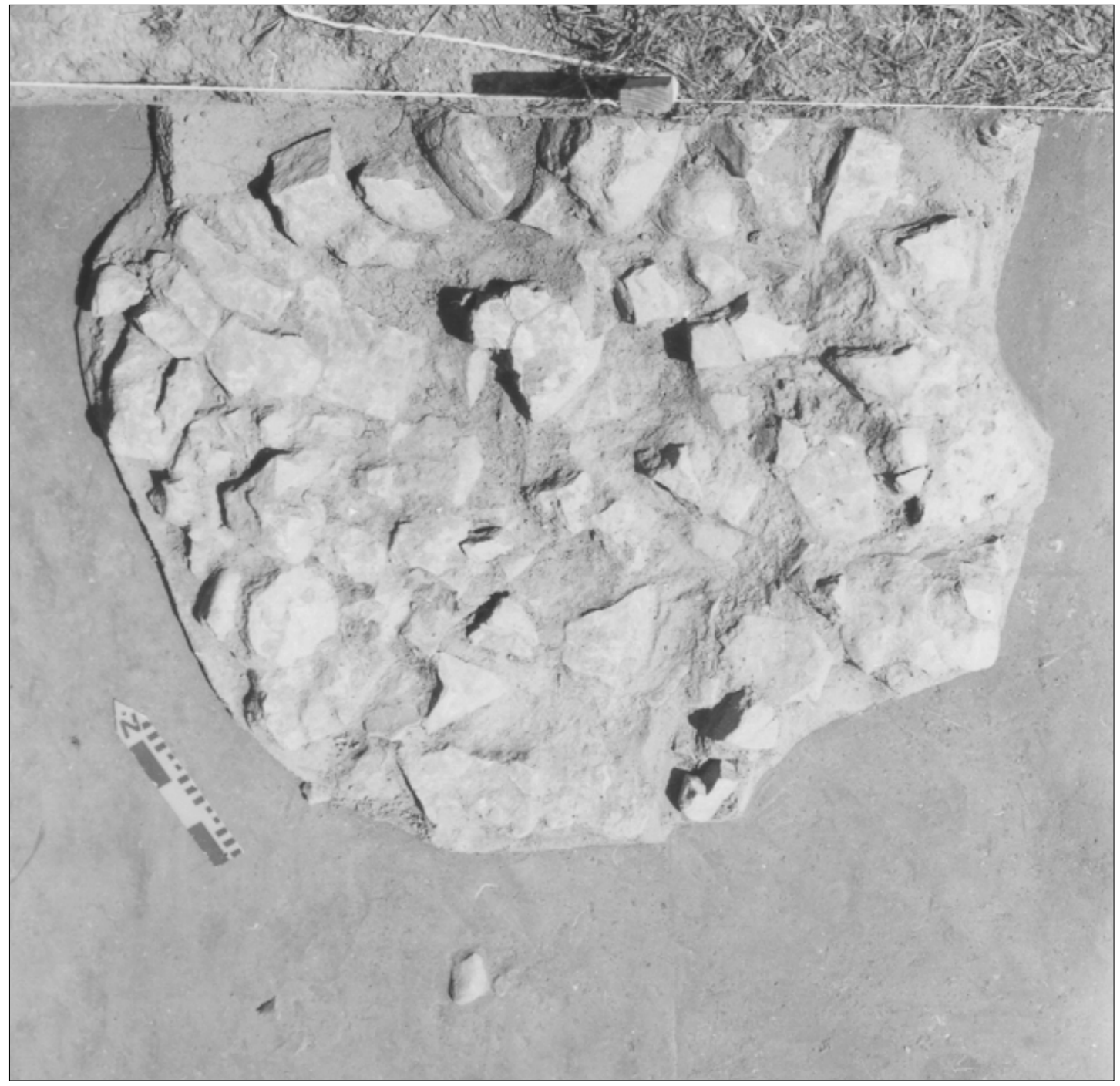

Figure 1-4. 1980 Feature 3. Plan view at $70 \mathrm{cmbs}$ atop feature and $80 \mathrm{cmbs}$ surrounding feature. 


\section{Report Layout}

This report is divided into eleven chapters and three appendices. Following this introduction, Chapter 2, Environmental Setting, briefly discusses the general physical environment of the project area. The third chapter, Archeological Background, provides a project history and an overview of the relevant cultural setting of the region. Chapter 4 discusses the general theoretical background and specific research modules that represent the foci of this report. Chapter 5, Field and Laboratory Methods, describes in detail the field methodology employed during the investigations. Chapter 6, Geoarcheology, presents the results of the geomorphic investigations performed at 41CM111. The seventh chapter, Results of Investigations, summarizes the materials recovered from the 1980 TxDOT and 2002 CAR field investigations and presents the feature descriptions. Chapter 8, Site Integrity and Chronology, discusses the stratigraphic integrity of the deposits and the age of the cultural materials based on the radiocarbon dates and the temporally diagnostic artifacts. Chapter 9 , Burned Rock Features, discusses the nature of the burned rock sheet midden identified at 41CM111 and the processes and geomorphic factors that may have contributed to its formation. Within this chapter, relationship of the sheet midden to other types of burned rock features is considered and the difficulties inherent in using it as a temporal indicator of Early/Middle Archaic occupations are discussed. Chapter 10, Early Middle Archaic Lithic Assemblages, considers the mixture of temporal diagnostic projectile points recovered from the site and relates them to the processes that may have also contributed to the formation of the burned rock sheet midden present on the site. The eleventh and final chapter, Summary and Conclusions, provides conclusions derived from both the TxDOT and CAR investigations. Appendix A contains the geomorphic soil-stratigraphic descriptions, Appendix B presents the results of the radiometric dating of 41CM111, and Appendix C presents the results of the magnetic sediment susceptibility analysis. 



\section{Chapter 2: $\quad$ Environmental Setting}

Steve A. Tomka, Richard B. Mahoney, and Raymond P. Mauldin

\section{Introduction}

This chapter presents a summary of the environment of the Guadalupe River valley region to provide a background for the interpretation of prehistoric and historic human adaptations to the eastern margin of the Edwards Plateau vegetation region (Figure 2-1).

The Guadalupe River proper heads in the central portion of Kerr County, west of the county seat, Kerrville. The river is formed from two smaller streams, the North Fork of the Guadalupe and the South Fork of the Guadalupe, both of which head in the western portion of Kerr County.
Throughout its upper reach, the stream proper drains the Edwards Plateau of Kerr, Kendall, and Comal counties. In the southeastern portion of Comal County, the Guadalupe flows across the Balcones Escarpment and out onto the Blackland Prairie. From this point, the stream trends in a southeasterly path across the West Gulf Coastal Plain through Guadalupe, Gonzales, DeWitt, and Victoria counties where it empties into San Antonio Bay.

The Royal Coachman site is located in the northeastern portion of Comal County along the left descending bankline of the Guadalupe River near its present-day confluence with Cordova Creek. This portion of the

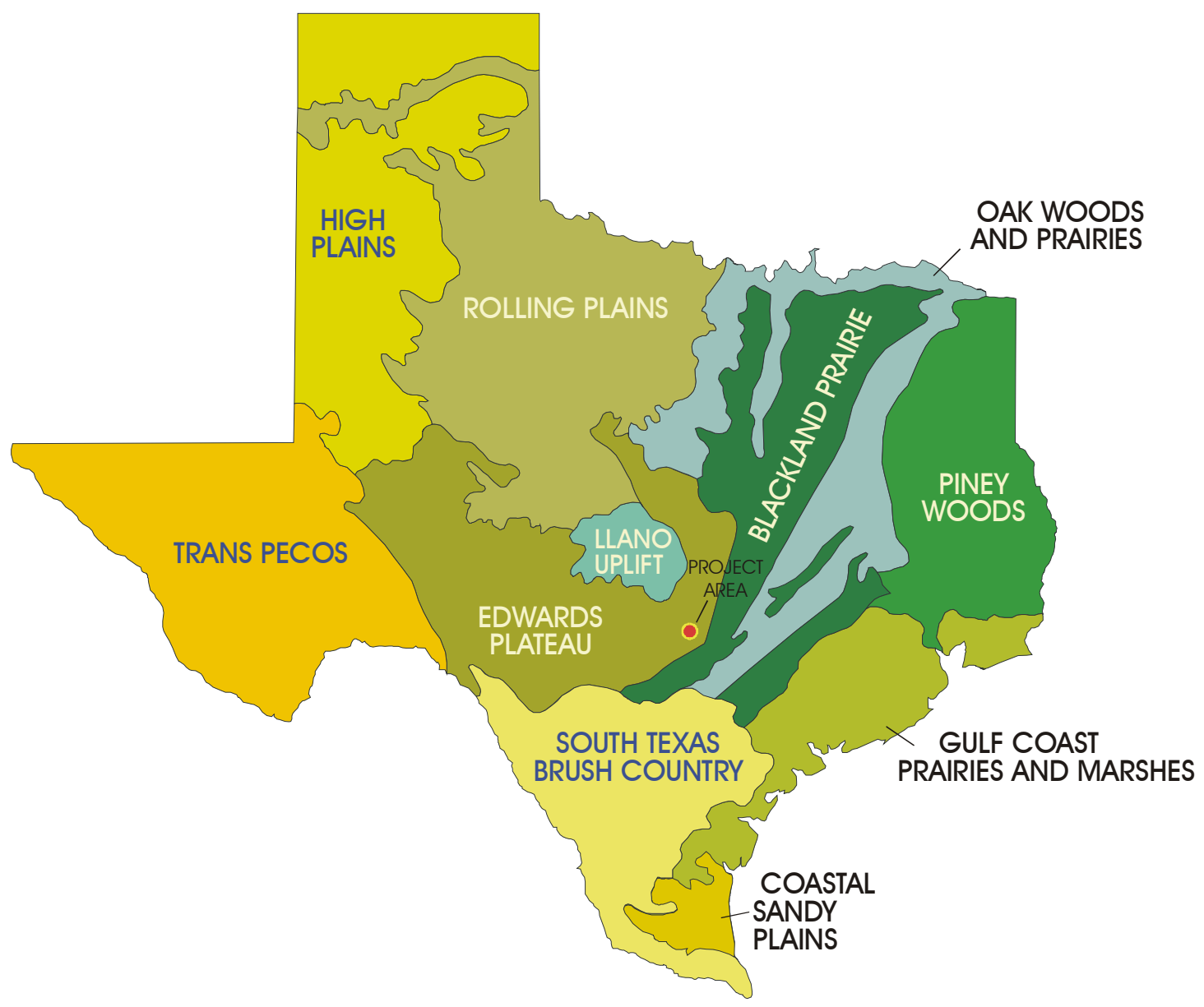

Figure 2-1. Location of the project area relative to the vegetation regions of Texas. 
county falls along the extreme eastern boundary of the Edwards Plateau in the southeastern corner of the Central Texas Archeological Region (Figure 2-2). The site is located at roughly $765 \mathrm{ft}(233 \mathrm{~m})$ AMSL, with elevations in the immediate vicinity of the project area ranging from $740 \mathrm{ft}(226 \mathrm{~m})$ in the stream valleys to $1,150 \mathrm{ft}(351 \mathrm{~m})$ atop the associated peaks. Situated at the toe of an interfluviatile upland ridge between Heiser and Cordova Hollows, these environs would have been an attractive landform for the prehistoric inhabitants of $41 \mathrm{CM} 111$.
Comal County has a subtropical climate, with relatively mild winters and hot summers. The average low temperature for January is $37^{\circ} \mathrm{F}\left(4^{\circ} \mathrm{C}\right)$ and the average high temperature for August is $97^{\circ} \mathrm{F}\left(36^{\circ} \mathrm{C}\right)$. The average length of the growing season is roughly 270 days a year, and the region seldom experiences hard freezes. The prevailing winds are light ( $<10$ knots) and predominately blow from the southeast. The average annual precipitation is 33 inches $(85 \mathrm{~cm})$, with primary peaks of rainfall occurring during the months of May and September (Batte 1984:96).

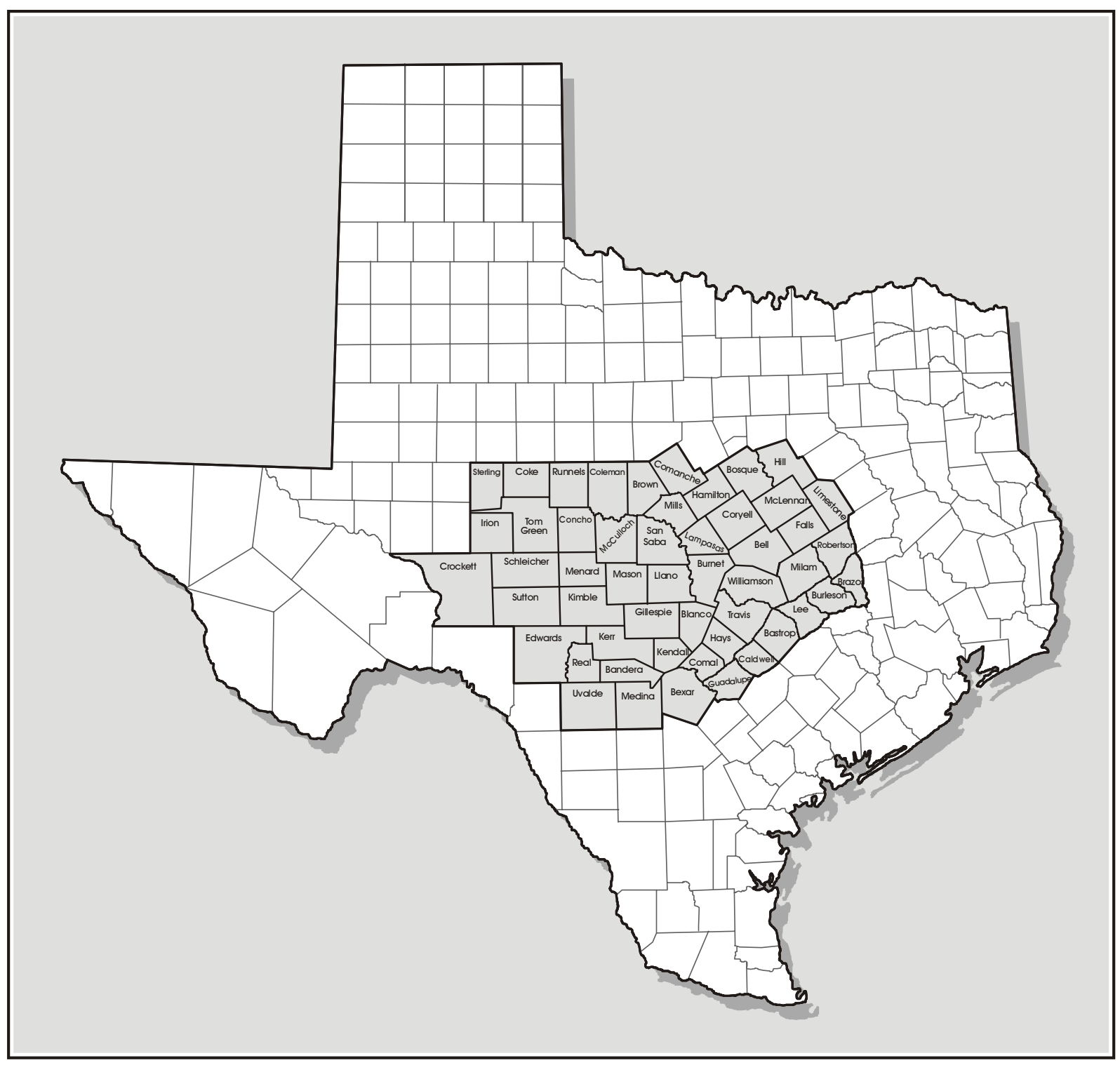

Figure 2-2. Central Texas Archeological Region. 
Data from Canyon Dam, located roughly four kilometers from the site, mirrors these county-wide patterns in general detail. Between 1971 and 2000, rainfall at Canyon Dam averaged 36.46 inches $(93 \mathrm{~cm})$ per year, with peaks occurring in the months of May (4.6 inches [12 cm]), June (4.43 inches [11 cm]), and October (4.13 inches $[10 \mathrm{~cm}])$. The driest months at Canyon Dam were January, with an average of 2.01 inches $(5 \mathrm{~cm})$, and February, with only 1.97 inches $(5 \mathrm{~cm})$ of precipitation (Southern Regional Climate Center [SRCC] 2003a). Maximum average monthly temperatures peaked at $95^{\circ} \mathrm{F}$ $\left(35^{\circ} \mathrm{C}\right)$ in August (SRCC 2003b) with an average minimum monthly temperature of $37.6^{\circ} \mathrm{F}\left(3.1^{\circ} \mathrm{C}\right)$ occurring in January (SRCC 2003c).

The project area lies within the Balconian biotic region of Texas, a region characterized by an amalgamation of faunal species from surrounding biotic provinces, yet with its own distinctive floral community (Blair 1950). Site 41CM111 is situated in the Hill Country, or Balcones Canyonlands region, characterized by the dissected margins of the Edwards Plateau. Numerous, highly dependable springs, fed by the deep water table of the Edwards Aquifer, were present in this area during historic times (Brune 1975). Increased agricultural activities, ranching, and industrial practices brought on by European settlement have dramatically decreased ground water availability and diminished discharge from these springs.

Modern vegetation within the project area predominately consists of evergreen woodlands atop the associated uplands and a mixed evergreen and deciduous forest within the valleys and riparian zones along streams. The present biota is the product of centuries of historic land use including grazing and agriculture.

The published soil series for the project area is mapped as Boerne fine sandy loam (Batte 1984:Sheet 70), with the soils comprising the floodplains and terraces of the Guadalupe River. The adjacent upland consists of the Brackett-Rock outcrop of well-drained, steep loamy soils (Batte 1984:68). On a broader scale, the published geologic unit for the project area includes Holocene fluviatile terrace deposits adjacent steep West Nueces Formation (limestone) of the Lower Cretaceous (Bureau of Economic Geology 1983). These fluviatile terrace deposits typically provide a rich source of knappable raw materials.
Natural outcroppings of chert occur along the Balcones Escarpment within the limestone formations characteristic of this landform. A thorough reconnaissance of the formation adjacent the site, however, failed to locate any stringers of chert within the massive limestone strata. According to local residents, though, similar landforms associated with Heiser Hollow to the north are purported to possess large amounts of chert with apparent evidence of quarrying activities. The overland distance to these landforms from 41CM111 is approximately $500 \mathrm{~m}(1,640$ $\mathrm{ft})$. Given that no chert was noted within the gravels of the creeks in the vicinity of the site, this distance may have been sufficiently large enough to affect the lithic procurement strategies employed by the site's inhabitants (see Chapter 7).

Cordova Creek is an intermittent stream draining a relatively short hollow (Cordova Hollow) and winds approximately $5 \mathrm{~km}(3 \mathrm{mi})$ from head to mouth. Reference to recent USGS quadrangle maps shows a gravel pit just upstream from the site. A brief reconnaissance of the stream in the vicinity of the site and toward the confluence with the Guadalupe River reveals a few areas of ponding (Figure 2-3) along a predominantly dry stream (Figure 2-4). However, a small spring occurs roughly $200 \mathrm{~m}(656 \mathrm{ft})$ upstream of the mouth (Figure 2-5). The spring flow provides a steady current of water (Figure 2-6) that continues along the final $200 \mathrm{~m}(656 \mathrm{ft})$ of the stream, emptying into the Guadalupe River (Figure 2-7).

\section{Regional Paleoenvironment}

Given that paleoenvironmental information from the immediate vicinity of $41 \mathrm{CM} 111$ does not exist, this section briefly reviews a number of regional paleoenvironmental data sources. A number of different data sets are used (including pollen, phytolith, geomorphic, oxygen-isotope, and faunal data) in an attempt to document aspects of the paleoenvironment from the close of the Pleistocene until roughly $4000 \mathrm{BP}$, the end of the Middle Holocene and a date exceeding the principal welldated occupation of the site. Each of these data sets monitors climate and vegetation changes at varying spatial and temporal scales. In addition, each data set has specific problems associated with preservation, sampling, chronological control, and interpretation. A review of the problems and prospects associated with 


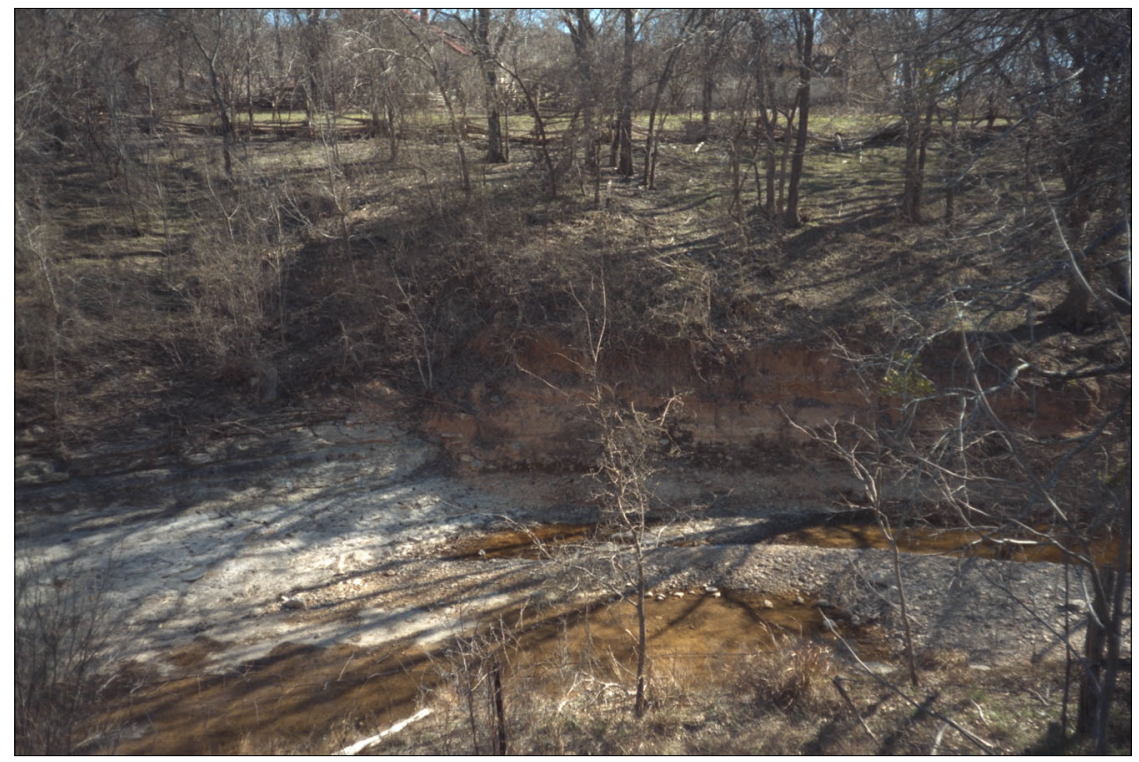

Figure 2-3. Cordova Creek downstream of FM 306 crossing. Note ponding along limestone bottom.

each specific data set is beyond the scope of this section, and several excellent discussions are available (e.g., Bousman 1998; Collins 1995; Hall and Valastro 1995; Johnson 1995; Johnson and Goode 1994).

\section{Late Pleistocene}

$$
\text { (ca. 18,000-10,000 BP) }
$$

One of the most useful data sets for paleoenvironmental research is found in pollen. Pollen studies have a relatively long history in Texas (see Potzger and Tharp 1943, 1947) and a variety of different sequences, primarily derived from bogs, have been gathered and analyzed (see Bryant 1977; Graham and Heimsch 1960; Holloway and Bryant 1984; Larsen et al. 1972; Potzger and Tharp 1943, 1954). The best-dated sequences are from two bogs, Boriack and Patschke, located in Lee County. These bogs are roughly $135 \mathrm{~km}(84 \mathrm{mi})$ to the east of 41CM111. For the Late Pleistocene, the pollen sequence from Boriack Bog suggests a shift from grasslands before 16,500 BP to woodlands limestone cobbles. View is to the east. before 12,500 BP in a moist and cool climate (Bousman 1994:79). The same spectra reveal a decline in coldadapted spruce pollen by $15,000 \mathrm{BP}$, indicating a trend toward a warmer climate. Bousman's (1992) oxygenisotope evidence from South Texas complements the bog pollen data and suggests early warming by $15,000 \mathrm{BP}$. Between 12,500 and 11,800 BP, the Boriack Bog data indicate that a drier episode stimulated a brief shift to grasslands, corroborated by oxygenisotope ratios showing a cooler setting in South Texas (Bousman 1992, 1994:80).

Recently, Camper (1991) has reanalyzed the Patschke Bog data that was originally investigated by Potzger and Tharp $(1943,1947)$ and later by Bousman (1994, 1998). As summarized by Nickels and Mauldin (2001:34-35), the samples presented by Camper appear to represent a continuous and relatively well-dated sequence stretching back to $17,000 \mathrm{BP}$. However, as Bousman (1998:207-208) notes, the Patschke data have significant frequencies of local marsh taxa, such as alder (Alnus) and Cyperaceae, which make the identification

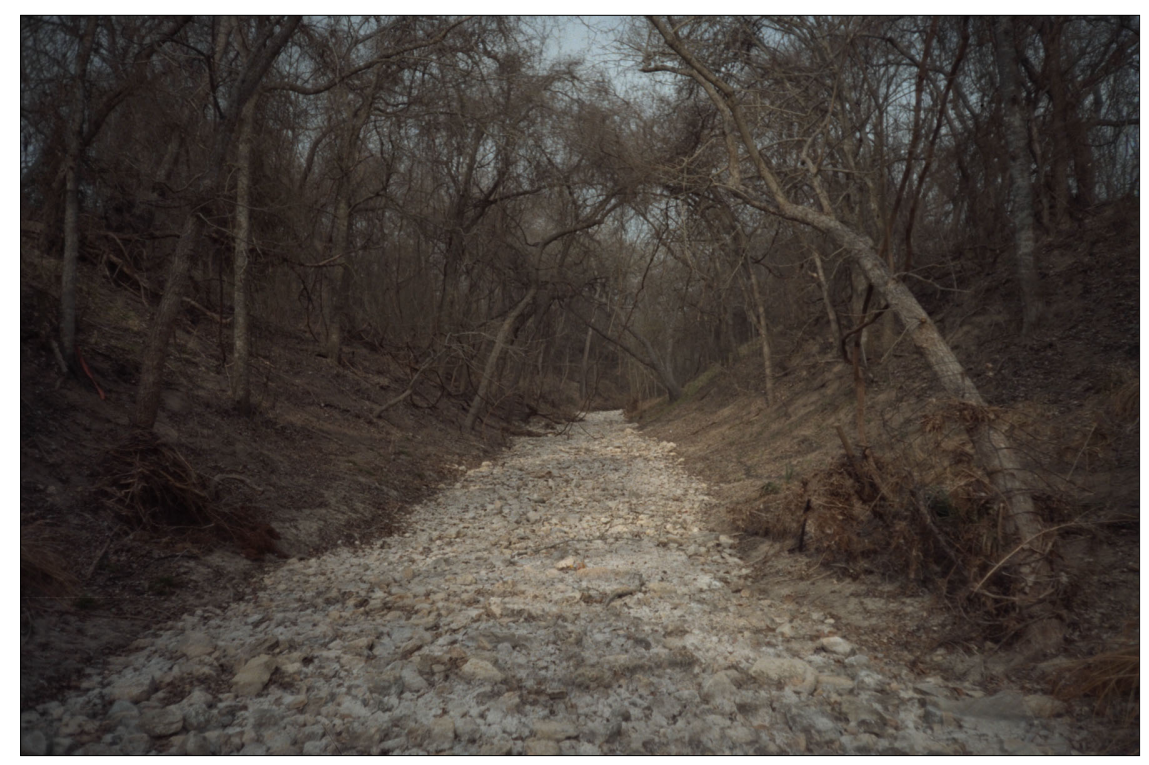

Figure 2-4. Cordova Creek south of site. Note dry streambed with erosional 
of regional changes difficult. In an attempt to clarify the pattern of regional change indicated at Patschke Bog, Nickels and Mauldin (2001) reviewed the raw pollen grain counts from Patschke Bog (Camper 1991). While Bousman (1998) is correct in noting the high level of marsh taxa throughout the deposits, it appears that Camper's grain counts, unavailable to Bousman in 1998, are extremely high. Average counts are just over 370 grains per level, and none of the 51 separate levels has a count lower than 270. Nickels and Mauldin (2001) eliminated the marsh taxa pollen for Patschke Bog, an exercise that results in an average sample size of just over 215 grains per level with more than 50 percent

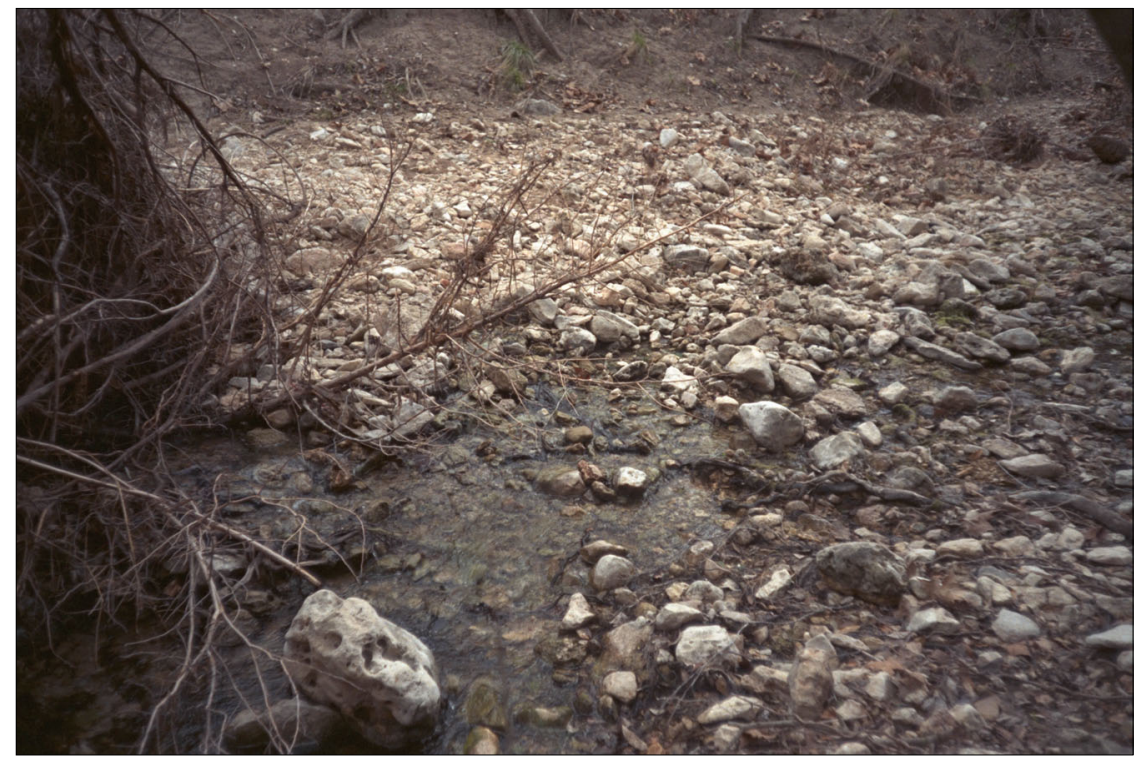

Figure 2-5. Eminence of spring in the dry Cordova Creek bottom, 200 m upstream from mouth. of the levels having sample sizes above 200. Only in three cases do the revised counts drop below a sample of 100 grains, and in each of these cases, the overall pattern revealed by the low sample levels is supported by adjacent levels with higher frequencies.

Figure 2-8, adapted from Nickels and Mauldin (2001:35), lists the revised percentages for grass (Poaceae) taxa for Patschke Bog, as well as the grass percentages for

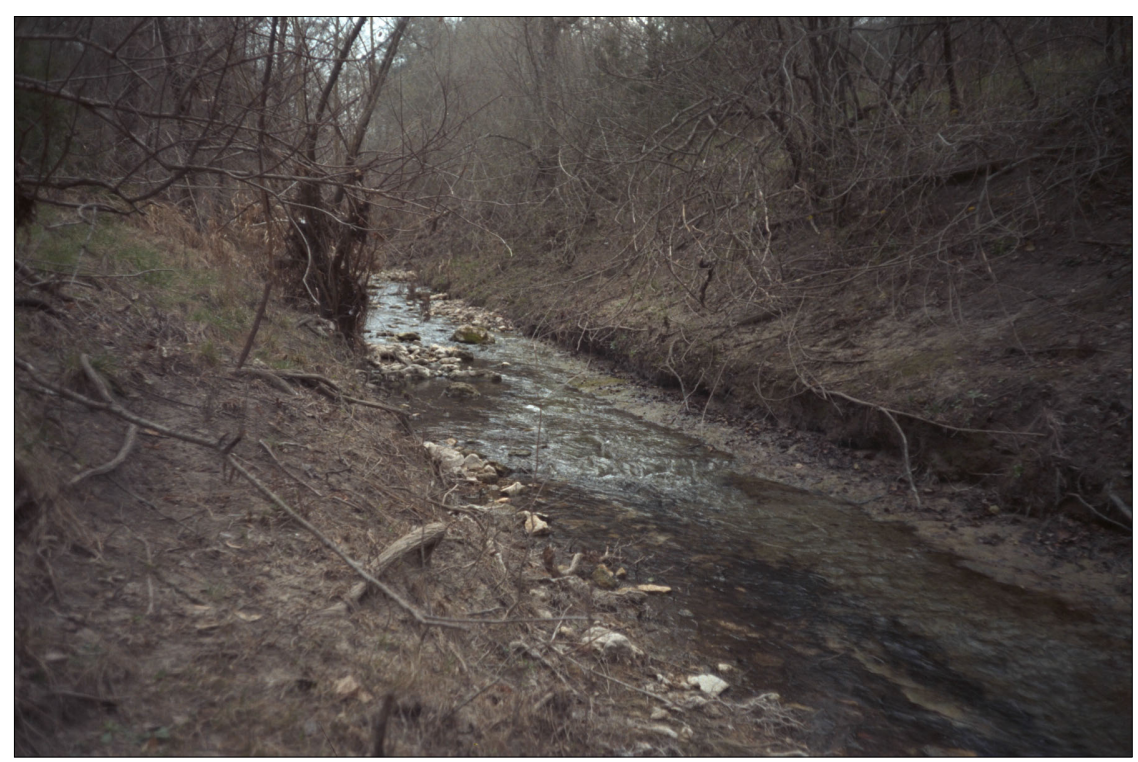

Figure 2-6. Final reach of Cordova Creek near mouth. Note rapid flow.
Boriack Bog with major contaminants removed (Bousman 1998), for the period of interest. An examination of the figure shows good correlation with Bousman's (1998) summary, especially in light of the fact that the dating of the sediment core analyzed from Boriack Bog (Core 1) is based on four radiocarbon dates from an adjacent core (see Nickels and Mauldin 2001:34-35). The Patschke Core 4 samples are supported by four radiocarbon dates from that core, and by additional dates from Core 2 located less than two yards away from Core 4 (Camper 1991:31).

When considered together, the Patschke and Boriack pollen sequences (Figure 2-8) provide the best evidence for pollen-based paleoclimate reconstruction in the region. For the close of the Pleistocene, these two sequences suggest that between roughly 17,000 $\mathrm{BP}$ and $15,500 \mathrm{BP}$, a cool grassland environment may have been present. After $15,500 \mathrm{BP}$, a rapid decline is indicated which reaches a low at roughly $14,000 \mathrm{BP}$ in the Patschke sequence, and slightly earlier in the Boriack sequence. While there is a 


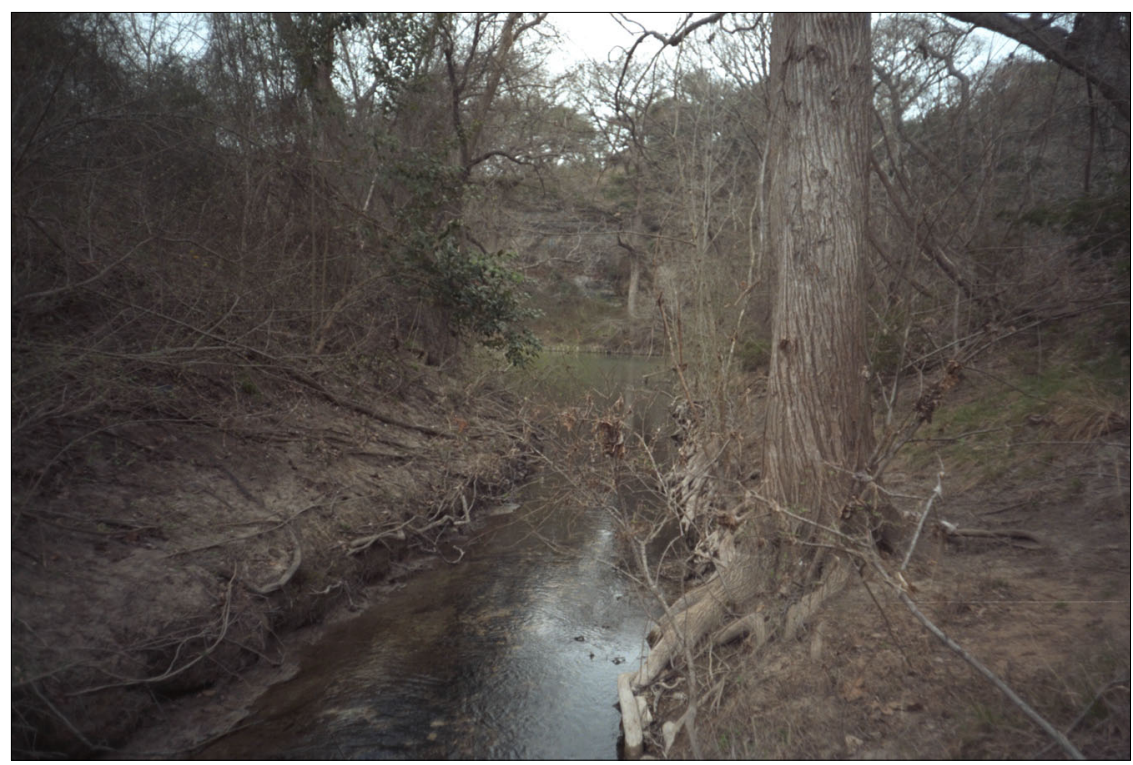

Figure 2-7. Present-day confluence of Cordova Creek and Guadalupe River.

brief spike in grass percentages between about 13,200 and $12,000 \mathrm{BP}$, possibly indicating a warmer or more arid interval, low grass frequencies are present until roughly 10,000 BP. Though not shown in Figure 2-8, Nickels and Mauldin (2001) note that pollen from coldadapted arboreal species such as spruce (Picea) are not present in the Patschke sequence after about 8000 BP, and are not frequent after the Late Pleistocene. These data are consistent with a general warming trend throughout this period.

Toomey (1993; see also Toomey et al. 1993) argues that microfaunal material from Hall's Cave, located roughly $100 \mathrm{~km}$ to the west of $41 \mathrm{CM} 111$, suggests that summer temperatures in the Late Pleistocene were $6^{\circ} \mathrm{C}$ cooler than present averages, and that by around 13,000 $\mathrm{BP}$, the wetter interval became warm and more arid. This warmer period correlates nicely with that suggested by the pollen sequences summarized here. The Hall's Cave record indicates a wetter interval is again present at the close of the Pleistocene (Toomey and Stafford 1994), a pattern consistent with the picture presented by the pollen record.

\section{Early and Middle Holocene (ca. 10,000-4000 BP)}

A variety of different data sets indicate a gradual and consistent warming trend throughout the Early Holocene and continuing into the Middle Holocene. This increasing warmth is clearly indicated in Figure 2-8. During much of this period, both the Patschke and Boriack spectra show a consistent increase in grass pollen. The Early Holocene, and much of the Middle Holocene, saw a continuous decline of woodland environments.

This decline was briefly checked sometime around 5000 to $6000 \mathrm{BP}$, but resumed its slide until late in the Middle Holocene when arboreal pollen slowly increased with the appearance of a wetter climate (Bousman 1994:80). This pollen based scenario agrees with data presented by Nordt et al. (1994) from the Applewhite project, located roughly $80 \mathrm{~km}(50 \mathrm{mi})$ to the south of $41 \mathrm{CM} 111$. There, a dry period for roughly the same time frame (6000-4800 BP) is indicated. Humphrey and Ferring (1994) discovered the same arid episode in north-central Texas, but with greater duration (6500-4000 BP), 


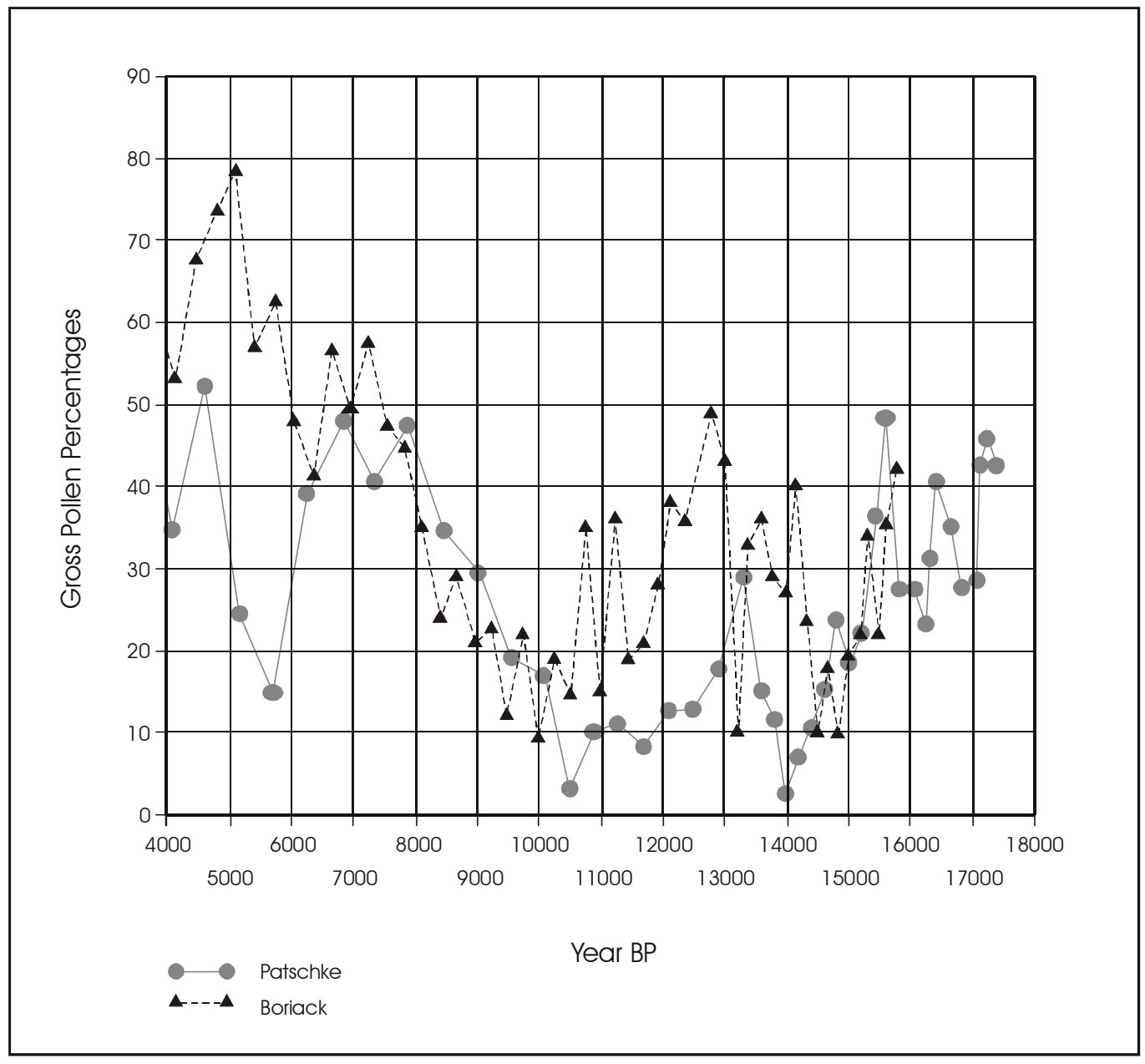

Figure 2-8. Poaceae pollen percentages for Patschke and Boriack bogs.

agreeing with the revised interpretation from Hall's Cave for an arid episode sometime between 7000 and 2500 BP (Toomey and Stafford 1994). The same warming and perhaps drying is also seen in the fossil microfaunal remains from Friesenhahn Cave in northwestern Bexar County. Graham (1976) suggests that a major climatic change occurred between 9140 and 4680 BP leading to the extinction of large herbivores and carnivores as well as boreal microfauna. In addition, many of the deciduous species that inhabited the region early during this period were no longer found in central Texas by the end of this shift to more seasonal climatic conditions. Johnson and Goode (1994) report a later occurrence of this arid interval, sometime between 5000 and 2500 BP (calibrated). Other parts of Johnson and Goode's (1994) reconstructions of paleoenvironmental conditions, however, do not seem to agree well with Bousman's (1998) pollen-based reconstruction (c.f. the period between 8000-6000 BP). Research at Choke Canyon, approximately $200 \mathrm{~km}(125 \mathrm{mi})$ south of 41CM111, and at Goliad County at roughly the same distance east of the site (Robinson 1979, 1982), has demonstrated a dramatic decline in arboreal forms during the Middle Holocene, while they are high in the Early Holocene. During most of the Middle Holocene there is a clear dominance of Chloridoid (short) grass phytoliths. However, a single sample from the Middle Holocene indicates an increase in tall grass phytoliths, a potential 
indicator of a period of increased moisture. Robinson (1979) dates this sample at $5000 \mathrm{BP}$, but it may actually correlate with the $6000 \mathrm{BP}$ arboreal spike at Boriack Bog and the decline in grass pollen seen at Patschke Bog around this same time (see Figure 2-8). Although, the opal phytolith records from the lower portions of the Wilson-Leonard site (Fredlund 1994) may have been affected by differential preservation, they appear to indicate a general expansion of grasslands throughout most of the Holocene (Fredlund 1998:1643-1644). This expansion appears to have begun during the Early Holocene, around $9500 \mathrm{BP}$, and continued into the Middle Holocene to around 4000 BP. Another important aspect of the Wilson-Leonard pollen record is the significant increase in the rate of grassland expansion around $8700 \mathrm{BP}$.
Overall, these data seem to indicate that the warming trend begun at the close of the Late Pleistocene continued through the Early and Middle Holocene. This warming trend also may have been accompanied by increased seasonality in climatic conditions with increasing mean temperatures during the summer, potentially coupled with decreased summer precipitation. The general warming and drying trend, in combination with increased seasonality reflected in decreased effective moisture availability during the summer months, would certainly have led to a decline in arboreal cover and would have favored more open or perhaps brushy vegetation communities, except perhaps for a relatively brief interval at approximately 5000 to $6000 \mathrm{BP}$ when arboreal species increase on the Coastal Plains and tall grasses increase in the northern portion of south Texas.

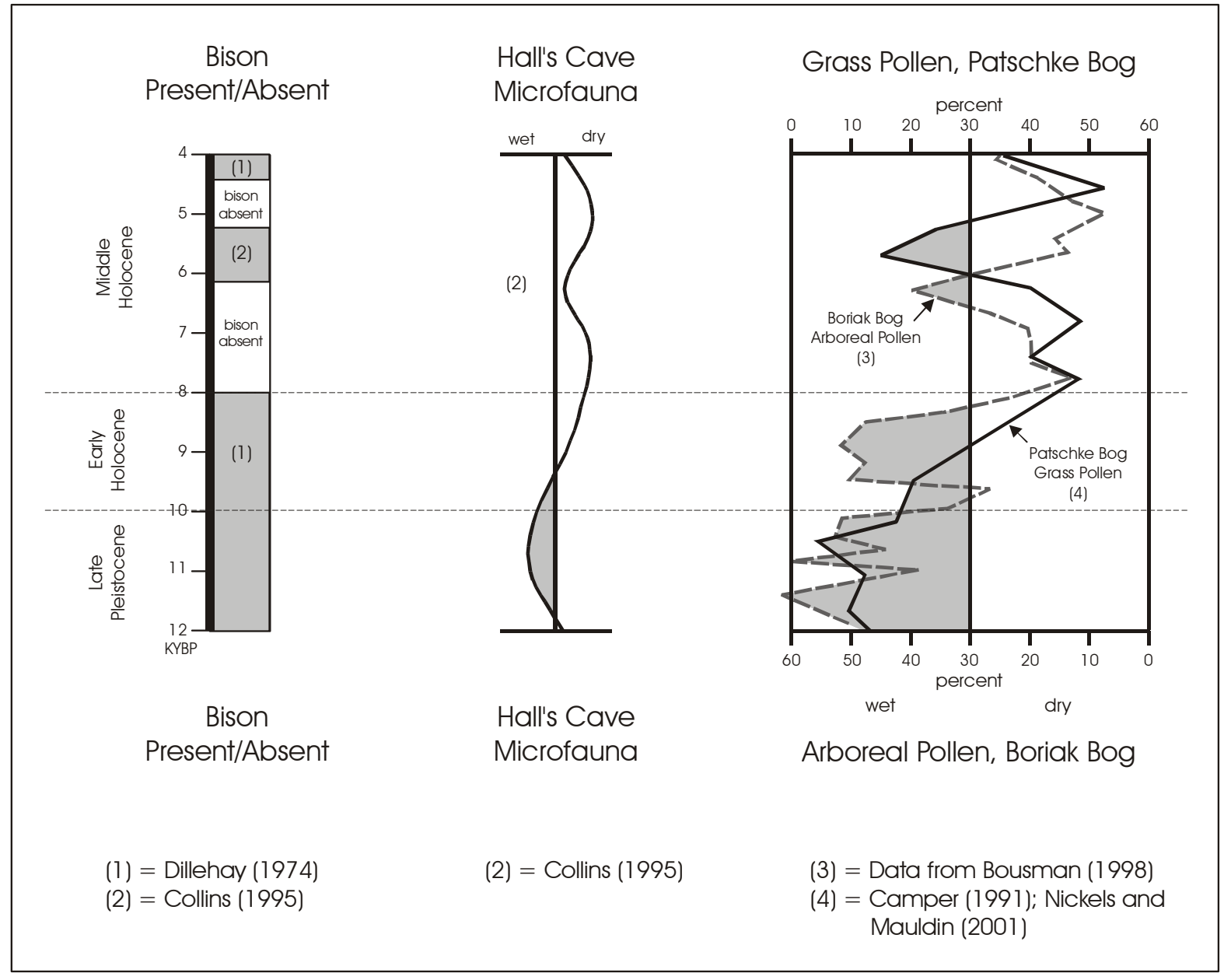

Figure 2-9. Regional climatic indicators for Central Texas. 


\section{Summary}

Figure 2-9, adapted from Nickels and Mauldin (2001:38), presents a summary of climate patterns suggested by four different data sets. The figure includes two faunal data sets as relative indicators of xeric and mesic conditions. The first data set uses Dillehay's (1974) presence/absence data for bison in the central Texas and southern plains area (see also Collins 1995; Creel et al. 1990; Hurt 1980) as well as faunal material from Hall's Cave reported by Collins (1995). In addition, two pollen data sets are used; the frequency of grass pollen taken from the revised counts at Patschke Bog (Nickels and Mauldin 2001) and the arboreal pollen frequencies taken from the second counts at Boriack Bog (Bousman 1998). While a variety of other data sets are available, these four were selected because they span the period of interest and are only reflective of two different data types, pollen and fauna.

At a general level, there is good agreement between these four different data sets. There are also periods throughout the sequence where differences are present. The waning of the Pleistocene clearly marked a transition from a cooler, wetter environment to one that steadily grew warmer and drier. All four data sets indicate that much of the Early Holocene was relatively mesic. The Middle Holocene is generally warm and/or dry, with a brief mesic period suggested sometime between 6000 and $5000 \mathrm{BP}$.

\section{Summary}

Site 41CM111 is located within the Balconian biotic region near the eastern edge of the Balcones Canyonlands and in close proximity to both the Tamaulipan biotic province to the south and the more moist Austroriparian Province to the east. The presence of the Edwards Plateau, the South Texas Brush Country, and the Blackland Prairie within close proximity would have provided a variety of potential consumable resources. Regardless of whether the populations inhabiting the site and its vicinity were pursuing bison herds on the Blackland Prairie, concentrating on the increased abundance of xeric plant resources due to the regional warming and drying trend, or camping in the vicinity of dependable water sources, they were well situated to exploit some resource within close proximity of the site.
The price for the occupation of such a location would have been increased mobility, perhaps in terms of both more frequent and longer distance residential moves as resources became available in different vegetation communities across this vast environmental mosaic.

Although paleoenvironmental data from the proximity of 41CM111 does not exist, the regional data from eastcentral Texas and the northern portion of south Texas seem to support that a drying and warming trend may have been in full swing around $5000 \mathrm{BP}$, roughly the time of occupation of the site. Given the seeming continent-wide scale of this drying trend (Altithermal), it is likely that it also influenced the environs of the site and resource base exploited by its inhabitants. The positioning of the site in a water-rich setting - at the confluence of a major stream and a tributary - may be one indicator of this influence. The reduction of overbank flooding frequencies, and the long-term exposure of the landform and living surface for repeated reoccupation, may have been an additional aspect of site formation conditioned by paleoenvironmental factors.

For the current study, climate and vegetation changes can be grouped into two broad periods, with several smaller intervals present. The first period is the Last Glacial Maxima (18,000-12,000 BP) that predates any known or well-documented evidence of human occupation of Texas. This period was marked by cold conditions becoming warmer and precipitation fluctuating between moist and dry $(13,000-12,000 \mathrm{BP})$. The terminal Pleistocene period (12,000-10,000 BP) represents a brief interval characterized by cool, moist conditions. During the Terminal Pleistocene period, human occupation first occurs and megafauna still inhabit the region, but they become extinct by approximately 10,000 BP. The second major period encompasses the Early and Middle Holocene $(10,000$ $4000 \mathrm{BP}$ ). This was generally characterized by warmer conditions, a trend that continued and accelerated in the Middle Holocene (8000-4000 BP). The Middle Holocene saw a shift to dry conditions and perhaps warm to hot temperatures. A significant shift to more moist conditions, marked by an increase in arboreal pollen, occurred sometime between about 5000 and $6000 \mathrm{BP}$, though the drying and warming trend established at the close of the Late Pleistocene continued until the onset of the Late Holocene. 



\title{
Chapter 3: $\quad$ Archeological Background
}

\author{
Richard B. Mahoney
}

\section{Aboriginal Cultural Setting}

The temporal components identified at 41CM111 fall within the Early and Middle Archaic (e.g., Turner and Hester 1999:62-63), and, as such, this summary of the regional archeological research focuses on these periods. Detailed accounts of the entire chronological and cultural sequence applicable to Central Texas and the eastern edge of the Edwards Plateau can be found in Collins (1995), Johnson (1995), Johnson and Goode (1994), Prewitt (1981), and Turner and Hester (1999). Figure 3-1 depicts various cultural chronologies of Central and South Texas.

Following the Paleoindian period, the Archaic era represents the subsequent 7,600 years of prehistory for this region and is generally subdivided into three separate periods: Early, Middle, and Late. The shift to Archaic hunter-gatherer adaptations commences with the onset of the Middle Holocene geologic epoch, a time of "oscillating" conditions beginning at a moderate climate, trending toward a dry extreme, and returning to moderate conditions throughout the entirety of the era (Collins 1995:383; Johnson 1995). Culturally, the development of the Archaic within this region and, more specifically within the Plains margin proper, may have been attributable to late Paleoindian plainsmen exploiting the woodland-prairie margin and interacting with woodland cultures during times of drought (Johnson 1989).

Early Archaic manifestations within the region include the apparent onset of less specialized subsistence indicated by the diversity of recovered artifact assemblages at numerous sites (e.g., Collins et al. 1990; Johnson 1991). Specifically, woodworking tools such as adzes and wedges begin to appear in the archeological record, as well as multifunctional abraders and scrapers. Hinds Cave (41VV456) in Val Verde County produced numerous bifaces with organic residue indicating vegetal processing (Shafer and Bryant 1977). At the Sleeper site (41BC65) in Blanco County, Johnson (1991) cites the presence of burned rock, manos, and metates as further indicators of a more diversified pattern of subsistence.
This is not to say, however, that hunting decreased dramatically in economic importance. Rather, diversification of the tool kit indicates that other activities, albeit to a lesser yet unknown degree, were now occupying the time of the Archaic peoples. The new activities varied across time and space, but for the most part the majority of assemblages recovered to date indicate that peoples of the early portion of the Archaic era still relied primarily upon meat for the bulk of their diet. Indeed, as evidenced in the 41CM111 lithic assemblage (see Chapter 7), hunting appears to have continued as the most important food-getting activity.

The relatively brief Middle Archaic period at the end of the Middle Holocene may represent a time of transition in adaptation patterns. During the early part of this period, bison are once again present along the plains and prairie regions of Texas after a nearly three millennia hiatus (Dillehay 1974). Xeric conditions, with resultant grassland vegetation as indicated through bog coring to the east (Bousman 1998), would have attracted bison as well as non-local bison hunters to the region. Johnson (1995:86) postulates that it was these interloping hunters who introduced the Calf Creek technology to the Central Texas region; resulting in the promulgation of Bell and Andice projectile points. Regardless of how abundant bison may have been, their appearance in the region is short-lived, and by 5200 BP they once again disappear from the faunal assemblages of sites in the Southern Plains and the adjoining prairie margin (Dillehay 1974).

The decrease in the scale of hunter-gatherer mobility, coupled with a possible increase in seasonal sedentism provided by the exploitation of localized natural resources, is evidenced by the continued occupation and reoccupation of preferred landforms (e.g., Black and McGraw 1985). These adaptations, in response to an increasingly drier environment (c.f. Bousman 1998; Johnson 1995), would form the basis for the transformation in the overall stylistic tradition to that of the succeeding Late Archaic period. The changes may not have been limited to stylistic traditions, as indicated by 


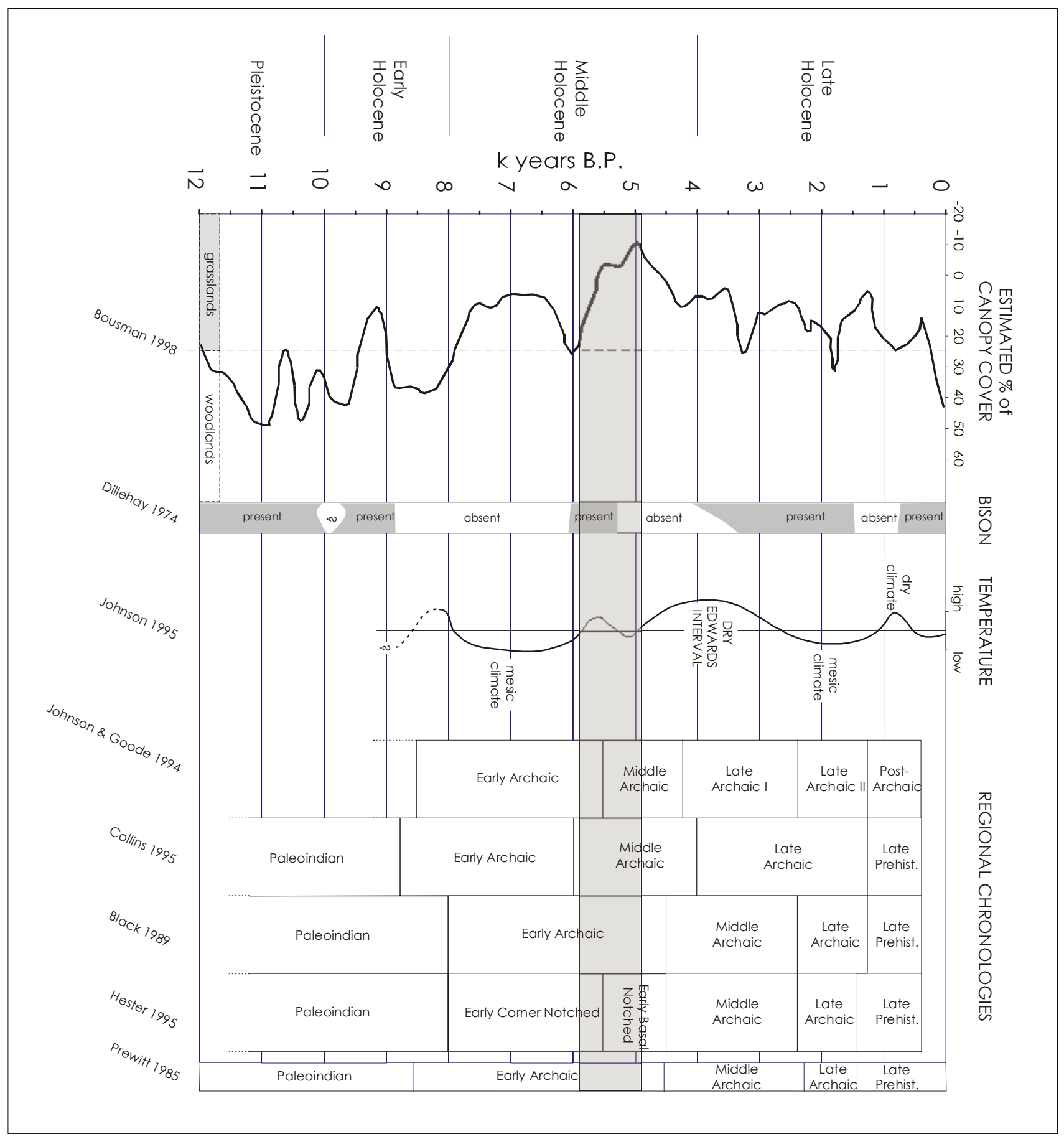

Figure 3-1. Comparative cultural chronologies of Central and South Texas (transparency indicates approximate occupations associated with 41CM111). 
the concentration of sites along the Balcones Escarpment (McKinney 1981). In fact, the analysis of regional settlement patterns and site densities across south Texas indicates a significant under-representation of sites throughout the region bounded by the Nueces River to the north and the Rio Grande to the south (Tomka et al. 1997:Figure 4-6). The majority of the Middle Archaic components tend to be found in the riverine northern portion of South Texas (i.e., north of the Nueces River) and along the Balcones Escarpment (Tomka et al. 1997:Figure 4-6).

The projectile point assemblage recovered during the 1980 excavations at 41CM111 consists primarily of Early Triangular and Nolan dart points. Various chronologies place these diagnostics within different periods and phases (see Collins 1995; Johnson and Goode 1994; Prewitt 1985; Turner and Hester 1999). To facilitate continuity for discussion within this assessment, the various chronologies are summarized in the following, and a qualification for the chosen interpretation is presented.

Johnson and Goode (1994) place both dart point types squarely within the Middle Archaic period, with Early Triangular (ca. $5500 \mathrm{BP}$ ) preceding the Nolan type (ca. 5000 BP). More specifically, according to Johnson (1995:86-89), Early Triangular points were made during the first part of the Middle Archaic, roughly around 5550-5450 BP, while Nolan points may date no earlier than 5050-4950 BP on the eastern Edwards Plateau. Most of the Early Triangular points from the John Ischy site (41WM49) in Williamson County were recovered stratigraphically below Nolan points (Sorrow 1969:Table 4-6). Similarly, at the Landslide site (41BL85) in Bell County, Early Triangular dart points were recovered in the same stratigraphic context as Calf Creek/Bell dart points (Sorrow et al. 1967:Figure 72).

Prewitt (1981) places the two dart point types straddling the transition from the Early to Middle Archaic periods, again with Early Triangular preceding Nolan. The Early Triangular dart points are diagnostics of the Oakalla Phase, which Prewitt (1981:78) dates 5000-4600 BP, or the upper Early Archaic. Nolan dart points are dominant in the succeeding phase, the Clear Fork, which dates to 4600-4000 BP (Prewitt 1981:79 and Figure 4).
Frequently encountered in association with Clear Fork gouges, scrapers, and grinding stones, Nolan dart points have been recovered from components at the Williams site (41TV75; Suhm 1959) and the Crumley site (41TV86; Kelly 1961) in Travis County.

Following Johnson and Goode (1994), Collins (1995) provides a similar temporal relationship between the Early Triangular and Nolan dart points. Again, both types are placed in the Middle Archaic (6900-4500 BP [cal]), with Early Triangular occurring during the middle portion and Nolan occurring during the latter portion of the period (Collins 1995:384). Collins cites the Wounded Eye site (Luke 1980) as a representative component of Early Triangular dart points and Youngsport (Shafer 1963) as representative of Nolan dart points (Collins 1995:Table 2).

At Panther Springs Creek in Bexar County, Black and McGraw (1985:273-279) found that Early Triangular points occurred in the Local Period 5 component of the site, dating to roughly $5330 \pm 170 \mathrm{BP}$. On the other hand, Nolan and Pandale points, among other forms, were most common in the Local Period 6 component dated to 4870 \pm 130 BP. Turner and Hester (1999:Figure 3-7), however, suggest the two dart point types are contemporaneous in the Early Archaic. Moreover, a range of 5950-4450 BP is proposed for Nolan and a range of 5700-5600 BP for Early Triangular (Turner and Hester 1999:108, 164).

\section{Qualification}

While most archeologists working in the state agree with the general sequence of changes in Central Texas projectile points, the chronologies mentioned above differ to some degree, and some variability does exist in the temporal assignments of diagnostic projectile points. For instance, all three of the Central Texas chronologies terminate the Paleoindian period within about 300 years of one another (Figure 3-1). However, major differences exist between archeologists when it comes to the beginnings and durations of the Early, Middle, and Late Archaic periods. By the termination of the Middle Archaic period, for instance, the variation between Johnson and Goode's (1994) and Prewitt's (1981) interpretations is approximately 2,000 years. As such, whether the diagnostics of 41CM111 fall within the 
Early Archaic or the Middle Archaic is not the emphasis here. Rather, the discussion will focus on a number of projectile point types that are typically separated by hundreds of years, yet occur in seemingly contemporaneous context at $41 \mathrm{CM} 111$.

\section{Regional Overview}

Comal and the surrounding counties contain an abundance of prehistoric sites due, in part, to their collective wealth of natural resources. Comal County, alone, has a rich cultural heritage, with 67 historical markers, 13 sites designated as State Archeological Landmarks (SAL), and 11 properties listed on the National Register of Historic Places (NRHP). The majority of these resources are located in the city of New Braunfels, located roughly ten miles downstream of the project area. Nine of the SALs are contained in the Landa Park and Golf Course along the Comal River (e.g., Arnn 1997a, 1997b, 1997c; Bailey and Bousman 1989). The Comal County Courthouse, located in New Braunfels, is the only historic SAL in the county. The three remaining SALs are significant prehistoric sites (41CM51, 41CM91, and 41CM92) located along the Guadalupe River. Of the 11 NRHP properties, ten are located in the city of New Braunfels. The remaining NRHP listing in Comal County is the ca. 1886 historic district of Gruene comprised of 23 similar Late Victorian architectural style structures.

The regional cultural chronology defined by Black and McGraw (1985) at the Panther Springs Creek site (41BX228) appears to also apply to 41CM111. The similarities between the two sites are noteworthy, including feature types, artifact types, and settings (i.e., topography, elevation, and proximity to the confluence of a tributary to a higher order stream). One of the important contributions of the Panther Springs Creek work was the re-evaluation of the Taylor and Baird dart point types (Kelley 1947; Sorrow 1969). Based on their study of these artifact forms from the site, Black and McGraw (1985:276) note that given the high degree of similarity between them, they should be grouped into a single "thinned-base early triangular," or, for this report, simply Early Triangular form. Although Black and McGraw (1985:131) view these tools as knives rather than projectile points, they were able to obtain some very important dates on the levels that contained these Early Triangular forms. The majority of these forms were found in the Local Period 5 component, with an associated radiocarbon date of $5330 \pm 170 \mathrm{BP}$ (TX-3912). The overlying component classified as Local Period 6 contained smaller numbers of Early Triangular forms, while styles such as Nolan, Travis, La Jita, Bulverde, and Pandale were more numerous. The associated radiocarbon date for this component is $4870 \pm 130 \mathrm{BP}$ (TX-3853). The two dates can be used to bracket the period of occurrence of Early Triangular forms. An additional aspect of the Local Period 6 occupation is the "onset" of burned rock midden accumulation at the site (Black and McGraw 1985:278).

\section{Previously Recorded Sites along the Guadalupe River in Comal County}

Over the previous six decades of archeological research within the region, fifty-seven sites have been recorded along the Guadalupe River in Comal County. Stevenson (1951) of the Smithsonian Institution River Basin Surveys conducted the first survey of the Guadalupe River in 1949. This survey resulted in the recording of the first 22 sites along the stream (Texas Historical Commission [THC] 2002). Three of these sites were revisited and excavated by the Texas Archeological Salvage Project (TASP) of the University of Texas at Austin in 1959, immediately prior to construction of Canyon Lake Reservoir (Johnson et al. 1962). The three sites subject to excavation were the Oblate Rockshelter (41CM1), the Footbridge site (41CM2), and the Wunderlich site (41CM3). These excavations also had a great historical significance because they resulted in the establishment of the first regional chronological sequence for Central Texas.

Several cultural resource management projects conducted over subsequent decades are responsible for the balance of known archeological sites associated with the stream. The 1970s and 1980s were the more prolific decades, with seven and nine archeological sites recorded, respectively. The most recently recorded site is 41CM216, encountered by the Texas Water Development Board in 1996 (Davis et al. 1997). To date, no additional sites have since been recorded along the Guadalupe River in Comal County. 


\title{
Chapter 4:
}

\section{Research Perspective}

\author{
Steve A. Tomka and Raymond P. Mauldin
}

This chapter briefly outlines the research perspective that guided the analytical procedures and data collection at site 41CM111. A number of issues are addressed, including the general theoretical basis for interpretation of the archeological record. This is followed by the identification of three research domains investigated with data from 41CM111 in subsequent chapters. These are 1) site integrity and chronology, 2) thermal feature technology, and 3) lithic technology.

\section{Theoretical Perspective}

Our general approach in considering and interpreting the nature of prehistoric occupations and land use is cultural ecology. We view cultural systems as adaptive in that the actors are continually responding to changes in the natural and social realms, including changes that are a product of their own actions. Of particular importance to us are the strategies and tactics used to acquire food, fuel, and raw material resources from the environment. We also recognize that cultural systems are differentiated, that is, different activities are conducted at different times and places across the landscape, depending on specific circumstance. The activities conducted at a location may vary considerably depending on a variety of specific circumstances, and the material remains left by those activities at a location will also vary. Consequently, individuals operating within the same cultural system may generate radically different material cultural remains.

Within this perspective, changes in cultural systems are the result of changing parameters in the natural and social environments. Currently, our understanding of the mechanisms of change in the societal realm are not as well-developed as our understanding of the impact of changes in the natural realm. Especially critical in the latter arena are strategies and tactics related to energy capture, including technology, mobility, and settlement strategies used in resource acquisition. It is in this realm, where cultural systems interact with the paleoenvironment, that extant adaptive strategies are molded and constantly modified. We see changes in those strategies as a result, to a large degree, of interactions at this cultural and natural interface.

We suggest that the archeological record is a current, static phenomenon rather than a fossilized record of past cultural adaptations. That is, the archeological record contains no direct data on the dynamics of past behavior. The record simply consists of artifacts and features spread across the landscape at varying densities. While the artifacts and features were, by definition, created by people at points in the past, a variety of processes have impacted those artifacts and features. These processes include natural and cultural alterations that interact to produce the current record. Researchers then observe that record and interpret that record using a series of conventions. From our perspective, the goal of archeology is to understand those processes that both create the archeological record and shape our interpretations of that record. These processes include culturally organized behaviors, taphonomic processes, methodological decisions, and the conceptual schemes used by archeologists. We are competent at understanding some of these processes, and there are certainly others that we have not yet recognized.

This conception of the archeological record has many implications. One of the critical implications for the current project has to do with the value of archeological deposits. From our perspective, the value of any given archeological deposit is dependent on the research questions asked rather than on any absolute qualities of a site as such. Because archeological deposits possess unique formation histories and characteristics, they provide individual opportunities for improving both our knowledge of the past as well as understanding the implications of our methodological and interpretive decisions. Sites that have mixed deposits, such as 41CM111, can still provide important insights, though the data may be applicable to a more narrow range of research domains or applicable at a scale other than that of the individual site. 


\section{Research Domains}

In the brief research design that accompanied the scope of work for additional field efforts at 41CM111, a series of specific research questions were proposed to document baseline chronological and geomorphic conditions and investigate the nature of the early Middle Archaic thermal feature and the characteristics of lithic technology. Two principal research domains were identified in the scope of work. In addition, a third research domain emerged in discussions with TxDOT archeologists. The three principal research domains addressed in this report are as follow:

1) Evaluate the depositional integrity of site $41 \mathrm{CM} 111$ through a geoarcheological field inspection and, if feasible, collect radiocarbon assays during geoarcheological evaluations to supplement existing samples;

2) Consider the nature and validity of the burned rock sheet midden (originally referred to as a pavement in the Work Authorization) as an identifiable Archaic feature, discuss, when possible, the spatial and chronological aspects, functional applications, duration and seasonality of use, and compare and contrast the feature type to later burned rock midden features in form and function; and

3) Consider the evolution of poorly understood elements of the early Middle Archaic lithic assemblage(s) by addressing the design, function, and reuse of the Early Triangular biface, the association between lithic tool kit(s) and other campsite features, and the spatial and chronological distributions and variations of the early Middle Archaic regional tool kits.

The first of these considers issues related to the integrity and chronology of the site. Using a variety of data sets, including stratigraphy, refit studies, magnetic sediment susceptibility, radiocarbon dating and the distribution of temporally diagnostic projectile points, we argue that although the site's deepest explored deposits fall within a reasonably tight temporal range, the mix of diagnostic projectile points indicates repeated reoccupation of a stable or slowly aggrading land surface resulting in some admixture of components. We also argue that the burned rock sheet midden and the thermal features identified by the 1980 and 2002 excavations are the products of the same phenomenon of the repeated reoccupation of the surface over an extended period of time resulting in the continuous disturbance of previous hearth features and the construction and abandonment of new ones prior to site abandonment. We argue that the burned rock sheet midden noted on-site is a palimpsest of cultural materials accumulated during repeated reoccupation of a site situated on a slowly aggrading or even stable landform.

A number of specific data types and special analyses were carried out within each of these three research areas. Our investigation and documentation of site integrity and chronology, presented in Chapter 8, relies on the distribution of temporally diagnostic projectile point types within the site, as well as the results of special analyses including descriptions of site stratigraphy and geomorphology, investigations of potential patterns in magnetic sediment susceptibility, and selected radiocarbon dating of both charcoal and humate samples.

The investigation of thermal feature technology, presented in Chapter 9, is concerned with developing an understanding of the formation processes responsible for the burned rock sheet midden present at the site. Beginning with the site specific data, the feature typology of other thermal features is also reviewed to provide a more complete context for interpretation.

In Chapter 10, the discussion of the lithic technology considers the early Middle Archaic lithic collection recovered from the site, and compares it with other collections of similar age from other parts of the state. 


\title{
Chapter 5: $\quad$ Field and Laboratory Methods
}

\author{
Richard B. Mahoney
}

\section{Introduction}

This chapter discusses field and laboratory methods employed during all phases of investigations conducted at 41CM111. Therefore, this chapter includes summaries of the 1980 TxDOT (SDHPT) work, the 2001 CAR assessment, and the 2002 CAR field and laboratory efforts. The 1980 TxDOT investigations will be detailed first since they strongly influenced the subsequent work conducted by CAR.

\section{The 1980 Investigations}

\section{Field Efforts}

Sometime prior to 12 March 1980, an auger probe excavated 50-100 ft east of STA 628 along FM 306 recovered a single Early Triangular dart point, numerous lithic debitage, and two fragments of freshwater mussel shell (daily journal, 41CM111 collections, CAR). The presence of these artifacts, in addition to the lithic debitage and burned rock fragments exposed in the extant road cut, resulted in the designation of the locality as site 41CM111. Subsequently, the presence of buried cultural materials, including a temporal diagnostic artifact, precipitated further cultural resource investigations prior to proposed roadway improvements.

On 17 March 1980, TxDOT personnel began excavations at 41CM111. The first $2 \times 2-\mathrm{m}$ unit (U1) was situated over the auger-boring at grid coordinate N106/E196. Upon identification of a probable buried living surface at a depth of approximately $70 \mathrm{cmbs}$, additional adjoining units were excavated to further expose the former living surface. Figure 5-1 shows the southern extension of this buried surface in Unit 8, south of FM 306. In total, a block of six 2 x 2-m units (U1-U6) was thus excavated north of FM 306 near the toe of the adjacent upland ridge (Figure 5-2). Four additional 2 x 2-m units (U7-U10) were excavated south of the road and produced cultural materials consistent with those found on the north side of the road. Construction of the road is estimated to have obliterated approximately one-third of the estimated $900-\mathrm{m}^{2}$ primary midden deposit. Three site-delimiting units (U11-U13) were excavated northwest of the concentration, yielding relatively little cultural material. Cordova Creek provides the southeast boundary of the site as expressed within the TxDOT right-of-way (ROW). No work was conducted outside of the ROW to determine the remaining site boundaries.

Initially, the deposits were excavated in arbitrary $10-\mathrm{cm}$ levels. The uppermost six levels revealed no indication of cultural or natural stratigraphy. However, in Level 7 $(60-70 \mathrm{cmbs})$ of the first test unit, the crew encountered a rich zone of cultural material that extended through Level 9 ( $80-90 \mathrm{cmbs})$. The remainder of the $24-\mathrm{m}^{2}$ block was subsequently excavated to reveal the upper aspect of this zone in Level 7 (see Figure 1-3), or $70 \mathrm{~cm}$ below the datum for Unit N106/E196 (U1). This cultural zone consisted of a burned rock sheet midden spread across the former surface. Within this midden, the crew identified and documented six features. The midden exhibited a relatively flat surface layer, with only $2.7 \mathrm{~cm}$ of relief across the block.

Once the former surface was exposed, the excavation levels were subdivided into two 5 -cm sublevels for better vertical control. This subdivision continued throughout the midden and occasionally reverted to $10-\mathrm{cm}$ levels below the midden. The average terminal depth of the units was approximately $100 \mathrm{cmbs}$, although the range extended from $50 \mathrm{cmbs}$ (U13) to $140 \mathrm{cmbs}$ (U10 and U14). A total of $50.34 \mathrm{~m}^{3}$ was excavated through the 146 person days expended during the investigations.

\section{Laboratory Methods}

A number of special samples were collected during excavation. They included five charcoal samples recovered in association with the midden encountered in the main block excavation. Three large ( $\sim 5$ liter) soil samples also were extracted from Feature 3, the hearth feature identified in the sheet midden. Abundant freshwater mussel shell also was collected from the midden. 


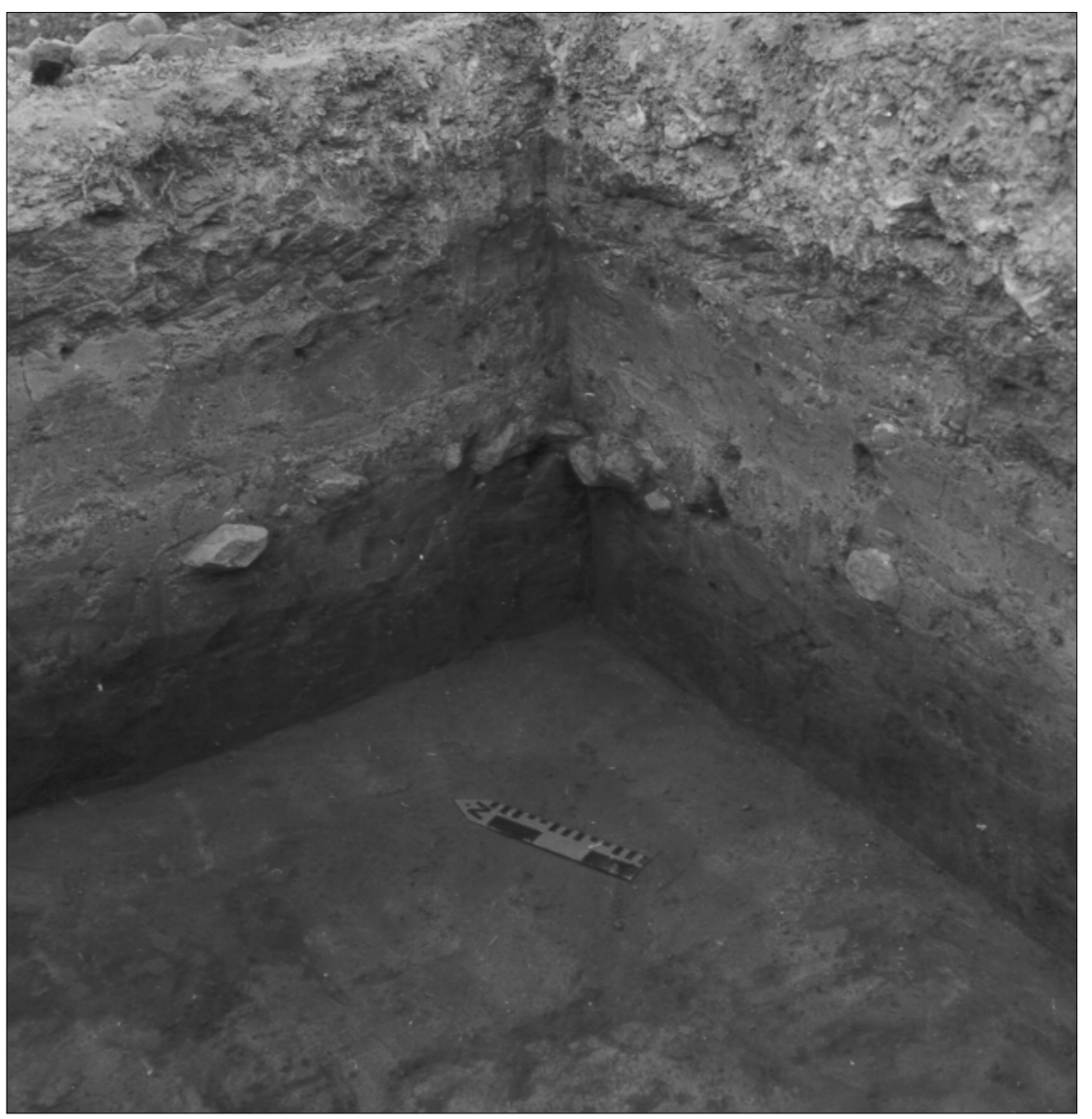

Figure 5-1. 1980 Excavation Unit 8 (N80/E200) at bottom of Level 10. Note buried living surface in wall profile.

Certain classes of artifacts were not collected or recorded. Specifically, abundant burned rock is evident in the numerous photographs and plan view maps, however, only 53 lots contained burned rock. The few burned rock samples that were retained for curation do not appear to be the products of a systematic collection strategy. Additionally, terrestrial snail shells were not collected and/or recorded systematically. According to field notes, the collection of snail shell was terminated on 26 March 1980. Prior to that time, all snail shell was collected and recorded. Fortunately, the excavation of Unit 1 was near completion prior to this executive decision, and the unit produced a near-complete vertical column replete with Rabdotus from ground surface to below the midden.

All material collected in the field was placed in paper or plastic bags with provenience data recorded on the exterior of the bags. Artifact counts by class were inconsistently recorded on individual unit level forms. A lot log was maintained in the field and provides a generalized list of artifact categories, artifact counts, and occasional artifact sketches.

Following excavation, the collection of artifacts and supporting documentation was temporarily housed at TxDOT facilities until their transfer to the CAR facility. While within TxDOT custody, efforts had been made to properly conserve the materials for curation. Additionally, limited work had gone into the cataloging of the collection, the creation of a formal database, and basic artifact analysis.

While at TxDOT, basic laboratory procedures were followed to catalog the artifacts. Artifacts contained in paper bags were placed in polypropylene bags and relabeled. All diagnostic artifacts, bifaces, and modified 


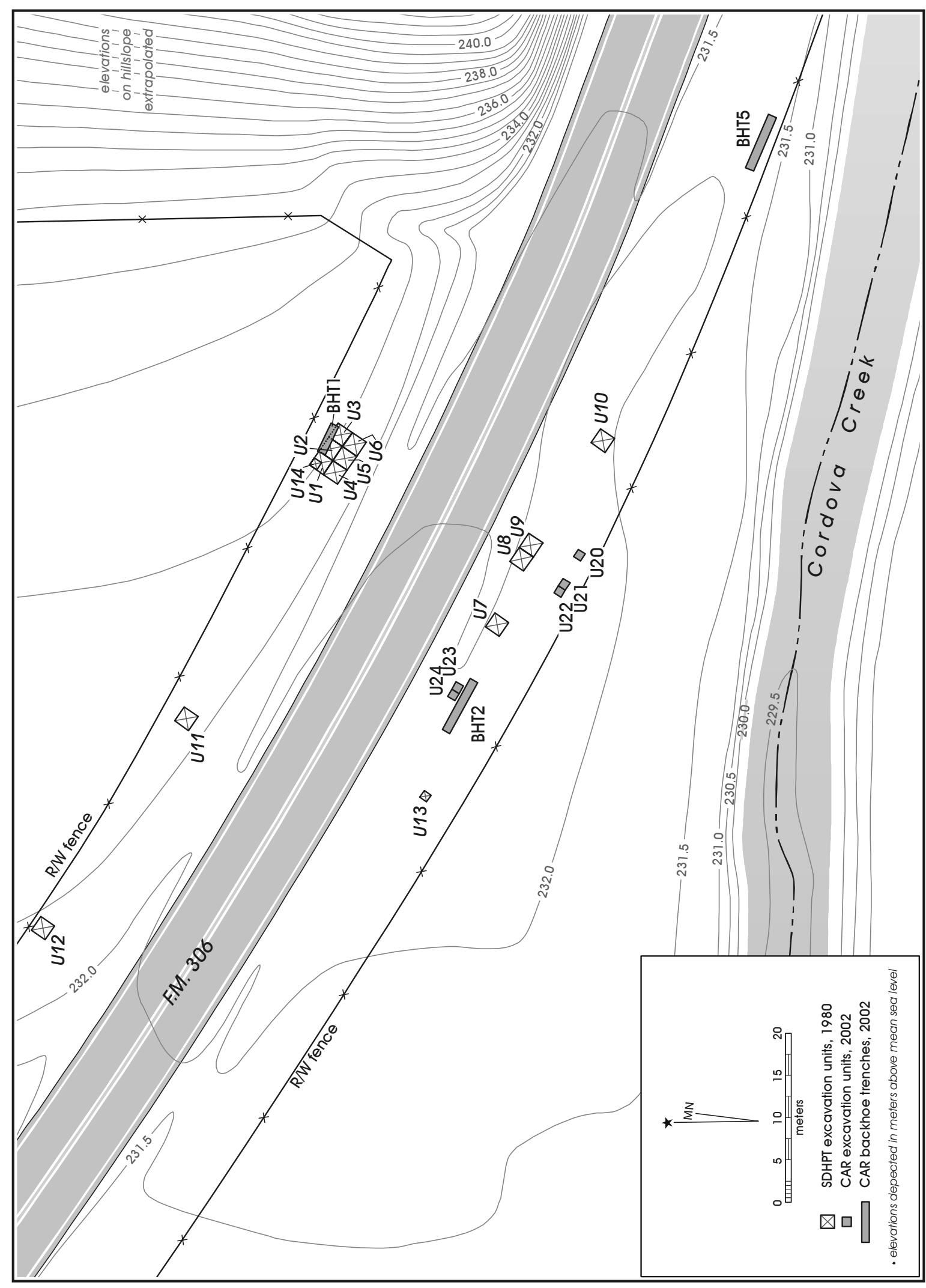

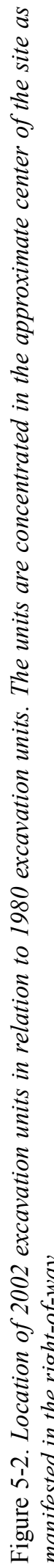


flakes, and representative lithic debitage were labeled with indelible ink and coated with an unknown clear film. The acidic labels contain at least the site trinomial and the relevant lot number. However, no specific catalog numbers were assigned during the laboratory process.

It is inferred that an additional lot index was created at this time. The second index contains a much more detailed description of the contents of each lot. The lithic debitage was categorized by flake attributes: primary, secondary, and interior. The terrestrial snail shell and, less systematically, the freshwater mussel shell collections were sorted and identified by genus and species. Diagnostic projectile points were occasionally sketched and identified by type. The timing of these later laboratory processing efforts is not known.

Nevertheless, it is apparent that Alan Wormser looked at the collection sometime in 1986, typed some of the projectile points and produced a site grid map. In addition, Wormser poured over some of the more vague journal entries and unit level forms, providing additional notations and clarifications (e.g., daily journal, 25 April 1980, 41CM111 collections, CAR).

\section{The 2001 Assessment}

In 2001, CAR produced a brief assessment report documenting the completeness and quality of the site records and evaluating the research potential of the artifact and ecofact collections derived from the 1980 excavations (Mahoney 2001). The document provided the following:

1) A summary description of the excavations and laboratory procedures followed and documentation produced prior to the assessment;

2) A summary description of the materials available for analysis;

3) An assessment of the completeness of the records and artifact collection; and

4) A description and assessment of the utility of the documentation for assessing the integrity of the materials recovered from 41CM111.
While weaknesses in the written documentation were apparent, overall, both the artifact collection and the documentary evidence were fairly complete. However, because the geomorphic processes that led to the preservation of the site were not well understood, the vertical distribution of temporal diagnostic projectile points raised some concerns about site formation processes, and because there was an overall scarcity of datable materials from well-documented contexts at the site, TxDOT requested additional field investigations.

\section{The 2002 Investigations}

\section{Field Efforts}

Prior to initiation of the formal field investigations, a reconnaissance was conducted on 2 March 2002 to assess the condition of the project area. This reconnaissance was deemed necessary to evaluate what modifications may have impacted the site since the 1980 investigations. Most obvious was the re-grading of the ROW, especially on the north side of FM 306.

A conversation with Mr. Robert Scheel (of the TxDOT New Braunfels Area Office) following the site visit confirmed this observation. According to Mr. Scheel, at least one foot - possibly two feet - of the original ground surface was removed from the northern ROW to build the additional six-foot-wide shoulders along FM 306 in 1980. Indeed, moderate amounts of cultural material were visible along the northern ROW, with approximately 35 percent ground surface visibility. Mr. Scheel further recalled that little, if any, of the southern ROW was removed for construction purposes.

Since that time, other safety and utility-related disturbances have impacted 41CM111 within the current ROW. Mr. Rick Hanks, TxDOT Engineering Technician, New Braunfels Area Office, indicated that additional grading of the ROW probably occurred sometime in the early1990 s for updated safety considerations (personal communication 2002). In addition, several roadway signs have been installed within the site bounds. An inspection of the immediate ground surface surrounding each sign reveals moderate amounts of burned rock, freshwater mussel shell, and debitage. A fiber optics cable had recently been installed along the extreme southern 
portion of the southern ROW. While it was apparent that the installation was quite recent, as evidenced by the exposed fiber optics cable in the streambed of Cordova Creek, no cultural material was noted along the backfilled portions of the utility trench.

As a permanent site datum was not established during the 1980 investigations, landmarks sought for relocation of the various excavation units were those that could have survived for over 20 years. A review of the 1980 site photographs indicated a distinctive north ROW fence constructed entirely of unhewn juniper. A conversation with the adjoining landowner, however, revealed that the fence had since been replaced with identical materials utilizing new fence post locations. Unfortunately, this replacement had occurred less than six months prior to the 2002 CAR field investigations.

As such, the only remaining landmark that appeared on previous site maps was the southwest corner of the FM 306 bridge spanning Cordova Creek (see Mahoney 2001:Figure 2). While the scale on this map was erroneous, extrapolations from a 1986 map produced by Alan Wormser (41CM111 collections, CAR) allowed for a confident, corrected measurement. A bearing from the southwest corner of the bridge was taken to relocate the northeast corner of U9. This locus, the northeast corner of U9, was used as the site datum for the 2002 investigations.

The primary purpose of the 2002 field investigations was to augment data recovered during the 1980 excavations. The excavations consisted of three $1 \times 1-\mathrm{m}$ units (U20, U21, and U22) and a single $1 \times 2-\mathrm{m}$ unit (U23; see Figure 5-2). These units were excavated in arbitrary $10-\mathrm{cm}$ levels and excavations terminated $10 \mathrm{~cm}$ below the deepest cultural material. All manually excavated materials were dry-screened through $1 / 4$-inch hardware cloth. A total of $3.5 \mathrm{~m}^{3}$ was excavated.

Due to the undetermined level of disturbance incurred in the northern portion of the ROW and the higher volumetric density of diagnostics recovered on the south side of FM 306, the 2002 investigations focused south of the road. Ideally, the current, comparative units should have been placed immediately north of these southern units so as to be closer to the center of the site. The previous disturbance associated with the addition of the six-foot shoulders precluded this preferred placement, and thus prescribed the location south of the previously excavated units.

The 1980 contiguous block consisting of U8 and U9 was targeted for current excavations due, primarily, to the high density of diagnostic stone tools recovered from U8 (see Mahoney 2001:Appendix 2). While U7 admittedly possessed a greater density of diagnostics, it was not possible to precisely relocate the unit. Accordingly, three $1-\mathrm{m}^{2}$ units (U20, U21, and U22) were placed south of the $19802 \times 4$-m block (see Figure 5-2).

Five backhoe trenches (BHTs) were excavated on and in the vicinity of the site to allow the geoarcheological investigation of site preservation and formation processes. Backhoe Trenches 1 and 2 were excavated within the site boundaries, while BHTs 3-5 were dug off site to assess the broader geomorphic context of the site. The trenches were approximately one meter $(3 \mathrm{ft})$ wide and varied from five to ten meters $(15-30 \mathrm{ft})$ long. Backhoe trenches exceeding 1.5 meters in depth were widened at the top to eliminate the potential for wall collapse. Specifically, in order to conform to Occupational Safety and Health Administration (OSHA) standards for protection of employees in excavations (29CFR1926.652), safety benches were mechanically excavated around the perimeter of backhoe trenches. Each safety bench was excavated to adequate depths to maintain proper slope angles required under these provisions. The backhoe trench excavations were closely monitored and mechanical excavation was terminated at the first recognizable sign of cultural features (see Chapter 7, Results of Investigations).

BHT-1 was positioned to expose the northern wall of the 24- $\mathrm{m}^{2} 1980$ excavation block. By means of correct extrapolation from the 1986 Wormser map, this interface was encountered revealing sparse burned rock, charcoal, and an Early Triangular dart point in the north wall of the trench. The excavation of BHT-2 led to the discovery of a buried hearth feature in the north wall profile.

Although due to the rather limited research issues being pursued, the 2002 CAR excavations were originally limited to $3 \mathrm{~m}^{3}$. The encounter of a hearth feature in BHT-2 expanded slightly the intended level of effort expended at 41CM111. The relative dearth of cultural 
material recovered in the initial three excavation units (U20-U22) and the total lack of cultural features justified the excavation of the additional $0.5 \mathrm{~m}^{3}$ (U23) to adequately record and excavate the feature encountered in BHT-2.

\section{Laboratory Methods}

All artifacts encountered in test units and all diagnostic artifacts encountered in backhoe trenches were collected for curation. Charred or unburned organic materials critical to ${ }^{14} \mathrm{C}$ site and component dating were recovered when found in primary contexts. Soil column samples, consisting of 200-300 gram matrix samples, also were collected from undisturbed contexts for future oxidizable carbon ratio analysis. No human remains were encountered during any excavations.

Upon completion of each day of fieldwork, all recovered artifacts and special samples along with associated paperwork were submitted to the CAR laboratory for processing and temporary curation. Processing consisted of artifact washing, a general category sort, cataloging, and entry into a Microsoft Access $2000^{\circ}$ database. Subsequent to this initial laboratory processing, the various artifact categories were submitted to specialists for analyses. Following the formal analyses, the results were then incorporated into the final curation database.

Concomitant with processing the 2002 excavated materials for curation, several procedures were necessary to make ready the 1980 artifacts and ecofacts for final curation. First and foremost, the collection inventory was revised to accommodate minor discrepancies in artifact identification. In particular, items misidentified during the 1980 laboratory efforts such as natural rock, caliche root casts, and other non-cultural materials were discarded. In addition, some items such as heat spalls were misclassified as lithic debitage and vice-versa and needed proper identification. In this manner, the counts for various artifact classes changed and required the updating of the final inventory.

Finally, because some of the previous TxDOT laboratory processing did not meet current standards, the majority of the specimen labeling had to be redone due to inappropriate, inaccurate, or illegible labels. This procedure required removal of the older labels with acetone and the subsequent relabeling with the correct identifiers. Correspondingly, artifact tags and bags needed to be replaced with archivally stable materials.

Documentation of the recovered materials similarly required stabilization for curation. All documents produced on non-acid-free paper necessitated photocopying onto acid-free paper. The original documents were then placed in archival-quality plastic sheet protectors. Photographs produced on non-archival paper were also placed in archival-quality plastic sheet protectors.

Final curatorial processing was conducted in accordance with 36CFR79 (Curation of Federally Owned and Administered Archeological Collections) and other proprietary standards adhered to by CAR, the permanent curatorial facility for the project. 


\title{
Chapter 6:
}

\section{Geoarcheology}

\author{
Lee C. Nordt
}

The purpose of this chapter is to reconstruct the late Quaternary alluvial history of the Guadalupe River and Cordova Creek in the vicinity of site 41CM111. Time diagnostic artifacts from both the 1980 and 2002 excavations indicate that the site falls within the early portion of the Archaic era.

\section{Setting}

The Guadalupe River valley drains primarily the Lower Cretaceous Glen Rose Limestone before cutting through the faulted Edwards Limestone near the study area (Barnes 1982). The modern meanders are deeply entrenched into limestone, and in the project area narrow strips of terrace alluvium occur on both sides of the channel. Cordova Creek is a low order tributary of the Guadalupe River and drains principally the Edwards Limestone. Site 41CM111 is located within a valley bordered by uplands to the east, Cordova Creek to the south, Heiser Creek to the north, and the Guadalupe River to the west (Figure 6-1). The soil in this area is mapped as Boerne fine sandy loam, a weakly developed ustochrept (Batte 1984). However, surface horizon textures are clay loams rather than fine sandy loams. The Boerne delineation parallels the Guadalupe River and crosscuts Krum soils coming down the Cordova Creek valley. The surrounding upland soils are typically mapped as Brackett, a shallow limestone soil.

\section{Methods}

Five backhoe trenches were opened in the study area (see Figure 6-1). BHT-1 was excavated adjacent the 1980 main excavation block north of FM 306, and BHT-2 in the vicinity of 1980 units 7, 8, and 9 south of FM 306. BHT-3 and BHT-4 were opened downslope towards the Guadalupe River and BHT-5 towards Cordova Creek. Soil-stratigraphic descriptions were written following standards and procedures of the Soil Survey Division Staff (1993). Four radiocarbon ages are reported for the geoarcheological chronology (Table 6-1), after correcting for variations in $\delta^{13} \mathrm{C}$ content by Beta Analytic, Inc.

\section{Alluvial Stratigraphy}

Cursory observations of a road cut from FM 306 on the west side of the Guadalupe River revealed channel gravels and sands grading up into a reddish brown surface soil containing 15 to 20 percent carbonate nodules. This is consistent with the mapping of the Sunev soils, which are calciustolls (Batte 1984). The degree of soil carbonate development suggests that this is a late Pleistocene terrace (Blum and Valastro 1989, 1994).

The Holocene alluvial stratigraphy in the project area is subdivided into an early Holocene unit (EH) and late Holocene unit (LH; Figure 6-2). The EH unit was exposed in BHT-1, BHT-2, and BHT-3 (see Figures 6-1 and 6-2). Complete exposure of the surface soil in BHT-1 revealed an A-Bw-Bk profile with textures of clay loam to silty clay loam, colors of very dark grayish brown over yellowish brown, and filaments of carbonate in the Bk horizon (Appendix A). This is consistent with classification of the Boerne series, except for a finer surface horizon texture. BHT-2 is nearly identical to BHT-1, except the surface horizon was destroyed during road construction, and because of greater depth of excavation, light yellowish brown loams were encountered at $186 \mathrm{~cm}$. BHT-3 exposed the EH unit on a slope grading towards the Guadalupe River. Based on partial preservation of the surface horizon (beneath road fill), the surface probably represents a sloping depositional terrace surface. Subsurface soil morphology is similar to BHT-1 and BHT-2. The chronology of the upper $\mathrm{EH}$ unit was established by three radiocarbon ages dating to $4990 \pm 40 \mathrm{BP}$ (from N104/E196), $4820 \pm 60 \mathrm{BP}$ (from N106/E198), and $4340 \pm 70$ BP (from BHT-2; see Table 6-1).

The LH unit near the Guadalupe River was exposed in BHT-4 as an inset alluvial fill (see Figures 6-1 and 6-2). Here, an over-thickened dark gray silty clay loam surface horizon grades down into a dark grayish brown loam $\mathrm{C}$ horizon containing abundant, coarse channel gravels (Appendix A). In BHT-5, the LH unit is inset to the EH unit by Cordova Creek (see Figures 6-1 and 6-2). 


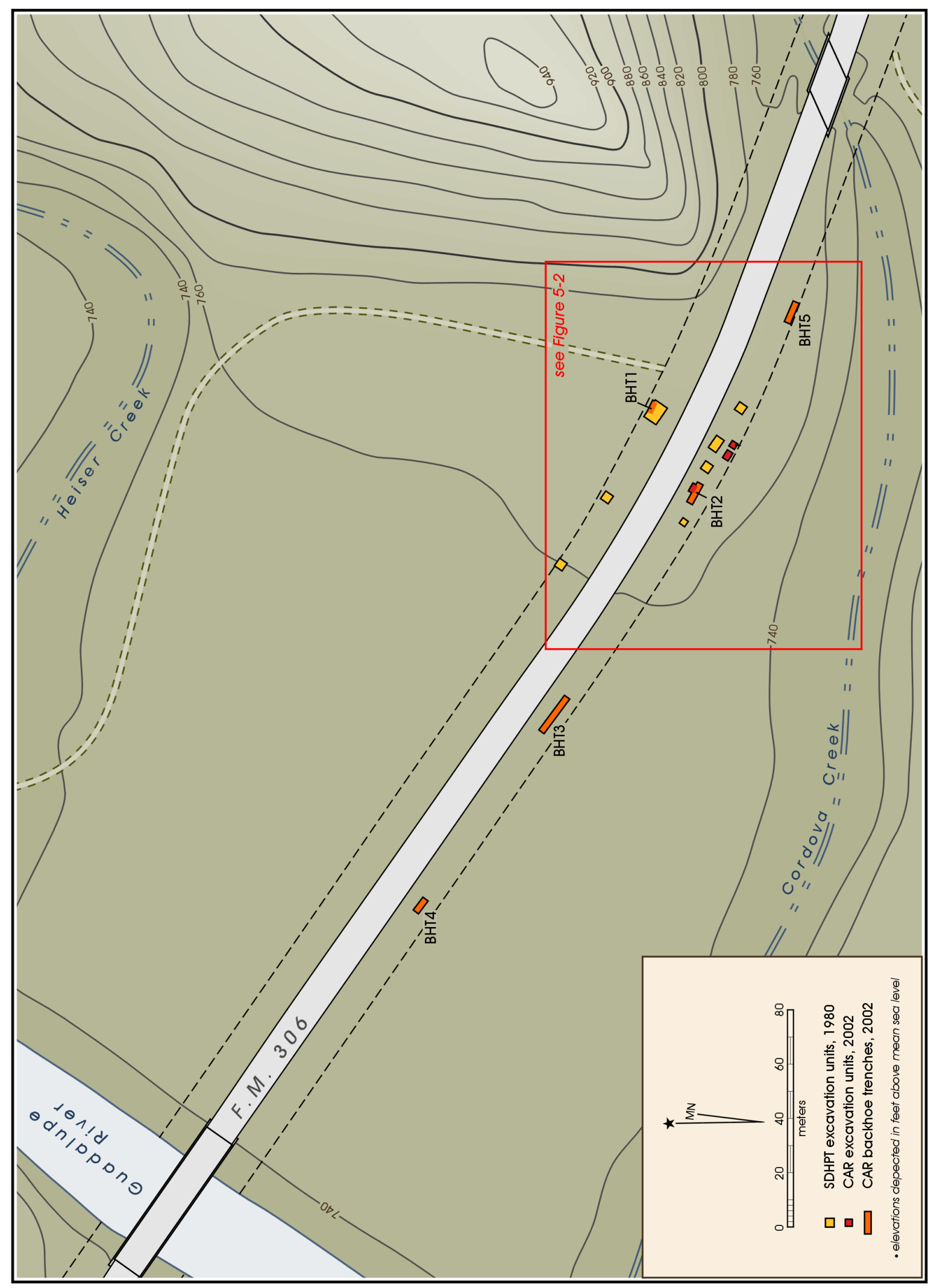

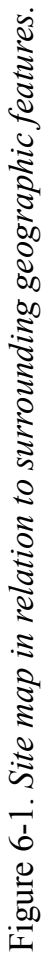


Table 6-1. Beta Analytic, Inc. results of radiocarbon dating for samples recovered from 41CM111

\begin{tabular}{|c|c|c|c|c|c|c|c|c|c|c|c|}
\hline $\begin{array}{l}3 \\
\stackrel{0}{0} \\
\stackrel{0}{0} \\
\end{array}$ & 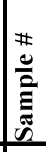 & 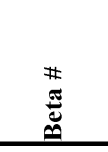 & & $\stackrel{\#}{\text { \# }}$ & 音 & 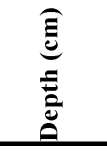 & 包 & Associated Diagnostics & $\begin{array}{c}\text { Conventional } \\
\text { Radiocarbon } \\
\text { Age } \\
\end{array}$ & $\begin{array}{c}\text { Calibrated } \\
\text { BP Range } \\
\text { at } 1 \text { Sigma } \\
\end{array}$ & $\begin{array}{r}\text { Calibrated } \\
\text { BP Range } \\
\text { at } 2 \text { Sigma } \\
\end{array}$ \\
\hline TxDOT & 1 & 166715 & $02 \mathrm{H} 1$ & $02 \mathrm{H} 1-3$ & 2 & $70-75$ & 071.30 & Early Triangular (1) & $4820+/-60$ & $5600-5480$ & $5650-5340$ \\
\hline TxDOT & 2 & 166716 & 04I 2 & $04 \mathrm{I} 2-2$ & 4 & $85-90$ & 048.18 & Early Triangular (2); Nolan (1) & $4990+/-40$ & $5740-5660$ & $5880-5620$ \\
\hline CAR & 6 & 166720 & BHT2 & BHT2-1 & $\mathrm{BHT} 2$ & a,56 & 147.20 & Burned Rock Feature & $4340+/-70$ & $4970-4840$ & $5220-4820$ \\
\hline CAR & 7 & 166721 & BHT5 & BHT5 & BHT5 & $165-170$ & 293.40 & (humate) & $2930+/-40$ & $3204-2995$ & $3237-2950$ \\
\hline
\end{tabular}

Sediment lithology consists of stratified brown and yellowish brown sandy clay loams and clay loams, interbedded with weakly developed paleosols and pebble lines. A radiocarbon age of $2930 \pm 40$ was obtained from the LH unit in BHT-5 adjacent to Cordova Creek (see Figure 6-2).

Quaternary landscape evolution in the project area began with deposition of late Pleistocene alluvium west of the Guadalupe River (see Figure 6-2). After a period of channel erosion, deposition of the EH unit began and proceeded to no later than $4300 \mathrm{BP}$. Only the flood basin facies of the EH alluvium was exposed, which consists of non-stratified, fine-grained textures indicative of low magnitude floods. Another period of channel erosion ensued shortly after $4300 \mathrm{BP}$ as both the Guadalupe River and Cordova Creek downcut into bedrock, transforming the EH surface into a terrace or flood terrace. Afterward, deposition of the $\mathrm{LH}$ alluvium began with flood deposits partially burying the EH unit. Flood magnitudes appear to have increased in the late Holocene because the LH channel deposits contain an abundance of coarse cobbles with little over-bank deposition.

The chronology established in the study area correlates well with the alluvial histories of other rivers and creeks in the region. Blum and Valastro $(1989,1994)$ dated late Pleistocene terraces along the bedrock confined Pedernales River and along the larger Colorado River to between 14,000 and 20,000 BP. These terraces have similar Stage 2 soil carbonate morphology to the Sunev soils identified on the west side of the Guadalupe River. Followed by a regional episode of channel downcutting some time between 14,000 and 11,000 BP, Blum and Valastro dated an early Holocene unit to between approximately 11,000 and $5000 \mathrm{BP}$, which was followed by yet another episode of channel erosion between 5000 and 4000 BP. Likewise, Nordt $(1996,2001)$ identified an early Holocene unit along Culebra Creek and Leon Creek dating to approximately the same time interval. The EH unit in the current project area appears to have been deposited coevally with other regional streams.

Blum and Valastro $(1989,1994)$ and Nordt $(1996,2001)$ dated a late Holocene unit to between approximately 4000 and at least $1000 \mathrm{BP}$, which appears to encompass the LH unit in the project area. As with other regional studies, the lithology of the LH unit indicates that higher magnitude flooding began in the late Holocene.

\section{Geoarcheology}

\section{Prehistoric Site Formation and Preservation Potentials}

The Early Archaic features constituting site 41CM111 were buried within the upper meter of the EH alluvium (see Figure 6-2). The features are contained within the subsurface $B$ horizon indicating that burial occurred from rapid deposition associated with high frequency, low magnitude flooding. This setting is ideal for the burial of features in primary contexts. Deposition of the EH unit slowed shortly after $4300 \mathrm{BP}$, as the stream network downcut before depositing the $\mathrm{LH}$ alluvium. There is no geological reason for the absence of features on the surface of the EH unit. If present, they would span the Middle Archaic to Historic periods. Based on the inferred chronology from regional correlation, late Paleoindian features might be encountered with depth in the EH alluvium. 


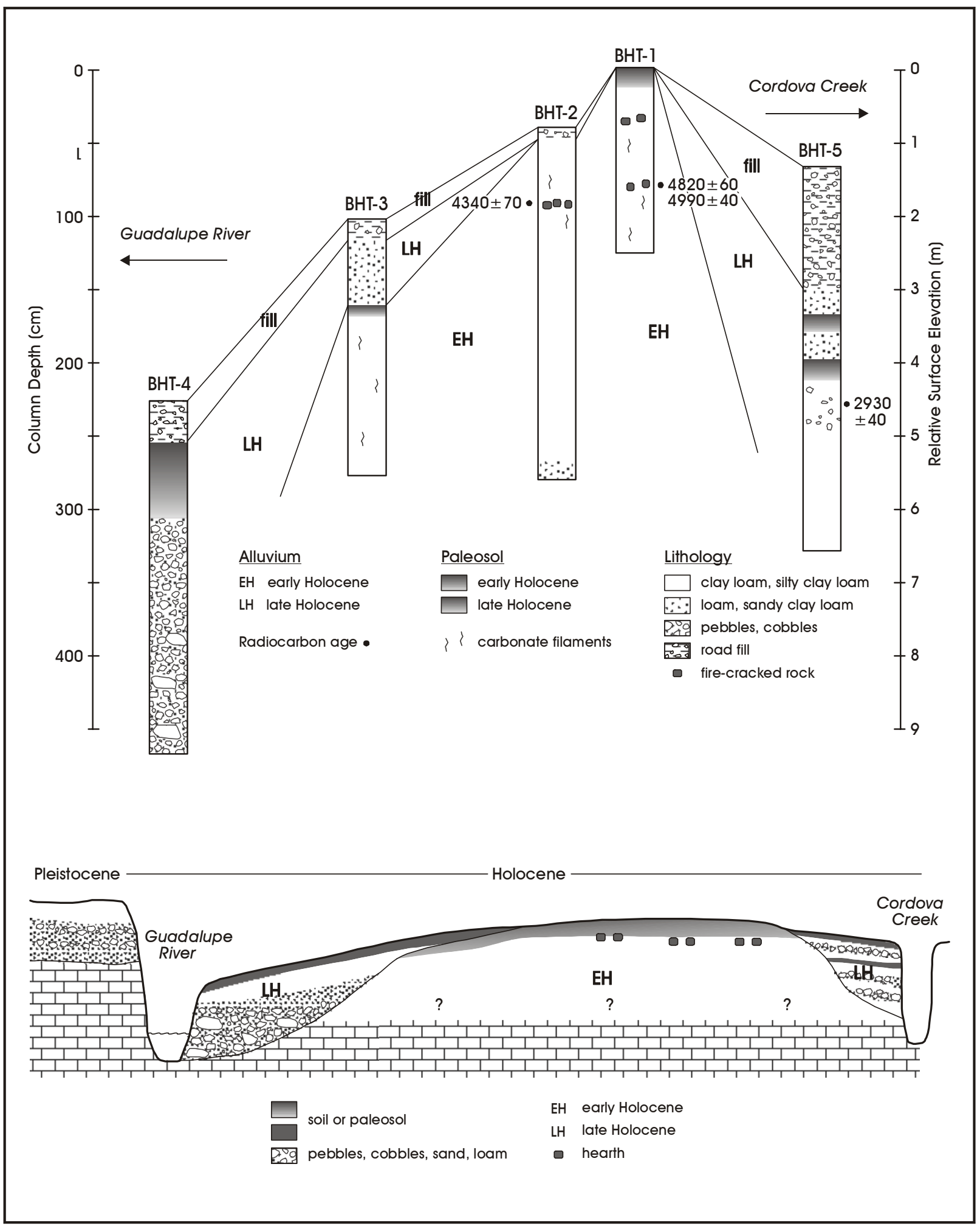

Figure 6-2. Detailed soil-stratigraphic profiles from backhoe localities (top) and schematic alluvial stratigraphic cross-section of the project area (bottom). 
Chronologically, the LH unit could contain buried Middle Archaic to Late Prehistoric features (see Figure 6-2). However, within the upper meter, features dating to the Late Archaic to Late Prehistoric are more likely to be encountered. Preservation potentials in primary context would be much lower below a one-meter depth in the LH alluvium because of the presence of cobbly channel deposits. Contextual integrity might be somewhat higher for features buried deeply in LH alluvium of Cordova Creek. Further, the surface of the EH unit could contain single-component Early to Middle Archaic features where buried by a veneer of $\mathrm{LH}$ alluvium shortly after $4300 \mathrm{BP}$. The lateral limits of site 41CM111 are geologically determined by the extent of erosion created by LH alluvial channel migration of the Guadalupe River and Cordova Creek.

\section{Landscape Evolution and Settlement Pattern}

Holocene landscape evolution of the Guadalupe River and Cordova Creek may have influenced settlement patterns in the project area. The Holocene alluvial sequence is oriented parallel with the Guadalupe River, which crosscuts alluvium from Cordova Creek (Figure 6-3). This, coupled with radiocarbon dating, indicates that the EH channel and Cordova Creek confluenced much nearer to site $41 \mathrm{CM} 111$ during its formation, than today. The confluence between the two streams probably served as a favorable area for Early Archaic resource procurement. The Guadalupe River then began to migrate westward and downcut shortly after $4300 \mathrm{BP}$ in the vicinity of the boundary between the $\mathrm{EH}$ and $\mathrm{LH}$ alluvium (see Figure 6-3). Migration continued in the late Holocene to the location of the modern channel. Westward migration of the Guadalupe channel during the middle and late Holocene, channel downcutting shortly after $4300 \mathrm{BP}$, and increased flood magnitudes in the late Holocene created several important changes in the landscape that probably contributed to site abandonment during the late Early Archaic. First, by 4300 $\mathrm{BP}$ and continuing thereafter, the confluence of the river and creek channel moved much farther away from the site, thus reducing accessibility to an important dual resource base. Second, as flood magnitudes became greater and more unpredictable, the risk of occupying such an area would have increased as well. 


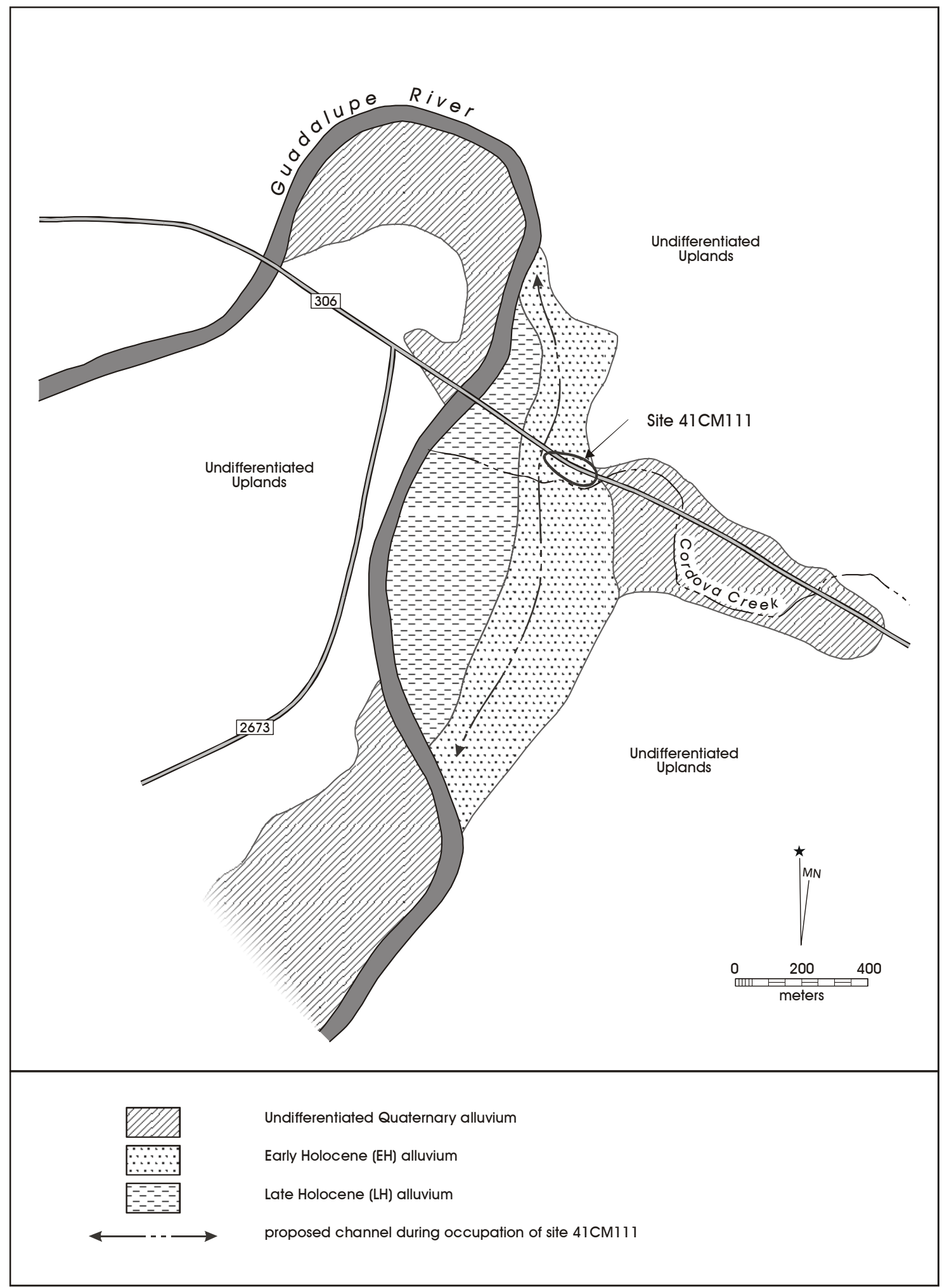

Figure 6-3. Geomorphic map projecting locations of EH and LH meander belts and alluvium in relation to site 41CM111. 


\title{
Chapter 7:
}

\section{Results of Investigations}

\author{
Richard B. Mahoney, Harry J. Shafer, and Steve A. Tomka
}

\section{Introduction}

In this chapter, we discuss and summarize the materials recovered from both seasons of fieldwork at 41CM111. As mentioned in Chapter 4, while numerous data sets comprise the overall assemblage of the materials recovered from 41CM111, only a select few were targeted for detailed analysis. The original TxDOT Work Authorization and scope of work established specific research goals that detailed the level of effort to be expended during analyses. The classes of materials excluded from in-depth analysis consist of mussel shell, terrestrial snail shell, macrobotanical remains, faunal remains, and microscopic pollen and phytoliths. The quantities of materials recovered in these classes of artifacts and ecofacts will be addressed, however, at the end of this chapter.
The 1980 excavations resulted in the recovery of large quantities of mussel shells $(7,208 \mathrm{~g})$, moderate quantities of snail shells $(2,547 \mathrm{~g})$, and large numbers of chipped and ground/battered lithic artifacts $(n=11,670$; Table 7-1). Although it is likely that more were excavated, only a small quantity of burned rock was recovered $(n=366)$, and faunal remains were very sparse $(381 \mathrm{~g})$. Historic artifacts make up the last class of artifacts recovered from the site $(\mathrm{n}=82)$.

The vertical distributions of artifacts and ecofacts indicate a relatively complex depositional history (Table 7-2). The distribution of charcoal by weight has three peaks; a small peak in Level 6, a moderate peak in Levels 8 and 9, and a larger peak in Level 13. Mussel shell peaks are noted in Levels 5, 7, 9, and 11, while snail shell concentrations occur in Levels 3-5, 9, and 12-14.

Table 7-1. 1980 artifact recovery by unit

\begin{tabular}{|c|c|c|c|c|c|c|c|c|c|c|c|c|}
\hline Unit & 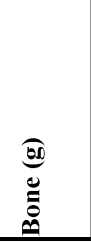 & 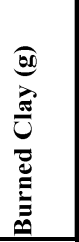 & 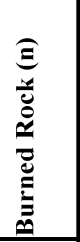 & 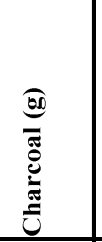 & $\begin{array}{l}\widehat{\Xi} \\
\vdots \\
\vdots\end{array}$ & 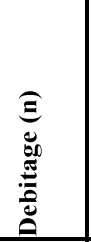 & 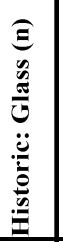 & 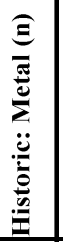 & 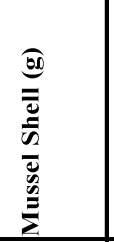 & $\begin{array}{l}\widehat{\Xi} \\
\stackrel{\Xi}{0} \\
\underline{0}\end{array}$ & 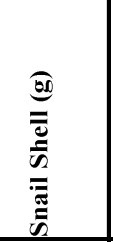 & $\begin{array}{l}\hat{\Xi} \\
\bar{\partial} \\
\hat{\theta}\end{array}$ \\
\hline $\mathrm{N} / \mathrm{A}$ & 0.00 & 0.00 & 2 & 0.00 & 0 & 11 & 0 & 0 & 16.60 & 2 & 0.00 & 4 \\
\hline 1 & 304.70 & 0.00 & 4 & 0.00 & 1 & 814 & 1 & 0 & 1374.06 & 1 & 2084.47 & 15 \\
\hline 2 & 9.33 & 5.77 & 33 & 98.97 & 1 & 1355 & 3 & 1 & 1443.40 & 0 & 441.08 & 11 \\
\hline 3 & 0.00 & 0.00 & 45 & 0.00 & 1 & 1353 & 62 & 6 & 364.99 & 1 & 1.50 & 10 \\
\hline 4 & 0.00 & 0.00 & 17 & 249.56 & 0 & 1645 & 0 & 0 & 912.60 & 4 & 8.80 & 10 \\
\hline 5 & 1.00 & 0.00 & 62 & 0.79 & 1 & 1100 & 0 & 0 & 814.31 & 4 & 3.50 & 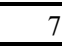 \\
\hline 6 & 2.18 & 0.00 & 32 & 0.00 & 0 & 663 & 0 & 0 & 411.90 & 0 & 6.20 & - \\
\hline 7 & 51.61 & 0.00 & 39 & 0.00 & 0 & 1791 & 0 & 0 & 785.30 & 1 & 1.10 & 10 \\
\hline 8 & 0.00 & 0.00 & 114 & 88.46 & 1 & 1631 & 3 & 0 & 462.83 & 2 & 0.00 & 15 \\
\hline 9 & 1.22 & 0.00 & 9 & 33.38 & 0 & 454 & 1 & 2 & 327.77 & 1 & 0.00 & 7 \\
\hline 10 & 11.40 & 6.50 & 7 & 13.14 & 0 & 420 & 0 & 1 & 77.67 & 3 & 0.00 & 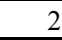 \\
\hline 11 & 0.00 & 0.00 & 1 & 0.00 & 0 & 180 & 1 & 0 & 99.40 & 1 & 0.31 & 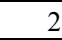 \\
\hline 12 & 0.00 & 0.00 & 1 & 0.00 & 0 & 57 & 0 & 1 & 31.29 & 1 & 0.00 & 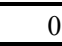 \\
\hline 13 & 0.00 & 0.00 & 0 & 0.06 & 0 & 42 & 0 & 0 & 65.43 & 0 & 0.00 & 0 \\
\hline 14 & 0.00 & 0.00 & 0 & 0.00 & 0 & 6 & 0 & 0 & 0.23 & 0 & 0.00 & - \\
\hline 15 & 0.00 & 0.00 & 0 & 0.00 & 0 & 27 & 0 & 0 & 20.48 & 1 & 0.00 & 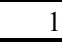 \\
\hline Total & 381.44 & 12.27 & 366 & 484.36 & 5 & 11549 & 71 & 11 & 7208.26 & 22 & 2546.96 & 94 \\
\hline
\end{tabular}

Note: N/A denotes unprovenienced artifacts 
Table 7-2. 1980 artifact recovery by level

\begin{tabular}{|c|c|c|c|c|c|c|c|c|c|c|c|c|}
\hline Level & 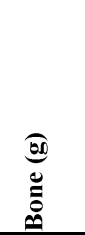 & 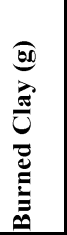 & 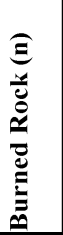 & 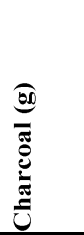 & $\begin{array}{l}\widehat{\Xi} \\
\vdots \\
\vdots \\
0\end{array}$ & 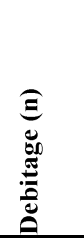 & 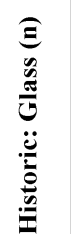 & 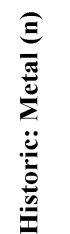 & 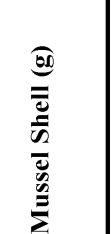 & $\begin{array}{l}\widehat{\Xi} \\
\stackrel{\Xi}{0} \\
\stackrel{\Xi}{0}\end{array}$ & 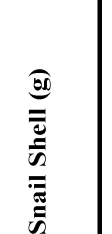 & $\begin{array}{l}\varrho \\
\stackrel{\Xi}{8}\end{array}$ \\
\hline N/A & 0.00 & 0.00 & 13 & 0.00 & 0 & 364 & 0 & 0 & 395.37 & 2 & 1.40 & 2 \\
\hline 0 & 0.00 & 0.00 & 2 & 0.00 & 0 & 0 & 0 & 0 & 0.00 & 2 & \begin{tabular}{l|l}
0.00 \\
\end{tabular} & 7 \\
\hline 1 & 9.33 & 0.00 & 1 & 0.06 & 0 & 253 & 67 & 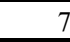 & 8.74 & 0 & 37.12 & 7 \\
\hline 2 & 2.13 & 0.00 & 1 & 0.00 & 0 & 285 & 0 & 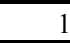 & 94.58 & 0 & \begin{tabular}{|l|}
85.95 \\
\end{tabular} & 2 \\
\hline 3 & 1.05 & 0.00 & 5 & 0.00 & 0 & 498 & 2 & 2 & 127.24 & 2 & 372.46 & 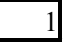 \\
\hline 4 & 25.77 & 0.00 & 14 & 0.00 & 0 & 604 & 2 & 0 & 166.45 & 0 & 221.12 & 2 \\
\hline 5 & 0.00 & 0.00 & 41 & 0.00 & 0 & 1290 & 0 & $\underline{0}$ & 940.34 & 0 & 237.98 & 11 \\
\hline 6 & 3.95 & 6.50 & 36 & 33.46 & 1 & 837 & 0 & 0 & 400.92 & 2 & 125.08 & 7 \\
\hline 7 & 4.22 & 0.00 & 74 & 10.92 & 1 & 1345 & 0 & 0 & 519.28 & 2 & 201.95 & 14 \\
\hline 8 & 26.63 & 0.00 & 36 & 89.30 & 0 & 1371 & 0 & 1 & 327.61 & 3 & 241.53 & 8 \\
\hline 9 & 306.22 & 0.00 & 22 & 72.60 & 1 & 848 & 0 & 0 & 1003.41 & 2 & \begin{tabular}{|c|}
760.10 \\
\end{tabular} & 12 \\
\hline 10 & 0.00 & 0.00 & 21 & 0.79 & 0 & 622 & 0 & 0 & 483.58 & 1 & 170.40 & 5 \\
\hline 11 & 2.14 & 0.00 & 46 & 0.00 & 1 & 2255 & 0 & 0 & 1691.37 & 4 & $\begin{array}{l}5.53 \\
\end{array}$ & 17 \\
\hline 12 & 0.00 & 0.00 & 33 & 48.18 & & 761 & 0 & 0 & 841.14 & 0 & 38.40 & 5 \\
\hline 13 & 0.00 & 5.77 & 17 & 201.38 & 0 & 140 & 0 & 0 & 126.48 & 2 & 20.20 & \\
\hline 14 & 0.00 & 0.00 & 4 & 27.67 & 0 & 61 & 0 & 0 & 72.76 & 0 & 27.74 & 1 \\
\hline 15 & 0.00 & 0.00 & 0 & 0.00 & 0 & 15 & 0 & 0 & 8.99 & 0 & 0.00 & 0 \\
\hline Total & 381.44 & 12.27 & 366 & 484.36 & 5 & 11549 & 71 & 11 & 7208.26 & 22 & 2546.96 & 94 \\
\hline
\end{tabular}

Note: N/A denotes unprovenienced artifacts

Animal bone peaks occur only in Levels 4 and 9 . The vertical distribution of burned rock and unmodified debitage exhibits three peaks. Peaks in the small quantity of burned rock collected in 1980 occur in Levels 5, 7, and 11, while debitage counts peak in Levels 5, 7-8, and 11.

Each of these artifact and/or ecofact categories represents different aspects of site use and its environs. In addition, they are each subject to collection and preservation biases. For instance, bone and charcoal are subject to differential preservation conditions, and the burned rock from the site was not collected systematically. Mussel shell may be a good indicator of food gathering intensity but snail shells may either reflect habitat characteristics or gathering practices or both. Finally, debitage densities reflect the intensity of lithic tool manufacture activities at the site and within the overall land-use strategy.

The 2002 excavations produced relatively large quantities of snail shells $(2,461 \mathrm{~g})$ and mussel shells $(674 \mathrm{~g}$; Table 7-3). Burned rocks $(\mathrm{n}=1,166)$ were also relatively common but overall not as numerous as what had been noted in the TxDOT excavation block north of FM 306. Only modest numbers of chipped lithic artifacts $(n=699)$ were recovered from the $5-\mathrm{m}^{2}$ excavation area. While snail shells and burned rock distributions have a bimodal pattern, mussel shells and unmodified debitage have single peaks but separated by some $30 \mathrm{~cm}$ (Table 7-4).

Table 7-3. 2002 artifact recovery by unit

\begin{tabular}{|c|c|c|c|c|c|c|c|c|}
\hline Unit & 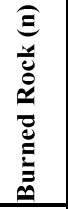 & 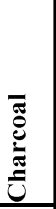 & 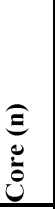 & 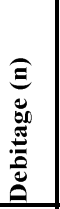 & 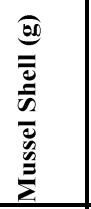 & $\begin{array}{l}\widehat{\Xi} \\
\stackrel{\Xi}{\Xi} \\
\stackrel{\Xi}{\Xi}\end{array}$ & 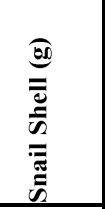 & $\begin{array}{l}\hat{\Xi} \\
\overline{0} \\
0\end{array}$ \\
\hline BHT 1 & 0 & 1 & 0 & 0 & 0.00 & 0 & 0.00 & 0 \\
\hline BHT 2 & 0 & 1 & 0 & 0 & 0.00 & 0 & 0.00 & 1 \\
\hline BHT 5 & 0 & 1 & 0 & 0 & 0.00 & 0 & 0.00 & 0 \\
\hline 20 & 641 & 2 & 0 & 341 & 64.46 & 0 & 1178.19 & 4 \\
\hline 21 & 142 & 8 & 0 & 195 & 193.74 & 2 & 286.46 & 0 \\
\hline 22 & 246 & 0 & 0 & 18 & 8.52 & 0 & 10.22 & 0 \\
\hline 23 & 137 & 0 & 0 & 136 & 406.96 & 0 & 986.06 & 2 \\
\hline Total & 1166 & 13 & 0 & 690 & 673.68 & 2 & 2460.93 & 7 \\
\hline
\end{tabular}


Table 7-4. 2002 artifact recovery by level

\begin{tabular}{|c|c|c|c|c|c|c|c|}
\hline Level & 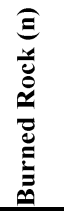 & 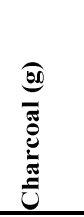 & 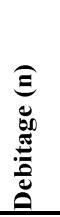 & 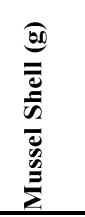 & $\begin{array}{l}\widehat{\Xi} \\
\stackrel{\Xi}{0} \\
\hat{\Xi}\end{array}$ & 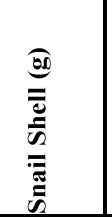 & $\begin{array}{l}\varrho \\
\stackrel{\Xi}{0}\end{array}$ \\
\hline $\mathrm{N} / \mathrm{A}$ & 0 & 293.40 & 1 & 0.0 & c & 0.00 & \\
\hline & 22 & 9.28 & 33 & 13.38 & 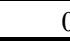 & 1.00 & \\
\hline & 437 & 0.00 & 108 & 64.5 & c & 180.36 & \\
\hline & 89 & 5.90 & 214 & 78.9 & 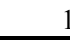 & 240.14 & \\
\hline 4 & 72 & 44.50 & 125 & 86.8 & 1 & 297.10 & \\
\hline 5 & 30 & 0.00 & 80 & 169.6 & c & 479.87 & \\
\hline 6 & 59 & 147.50 & 66 & 196.8 & c & 258.83 & \\
\hline 7 & 54 & 0.00 & 45 & 54.00 & c & 132.79 & \\
\hline 8 & 104 & 0.80 & 2 & 2.13 & c & 44.54 & \\
\hline 9 & 144 & 0.00 & 10 & 2.62 & c & 102.60 & \\
\hline 10 & 155 & 0.00 & 5 & 4.7 & c & 723.70 & \\
\hline & & 1.58 & 690 & 73.68 & & & \\
\hline
\end{tabular}

Note: N/A denotes unprovenienced artifacts

\section{Chipped Stone Artifacts}

A total of 11,670 chipped and ground/battered stone artifacts were recovered from the manual excavations at 41CM111 during the 1980 investigations. Unmodified debitage comprises 99 percent $(n=11,549)$ of the collection. The remainder of the chipped stone artifacts consists of projectile points $(\mathrm{n}=22)$, a bifacial adze, a single expedient scraper, miscellaneous bifaces $(\mathrm{n}=84)$, miscellaneous unifaces $(n=4)$, and cores $(n=5)$. The last two categories contain specimens that could not be classified into functional categories either because their manufacture was never finished, they are fragments that are too small for accurate classification, or they lack usewear indicative of a function. As a result, they are classified simply on the basis of the type of retouch they exhibit. A small metate fragment, a fragmentary mano, and a small hammer stone are the only ground/battered stone artifacts from the site.

A total of 699 chipped stone artifacts was recovered from the 2002 field investigations. Unmodified debitage comprises 98.7 percent $(n=690)$ of the collection. None of this material has been formally analyzed. The remainder of the chipped stone artifact collection consists of projectile points $(n=2)$ and miscellaneous bifaces $(n=7)$.

\section{Artifact Descriptions}

The chipped stone artifacts from 41CM111 include projectile points, an adze, an expedient scraper, miscellaneous bifaces, miscellaneous unifaces, cores, and flake debitage. Items in each of these categories are briefly described for the purpose of identifying details that subsequent discussions hinge upon.

\section{Projectile Points}

Given the role of projectile point typologies in assessing the age and associational integrity of deposits, in this section we examine the small collection $(n=24)$ of typed points from a rigorous typological perspective. Descriptive information on the projectile points, bifaces, and unifaces in the sample also are provided.

The following classifications were based on H. Shafer's typological assessments of the 41CM111 projectile point assemblage. The results are shown in Table 7-5. Overall, the small collection $(n=24)$ contains a relatively limited temporal range of types including Nolan, Pandale, Early Triangular, Andice, Bell, Langtry, and Martindale, along with three untyped specimens and one untypable dart point fragment.

\section{Andice-like ( $n=1$; Figure 7-1a)}

This specimen is badly damaged by direct impact. The edge of the base is missing, but the stem remnant shows steep notching flakes characteristic of Andice points. The blade has been extensively reworked, and the barbs, if once present, are missing.

\section{Bell ( $n=2$; Figure 7- $1 b$ and $c)$}

Both of these points fall well within the Bell type. Specimen 8H-001 (Figure 7-1b) has a long, narrow blade and one intact square barb; the other barb is broken. The stem is $17.75 \mathrm{~mm}$ wide and $13.51 \mathrm{~mm}$ long. The tip of the blade shows a burin-like fracture that could indicate an impact break. Specimen 10J (Figure 7-1c) has intact square barbs and a short, possibly reworked blade with a missing tip. The stem is $16.31 \mathrm{~mm}$ wide and $12.57 \mathrm{~mm}$ long.

Both points are unhesitatingly typed as Bell because of the stem morphology and square barbs. Prewitt (1983) correctly distinguishes Bell from Andice on the basis of 
Table 7-5. Distribution of dart points from 41CM111

\begin{tabular}{|l|r|c|r|c|}
\hline \multicolumn{1}{|c|}{ Description } & $\begin{array}{c}\text { Catalog } \\
\text { Number }\end{array}$ & Unit & $\begin{array}{c}\text { Depth } \\
\text { (cmbs) }\end{array}$ & Level \\
\hline Andice-like & 7H-001 & 7 & $70-80$ & 8 \\
\hline Bell & $8 \mathrm{H}-001$ & 8 & $70-80$ & 8 \\
\hline Bell & $10 \mathrm{~J}-001$ & 10 & $90-100$ & 10 \\
\hline Early Triangular & $0-002$ & - & 0 & 0 \\
\hline Early Triangular & $4 \mathrm{II}-001$ & 4 & $85-90$ & 11 \\
\hline Early Triangular & $4 \mathrm{I} 1-002$ & 4 & $85-90$ & 11 \\
\hline Early Triangular & $8 \mathrm{G}-001$ & 8 & $60-70$ & 7 \\
\hline Early Triangular & $15 \mathrm{~A}-004$ & 15 & $0-2 \mathrm{ft}$ & - \\
\hline Early Triangular & $21 \mathrm{C} 2-001$ & 21 & 27 & 3 \\
\hline Early Triangular & $21 \mathrm{D} 3-001$ & 21 & 33 & 4 \\
\hline Langtry & $3 \mathrm{C}-001$ & 3 & $20-30$ & 3 \\
\hline Martindale & $0-001$ & - & 0 & 0 \\
\hline Nolan & $10 \mathrm{I}-001$ & 10 & $80-90$ & 9 \\
\hline Nolan & $11 \mathrm{I}-001$ & 11 & $80-90$ & 9 \\
\hline Nolan & $5 \mathrm{II}-002$ & 5 & $68-73$ & 11 \\
\hline Nolan/Pandale & $4 \mathrm{II}-003$ & 4 & $85-90$ & 11 \\
\hline Nolan/Pandale & $5 \mathrm{JI}-003$ & 5 & $78-82$ & 13 \\
\hline Pandale & $5 \mathrm{~F}-001$ & 5 & $50-60$ & 6 \\
\hline Pandale & $10 \mathrm{M}-001$ & 10 & $120-130$ & 13 \\
\hline Pandale-like & $9 \mathrm{C}-001$ & 9 & $20-30$ & 3 \\
\hline Untypable Dart Point & $5 \mathrm{E}-001$ & 5 & $40-50$ & - \\
\hline Untyped Dart Point & $12 \mathrm{~F}-001$ & 12 & $50-60$ & 6 \\
\hline Untyped Dart Point & $1 \mathrm{G}-002$ & 1 & $60-70$ & 7 \\
\hline Untyped Dart Point & $4 \mathrm{G} 2-001$ & 4 & $70-75$ & 8 \\
\hline & & & & \\
\hline
\end{tabular}

stem length. Andice stem lengths have a range of 16-32 $\mathrm{mm}$ while Bell stems are less that $16 \mathrm{~mm}$ long. In his original definition of Andice, Prewitt (1983) notes that the two types intergrade and are often difficult to distinguish. He also regards the two types as belonging to the Calf Creek horizon (see also the discussion by Decker et al. 2000:224-227). The Bell component at the Richard Beene site has been dated to about $4500 \mathrm{BP}$ (Thoms et al. 1996).

\section{Early Triangular ( $n=7$; Figure 7-Id through $i$ )}

The attribute that separates these specimens from late stage preforms is the treatment of the lateral edges. The bases on all are thinned and the lateral edges are pressure flaked and many display serrations, or unifacially chipped serrations that result in a slight bevel, or simple pressure retouch. Specimen 21C2-001 (Figure 7-1d) is a small, complete triangular point, not serrated or beveled, but has pressure-retouched edges (probably from reworking). Specimen 8G-001 (Figure 7-1e) is a complete archetypical example of the Early Triangular type; its edges are serrated and a slight twist occurs on its right edge. Specimen 15A-004 (Figure 7-1f) has pressure flaked and serrated lateral edges. The tip is missing and one edge is damaged by impact. Specimen 4I1-001 (Figure 7-1g) is the stem portion of a point with minutely pressure flaked lateral edges. Specimen 4I1002 (Figure 7-1h) is a proximal fragment with some pressure flaking along both edges. This point is heavily heat spalled. Specimen 21D3-001 (Figure 7-1i) has a long, alternatively beveled blade and a distal impact fracture. Specimen 0-002 (not shown) is a proximal fragment that also displays pressure-retouched edges. It is post-depositionally broken.

All of the Early Triangular specimens were examined under a binocular microscope at 10-40X for evidence of use wear. This exercise was stimulated by the argument put forth by Black (Black and McGraw 1985:129-131) that thin-based Early Triangular bifaces were knives rather than projectile points as previous typologists had assumed. Their argument is based on the apparent reduction continuum from the initial triangular biface that resembles a Stage 4 preform to a final bifacially beveled form. They contend, based on the observations and experimental work of J. B. Sollberger (1971), that the beveling was a method of knife resharpening.

The 41CM111 sample does indeed contain specimens that unequivocally display high gloss use-polish and lateral retouch that removed some of that polish. Specimen 0-002 shows this the best exhibiting evidence of a high gloss polish and edge smoothing. Traces of polish on various surfaces or edges were noted on all seven of the Early Triangular projectile points examined. Given these findings, the argument certainly can be made that Early Triangular bifaces were knives, perhaps coeval with Bell-Andice points. Countering this unilateral function are examples of impact facture, supporting the argument that these are indeed projectile points. Our interpretation is that the Early Triangular specimens are most likely multifunctional tools that were used quite frequently as knives. The high gloss polish is consistent with meat cutting (c.f. Shafer and Holloway 1979). 


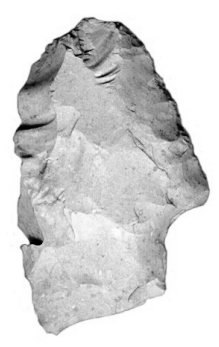

a

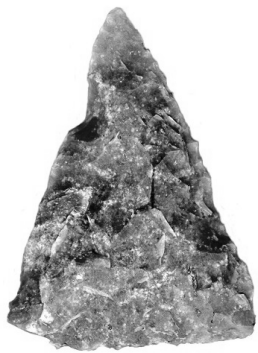

d

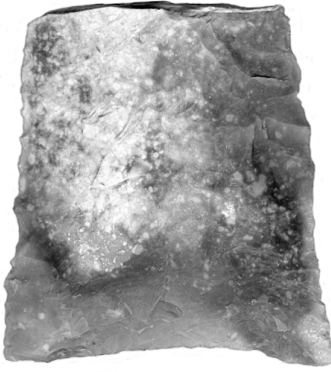

9

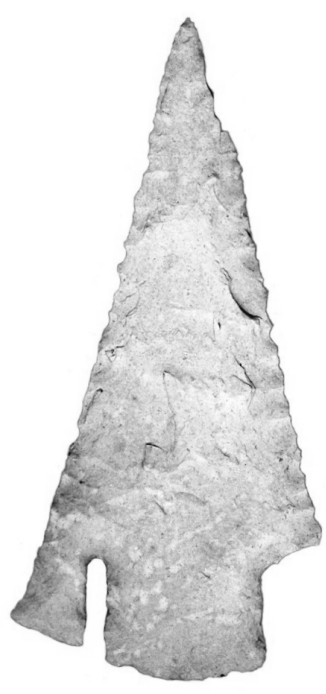

b

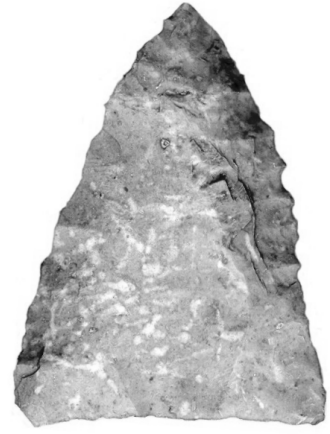

e

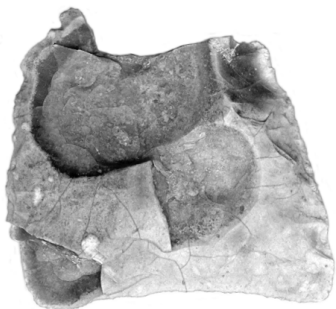

h

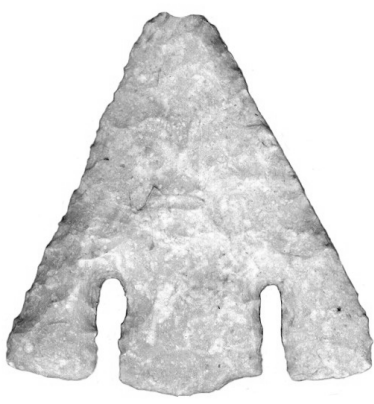

C
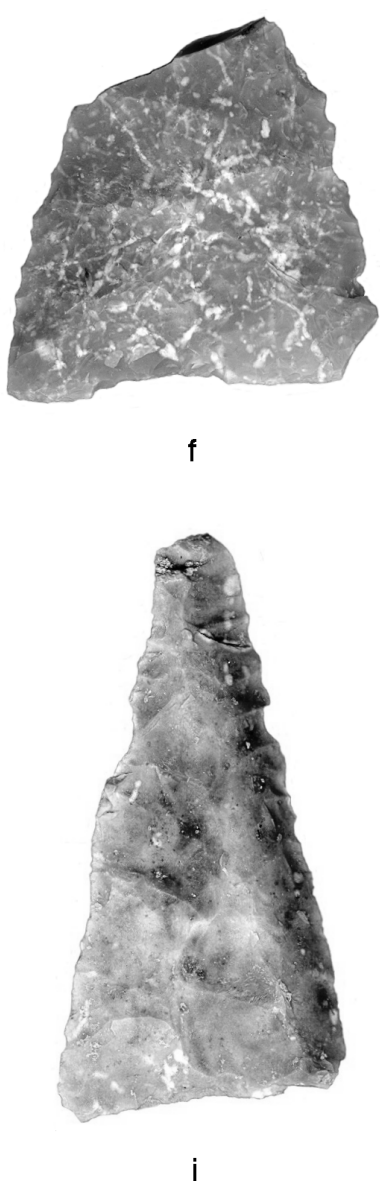

Figure 7-1. Dart points from 41CM111. a) Andice-like; b-c) Bell; d-i) Early Triangular. 


\section{Langtry ( $n=1$; Figure 7-2a)}

This point, with a slightly contracting stem, indented base, prominent shoulders and thin blade, fits well within the classic Lower Pecos archetype (see Dibble 1967:Figure 21). Langtry points occur as a minor MiddleLate Archaic type as reported along the eastern fringes of the Edwards Plateau (Black and McGraw 1985:115, Figure 20g-I; Decker et al. 2000:225, Figure 151c-g). Decker et al. include Langtry in their Late Archaic I temporal segment. Johnson (1995:226-228), however, is reluctant to use the term Langtry for broad-bladed contracting stem points from the Jonas Terrace site in Medina County.

\section{Martindale ( $n=1$; not shown)}

This point has a fishtail base characteristic of the type. Evidence of small barbs is present, but the blade is badly damaged by direct impact with bending flake terminations extending up the surviving portion.

\section{Nolan ( $n=3$; Figure $7-2 b$ and $c$ )}

Classic Nolan points have approximately square stems with steep beveling of the right stem edges, weak to moderate shoulders, and triangular blades often slightly recurved to create a needle-like tip. Specimen 10I-001 (Figure 7-2b) fits that description well. This complete specimen was made on a triangular preform, has the characteristic alternately beveled stem, and the blade was resharpened as indicated by flakes intersecting thinning flake scars. Specimen 5I1-002 (Figure 7-2c) has a stem slightly beveled to the right, weak shoulders, and a short blade reduced in size by reworking and reshaping. Specimen 11I-001 (not shown) lacks most of the stem and tip, but the stem remnant is steeply beveled to the right. The blade is broad and has a slight twist to the left from pressure flaking.

\section{Pandale ( $n=2$; Figure $7-2 d$ and $e$ )}

Both of these points have attributes of the Pandale type in addition to the overall outline. Specimen 5F-001 (Figure 7-2d) fits the archetype well (cf. Suhm et al. 1954:464; Dibble 1967:Figure 22) with a twisted stem and markedly twisted leaf-shaped blade. The complete point is relatively thick $(10.3 \mathrm{~mm})$ and heavy $(26 \mathrm{~g})$, and this may be the ultimate reason for discard. Specimen 10M-001 (Figure 7-2e) displays a noticeable twist on the remnant of the blade; the blade was severely smashed by impact. The stem on this specimen, however, is not twisted to the right as commonly occurs on the Pandale archetype.

\section{Pandale-like ( $n=1$; Figure 7-2f)}

This specimen, 9C-001, has the outline of a Pandale archetype. The stem is slightly expanding, the base is straight, and the blade is narrow and has rounded shoulders. A small segment of the tip is missing. It lacks any evidence of a twist to either the stem or blade. The point is classified here as a Pandale-like merely on the basis of outline, which differs from both Nolan and Travis by the stem morphology and rounded shoulders.

Nolan/Pandale Variants ( $n=2$; Figure $7-2 g$ and $h$ ) Both of these specimens have the shared characteristic of a long, narrow beveled or twisted blade. The bevel or twist is on the left edge. The stem on specimen 5J1-003 (Figure 7-2g) is parallel sided with a straight base. No beveling occurs on the stem; shoulders are slight. The outline of this specimen would fit the Travis type were it not for the beveled or twisted blade. The second specimen (4I1-003; Figure 7-2h) is similar, albeit with a more twisted blade and shoulders that are virtually absent. The square stem is beveled on the right on one side only. Overall, the outline of this specimen also is more Travislike were it not for the narrow, twisted blade.

\section{Untyped Dart Points $(n=3)$}

None of these points fits any defined type cleanly. Therefore, each will be described separately.

Untyped, parallel stem $(n=1$; not shown) A long, parallel sided stem, faintly convex base, and weak shoulders define this point (12F-001). The base is wedgeshaped in profile. The attributes make the point difficult to classify, but it compares closely to similar specimens described as Bulverde-like (Sorrow et al. 1967). Conceivably, the stem could be from a reworked Andice, but there is no hint of blade reworking that might suggest this type.

\section{Untyped, long contracting stem}

$(\mathrm{n}=1$; Figure $7-2 \mathrm{i})$

This point has a long, tapered stem with a convex base (4G2-001). The blade is leaf-shaped, but not beveled or twisted. In outline, it falls in the Nolan-Pandale series, but lacks diagnostic attributes of both types. The stem 


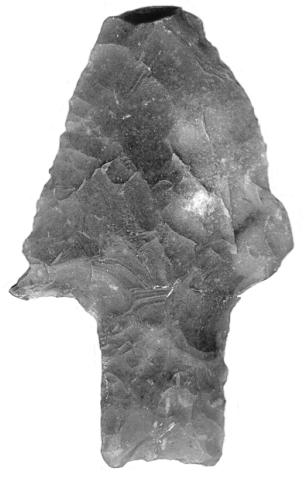

a

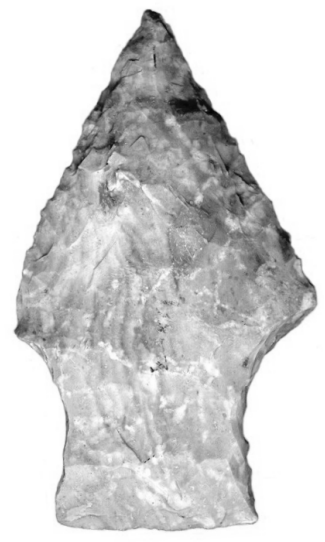

b

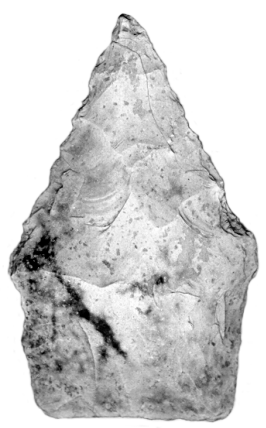

c

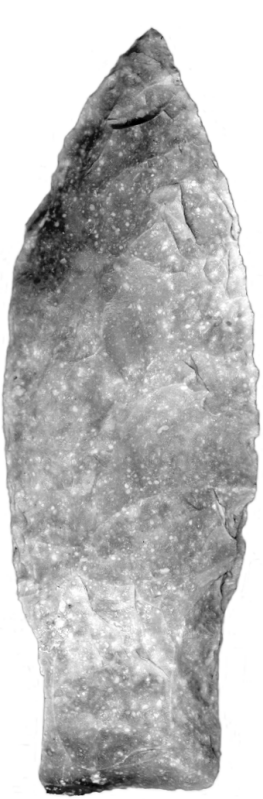

d

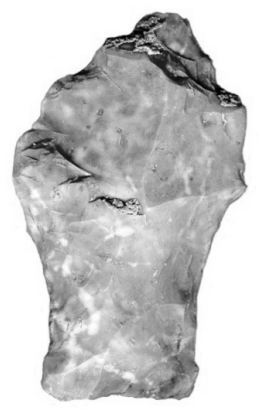

e

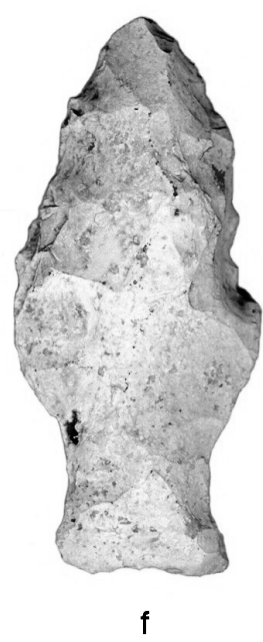

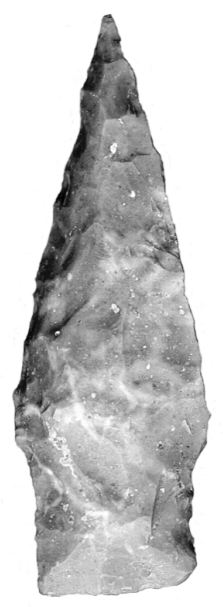

g
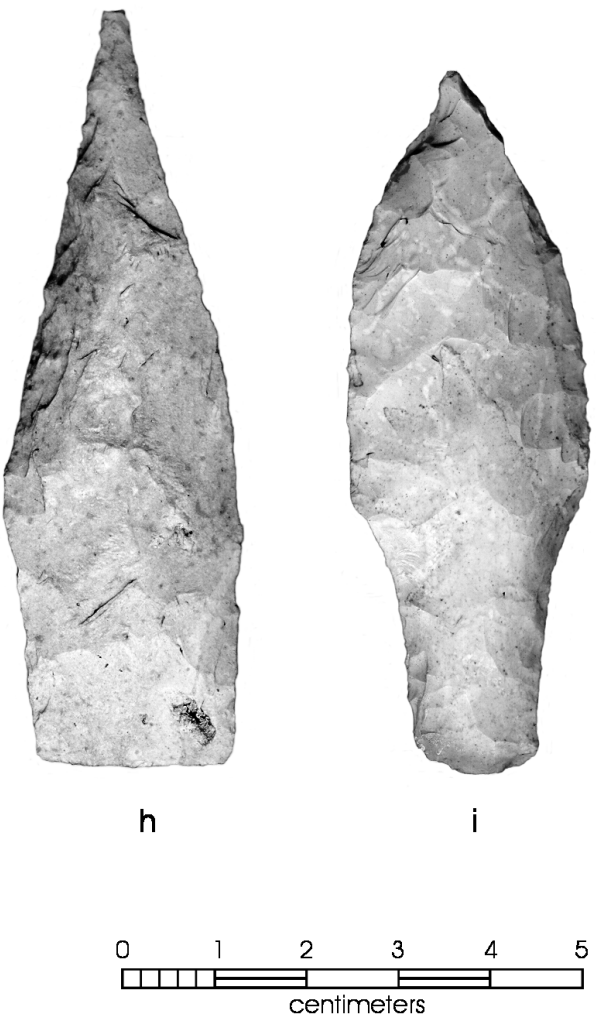

Figure 7-2. Additional dart points from 41CM111. a) Langtry; b-c) Nolan; d-e) Pandale; f) Pandale-like; g-h) Nolan/Pandale variants; i) untyped long contracting stem. 
seemingly fits Nolan in outline while the leaf-shaped blade is characteristic of Pandale.

Untyped, side-notched ( $\mathrm{n}=1$; not shown)

This point is probably an anomaly (1G). It fits into the more side-notched Lower Pecos varieties of Ensor (Dibble 1967:Figure 15), but not the more corner-notched varieties generally characteristic of Central Texas (Miller and Jelks 1952).

Untypable Dart Point Fragment ( $n=1$; not shown) This short stem fragment has parallel to slightly expanding edges and a straight base (5E-001). It is broken at the neck and the break morphology suggests that it was broken in use.

\section{Elongated Bifacial Adze (n=1; Figure 7-3a)}

This artifact is a well-made, elongated, thinned biface with rounded distal ends. One end is very sharp as the result of fine pressure retouch applied unifacially. The opposite end is not as well finished. Lateral edges are mildly dulled, perhaps from hafting. The tool appears to be a specific kind of adze; two almost identical specimens were reported from the Woodrow Heard site and described as "Stage 4 knives" from the Angostura component (Decker et al. 2000:Figure 210). Traces of microscopic use-wear on one of the Woodrow Heard specimens were suggestive of knife wear according to the authors, but from this researcher's experience (Shafer), haft wear could also be misconstrued as knife wear. More attention should be focused on the ends of these tools rather than the lateral edges.

\section{Expedient Scraper $(n=1)$}

A single small decorticate flake fragment exhibits one edge with minute flake scars resulting from use. The microflaking is consistent with the use of the specimen as a scraper. Given the lack of resharpening retouch, the specimen can be defined as an expedient tool (i.e., no cost in manufacturing the tool).

\section{Miscellaneous Bifaces $(n=91)$}

A total 91 miscellaneous bifaces was recovered from 41CM111. These specimens consist of a combination of manufacture broken fragments, complete specimens that were discarded due to failure to properly thin the item, fragments that were too small to securely classify into functional categories, and manufacture-failed specimens that probably represent projectile point preforms. The specimens that fall into the last group, the projectile point preforms, are of greatest interest to us because they can inform us both about projectile point manufacture technology as well as overall site use.

All complete bifaces and fragments other than projectile points were examined for both technological and typological information. Technological information included reduction stage, reasons for rejection (such as a premature break), manufacture mistakes (loss of platform, repeated hinge or step fracture), or material flaw. Types of breaks, such as snap, perverse, or overshot, were also noted. Of specific interest was the identification of bifaces or tools that might relate to the Early Triangular component at the site. The diagnostic criteria taken into consideration included the relative shape of the biface, its stage of reduction, and such attributes as basal thinning and beveling.

Commonly, bifaces are grouped according to approximate stage of reduction or manufacture. Following a linear reduction model, biface reduction begins with a core, either a suitably-sized cobble or a large flake selected for the purpose. As reduction proceeds, bifaces become thinner and assume the shape of the final product. Breakage can occur at any stage along the trajectory, fossilizing that stage of the trajectory. The stage model used by Goode (2002:87) and Andrefsky (1998:Figure 7:31) is not precisely followed in this report. Their Stages 1 and 2, or early and middle reduction stage bifaces, are considered blanks that could follow one of several trajectories if finished. That is, blanks have generalized shapes that could be finished into one of several point types but the final point type they will be made into is not self evident on the blanks. On the other 


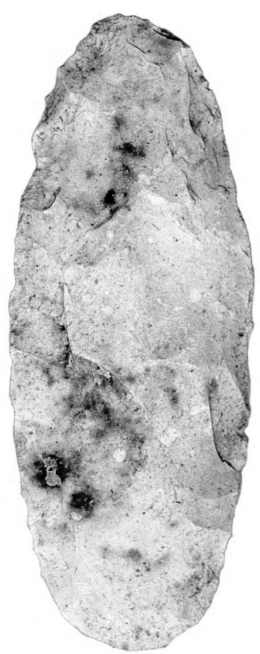

a

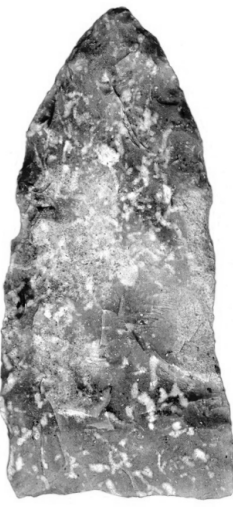

d

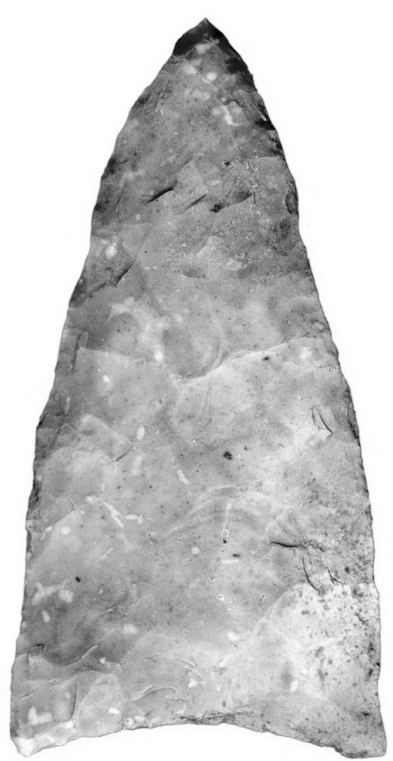

b

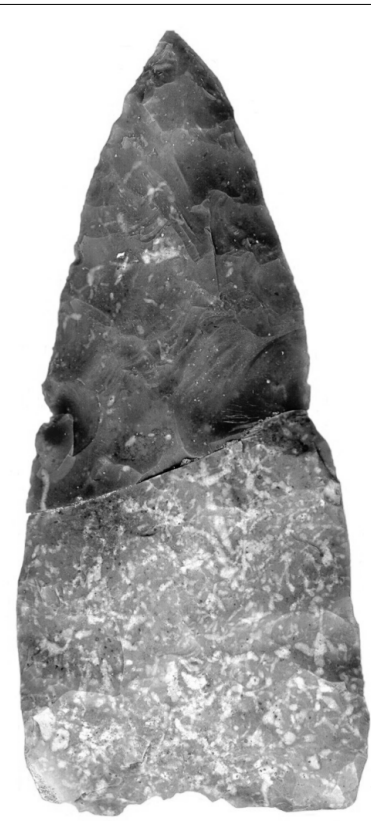

C

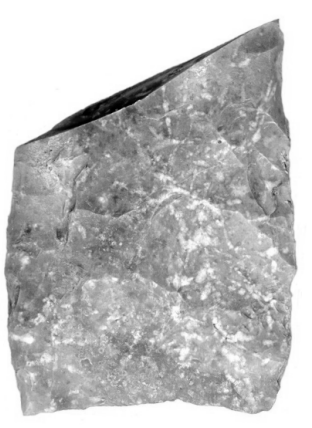

e

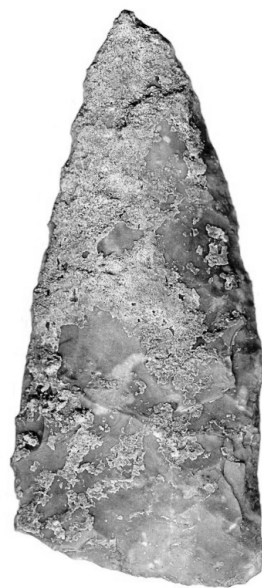

$f$

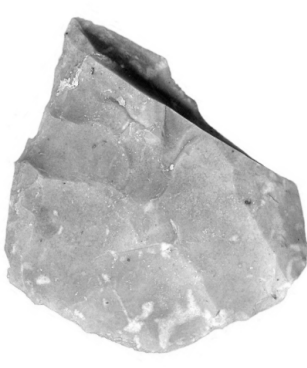

g 
hand, the reduction of preforms has progressed so far along the manufacture trajectory that the projectile point types being manufactured from them can be identified. This distinction between blank and preform follows that proposed by Bradley (1975). In the 41CM111 collection, some of the bifaces that have reached the late stage of reduction (i.e., Stages 3 or 4 in Goode's and Andresfky's model) have sufficiently well-defined morphological characteristics to be classified as either Nolan/Pandale, Andice/Bell, or Early Triangular projectile point preforms. This is not to say that some of the remaining bifacially flaked artifacts were not intended as projectile points. However, because they were discarded early in the reduction sequence, they do not retain sufficient diagnostic criteria to unequivocally identify them as projectile point preforms. Finally, only complete specimens and manufacture-failed proximal fragments were classified as preforms since they retained the stem/ base portion of the artifact.

One important characteristic stands out in this samplethe low frequency of early reduction stage bifaces (i.e., Stage 1). Only 67 of the bifaces and biface fragments could be classified into stages of reduction. There are only $14(16 \%)$ Stage 1 or early reduction stage bifaces in the collection. Middle reduction stage bifaces (Stage 2) are more common with a total of 21 (23\%) specimens in the sample. Late reduction stage (Stages 3 and 4) bifaces are nearly as common $(n=32 ; 36 \%)$ as early and middle reduction stage specimens combined $(n=35)$. Twenty (62.5\%) of the late reduction stage fragments can be considered preforms based on their morphological similarities to typed specimens.

The low number of Stage 1 or early reduction stage bifaces is attributed, in part, to the probable paucity of chert in this immediate locality. The chert-free Glen Rose Limestone dominates the local geological deposits; the later Edwards Limestone contains an abundance of high quality chert and outcrops downstream from the site. Archaic sites, such as the John Ischy site located at a high quality chert source (Sorrow 1969), typically contain an abundance of corticate debitage and early reduction stage bifaces. Apparently, most reduction at 41CM111 occurred from Stage 2 bifaces that were transported to the site, probably as mobile furniture by hunters. All but one of the bifaces is made of chert from Edwards Formation limestones. Two specimens (8G-001 and 2G1-014) have traces of brown cortex characteristic of stream gravels, indicating that stream gravels were also exploited for chert by the site's occupants. The single non-chert specimen is a narrow, late reduction stage biface fragment made of Catahoula sandstone that outcrops in the Cenozoic Catahoula Formation (Sellards et al. 1958:710-727). Chandler and Lopez (1992) describe a quarry outcrop of quartz arenite in Duval County in south Texas, but the material in question is a fused sandstone consistent with Catahoula sandstone.

As indicated above, the majority (62.5\%) of the late stage (Goode's Stages 3 and 4) bifaces from 41CM111 represent projectile point preforms. In general, the manufacture of the preforms terminated in breakage but a handful of specimens remained complete-although they exhibit manufacture difficulties that prevented them from being finished into usable points. Within preforms, the most frequent type of break is a snap fracture caused by end shock. End shock occurs when a blow struck near one end sets up vibrations that exceed the elastic limits of the material causing a snap fracture about midpoint in the blade (Crabtree 1972:60). The excessive vibrations are often due to improper stabilization during the blow. This is one of the more common types of failure in the late stages of biface manufacture, due to the fact that much of the mass that would otherwise sustain the vibrations had been removed. The snap fracture is usually at a right angle to the edge, but may be transverse to the edge or have a bird's foot pattern resulting in more than two pieces. Material flaw is the second most common reason for failure. These flaws are of two kinds: natural flaws in the material such as a quartz-filled fossil void which occurs in certain fossiliferous cherts found at the site, or by a crack resulting from an early stage mistake. Other reasons for failure include platform collapse or loss of platform due to repeated step and hinge fractures, loss of shape due to attempts to remove a problematic area, and perverse fractures. Perverse fractures are spiral or twisted breaks that occur when the fracture path curves into the mass rather than following the surface (Crabtree 1972:82).

\section{Rejected Projectile Point Preforms}

Although 20 late stage bifaces and biface fragments were identified as preforms in the collection, identifying the finished projectile point types represented by these preforms was by no means an easy task. The key attributes 
used to assign these late stage bifaces to a given projectile point type (cf. Bradley 1975) was the degree of morphological and technological similarity to finished examples of point types present at the site. For instance, Early Triangular points are consistently manufactured with concave bases while Bell/Andice forms are typically straight based, although an angled base may often be used to give the barbs the angled look typical of Bell points. Similarly, while the bases of Early Triangular forms are well-thinned, primarily in the center of the base, Andice/Bell forms tend to be well-thinned along their entire basal width to allow the chipping of the long basal notches that are characteristic of the type. In addition, since the Andice/Bell and Early Triangular points characteristically are well-thinned and have broad blades, the preform trajectory for these types should be somewhat different from the more narrow bladed and often thicker Nolan/Pandale series. And finally, Nolan/ Pandale points are typically made with straight to slightly convex bases rather than concave bases characteristic of Early Triangular points.

Based on these diagnostic criteria, 17 (85\%) triangular specimen fragments with broad stems and concave bases have been classified as Early Triangular preforms (see Figure 7-3b through 7-3e for examples). Two (10\%) of the 20 preforms and preform fragments characterized by narrow and thick stems and convex bases are classified as Nolan/Pandale preforms (see Figure 7-3f, one shown). One specimen (5\%) with a convex but somewhat angular base has been classified as a Bell preform (Figure 7-3g).

\section{Miscellaneous Unifaces $(n=4)$}

Overall, the uniface collection is nondescript and lacks the more diagnostic side or end-retouched flakes fitting recognized uniface tool types (e.g., oval flake unifaces or end scrapers). Some of the items classified as unifaces may represent flakes minutely trimmed and damaged by trampling (McBrearty et al. 1998). Given the fact that experimentally trampled flakes and "utilized flakes" exhibit identical types of edge damage, it is not possible to determine from an individual specimen which of the two processes caused the damage.

The examination of the unifacial artifacts yielded only one possible tool (3E-001). This is a large, elongated flake-blade with marginal (unifacial) retouch on one edge and limited retouch on the opposite edge. Edge damage from use suggests coarse, knife-like wear. A drawing motion is suggested by the diagonal trajectory of microflakes removed from the edge during use.

\section{Cores $(n=5)$}

Cores are masses from which flakes have been removed, and technically speaking, can include all bifaces and unifaces. This group of cores, however, consists of residual items discarded or rejected during the course of reduction. The sample of cores only numbers five specimens. Two (2F-002 and 1I1-005) are fragments of cores whose trajectory was to obtain flakes - one is an interior segment and the other is part of a stream-rolled cobble. Two complete cores (3I2-001 and 5I1-010) also fall into the flake trajectory category. Both are extensively reduced, stream-worn cobbles and the scars show evidence of multiple platforms. The remaining specimen (8G-015) is a small, triangular nodular fragment of primary source material that has a few small flakes removed. No functional assessment can be made of this piece.

Three of the cores made on stream-worn cobbles appear as though they may have been heat-treated. The oxidized cortex indicates they were heated, but it is not possible to tell if this was intentional or incidental.

The paucity of cores of reduced primary material and the representation of tabular nodules clearly selected for their suitability for biface production are further indications that primary chert resources were not readily available. How far these specimens were transported is unknown, but the patterns recognized in the core sample do not contradict those observed in the preform and debitage samples. This pattern is one of transient mobility where small mass items are brought to the site for final reduction and finishing as part of retooling hunting kits.

\section{Flake Debitage}

Debitage is the debris produced during the course of chipped stone tool manufacture. It includes residual flakes, shatter, microdebitage, rejected cores, broken and/or discarded hammer stones, and production failures including the preforms described previously. The value 
of analyzing flake debitage has been debated by Johnson (1995). The arguments are justified, in part, due to numerous reports that provide detailed descriptive information about flake debitage without purpose, so to speak. Our argument on the value of flake debitage analysis is that analysis should be problem driven (Andrefsky 1998:110-135). Flake debitage analysis is hardly standardized in Texas site reports so there are no standards to guide the analyst. Knowledge of fracture mechanics and recognizing subtle nuances of flintknapping are essential skills for the analyst. The "free standing typology" (Andrefsky 1998:122) of Sullivan and Rosen (1985) is hardly recommended, since this approach, which is widely used in the American Southwest, requires no knowledge of fracture mechanics and overlooks variability in biface and uniface technologies, the very things that serve to identify change.

Debitage (flakes, cores, biface failures) constitutes part of site trash that is generally left at or near the location where flaking occurred. Biface preforms may be transported from site to site in tool kits (see Shafer 1986:105 for an example) and end up some distance away from the location in which they were produced. As site trash, flake debitage provides an indelible record of the range of in situ flaking activities carried out on site, and contribute information to activity analysis. By teasing out the nuances of reduction strategies and trajectories, the skilled analyst may be able to determine the kinds of tools made and the reduction techniques used to make them. This information alone is worthy of the effort, and when different components are compared temporally and spatially, fundamental changes in flintknapping traditions may be recognized (Shafer 1979). In addition, flake distribution, especially microdebitage, can reveal specific loci of production even if the bulk debitage has been removed (Clark 1991), or may demonstrate in situ formation of chipping residue deposits when bulk residue is not removed (Shafer and Hester 1986). Refitted pieces provide valuable information on the integrity of the deposits and site formation processes (Hofman 1992; Stackelbeck 2000). Clusters of refitted pieces demonstrate, for example, that surface disturbances were minimal at a site and did not adversely affect the integrity of the deposits. Vertical movement of refitted pieces, however, suggests either cultural or natural turbation of the deposits as a factor.
Because we were uncertain of the integrity of the deposits and the possibility of identifying isolable deposits, for descriptive and analytical purposes, debitage from only two excavation units (N80/E200 and N106/E200) was analyzed for this report. Unit N80/E200 (Unit 8 in Figure 5-2) is located on the south side of FM 306 while unit N106/E200 (Unit 3) is on the north side. The flake debitage attributes analyzed here included material, completeness, flake type, and presence of cortex. All of the examined pieces are of chert. Flake types are related to reduction trajectory and sequence. For example, cortex flakes removed by hard-hammer percussion were labeled core/platform preparation indicating they are the residue from either core reduction or platform preparation where a hard hammer was required. Biface thinning flakes display the characteristic bending or lipped striking platform indicative of soft percussor (billet or punch) removal. Biface manufacture flakes lack the characteristic lipped platform, but possess all other characteristics of biface thinning flakes such as arched, thinned profiles and multifaceted exterior surfaces. The majority of the "indeterminate" flakes fall into this category as well, but were not so classified here due to their fragmentary state. Blades are defined as being over twice as long as they are wide and struck from prepared cores, or are fragmentary but have parallel flake scars and ridges. Blades are rare in Central Texas Archaic components, and blade technology is not characteristic of Archaic assemblages in Central Texas. Therefore, most blades were either fortuitous or were struck for specific kinds of tools. Uniface flakes display a unifacially trimmed edge and are presumed to be flakes of uniface retouch. However, given the near absence of unifaces in this assemblage, it is likely that most of these flakes were struck from flake cores with unifacially trimmed platforms. Conversely, it could indicate that unifaces have been removed from the site or were discarded in unexcavated portions of the site.

Presence or absence of cortex also was coded. Flakes and fragments were categorized into specimens with 1-50 percent cortex, 51-99 percent cortex, 100 percent cortex, and flakes lacking cortex entirely (decorticate flakes). Within the N106/E200 debitage sample, only seven percent $(n=103)$ of the debitage has any cortex, while only 10 percent $(n=166)$ of the debitage from N80/ E200 is corticated. In both samples, specimens with 
1-50 percent cortex dominate the corticated samples (N106/E200, 74\%, n=76; N80/E200, 69\%, n=115). Figure 7-4 suggests that south of FM 306, the percentage of debitage with any cortex is most common in the upper levels (2-5) and the deepest level (10) of unit N80/E200. There is a smaller peak in corticated debitage in Level 7 of the unit. North of the road in unit N106/E200, the most prominent peak in corticated debitage is in Level 7 , although a smaller peak also occurs in Level 3. These patterns may be indicative of differences in lithic procurement strategies over time as related to the transportation of decorticate and corticate raw materials and/ or blanks to the site.

The biface sample strongly suggests most bifaces were brought to the site as Stages 3 or 4 preforms. If this was indeed the case, then the flake debitage should be heavily represented by flakes produced during late stages of reduction or biface thinning. In other words, a high percentage of biface thinning and interior or decorticate flakes, and low percentages of corticate flakes, would be expected.

Figure 7-5 shows the vertical distribution of biface thinning flakes within the two units. In unit N80/E200, the percentage of thinning flakes shows two peaks, one in Level 3 and the other in Levels 6 and 7. In Level 5, thinning flakes represent only six percent of all the flakes that could be classified by flake type. On the north side of the road, as represented by unit N106/E200, biface thinning flakes in general represent a higher proportion of the samples than in the case of unit N80/E200. Peaks in the percentage of biface thinning flakes occur in Levels $1,3,6$, and 9 .

The patterns noted in Figures 7-4 and 7-5 seem to confirm the suggestion that a significant percentage of the raw material arrived at the site in decorticate form or as biface blanks and perhaps preforms. Chert types examined (but not sorted) on the basis of color and texture favored high quality Edwards material ideal for biface manufacture. The variability in cortex (white, lacy cortex compared to rusty brown, battered, stream-rolled cortex) suggested procurement from both parent outcrops and old gravels that contained the parent outcrop material. While variability in chert types is not as great as might be expected for a short occupation span campsite, the lack of variability in the cherts could either be due to local knowledge of where such material was available, or that selection represents only what was available in the site's proximity. The bias toward flakes produced in biface thinning could also indicate the resident population was indeed only moving through the area and that retooling involved finishing bifaces brought to the site primarily in Stage 2 blanks or Stages 3 or 4 preforms, or that the availability of raw material was some distance away and mostly blanks rather than naturally occurring nodules were brought to the site. Either of these scenarios is possible, of course, but the latter is regarded as the more likely of the two.

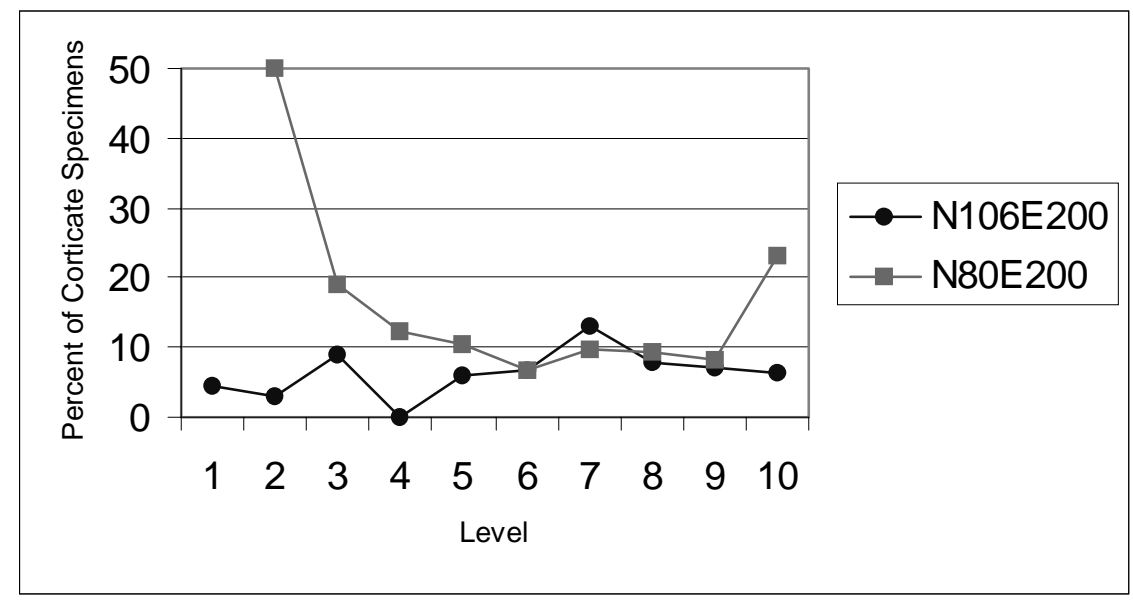

Figure 7-4. Distribution of corticate debitage by level within units N80/E200 and N106/E200. 


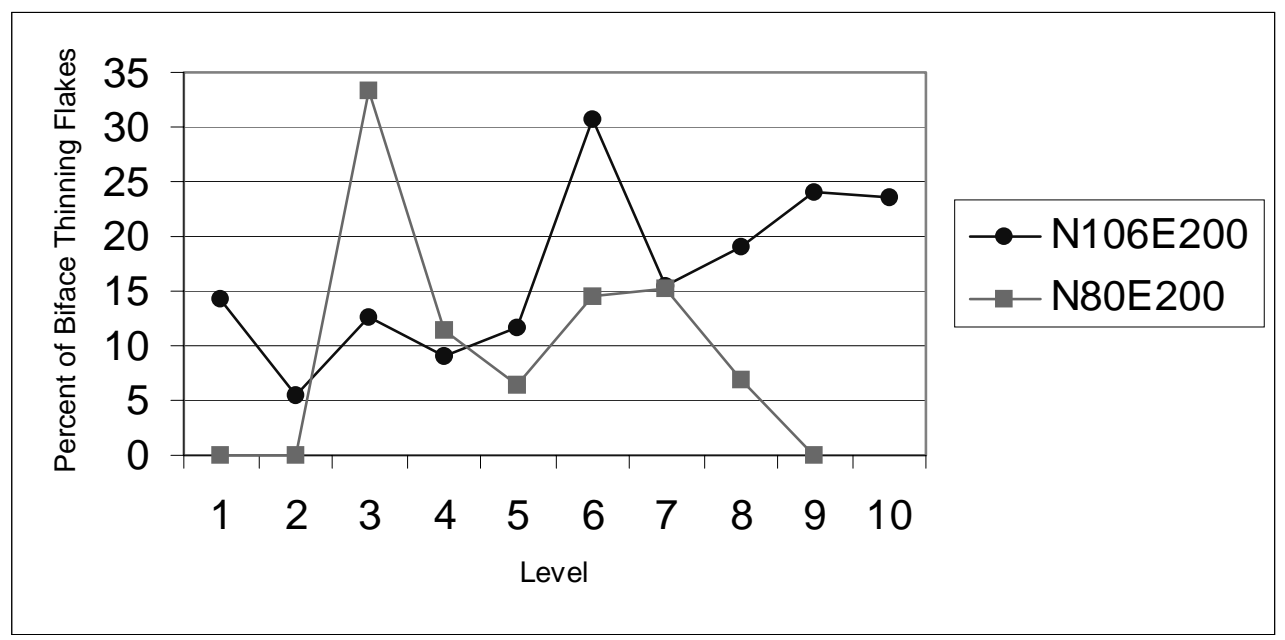

Figure 7-5. Distribution of biface thinning flakes by level within units N80/E200 and N106/E200.

\section{Feature Descriptions}

The primary feature encountered during the course of the two excavations was a burned rock sheet midden, here termed a macrofeature. Figure 1-3 depicts the extent of the burned rock across the entire block at Level 7, excluding Unit 1, N106/E196. This stratum of burned rock was the only indication of a former living surface. Contained within this macrofeature were several possible disturbed hearth features; however, their presence was nebulous at best and, lacking delimiting bounds, were unable to be recognized as discrete features within the sheet midden. One exception, though, was the encounter of an unambiguous rock-lined hearth (Feature 3) clearly discernible in the northern portion of the midden (see Figure 1-4).

Regardless the ill-defined manifestation of these early features, their individual descriptions are here warranted. As previously stated, these features probably represent denser concentrations of burned rock within the larger sheet midden. Yet, it remains possible that the features recorded in the 1980 field efforts are indeed dispersed hearths or burned rock clusters, now constituents of the burned rock sheet midden.

A total of six features was recorded during the 1980 field investigations. While formal feature forms were not utilized, combining the lot indices, field director's journal, and the individual unit level forms allows the reconstruction of the features. Half of the anomalies recorded as features (nos. 2, 4, and 5) are in all probability non-features or burned rock specimens derived from highly disturbed features. The remainder of the recorded features (nos. 1, 3, and 6) are all burned rock features associated with the midden, identified by the crew as Level 7.

Feature 1 was recorded within the buried living surface encountered in Unit 1 (N106/E196). The feature was initially categorized as a burned rock concentration associated with Level 7. This feature would later be associated with Feature 3, a large hearth. Feature 1 was never defined as possessing any distinct boundaries, rather it was described as a scatter of burned rocks across the entire floor of the unit level.

Feature 2 was described as an anomaly of burned rock and few lithic debitage. According to the unit level forms (Unit 2, N106/E198, Levels 2 and 3, 24 March 1980), only 11 flakes, sparse mussel shell, and an indeterminate amount of burned rock were recovered from the feature. Due to its vertical provenience, however, it is most likely that this feature occurs as a result of road construction activities.

The third feature is a large $(100 \mathrm{~cm}$ diameter $)$ cluster of burned rock, and is interpreted as a hearth (see Figure 14; unit level form, Units 2 and 3, N106/E198 and N106/ E200, Level 7, 26 March 1980). An indeterminate 
amount of burned rock was contained within Feature 3; however, the paleosol as expressed within the block excavation is replete with similar burned limestone rocks.

A small (20 cm diameter) pit feature was encountered in Level $3(20-30 \mathrm{cmbs})$ of Unit 3, N106/E200, and recorded as Feature 4. The contents of the feature were comprised mainly of small gravels, with only three pieces of lithic debitage and sparse land snail shell (daily journal, 27 March 1980). Similar to Feature 2, due to its vertical provenience, it is most likely that this feature occurs as a result of road construction activities.

Feature 5 was encountered in Unit 3, N106/E200, within the same level (3) as Feature 4. The two features are separated by less than $30 \mathrm{~cm}$ and are in similar proximity to a large slab of limestone. The 1980 project archeologist speculated as to whether these three anomalies are the result of some form of disturbance (daily journal, 27 March 1980). It is likely that the three anomalies are indeed the result of road construction activities.

A sixth feature number was assigned to a diffuse scatter of burned limestone in Level 6 of Unit 3, N106/E200. Feature 6 was recorded within the paleosol encountered in Unit 3. This feature would later be associated with Feature 3, a large hearth. Feature 6 was never identified as possessing any definable boundaries, rather it was described as a scatter of burned rocks across the entire floor of the unit level (unit level form, 01 April 1980).

Feature 7 was the single definable cultural feature encountered in the 2002 investigations. Interpreted as a large burned rock hearth, the diameter was approximately $150 \mathrm{~cm}$ (Figures 7-6 and 7-7). The materials were encountered during mechanical excavation of BHT-2, located south of FM 306 (see Figure 5-2). The feature was first encountered at approximately $40 \mathrm{cmbs}$, with the majority of the materials occurring between 50 and 85 cmbs. The single charcoal sample submitted for radiometric dating (Beta no. 166720) was procured at $56 \mathrm{cmbs}$ and is judged to come from reliable context. The arrangement of the materials was peculiar in that the concentration of burned rocks lay to one side, while the charred wood and ashy material lay to the opposite side (Figure 7-6). The burned limestone rocks contained within this feature exhibit rough, angular exterior surfaces. As opposed to the smooth, rounded and subrounded surfaces of fluvial transported stones located in the adjacent tributary (see Figure 2-4), the feature rocks most likely were procured from the adjacent landform or colluvium there from.

Aside from the single hearth feature (Feature 7), the 2002 excavations yielded a relatively insignificant amount of burned limestone. The thin scatter is probably

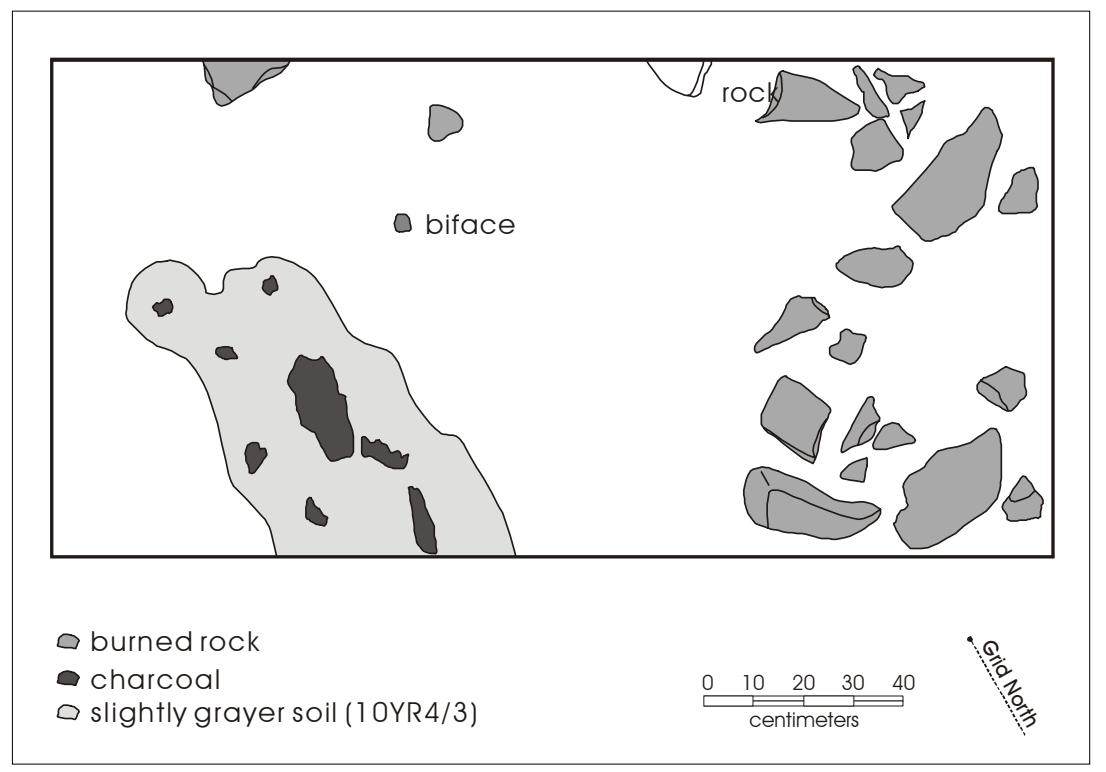

Figure 7-6. Plan view of Feature 7 in Unit 23, 41CM111. 


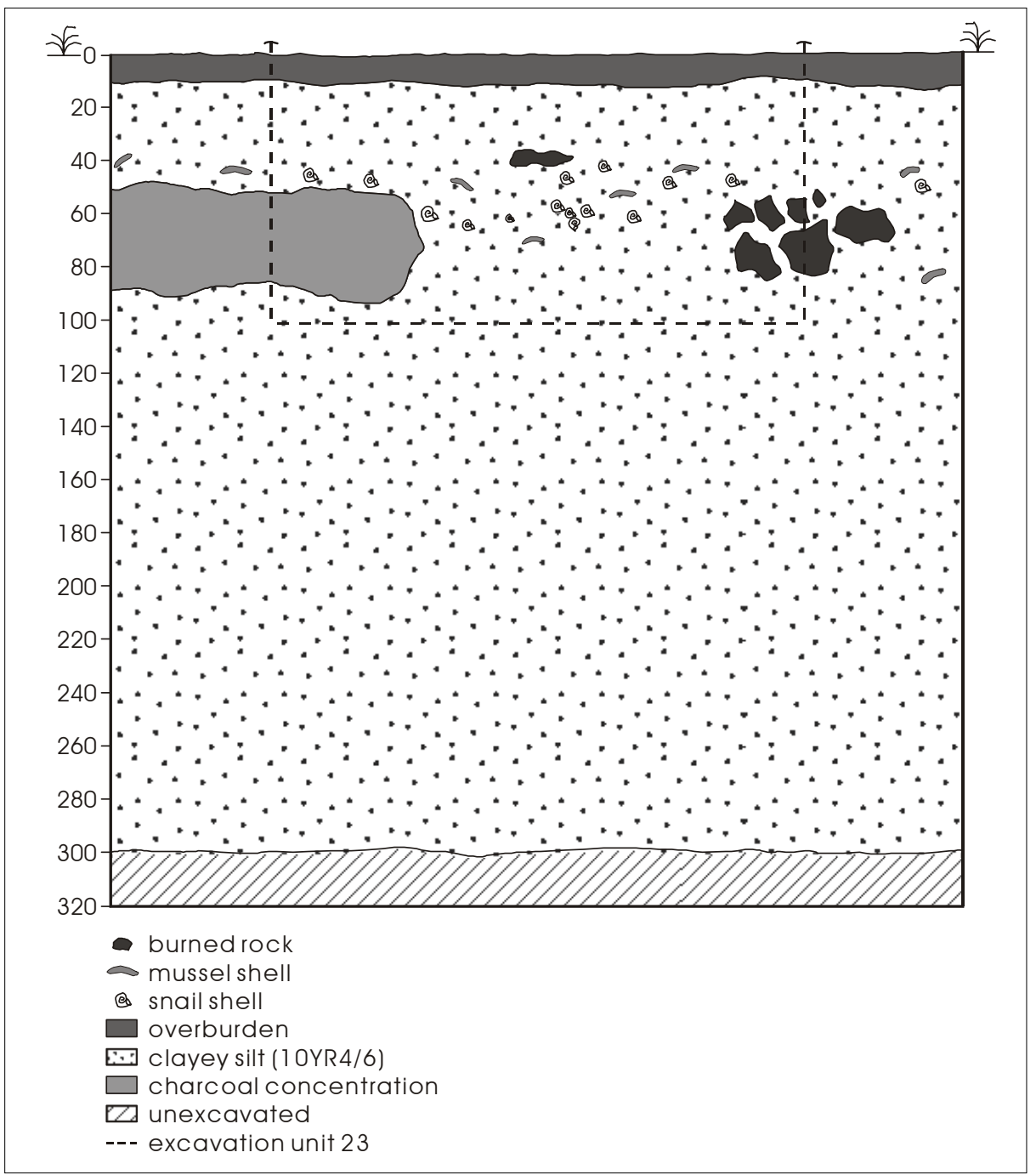

Figure 7-7. Feature 7 in north wall profile of Backhoe Trench 2, 41CM111.

representative of the southern periphery of the burned rock sheet midden, very evident north of FM 306. The small sample consists of primarily smaller, heat-fractured limestone without apparent association to intact features.

\section{Other Remains}

A variety of additional materials and special samples that may aid further interpretations in regard to the occupants of $41 \mathrm{CM} 111$ were collected during both phases of fieldwork. These materials were not part of the research design associated with the final work conducted by CAR (see Chapter 5) and are only briefly discussed here.

\section{Fire-cracked Rock}

As evidenced in the photo documentation of the 1980 excavations, abundant burned limestone rocks were encountered, primarily as constituents of the burned rock sheet midden identified in the main block excavation (see Figure 1-3). It remains unclear what type of sampling/recovery/quantification strategy was employed during these early excavations, as very few burned rock specimens $(n=366)$ were recorded in the $1980 \operatorname{lot} \log$ and/or are present in the collection. A cursory inspection of the extant burned rock assemblage indicates that much of the burned rock must have been discarded before it was returned to the lab; and the 
current collection consists primarily of heat spalls pulled from the lithic debitage.

Whereas the exact amount of burned rock cannot be tallied, the relative frequency of the material can be discerned through level photographs and the field notes. For example, in comparing the plan view sketch map of the main excavation block (see Figure 1-3) at $70 \mathrm{cmbs}$ with a plan view photograph of the main excavation block (Figure 7-8) at $80 \mathrm{cmbs}$ and other photographs of the remainder of the excavation levels, it is evident that no significant amount of burned rock occurs below $80 \mathrm{cmbs}$.
A review of the upper levels indicates no significant amount of burned rock above Level 7 (60-70 cmbs).

As mentioned previously, fire-cracked rock counts were not tabulated systematically during the 1980 excavations. For instance, only a total of 366 burned rock pieces was collected during the 1980 excavation. Unit 8, on the south side of FM 306, was the single unit with the largest quantity of burned rock recovered $(n=114,31 \%)$. On the other hand, the six units on the north side of the road yielded 197 pieces, 53 percent of all the burned rock from the site.

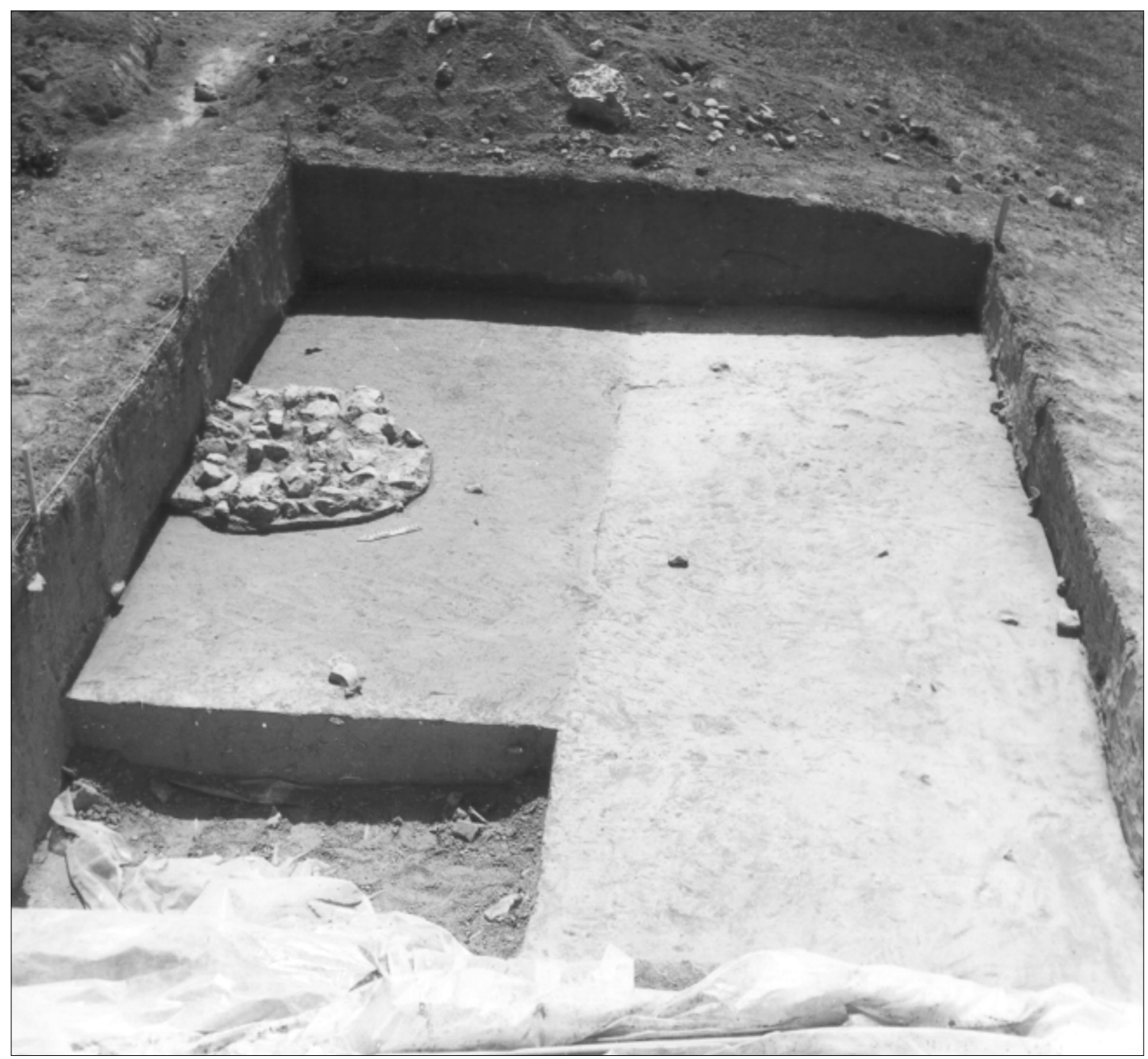

Figure 7-8. Photograph of 1980 main excavation block at the bottom of Level 8 ( $80 \mathrm{cmbs}$ ). 
The 2002 CAR excavations were placed on the south side of FM 306 in an area that was indicated to have high temporal diagnostic artifact densities per $2 \times 2-m$ unit, based on the 1980 excavations. A total of 1,166 burned rock pieces was recovered, a much larger number than that derived from the 1980 work. Unit 20 contained 55 percent of the pieces $(\mathrm{n}=641)$, followed by Unit 22 $(n=246,21 \%)$. Level $2(10-20 \mathrm{cmbs} ; n=437,36.5 \%)$ and Level 10 (90-100 cmbs; $n=155,13 \%)$ contained the highest densities. Considering that as much as $30 \mathrm{~cm}$ of the former surface may have been removed from the south side of the road, these peaks in burned rock densities may have originally been as much as $20-30$ $\mathrm{cm}$ below their measured elevations.

\section{Vertebrate Faunal Material}

The 1980 excavations produced just over 381 grams of animal bone distributed among seven excavation units $(1,2,5,6,7,9$, and 10). By weight, Level 4 (26 g) and Level $9(306 \mathrm{~g})$ contained the highest quantities of faunal remains (Table 7-2). No faunal remains were recovered from the 2002 excavations at the site.

The bones are generally highly fragmented and most display at least some surface pitting consistent with chemical weathering. The assemblage is comprised primarily of mammalian bone of indeterminate size. Of those bones that could be identified to general size category, all were ascribed to mammals of deer to sheep size. The single prehistoric bone fragment that could be identified to species level was that of a white-tailed deer (Odocoileus virginianus). Numerous carapace fragments of an armadillo (Dasypus novemcinctus) were encountered in the first $10 \mathrm{~cm}$ of the 1980 Unit 2, and are obviously not of prehistoric affiliation.

\section{Mussel Shell}

In contrast to the scant vertebrate faunal remains, relatively abundant mollusks were recovered. In total, nearly eight kilograms comprise the assemblage of mussel shell recovered during the two excavations at the site. The bulk of this category $(7,208 \mathrm{~g}, 91 \%)$ was recovered during the 1980 excavations, primarily in association with the main block excavation north of the road $(5,321 \mathrm{~g}, 74 \%)$. By weight, the mussel shell from the 1980 excavations shows three distinct peaks, one in Level 5 (40-50 cmbs; $940 \mathrm{~g}, 13 \%$ ), one in Level 9 (80-90 cmbs; $1,003 \mathrm{~g}, 14 \%$ ), and one in Level 11 (100-110 cmbs; $1,691 \mathrm{~g}, 23 \%$; Table 7-2). Interestingly, in the units excavated south of FM 306 during the 2002 season, the distribution of mussel shell steadily increases from Levels 1 through 5 and peaks in Level 6 (197 g, 29\%), decreasing in frequency thereafter (Table 7-4). This unimodal pattern is dramatically distinct from that noted in the large excavation block dug in 1980 by TxDOT. While a formal analysis of the collection has not been performed, the individual shells generally appear in good condition and should be amenable to species identification.

\section{Snail Shell}

Abundant terrestrial snail shell $(5,008 \mathrm{~g})$ was collected during both series of excavations at 41CM111, albeit in inconsistent recovery during the 1980 fieldwork (see Chapter 5, Field and Laboratory Methods). Recovery during the 1980 efforts yielded over $2.5 \mathrm{~kg}$ of shell, with roughly 30 percent $(771 \mathrm{~g}$ ) of that total occurring in Level 9 (see Table 7-2). The 2002 excavations produced nearly the same amount of snail shell $(\sim 2.5 \mathrm{~kg})$, with approximately 29 percent $(724 \mathrm{~g}$ ) of that total recovered from Level 10 (see Table 7-4). Although formal quantitative efforts in the form of a detailed analysis of the land snail samples have not been conducted, it is evident that Rabdotus dominates the overall assemblage. A cursory examination of the assemblage indicates that Rabdotus constitutes an estimated 95 percent of the collection. Other terrestrial snail species noted include Helicina and Polygyra. The representative specimens of these two species examined appear quite small and may represent a primarily juvenile constituent.

\section{Soil Samples}

Three large ( $\sim 5$ liter) soil samples were recovered during the 1980 fieldwork. The samples were recovered from the burned rock sheet midden, specifically from Feature 3 , and were stored in large polypropylene bags, labeled with an acidic sheet placed unsleeved inside the bag, and tied with cotton string. 
Aside from the soil samples extracted specifically for magnetic sediment susceptibility analysis from Unit 21 , other samples were recovered during the 2002 excavations for possible future studies. A single column of soil samples was collected from Unit 21. The samples consist of approximately two liters of matrix and were removed in correspondence with the 10-cm arbitrary levels below surface. In total, ten samples corresponding to the ten levels excavated in Unit 21 were recovered. Analyses that CAR has conducted in the past with such column samples include special studies dealing with such ecofacts as diatoms, pollen, phytoliths, macrobotanicals, and microscopic gastropods. These special studies have in the past been geared primarily toward paleoenvironmental reconstruction issues. In addition, over $200 \mathrm{~g}$ of remaining charcoal samples exist and would be available for wood identification. 



\title{
Chapter 8: $\quad$ Site Integrity and Chronology
}

\author{
Richard B. Mahoney, Harry J. Shafer, and Steve A. Tomka
}

In this chapter, we consider two principal issues, the integrity of the site's deposits and the chronological placement of the material culture recovered during the 1980 and 2002 excavations.

\section{Site Integrity}

In this section, we integrate information on stratigraphy, refits among lithic artifacts, and the results of magnetic sediment susceptibility analysis to establish the stratigraphic and associational integrity of the deposits.

\section{Stratigraphy}

From the initial auger boring placed at 41CM111, it was apparent that intact buried cultural deposits underlie the displaced burned rock, mussel shell, and lithic debris noted on surface. This disturbed material likely found its way to the surface via historic era traffic between European settlements in the surrounding Hill Country and the local hub of commerce, the community of New Braunfels. Comparison of a modern USGS topographic map with a historic U.S. Army Corps of Engineers (COE) Tactical Map (1933) shows that FM 306 or its predecessor, the Fischers Store-New Braunfels Road, has been in use since at least the early 1930s. The fact that this area provides a relatively easy crossing of Cordova Creek, given the mountainous area to the north and the floodplain to the south, may have contributed to its long-term use. The road was initially paved during the 1950s and has been maintained as a paved highway since that time. Increasing the width of the shoulders and associated grading and re-grading along FM 306 in 1980 have apparently been the only major modifications since paving.

Minor modifications that have impacted the site include primarily safety-related highway maintenance (see Chapter 5). Through these necessary maintenance activities, older sediments are impacted or truncated altogether and a resultant mix of displaced materials occurs as a disturbed layer along the current ground surface and upper portions of the intact alluvium (Figure 6-2). Apart from one historic artifact in Level 8, the remaining items $(\mathrm{n}=81 ; 99 \%)$ are from Levels $1-4 ; 74$ $(90 \%)$ of which are from Level 1 . The sparse collection of historic artifacts occurring below Level 1 was most likely introduced via the 1980 crew's ingress/egress of the units during the rain-plagued fieldwork. The sample of historic artifacts recovered from this uppermost level, Level 1, includes glass shards, bottle caps, welding rod fragments, tar/asphalt blobs, tin can fragments, and other unidentifiable metal fragments.

No true paleosol is apparent in the soil profile in the southern portion of 41CM111. As depicted in wall profiles of the excavation units and backhoe trenches (Figures 8-1 through 8-3), the natural stratigraphy was relatively consistent across the site. With the exception of the recent roadway-related construction disturbance, a single stratigraphic unit of clayey silt alluvium was generally encountered across the southern portion of the site with only minor variations noted. An occupation(s) surface defined only by a burned rock sheet midden (see following discussion) occurs within the homogenous deposits without indication of a midden stained soil. Moderate bioturbation in the form of rodent burrows was encountered within this matrix (see Figure 8-1).

Earlier fieldwork along the northern portion of the site, as expressed in the ROW, similarly failed to locate a definable paleosol in the soil profile. Figure 8-3 depicts the northern wall of the 1980 main excavation block. Three distinct sediments are present in the wall profile: the humic layer, a 24-cm-thick unit of post-occupational alluvium, and a 100-110-cm-thick unit of sediment containing the bulk of the cultural material. Again, modern and historic disturbance is relegated to the humic layer and the upper portion of the post-occupational alluvium.

Excavation of BHT-1 revealed the northern extent of the primary excavation block dug in 1980 (see Figure 5-2). The stratigraphy revealed in the northern wall profile of BHT-1 indicated an undisturbed context with a sparse northward continuation of the midden of burned rock 


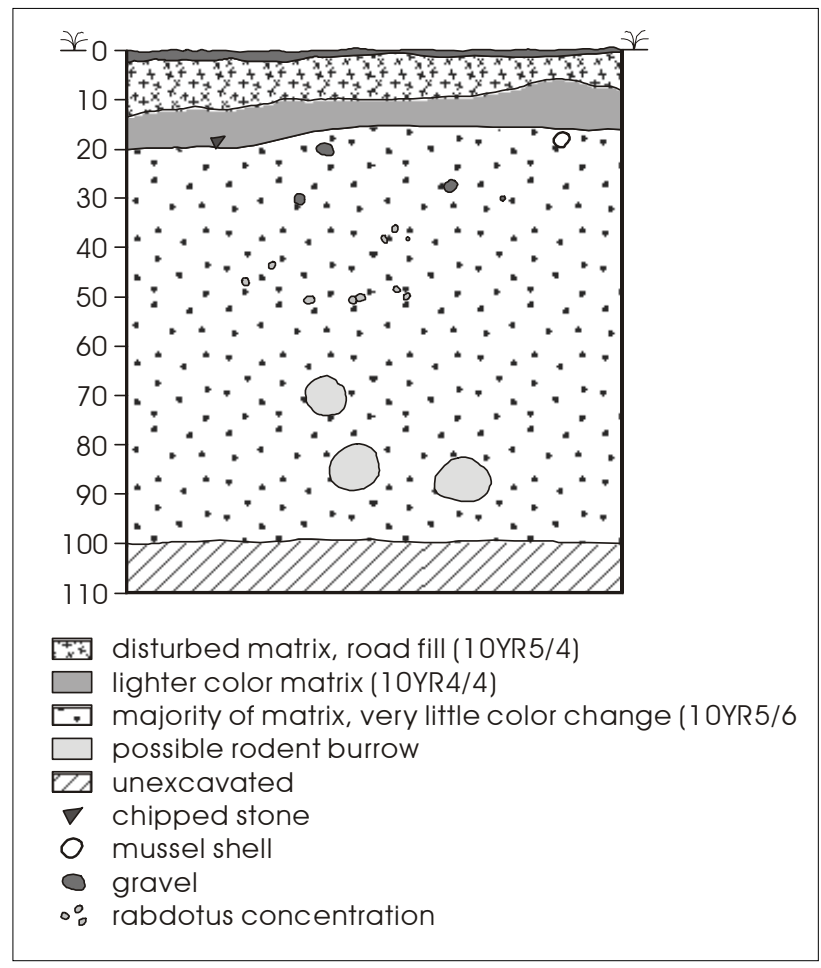

Figure 8-1. South wall profile of Unit 20, 2002 excavations at $41 C M 111$.

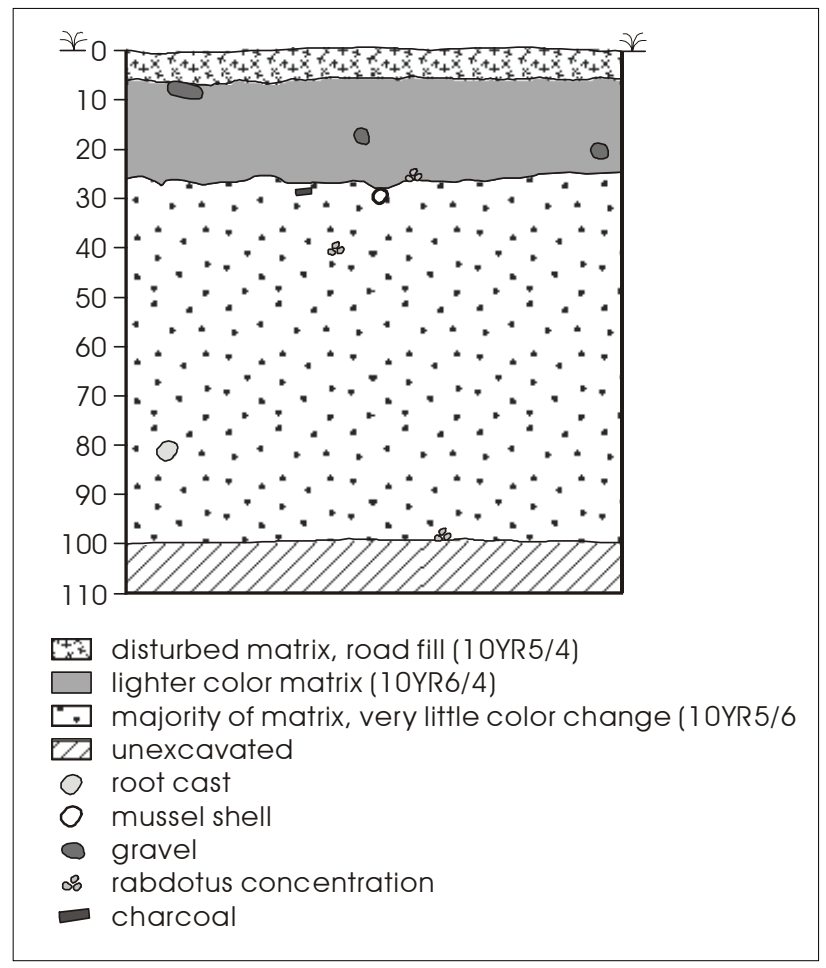

Figure 8-2. North wall profile of Unit 21, 2002 excavations at $41 C M 111$.

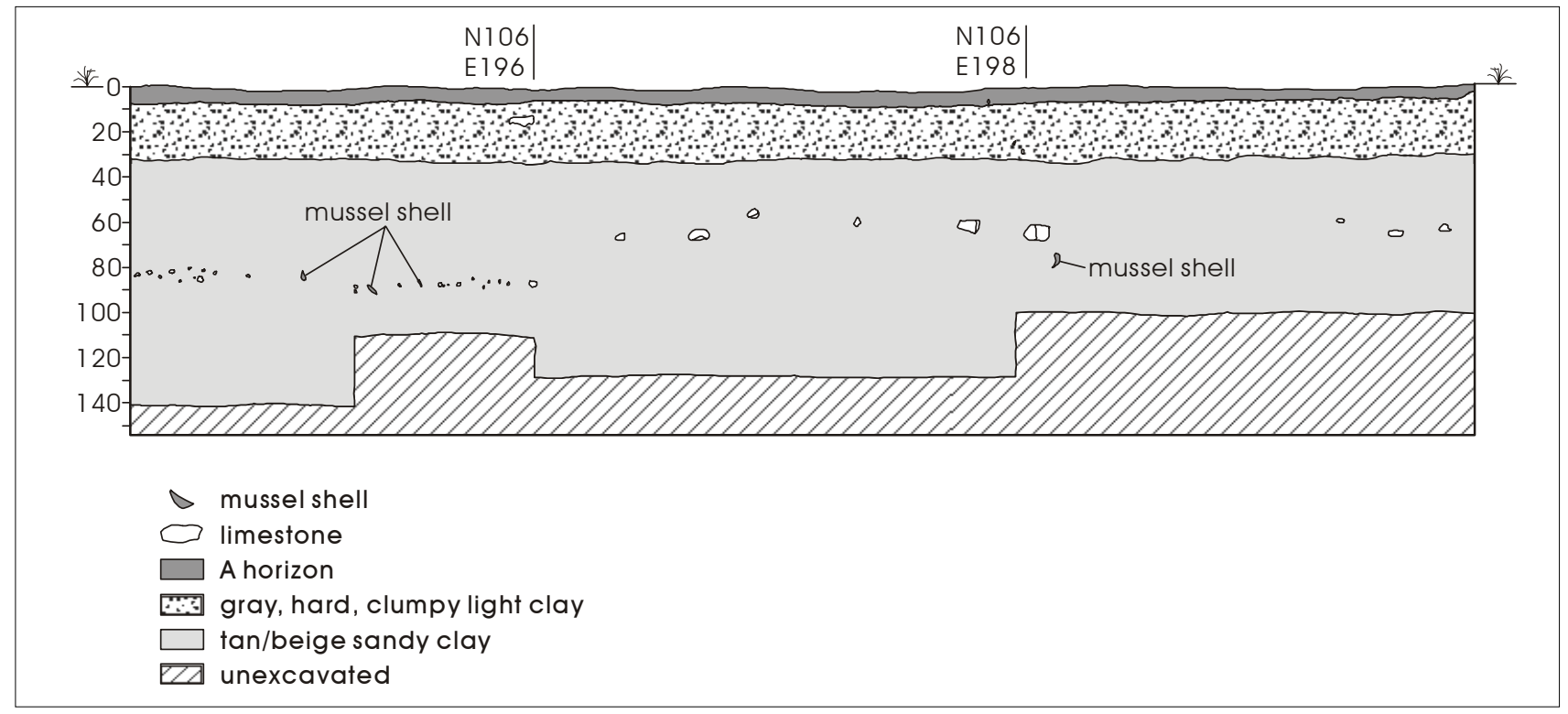

Figure 8-3. North wall profile of main excavation block north of FM 306, 1980 excavations at 41CM111. 
encountered in the original excavation block. Within this zone, a charcoal sample immediately adjacent a triangular preform fragment was recovered in apparently good context.

Correlation of the burned rock sheet midden encountered in the main excavation block north of FM 306 with the burned rock scatter encountered in the small cluster of the 1980 units south of FM 306 was not wholly possible. While it is suspected that the two burned rock zones are related, this cannot be empirically proven. A number of factors precipitate this lack of confidence. The spatial separation of the excavation units, the location of the site along a low-order tributary to such a major stream as the Guadalupe River, and the unknown impact historic use of the roadway has had on the deposits combine to instill doubt as to the unequivocal relationship of the two locales.

\section{Artifact Distribution Patterns}

We have mentioned previously that the vertical distribution of snail shells and animal bone recovered from the 1980 excavations have bimodal distributions with a corresponding upper peak in Level 4 and a lower peak in Level 9. The distributions of some of the other more common artifact categories such as unmodified debitage and mussel shells exhibit three peaks, an upper one in Level 5, a middle peak between Levels 7-9, and a lower peak in Level 11. These distribution patterns suggest that site occupation history may be characterized by at least three intensive periods of repeated site reuse or prolonged site use. Given that only five units (four 2 x 2-m and one $1 \times 1-\mathrm{m}$ ) were dug south of the road in 1980, both of these patterns are driven primarily by the larger number of units excavated north of the road. Nonetheless, these distribution patterns clearly suggest the presence of two distinct zones of archeological materials.

Somewhat similar vertical distributional patterns may be evident from the materials recovered during the 2002 excavations that occurred along the southern portion of the road. While snail shells and burned rock distributions have a bimodal pattern, mussel shells and unmodified debitage have single peaks but separated by some $30 \mathrm{~cm}$ (Table 7-4). South of the road, debitage peaks in Level 3 and steadily decreases thereafter. The weight of mussel shell peaks only in Level 6, while the weight of snail shell peaks in Levels 5 and 10. Interestingly, burned rock counts peak in Level 2 and Level 10, with the upper peak being only $10 \mathrm{~cm}$ higher than the peak in unmodified debitage.

The contrast in artifact distribution between the northern and southern excavation units suggests that if there are two distinct identifiable depositional units on site, they are manifested quite differently across the site. This should not be a surprising possibility since it would be much more unlikely that two or more re-occupations of a landform would result in exactly the same organization of space during the occupations, particularly since site furniture and facilities on hunter-gatherer sites are very minimal and rarely serve to anchor activities in space.

\section{Lithic Artifact Refits}

One way to gauge the vertical movement of materials through a profile is through the distribution of artifact refits. Three examples of refits were discovered in the analysis. One is an Early Triangular preform (8G-001, 8I-001) broken into two pieces during manufacture and refitted in the lab (Figure 7-3c). These two fragments were found $20 \mathrm{~cm}$ apart in the unit. Opposite sides of the fragments are patinated.

Two examples of flake refits were found during the inspection of the debitage from Units 3 and 8. The first consists of two biface thinning flakes removed in sequence (Figure 8-4). These were discovered in Unit 8, Level 7. The second is a series of three corticate flakes removed from a stream-rolled chert cobble (Figure 8-5). Four additional flakes were found that belong to this same core, but could not be refitted. All but one of the flakes came from Unit 3, Level 9; one, however, came from Level 7, $10 \mathrm{~cm}$ above the concentration.

These refit examples provide important information on site formation processes (Hofman 1992; Stackelbeck 2000). Relatively intact chipping areas suggest in situ production, and that the debitage was not significantly moved horizontally from the place where it was deposited. This interpretation holds for all examples. The vertical displacement of the one piece belonging to the second refit example suggests bioturbation of the deposits. Based on the refitted examples, the tentative 


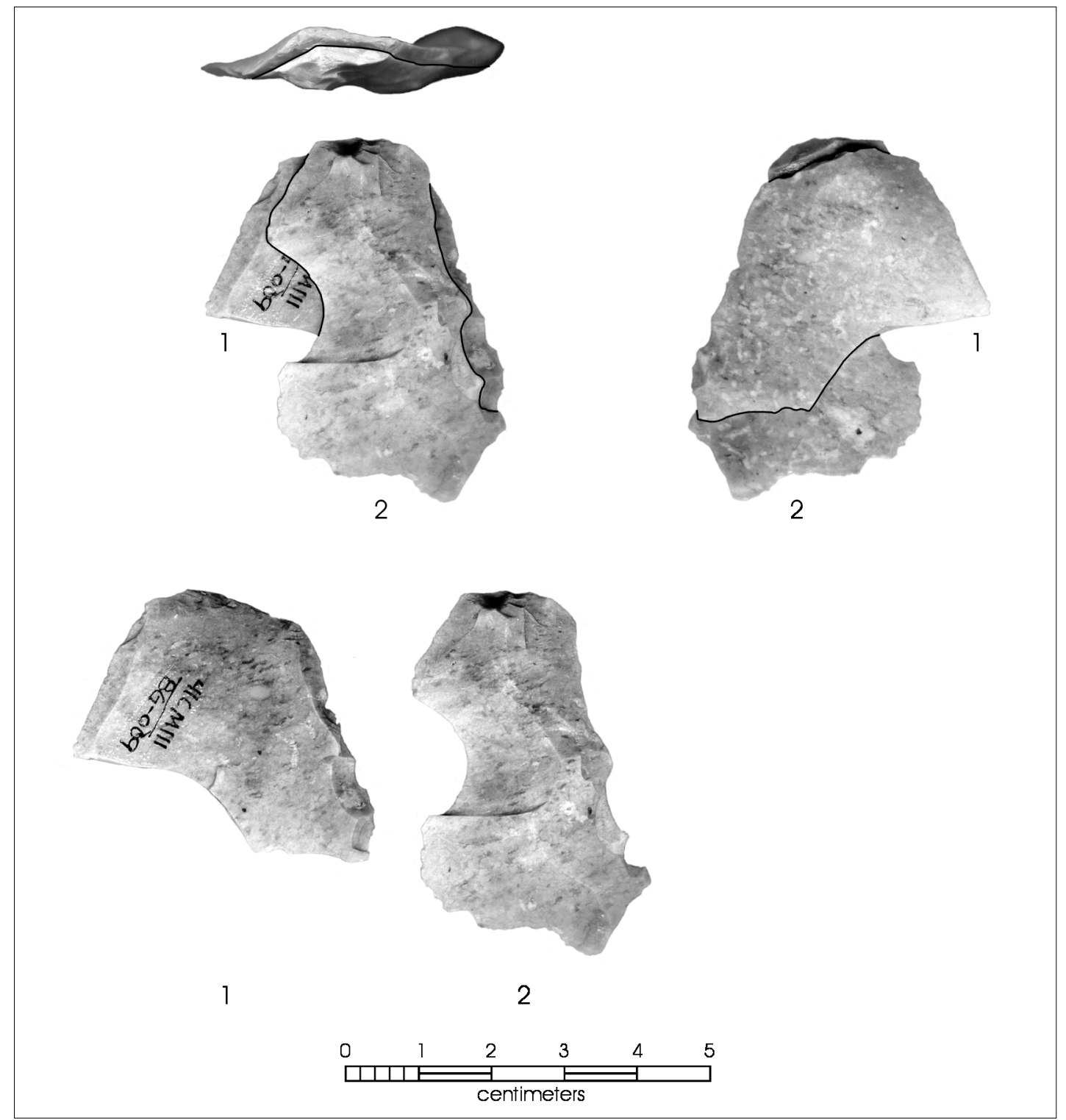

Figure 8-4. Views of two biface thinning flakes removed in sequence and refitted.

interpretation of site formation processes is that the cultural deposit was blanketed during a geological interval shortly after the deposit accumulated. The time interval, however, could have been from a few months to centuries. Furthermore, the refits suggest the site's surface was not adversely affected by erosion or deflation, but rather probably was stable for some period of time. Refit data and distribution of burned chert also indicate some evidence that subsequent to deposition, the cultural deposits were disturbed by bioturbation. 


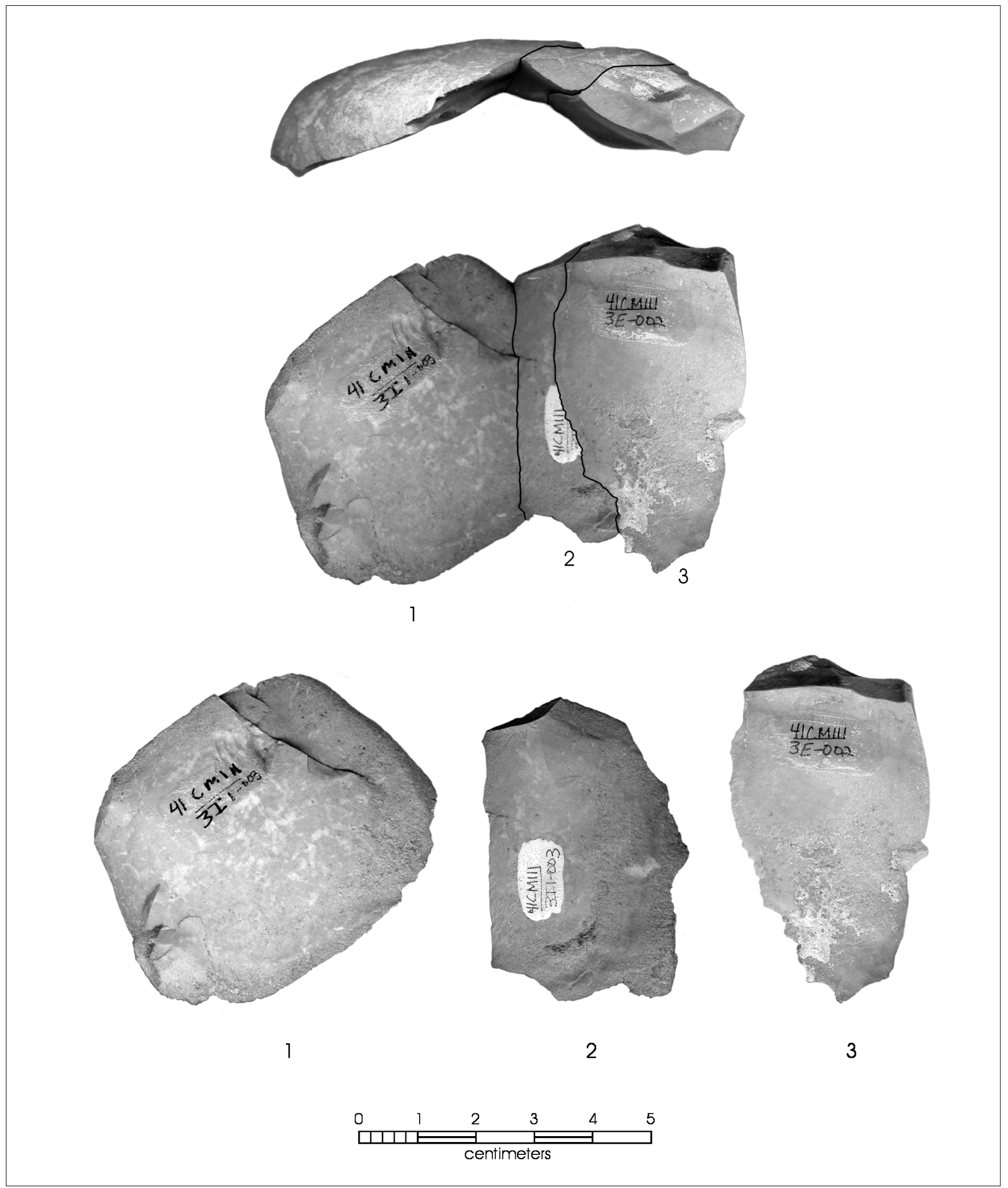

Figure 8-5. Views of three corticate flakes from a stream-rolled cobble removed in sequence and refitted. 


\section{Magnetic Sediment Susceptibility Results}

A total of 10 soil samples from Unit 21 was analyzed for magnetic soil susceptibility signatures. Appendix C presents these raw data. As discussed in Appendix C, the magnetic susceptibility of sediment provides a measure of how easily that sample can be magnetized. Several processes can result in an increase in the susceptibility value within a given sediment sample. Of primary concern in the present context is the observation that sediments with high organic content tend to have elevated magnetic susceptibility values, probably as a function of the production of maghemite, an iron oxide, during organic decay (Reynolds and King 1995). Pedogenic processes, such as soil formation and weathering, as well as cultural processes, such as the production of ash and the concentration of other organic material on a living surface, will produce high magnetic susceptibility (MS) values.
Figure 8-6 presents the MS values for Unit 21 by depth. Overall, the samples ranged from a low of 26.14 to a high of 31.97. The MS values are lowest near the surface and, in general, tend to increase with increasing depth. A closer examination of the figure suggests that two peaks may be present, with the first occurring between 30 and $40 \mathrm{cmbs}$ and a more distinct peak occurring between 80 and $90 \mathrm{cmbs}$. This pattern may be suggestive of the presence of two buried surfaces that may have accumulated higher organic content over time.

With approximately $20 \mathrm{~cm}$ of matrix removed via roadway-related grading during the 1990s, the peaks exhibited in Unit 21 would align well with artifact densities contained within the 1980 main excavation block. Specifically, the first peak in MS values between 30 and $40 \mathrm{cmbs}$ would correspond to the slight increase in artifacts exhibited in Level 5 of the main block north of FM 306. Correspondingly, the deeper peak in MS

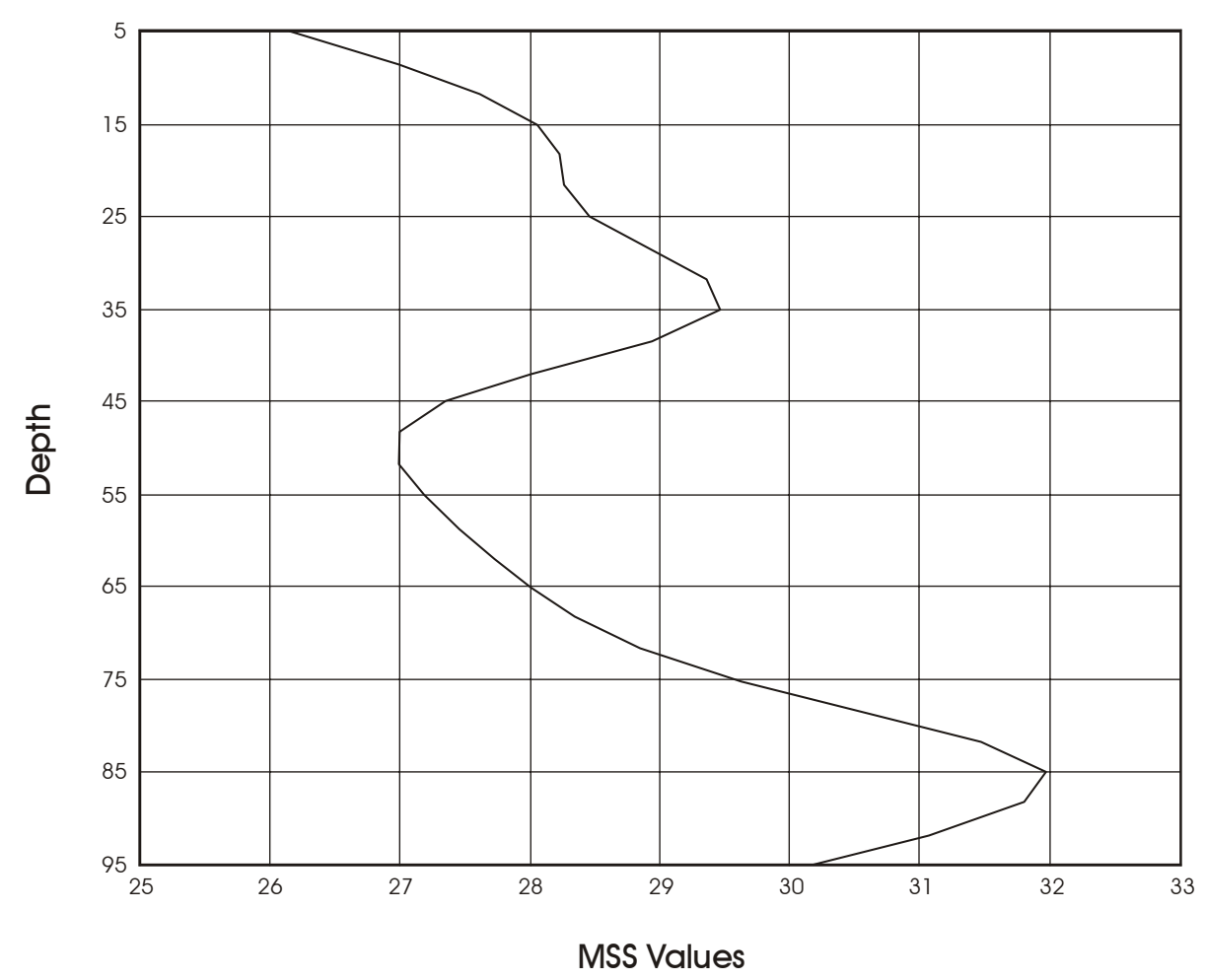

Figure 8-6. Distribution of magnetic sediment susceptibility values by depth below surface (cmbs) in Unit 21. 
values between 80 and $90 \mathrm{cmbs}$ may correspond with the increase in cultural material occurring in Level 11, below the burned rock sheet midden in the main excavation block.

One of the interesting aspects of the MS values is that the peaks in values correspond well with the peaks in artifact densities in TxDOT's block excavations on the north side of FM 306, yet Unit 21 is located on the south side of the road. This correspondence between the two sides of the road seems to support the observation made in Chapter 7 that the living surface that was so strongly manifested on the north side of the road also extends south of FM 306. However, the fact that mussel shells and unmodified debitage seem to have unimodal distributions on the south side of the road (see Table 7-4; CAR excavations), compared to the bimodal pattern noted in the 1980 TxDOT materials, indicates that there may have been significant variability in the use of space during the two principal occupations of the site.

\section{Site Chronology}

In this section, we discuss the results of the radiocarbon assays and the distribution of temporal diagnostic artifacts to establish the age of the deposits and relate this information to the formation processes responsible for these deposits.

\section{Radiocarbon Results}

A total of six charcoal samples and one humate sample, chosen in consultation with TxDOT, was submitted to Beta Analytic, Inc., of Miami, Florida for radiometric assays. All samples were corrected for differing fractionation, and all samples were calibrated using version 3.5 of OxCal (Ramsey 2000). The sampling strategy employed focused on the rock stratum encountered in the main excavation block, the probable continuance of that occupation surface south of FM 306, and the single feature encountered during the 2002 field efforts. Aside from the humate sample, the remainder of the samples was recovered during the manual excavations in apparently undisturbed stratigraphic context. The single humate sample was recovered from BHT-5 at 165-170 cmbs. A combination of three samples from the TxDOT investigations and four samples from the CAR investigations were chosen. Table 8-1 presents the corrected radiocarbon ages of the seven samples, along with their Beta Analytic sample numbers, provenience information, and diagnostic and/or feature association. Additional information on these samples can be found in Appendix B.

The burned rock stratum encountered in the main excavation block north of FM 306 appeared to be the densest portion of the site as expressed within the ROW. With at least one intact feature (Feature 3) visible and only slight relief across the surface of the burned rock sheet midden, the deposits were judged to have good integrity and amenable to confident radiometric dating. Two samples were chosen from the main excavation block (Beta Sample Nos. 166715 and 166716). The samples were chosen to more or less "bracket" the sheet midden (see Mahoney and Tomka 2001:31) between 70-90 cmbs and also to investigate two very different peaks in artifact density expressed in the recovered assemblage. Sample No. 1 (Beta Sample No. 166715) was recovered near the uppermost aspect of the midden and

Table 8-1. Summary of radiocarbon samples, proveniences, associated artifacts, and dates from 41CM111

\begin{tabular}{|c|c|c|c|c|c|c|c|c|c|c|c|}
\hline 冚 & 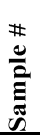 & \#تّ & $\begin{array}{l}\text { \# } \\
\stackrel{0}{\rho}\end{array}$ & 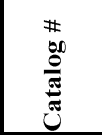 & 急 & 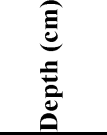 & 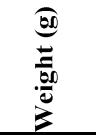 & Associated Diagnostics & $\begin{array}{c}\text { Conventional } \\
\text { Radiocarbon } \\
\text { Age }\end{array}$ & $\begin{array}{c}\text { Calibrated } \\
\text { BP Range } \\
\text { at 1-Sigma }\end{array}$ & $\begin{array}{l}\text { Calibrated } \\
\text { BP Range } \\
\text { at 2-Sigma }\end{array}$ \\
\hline TxDOT & 1 & 166715 & $02 \mathrm{H} 1$ & $02 \mathrm{H} 1-3$ & 2 & $70-75$ & 071.30 & Early Triangular (1) & $4820+/-60$ & $5600-5480$ & $5650-5340$ \\
\hline TxDOT & 2 & 166716 & $04 \mathrm{I} 2$ & $04 \mathrm{I} 2-2$ & 4 & $85-90$ & 048.18 & Early Triangular (2); Nolan (1) & $4990+/-40$ & $5740-5660$ & $5880-5620$ \\
\hline TxDOT & 3 & 166717 & $08 \mathrm{H}$ & $8 \mathrm{H}-3$ & 8 & $70-80$ & 088.46 & Early Triangular (4); Bell (1) & $4770+/-60$ & $5590-5460$ & $5610-5320$ \\
\hline CAR & 4 & 166718 & $21 \mathrm{C} 3$ & $21 \mathrm{C} 3$ & 21 & $@, 28$ & 004.40 & Early Triangular (1) & $4780+/-40$ & $5590-5470$ & $5600-5340$ \\
\hline CAR & 5 & 166719 & $21 \mathrm{D} 2$ & $21 \mathrm{D} 2$ & 21 & $@, 33$ & 004.70 & Early Triangular (1) & $4840+/-40$ & $5600-5580$ & $5640-5480$ \\
\hline CAR & 6 & 166720 & BHT2 & BHT2-1 & BHT2 & $@, 56$ & 147.20 & Burned Rock Feature 7 & $4340+/-70$ & $4970-4840$ & $5220-4820$ \\
\hline CAR & 7 & 166721 & BHT5 & BHT5 & BHT 5 & $165-170$ & 293.40 & (humate) & $2930+/-40$ & $3204-2995$ & $3237-2950$ \\
\hline
\end{tabular}


within the densest concentration of burned rock (based on field documentation), while Sample No. 2 (Beta Sample No. 166716) was recovered near the lower portion of the midden and within the densest concentration of debitage. If the assumption is made that the radiocarbon date accurately reflects the date of the deposits with which it is associated, then the strategy of bracketing a stratum should provide a beginning and ending date for that stratum.

The calibrated 2-sigma date range indicates that the upper portion of the deposits dates to around 5650-5340 BP. The lower portion of the deposits dates to around 5880 $5620 \mathrm{BP}$. The dates suggest that the samples are from undisturbed depositional contexts.

Table 8-2 presents additional information on radiocarbon dates and sediment accumulation rate for the burned rock sheet midden. Here, we have used the interval estimate provided by the calibration program to calculate the time between the two dates. The procedure provides a probability estimate of the number of years represented between the two dates (Ramsey 2000). Assuming that the radiocarbon dates reflect the time of sediment accumulation, and using the 2-sigma range as an example, the upper and lower dates for the midden suggest that there is a 95.4 percent probability that sediments may have accumulated over a period of between 10 and 400 years.

The final two columns of Table 8-2 provide information on the thickness of the deposit between the dates and the accumulation rate. We use the midpoint of the 2 -sigma range as a time estimate, and the elevation difference, in centimeters, between dates as a thickness estimate. While a number of assumptions are involved, the accumulation rate provides a gross estimate of the rate of deposition and, by extension, the probability that the midden potentially represents a palimpsest. That is, high accumulation rates are less likely to be overprinted by multiple occupations, and thereby complicate the interpretive potential of the deposits.
The radiocarbon dates suggest that the sediments accumulated over a relatively brief period of time. While a number of interpretations of these data are possible, it is likely that the sediments accumulated in no more than 400 years, and it could be the case that the accumulation was much faster.

In an attempt to correlate the cluster of excavation units located south of FM 306 with the apparent continuation of the midden north of the road, charcoal samples were sought from the earlier fieldwork from Units 7 (N78/ E192), 8 (N80/E200), and 9 (N80/E202) or the later fieldwork from Units 20, 21, and 22.

The 1980 Unit 8 (N80/E200) did produce a single charcoal sample (catalog no. $8 \mathrm{H}-003$ ) that appeared in good stratigraphic order and was collected from Level 8 (70-80 cmbs) of the $2 \times 2-\mathrm{m}$ unit and roughly correlated to the upper portion of the deposit dated on the north side of FM 306. This radiocarbon assay returned a calibrated radiocarbon date range of 5610-5320 BP at 2-sigma (Beta Sample No. 166717). The date correlates well with the date of the upper portion of the same depositional zone located north of FM 306 (see sample 166715 from Unit 2; 5650-5340 BP 2-sigma range; $70-75 \mathrm{cmbs})$.

Lacking similar bracketing charcoal samples for the lower portion of the deposits in Unit 8, two pointprovenienced samples recovered from Unit 21 and representing the upper and lower aspects of the burned rock/debitage peaks were processed next. This unit was located less than two meters grid south of the contiguous 1980 units 8 (N80/E200) and 9 (N80/E202) and was judged to represent the same deposits as manifested in Unit 8. Each charcoal sample was encountered in situ and in close association with Early Triangular dart points. While it would not be warranted to assume that a single charcoal sample recovered in proximity to a single dart point would date that particular artifact, the recovery of two samples recovered in close proximity to two dart

Table 8-2. Sediment accumulation rates at 1980 TxDOT excavation block on the north side of FM 306

\begin{tabular}{|c|c|c|c|c|c|}
\hline $\begin{array}{c}{ }^{14} \mathbf{C} \text { Location } \\
\mathbf{1}\end{array}$ & $\begin{array}{c}{ }^{14} \mathbf{C} \text { Location } \\
\mathbf{2}\end{array}$ & $\begin{array}{c}\text { 2-sigma } \\
\text { interval range }\end{array}$ & $\begin{array}{c}\text { Midpoint of } \\
\text { 2-sigma interval }\end{array}$ & $\begin{array}{c}\text { cm separating } \\
\text { dates }\end{array}$ & $\begin{array}{c}\text { Accumulation rate } \\
\text { (cm/100 years) }\end{array}$ \\
\hline $70-75 \mathrm{cmbs}$ & $85-90 \mathrm{cmbs}$ & $10-400$ & 205 & 15 & 7.32 \\
\hline
\end{tabular}


points within a $5-6 \mathrm{~cm}$ level in a single $1-\mathrm{m}^{2}$ unit deserves a second look.

Specifically, the two samples (Beta Sample nos. 166718 and 166719) occur at 28 and $33 \mathrm{cmbs}$ (dating at 5600$5340 \mathrm{BP}$ and 5640-5480 BP, respectively), and the associated Early Triangular dart points (catalog nos. 21C2-001 and 21D3-001) occur at 27 and $33 \mathrm{cmbs}$. Clearly, the association of these artifacts suggests that the deposits encountered in Unit 21 at this level are relatively securely dated. This calibrated date range was calculated with the CALIB program (Stuvier and Reimer 1993), first averaging the two conventional dates (4780 $\pm 40 \mathrm{BP}$ and $4840 \pm 40 \mathrm{BP}$ ) and later running a calibration on the resultant average $(4810.2 \pm 29.4 \mathrm{BP})$. Prior to averaging the two dates, a t-test was performed to determine whether the dates are statistically the same or significantly different. The dates were determined to be statistically the same, thereby producing a valid average date for calibration. The average of the two dates was then calibrated with the resultant BP range at 1-sigma at 5592-5488 and the BP range at 2-sigma at $5600-5474$.

The dates from Beta Sample numbers 166718 and 166719 are virtually identical to the date from Beta Sample number 166717 from Unit 8, although the former pair of dates (at 28 and $33 \mathrm{cmbs}$ respectively) are some $45 \mathrm{~cm}$ higher in the profile than the sample from Unit 8 (70-80 cmbs). The differences in depth below surface between the samples may mean that some $45 \mathrm{~cm}$ of deposits have been bladed off the surface where Unit 21 is now located. Another possibility is that there had been a natural downward slope to the landform running southward and as a result materials would have been buried more shallowly as one moved towards Cordova Creek compared to the northern portion of the site. Finally, it is also possible that some fill may have been added to the original surface prior to the $1950 \mathrm{~s}$ road construction resulting in the artificial burial of archeological deposits in the immediate vicinity of the roadway. Nonetheless, given the similarity in radiocarbon dates, it is safe to assume that the sample from Unit 8 is consistent with the two samples recovered from Unit 21, and all three samples date the same depositional unit. Moreover, the sample from Unit 8 was encountered in the same excavation level as a Bell dart point (catalog no. 8H-001) and a triangular preform (catalog no. 8H-002). The level immediately above contained one Early Triangular dart point (catalog no. 8G-001) and two triangular preforms (catalog nos. 8G-002 and 8G-003). The level immediately below contained a single triangular preform (catalog no. 8I-001).

These limited analyses on materials recovered from the north and south sides of FM 306 have provided a solid range of dates for the component containing the burned rock sheet midden and have convincingly demonstrated that the midden did extend as far south as the cluster of units situated south of the road. Similarly, it is apparent that perhaps as much as $40-45 \mathrm{~cm}$ of sediments may have been removed from south of FM 306 during the 22 years separating the two seasons of fieldwork.

The lone incongruity encountered in the suite of radiocarbon dates comes from the single hearth feature (Feature 7) encountered during the 2002 investigations. Recovered from an abundant quantity of apparently in situ charred wood, the sample (catalog no. BHT2-1) returned a calibrated date of 5220-4820 BP at 2-sigma (Beta Sample No. 166720; Table 8-1), roughly 500 years younger than the remainder of the site. Notably, the feature was encountered in Level 6 of Unit 23; a full 30 $\mathrm{cm}$ below where the group of projectile points, bifaces, and charcoal samples were recovered just a few meters away. If we assume that the former ground surface was more or less level across the site during prehistoric occupation, and taking into consideration the amount of material removed during the latter part of the twentieth century, the feature would necessarily have to have been located at the bottom of a pit over $30 \mathrm{~cm}$ below the earlier component and roughly one meter below the ground surface extant during the earlier fieldwork.

In summary, the radiometric dating of the deposits at 41CM111 indicates that the site was initially occupied during the onset of the Middle Archaic, at about 5600 BP. In particular, it has been shown that Early Triangular, Bell, and Nolan dart points were all recovered from the same dated provenience at roughly $5600-5500 \mathrm{BP}$. The single hearth feature encountered during the 2002 investigations proved a curious anomaly, occurring a full $30 \mathrm{~cm}$ below the other cultural material yet dating half a millennium older than those same deposits. 


\section{Distribution of Temporally Diagnostic Projectile Points}

Site chronology is assessed on the basis of the internal distribution of diagnostic point types shown to have temporal validity in the regional chronology (Prewitt 1981; Sorrow et al. 1967; Turner and Hester 1999: 50-63). The chronological information provided by the diagnostic projectile points is compared to the radiocarbon dates to assess more precisely when the site was occupied.

Two important issues need to be resolved before the point/radiocarbon data can be compared. The first question is: are the point types represented in the assemblage contemporaneous? If not, what are the overall date ranges represented in the projectile point assemblage and how do these date ranges compare with the radiocarbon dates obtained from the site? Before this question is addressed, however, a brief statement about systematics is in order.

The 41CM111 assemblage spans the early to late Middle Archaic following the chronological scheme used by Central Texas archeologists (Collins 1995:Table 2; Collins, et al. 1998:Figure 4-1; Decker et al. 2000:Figure 1; Johnson and Goode 1994:Figure 2). The collection can be labeled Middle Archaic as defined by Collins et al. (1998:239-244) at the Wilson-Leonard site or Early Archaic III and Middle Archaic as defined by Decker et al. (2000:226) at the Woodrow Heard site based on the point types present (Nolan, Bell, and Early Triangular).

The projectile point assemblage at 41CM111 contains an admixture of Middle Archaic types Nolan, Bell, and Early Triangular as well as Lower Pecos types Pandale and Langtry. A single Martindale point was recovered from the surface. Comal County is on the periphery of the distribution for Pandale and Langtry, but their presence is not surprising and is helpful in assessing the overall date ranges for the various occupations. Pandale has been reported from the Panther Springs Creek site in San Antonio (Black and McGraw 1985:120) and from the Woodrow Heard site (Decker et al. 2000:224, Figure 150f). The specimen tentatively classed as Langtry also falls within the eastern variants of that type as reported at the Panther Springs Creek site and elsewhere (e.g., Decker et al. 2000:225, Figure 151e-g).
The single Langtry specimen comes from Level 3 of Unit 3 (N106/E200). In conjunction with the upper peak in a number of artifact classes in the excavation block located north of FM 306, and in isolated units south of the road, it may indicate the presence of an upper late Middle Archaic component at the site. We do not have dates for this component and it may be very weak evidence to assume that the single Langtry point necessarily dates the age of this depositional unit. Nonetheless, it is clear that an upper component, tentatively dated to the late Middle Archaic period, is present on site.

The identification of additional isolable components is much more tenuous at the site. One has to rely on the range of typed projectile points to identify elements of other components, although these additional components are not clearly isolable, as indicated below.

In general, Andice/Bell points are present in Levels 8 and 10 (Table 7-5), although the Bell preform is from Level 5. Of the seven Early Triangular points, two are from Level 11, one is from Level 7, and two others are from Levels 3 and 4 . The remaining two come from surface and an undocumented depth between 0-2 feet below surface. The 16 Early Triangular preforms actually consist of 17 broken fragments and complete specimens since one of the complete specimens consists of two refit fragments from different proveniences. One of the fragments is rather poorly provenienced having been recovered in Backhoe Trench 1. The remaining 16 wellprovenienced Early Triangular preforms and fragments have a bimodal distributional pattern. Eight of the specimens are distributed between Levels 5-7 (three in Level 5, two in Level 6, and three in Level 7). Level 8 yielded only one Early Triangular preform, while Levels 9-11 have seven specimens (four in Level 9, one in Level 10, and two in Level 11). This bimodal distribution is even more evident when both finished and preform versions of Early Triangular points are considered together. Nolan points are present in Levels 9 and 11, while Pandale and Nolan/Pandale specimens occur throughout Levels 9, 10,11, and 13, as well as in higher levels (Levels 3 and 6, with one each). In addition, of the two Nolan preforms, one is from surface and the other is from Level 5. Based on face value, the cooccurrence of all three main projectile point forms (Nolan/Pandale, Andice/Bell, Early Triangular) within the four deepest levels $(8-11)$ and the presence of an 
upper peak in Early Triangular preforms in Levels 5-7 suggests one of two things: first, that the point types are contemporaneous, or second, the deposits are mixed and probably accumulated on a relatively stable surface that may have been exposed for perhaps as long as 400 years prior to burial by more recent alluvium. The first possibility is addressed first.

The lack of a clear temporal separation between the Nolan/Pandale component and the Andice/Bell-Early Triangular component, the two proposed components of this Middle Archaic assemblage, might seem to indicate contemporaneity. While these components are frequently found mixed, there are enough convincing data to suggest otherwise. Using conventional radiocarbon dates, Nolan points date approximately 4000$4500 \mathrm{BP}$ in the Central Texas chronology, and Pandale points date $4800 \mathrm{BP} \pm 500$ years in the lower Pecos chronology (Dibble 1967:Figure 23; Turpin 1982:Table 2). Early Triangular (or Taylor of Collins et al. 1998) are dated to about 4500-4800 BP, while Bell-AndiceCalf Creek are dated ca. 4800-5800 BP, and Martindale, Uvalde-Gower date to about 5800-7000 BP (Collins et al. 1998:Figure 4-1). We have already mentioned that Prewitt (1981:78) dates Early Triangular dart points to 5000-4600 BP and Nolan dart points to around 46004000 BP (Prewitt 1981:79 and Figure 4). A single date for an Early Triangular component at the Panther Springs Creek site (41BX228) suggests that the point type dates to around $5330 \pm 170 \mathrm{BP}$. An additional date from the Nolan component at the same site dates to roughly $4870 \pm 130 \mathrm{BP}$. Turner and Hester (1999:108), however, propose a date range of 5950-4450 BP for Nolan and a range of 5700-5600 BP for Early Triangular. If the estimated date ranges of the various point types in the assemblage are taken into consideration, the potential date range for the site occupation could extend between 7000 and 4000 BP. Excluding the extremes (Langtry and Martindale), the potential date range is narrowed to ca. 4000-5800 BP. As a reminder, even the broadest interpretation of the radiocarbon samples from $41 \mathrm{CM} 111$, including the seemingly incongruous date from Feature 7, only suggests a date range from 4820-5880 BP. Therefore, at its most extreme, it is possible that the deposits found between Levels 6 and 11 accumulated sometime during a period of 1,000 years, rather than the 400 -year estimate mentioned earlier. It is interesting to note that this date range incorporates the range of the Nolan and Early Triangular components at 41BX228.

All of the Central Texas point types cited here are often recovered mixed to varying degrees. This mixing of types presents a confusing picture if one is attempting to seriate components. The mixing, however, is likely revealing quite a different phenomenon: that of a pattern of repeated uses of a stable or slowly aggrading surface. A brief review of sites with Early and Middle Archaic components will demonstrate this point.

Periods of climatic stability occurred across the southcentral part of the continent around 9,000, 7,000, 5,5004,500, and 1,500-1,000 years ago (Nordt 1992, 1993; Ricklis and Collins 1994:68). The period 5,500 to 4,500 years ago occurred during Middle Archaic times and is applicable to the interpretations at 41CM111.

The assumption that there are three overall components (the upper late Middle Archaic component and two lower mixed early Middle Archaic components) represented in the 41CM111 assemblage is based on the stratigraphic separation of Nolan and Bell-Early Triangular points at Landslide (Sorrow et al. 1967) and John Ischy sites (Sorrow 1969). At other sites, however, these Middle Archaic components occur in variously mixed contexts, as they do at 41CM111. Examples include WilsonLeonard, Woodrow Heard, Barton, Shep, and Wounded Eye. A brief review of the Middle Archaic components at these sites will illustrate the point.

The admixture of point types from the Middle Archaic component at Wilson-Leonard (Collins et al. 1998:Table 9-14) include Bell/Andice, Baker, Bandy, Bulverde-like, Gower, Gower/Uvalde, Hoxie, Martindale, Jetta, Nolan, Travis, Travis-like, Gary, Marcos, Early Triangular, and several untyped specimens. Nolan $(n=21)$, Bell/Andice $(n=6)$, Travis $(n=5)$, and Early Triangular $(n=4)$ types had the highest numbers of specimens.

At the Woodrow Heard site, Early Triangular projectile points were common $(\mathrm{n}=34)$. Decker et al. (2000) divide the chronological sequence into eight intervals (1-8; Decker et al. 2000:Table 17). Decker et al. (2000:135) correctly warn us that these intervals are defined as gross age assessments and are not based on stratigraphic integrity, and therefore should not be used as stratigraphic 
intervals. Interval 1 was Early Archaic I with Angostura being the diagnostic point type. Interval 2 was unrepresentative and was interpreted as an unconformity. Interval 3, Early Archaic III dating from 6500-4500 BP, had point diagnostics Baker, Bell, Early Triangular, Martindale, and Uvalde. Site interval 4 contained the Middle Archaic assemblage with point types Nolan, La Jita, Pandale, and Travis. Unfortunately, the Woodrow Heard site lacked stratigraphic separation of the temporal components present, and while the Early Triangular assemblage was well represented, the obvious stratigraphic mixing of the deposits prevents meaningful comparisons with 41CM111.

The Early Archaic assemblage at the Barton site (41HY202) included Bell/Andice ( $\mathrm{n}=11)$, Uvalde $(\mathrm{n}=4)$, Early Triangular $(n=3)$, Wilson $(n=1)$, Gower $(n=1)$, Angostura $(n=1)$, and untyped $(n=2)$. Vertical separation of the types was minimal at the very best, apparently due to the fact that the occupation surface was stable during the period of Early Archaic use (Ricklis and Collins 1994).

The Sleeper site (41BC65) yielded an almost exclusively Early Archaic assemblage with a minor admixture of a Middle Archaic component. The assemblage was dominated by what Johnson (1991:111) refers to as "early split stem" series that includes types Gower, Gower-like, Uvalde, Baker, and Jetta. In addition to these types or their variants, Bell/Andice and Early Triangular were also represented in the inventory from this site. Most of the points were recovered from the burned rock stratum (RZ and levels immediately above and below) on what is presumed to have been a stable surface at one time. The interesting contrast with $41 \mathrm{CM} 111$ is that here the assemblage is predominately early split stem while at 41CM111 it is Early Triangular, and at the Barton site it is Bell/Andice.

The Camp Pearl Wheat assemblage was small, numbering only seven projectile points, including Martindale $(\mathrm{n}=3)$, Uvalde-like $(\mathrm{n}=2)$, and Bell $(\mathrm{n}=1$; Collins et al. 1990). This assemblage is chronologically earlier than 41CM111, and may reflect some temporal admixture by the presence of the Bell point. Bell and Martindale were stratigraphically separate at the Landslide site.
The John Ischy site (Sorrow 1969) consisted of an extensive and long-accumulating burned rock midden measuring approximately $230 \mathrm{~m}$ in diameter and about $2 \mathrm{~m}$ thick, and associated with a 2 -m-thick ashy midden deposit. The excavations were not sufficiently systematic to allow confident comparable information-with one interesting exception. The excavator (Sorrow) noted a difference in the stratigraphic occurrence of triangular point types Baird and Taylor (combined in the Early Triangular designation used in this report) and Nolan in the earliest period of occupation at the site. Sorrow also noted that a single "Bell" point was recovered from the same stratigraphic unit. Sorrow (1969:44) states:

Two provisional types of triangular points (2-15 Taylor and 2-16 Baird) are the principal markers from this period. One Bulverde and one Nolan point were also collected from this unit, but these types are more predominant in the next period [emphasis added].

The Landslide site (Sorrow et al. 1967:3-43) yielded the best stratigraphic information on the Early Archaic components of any of the site in the comparative file. This site, located in a T2 terrace of the Lampasas River, contains stratified archeological and geological layers. Convincing stratigraphic separation occurred between the Bulverde/Nolan, Bell/Early Triangular (Untyped 3), and Gower/Martindale components providing good chronological information regarding the relative age for these types.

Temporal separation of the Gower/Martindale and Bell/ Early Triangular components at the Landslide site was confirmed by recent investigations at the Cibolo Crossing site (41BX377; Kibler and Scott 2000). The Cibolo Crossing site is a stratified alluvial/colluvial deposit formed along Cibolo Creek in the Camp Bullis Military Reservation. Both components are well represented by diagnostic assemblages. The Martindale component yielded two Martindale, one Bandy, and an untyped point. The Bell/Early Triangular assemblage is represented by one Andice, two Baird (Early Triangular), nine Bell, and an untyped specimen. A stratigraphic unconformity separated the Bell/Early Triangular component from the Late Archaic components. 
Two small burned rock midden sites, Shep and Wounded Eye, yielded Early Triangular assemblages with admixtures of Nolan points (Luke 1980). Andice and Bell, among other point types, were also present at Wounded Eye. While three separate strata were recognized in the stratigraphy at Shep, no vertical proveniences were given for the diagnostic point forms at either site, and the collections therefore have no temporal integrity. At Wounded Eye, for example, a glass bead was recovered from near the bottom of the burned rock midden. Neither of these sites provides useful comparative information due to the lack of vertical separation and apparent mixture of the deposits.

The Upper Medina paleosol at the Richard Beene site (41BX831) dates to the Middle Archaic $4750 \pm 70 \mathrm{BP}$ (Thoms et al. 1996). While the paleosol yielded few diagnostics that would help to better define the chronological separation of Middle Archaic point styles, it does provide a well-dated period of stability that correlates with one of Ricklis and Collins' (1994) periods of stability of 5500-4500 BP. The Lower Medina component yielded a solid assemblage of early bifurcated stem points (Gower/Uvalde), chronologically consistent with the Landslide site.

Of the sites reviewed here, all have some or all of the Middle Archaic point types present at 41CM111, but in different proportions. If we assume that the Landslide and Richard Beene sites represent the real chronological situation, then we can look at the sites in a slightly different way. The mixed components at 41CM111, Sleeper, Barton, Camp Pearl Wheat, Wilson-Leonard, Shep, Wounded Eye, and Woodrow Heard are assumed to be the result of repeated occupation on relatively stable surfaces. Assuming that the excavated collections are grossly comparable, each have Bell/Andice/Early Triangular components represented, but the point types occur in different frequencies. Bell and Early Triangular occur at 41CM111 and Woodrow Heard, but Early Triangular dominates; at Landslide, Barton, and Cibolo Creek, just the opposite is the case. Is this a regional pattern of overlap, or are two groups with traditionally different technologies occupying the same general region of the state during the same interval? Virtually the same argument can be made with Nolan/Bulverde; Nolan is more common in the southern part of Central Texas whereas Bulverde and Bulverde-like are more common to the north. The second question is are Bell and Early Triangular contemporaneous or is it possible that their apparent co-occurrence in the site is a product of mixed deposits? The answer to this question will have to wait for more investigation of alluvial sites with rapidly accumulated deposits where finite temporal separation may occur. Sites such as Baylor (Story and Shafer 1965) and 41MM340 (Tomka et al. 2002) yielded this kind of resolution. This does not mean, however, that sites with seemingly mixed assemblages in buried paleosols are not worthy of research and cannot contribute significant information. Indeed, the more of these sites that are investigated, the better the understanding of the cultural and natural formation processes, and the more comparative information we have available. The subtleties of temporal and regional patterning in the chipped stone assemblages and feature formation and degradation can eventually be teased out, as the history of archeological research in Central Texas has shown. This is not the time to dismiss sites just because they appear to be similar to sites previously investigated. Indeed, none of the Middle Archaic sites compared in this study were alike; all yielded different assemblages in different proportions, but together have helped to illuminate the archeological and geoarcheological processes.

In an effort to tease out some vertical separation in the projectile point assemblage at $41 \mathrm{CM} 111$, the sample from the main excavation block was examined separately. The logic to this exercise is that the block was relatively uniform horizontally and the cultural material was confined to about a $30-\mathrm{cm}$-thick layer. We hoped that it might be possible to seriate some of the temporal diagnostics in this relatively uniform block. The results of this exercise were tantalizingly positive, but the diagnostic sample is small (10 specimens); so small in fact that any vertical separation that occurs has to be taken, in part, on the basis of faith, faith that the separation which fits our chronological model is real. In this exercise the Langtry point occurred above the Nolan, and Nolan/Pandale and Early Triangular occurred only in the deeper levels with Pandale (see Figure 8-7). This separation hints of a vertical separation at least between the upper late Middle Archaic (Langtry) and lower early 
Middle Archaic (Nolan/Pandale-Andice/Bell/Early Triangular) components. The single Langtry specimen signals the presence of an upper late Middle Archaic component dating to approximately $4000 \mathrm{BP} \pm 500$ years (Dibble 1967:Figure 28; Turpin 1982:Table 2).

The following brief discussion centers on both the Nolan/ Pandale and Bell/Early Triangular components that may have had overlapping distributions at the site and may be responsible for the majority of the occupation residue found between 70-100 cmbs, and perhaps even 50-70 cmbs. The two radiocarbon dates recovered in close proximity to two Early Triangular specimens $(4780 \pm 40$ $\mathrm{BP}$ and $4840 \pm 40 \mathrm{BP}$ ) are right on the date range suggested by Collins et al. (1998:Figure 4-1). Another date (Beta No. 166717; $4770 \pm 60 \mathrm{BP}$ ), virtually identical to the Early Triangular dates above, was obtained at the same elevation as a Bell point in Unit 8. The entire suite of dates, with the single exception of Beta Sample No. $166720,4340 \pm 70 \mathrm{BP}$, varies about 400 years (see previous radiocarbon discussion). The anomalous date could be providing the age of the Nolan/Pandale component, although as discussed in the radiocarbon results the comparative stratigraphic placement of the feature yielding this date is anything but clear. The radiocarbon dates from 70-90 cmbs do not negate the possibility of two overlapping early Middle Archaic components being present at the site. The date/point associations are sufficient, however, to argue that the Bell-Early Triangular component was a major contributor to the archeological record at 41CM111. This observation is further strengthened by the proportion of Early Triangular projectile points and preforms compared to other point types within the site.

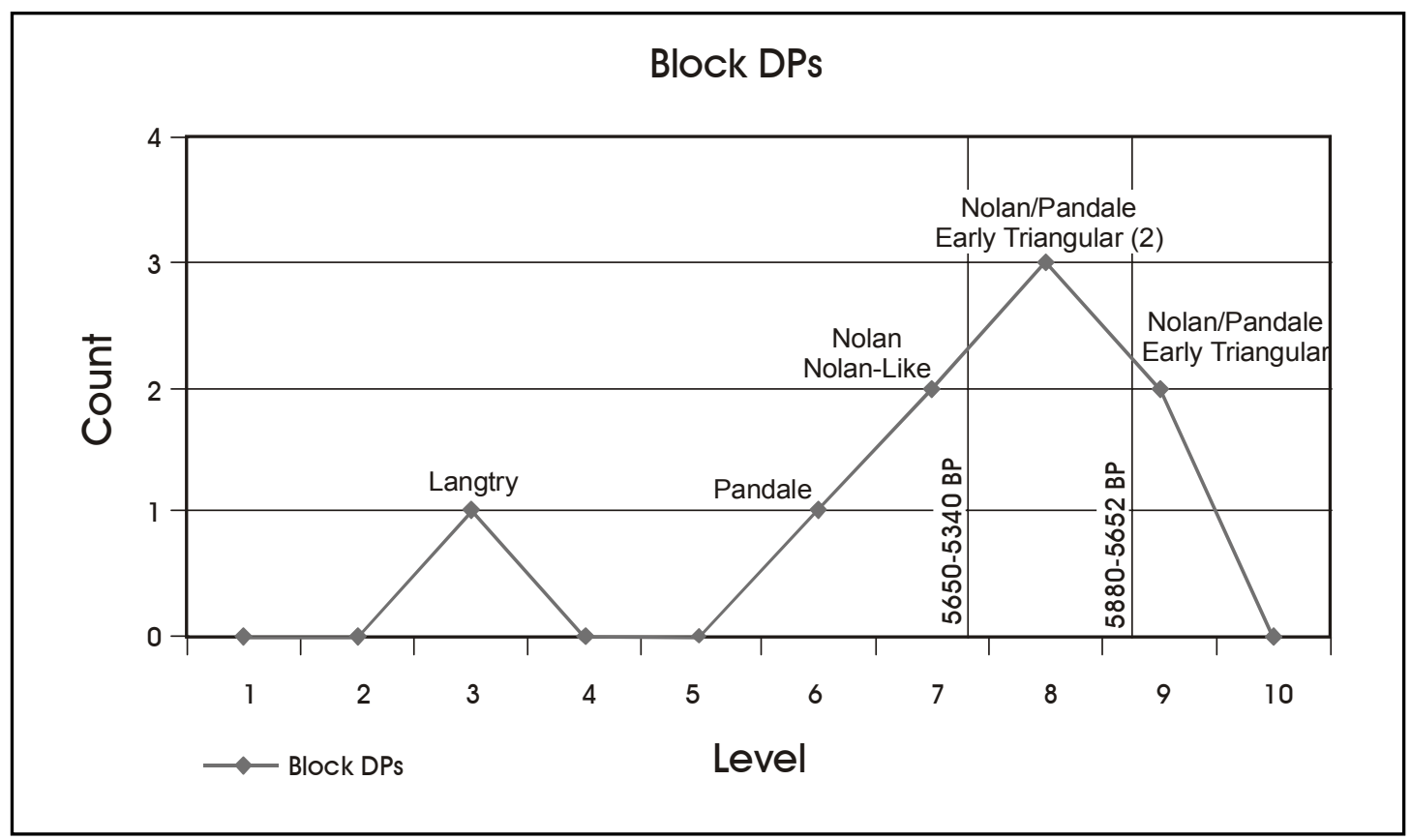

Figure 8-7. Distribution of diagnostic projectile points (DPS) in block excavation with associated radiocarbon dated surfaces. 


\section{Summary}

In this chapter we examined the stratigraphic context, radiocarbon assays, and temporally diagnostic artifacts recovered from 41CM111 to discern information regarding the number of archeological components present at the site, the associational integrity of these components, the ages of these materials, and the site formation processes that may have been responsible for the deposits investigated.

The data suggest that two clearly separable components can be identified at the site, an early Late Archaic and an early Middle Archaic. The early Middle Archaic component may in turn contain two admixed (inseparable) components. The upper component is poorly represented in terms of diagnostic artifacts while the lower component appears to contain Nolan, Pandale, Early Triangular, and Bell/Andice points in a mixed context. The upper component is manifested between 30-50 cmbs, while the lower component extends from $50-110 \mathrm{cmbs}$. As indicated by the distribution of Early Triangular preforms, it is also possible that the lower component has two peaks, one between 50-70 cmbs and another from $80-110 \mathrm{cmbs}$. Although Early Triangular forms may occur lower than the Nolan/ Pandale points, it is not possible to clearly separate these chronologically distinct components. We suspect that the two components (Nolan/Pandale and Andice/ Bell/Early Triangular) were separate, but that small sample size, some vertical displacement of the diagnostic projectile points, and relative stability of the occupation surface in the main block excavation may have contributed to our inability to successfully segregate the two assemblages stratigraphically.

41CM111 fits a pattern that is emerging in this part of Central Texas for Middle Archaic and mixed Early and Middle Archaic sites. There appears to be a relatively stable landform on upper terraces in small and medium size creek valleys ca. $5000 \mathrm{BP}$. This might relate to the broad periods of stability referred to earlier, from ca. 5500 to 4500 BP (Nordt 1992, 1993; Ricklis and Collins 1994). The preponderance of lithic material, including both chipped stone and burned rock, may have been deposited on a slowly evolving, if not almost stable, land surface. We were unable to convincingly differentiate the two components stratigraphically as noted earlier, although refits indicate that the deposits have at least some integrity with regards to mixing. Some mixing is evident, however, in the vertical distribution of refit pieces.

Sites with either Early, mixed Early/Middle, or Middle Archaic components occur in isolated situations (e.g., Sleeper, Camp Pearl Wheat, and 41CM111). These components also occur in sites that continued to be occupied throughout much of the Archaic sequence (La Jita, Woodrow Heard, Barton, Wilson-Leonard, Gault, Landslide, and Youngsport). Sites repeatedly occupied for long periods may have been in naturally favorable locations on the landscape. Johnson (1991) is correct in reminding us that Archaic people were highly flexible; their movements and economy were strategically mapped onto the landscape. As ecological circumstances changed so did the economic patterns, the land-use strategies and the places occupied across the landscape. 



\title{
Chapter 9: $\quad$ Burned Rock Features
}

\author{
Richard B. Mahoney, Harry J. Shafer, and Steve A. Tomka
}

\section{Introduction}

The primary objective of this chapter is to assess the nature, characteristics, and validity of burned rock "pavements" or sheet middens as an identifiable Archaic feature type. To this end, a series of prehistoric sites are reviewed that span both time and space across Central Texas. In considering these various sites, it became necessary to establish a consistent language that would allow for accurate evaluations of their form, content, and function relative to their temporal affiliation. The terminological framework precedes the site reviews. Following the reviews, we consider the nature of the 41CM111 burned rock features in light of the broader context, but with specific focus on the formation processes that may have been responsible for these features.

\section{Burned Rock Midden and Feature Terminology}

Whether it is a component of hearth features, or it occurs in scatters, clusters, or heaped accumulations, heat fractured or burned rock is a common artifact on Archaic sites in Central and South Texas (e.g., Black 1989). It is perhaps their ubiquity, the variety of formation processes responsible for them, and the large number of archeologists that have had to deal with them, that has led to a wealth of terms used to refer to these features. Burned rock accumulations have been described and interpreted as dumps, sheet middens, intersecting hearths, pavements, and burned rock middens. Distinction among feature types is requisite for systematic and consistent intra- and inter-site comparisons and behavioral interpretations. Thus, the use of consistent and accurate descriptive terms for what these remnants of behavioral patterns and subsistence strategies represent is central to our understanding of prehistory.

\section{Burned Rock Midden}

A "burned rock midden" is here defined as a stratigraphically isolable lens or stratum of burned rock and/ or a regular or irregular accumulation of burned rock refuse formerly associated with thermal features. Four distinct types of burned rock middens are differentiated: sheet middens, dome middens without central hearths, dome middens with central hearths, and crescent/ ring middens.

Sheet middens are formed through the displacement and commingling of burned rocks from hearths and/or discrete single episode dump features. The displacement can be attributed to either natural (e.g., fluvial/erosional) or cultural (e.g., hearth maintenance) agents. Occupation features may be evident within the sheet midden, as the midden occupies the activity area in which its constituent burned rocks were originally used.

Dome middens without central hearths represent thick, domed accumulations of burned rock formed through the repeated maintenance or selective discard of burned rock into well-defined discard areas spatially segregated from the original features from which the burned rock derives.

Dome middens with central hearths represent accumulations of "exhausted" burned rock in the immediate vicinity of the rock oven thermal facility. The critical difference between the dome midden without a central hearth and the sheet midden is that the first (i.e., dome) represents evidence of purposeful site maintenance while the other (i.e., sheet midden) indicates no concern for activity area maintenance.

Ring middens represent crescent or ring-shaped accumulations of burned rock discarded from the repeated use of rock as linings for earth ovens. At a very basic level, the critical distinction between ring middens and dome middens with central hearths is the overall shape and pattern of burned rock discard associated with oven maintenance.

The burned rock accumulations representing dome middens with or without central hearths and ring middens may in turn be employed as settings for some thermal features since they consist of formerly discarded heating elements (i.e., rocks). Therefore, it should not be ruled 
out that the rock mounds or rings themselves may contain hearths representing the expedient and convenient use of the rock as a source of heating elements.

\section{Burned Rock Hearth}

Discrete concentrations of thermally altered stone in association with in situ oxidized soil have traditionally been defined as burned rock hearths. Burned rock hearths are typically grouped on the basis of form (i.e., arcuate, flat, and basin; Prewitt 1982). As used here, hearths can represent both cooking features as well as heat treatment features employed in raw material processing, or a combination of both.

\section{Burned Rock Cluster or Concentration}

A concentration of intentionally deposited burned rock lacking association with in situ oxidized soil or charcoal is defined as a burned rock cluster. Due to its secondary context, it is often difficult if not impossible to identify the primary feature responsible for the burned rock. Such clusters or concentrations may represent secondary dumps resulting from hearth maintenance. In other instances, the clusters may represent the discard of boiling stones after their use life was expended (Quigg et al. 2000).

\section{Burned Rock Scatter}

The dispersed remains of a hearth or a burned rock cluster constitute a burned rock scatter. In contrast to the burned rock cluster, the scatter exhibits no apparent intentional concentration of burned rock. It is assumed that the dispersed nature of the materials is most likely postdepositional in origin, whether by intentional cultural means or unintentional natural means. While sheet middens contain the commingled remains of several burned rock features and also are rich in occupation debris, burned rock scatters often represent the displaced remains of one or a small number of hot rock features and typically possess no other evidence of occupational debris. Due to the diffuse nature of these disturbed feature types, identification of their original function is often impossible.

\section{Burned Rock Pavement}

As defined by Kleinbach and others (1995:776), a burned rock pavement is comprised of "an extremely dense arrangement of burned rock, typically one to two tiers thick, that appears to have been intentionally fitted together, jigsaw-style, to form a flat, moderately articulated surface." Their structure is that of a systematically arranged surface, as opposed to the irregular accumulations evident in burned rock middens. Charred materials are infrequently encountered in association with pavements (e.g., Bement 1984; Clabaugh 1994). The function of the pavements is difficult to discern, although Clabaugh (1994:92) suggests a possible platform function for the stone arrangement.

\section{Regional Variations}

To gain an idea of the morphological/functional and regional variability in Archaic period burned rock features across the Central Texas Archeological Region, 32 sites were reviewed. To be included in this review, sites had to meet the following four criteria: 1) the presence of burned rock features; 2) apparent depositional integrity; 3) temporal control via radiometric assays and/or diagnostic stone tools; and 4) accurate descriptions provided by the respective author(s). Each brief site review will discuss locational data, temporal affiliation, diagnostic stone tools, and feature type(s).

\section{The Jetta Court Site (4ITV151)}

This site possesses two stratified burned rock sheet middens apparently spanning the length of the Archaic era (Wesolowsky et al. 1976). While no radiometric assays were included in the investigations, numerous temporally diagnostic projectile points were recovered in seemingly reliable contexts. The initial occupation of the site is ascribed to the Early Archaic, with Gower and Bell dart points recovered within the lower sheet midden. The midden occurs as an approximately 40 -cm-thick lens composed primarily of burned limestone along with other cultural debris such as debitage and faunal remains. A second, later midden is stratigraphically situated above and separate from the lower midden. The later midden is approximately $75 \mathrm{~cm}$ in thickness, with a similar 
content of cultural debris as the earlier midden. The authors mention some degree of turbation within the upper midden; however, the proveniences of the recovered projectile points appear to roughly align in chronological order. Dart points diagnostic of the Late Archaic generally occur within the lower portion of the midden and include Pedernales, Montell, Darl, Castroville, Ensor-Fairland, and Lange. Of note are two Travis points that may have been the result of recycling (e.g., Hester 1995; Ricklis and Collins 1994). The first excavated level of the upper midden contained Late Prehistoric arrow points including Scallorn and Perdiz. A total of six burned rock features was recorded during the brief excavations. Of these, four were recorded as flat or surface hearths, although there is no mention of in situ oxidized soil in association. The remaining two features were apparently burned rock scatters. No specific temporal affiliation can be ascribed to these features, but, due to their stratigraphic position, they would range between the Early and Late Archaic periods.

\section{The Greenhaw Site (41HY29)}

The Greenhaw site consisted of a group of eight discrete burned rock sheet middens with artifacts ranging from Paleoindian through the Toyah phase of the Late Prehistoric (Weir 1979). The majority of the occupations associated with the various burned rock middens consisted of Archaic materials. The assemblage spanned the Archaic period from Early Archaic Angostura points through Transitional Archaic Frio dart points. Weir (1979:17) suggests that an additional feature, Midden E, represents a possible dome midden with an earth oven; however, the cross-sectional profile does not appear consistent with other annular earth ovens (Weir 1979). Of the eight sheet middens, six were tested and contained probable occupational features within the stratified layers of burned rock.

\section{The Crumley Site (41TV86)}

The Crumley site occurs as an apparent stratified dome midden without a central pit feature with at least five definable strata (Kelly 1961). Three of these strata were judged to represent occupation surfaces with associated accumulations of burned rock. An intervening sterile layer of sediments separates the two lower surfaces. No hearths or features were encountered within the deposits.
A single radiometric assay from a charcoal sample extracted from the bottom of the lowest occupation surface returned an uncalibrated date of $3275 \pm 125 \mathrm{BP}$. Over 600 projectile points were recovered during the excavations, with representative specimens ranging from the late Paleoindian through the Transitional Archaic periods. Chronological sequencing of the diagnostic stone tools is in fairly good order, with Early Archaic dart points occurring generally beneath the Late Archaic materials.

\section{The Loeve Site (4IWMI33)}

Often overshadowed by the more extensive excavations at its sister site (the Loeve-Fox site [41WM230]), the Loeve site produced significant, albeit limited, data for the Early Archaic in Central Texas (Prewitt 1982). Located on a point bar along the San Gabriel River in eastern Williamson County, 41WM133 was one of three sites reported by the TAS for the San Gabriel Reservoir Project. Germane to our discussion, the Loeve site contains an isolable Early Archaic component with diagnostic projectile points consisting of Angostura-like specimens. Several hearths dot the limited areal extent of the occupation surface exposed during fieldwork. The density of extant feature-associated, as well as probable unrelated burned rock, forms a thin veneer across the Early Archaic occupation surface forming a burned rock sheet midden. The most significant aspect of the sheet midden is the apparent internal structure with defined activity areas.

\section{The Landslide Site (41BL85)}

Along with Evoe Terrace and Youngsport (see following descriptions), the Landslide site is located in association with the Lampasas River in southwestern Bell County (Sorrow et al. 1967). At least five occupations are suggested at this terrace locale, ranging from Early through Late Archaic. Several burned rock hearths and burned rock concentrations were recorded, including one (Feature 2) wherein bison bone and a Bell point were recovered. Most striking about this feature, though, is the $1.5-\mathrm{m}$ diameter pavement constructed about the periphery of the central hearth. A single course of flat rock was positioned in a roughly circular configuration. The burned rock hearth feature was located in the center of the circle, with evidence of in situ firing. A Late 
Archaic burned rock sheet midden contained primarily Pedernales points, but Nolan and Early Triangular specimens occurred below them.

\section{The Evoe Terrace Site (41BL104)}

Located along the Lampasas River in southwestern Bell County, the Evoe Terrace site occupies a high terrace approximately $11 \mathrm{~m}$ above the modern-day average waterline (Sorrow et al. 1967). Similar to the cultural stratigraphy exhibited at the Landslide site, the stratified deposits represent occupations spanning Early Archaic through Late Prehistoric. A more pronounced burned rock sheet midden occurs late in the sequence, with Pedernales again comprising the majority of diagnostic projectile points associated with the midden. One specimen each of Montell and Lange were recovered in the midden deposit as well. Late Prehistoric occupations were situated above the midden, with a predominance of Scallorn points representing the Austin phase and Perdiz points and ceramic sherds representing the later Toyah phase.

\section{The Youngsport Site}

One of the first reported sites along the Lampasas River in Bell County, the Youngsport site is a terrace locale comprised solely of Archaic occupations (Shafer 1963). Stratified cultural deposits comprise the upper $2.6 \mathrm{~m}$ of the site. A dense stratum of cultural material (Stratum 3B), with a concentration of burned rock throughout, occurs in the central portion of the vertical column and terminates at roughly $1.2 \mathrm{~m}$ below ground surface. The concentration appears to represent a burned rock sheet midden. The diagnostic stone tool assemblage of the stratum is dominated by Pedernales points $(n=41$; $67 \%$ ). The most salient characteristic of this site is the stratigraphic sequencing of the diagnostic stone tool assemblage.

\section{$41 B X 1$}

This prehistoric multicomponent site is located atop the upland valley margin and floodplain adjacent Olmos Creek, a tributary of the San Antonio River, in central Bexar County (Assad 1979; Luke 1974; Lukowski 1988; Orchard and Campbell 1954, 1960; Woolford 1935). Cultural material spanning the Paleoindian through the Toyah phase of the Late Prehistoric comprises the artifact assemblage recovered from 41BX1. The onset of intensive occupation is suggested with the formation of a burned rock sheet midden during the Middle Archaic. Radiocarbon assays and Nolan dart points associated with the sheet midden parallel the occupation at 41CM111. Subsequent occupations at 41BX1 apparently did not share similar adaptation with the Middle Archaic peoples, as no indication of significant burned rock accumulation is attributable to these later occupations. Numerous burials, replete with grave goods, have been ascribed to the Late Archaic period. The presence of ceramic sherds within the deposits suggests continued use of the site through the Late Prehistoric, again with no indication of burned rock accumulation.

\section{The Culebra Creek Site (41BXI26)}

A multicomponent Archaic era site (41BX126) was recorded along Culebra Creek in the western portion of Bexar County (Nickels et al. 2001; Wood 1994). A locale containing a dome midden with a central earth oven and at least 11 surrounding burned rock clusters and burned rock hearths was revealed - through corroborative radiometric assays and temporally diagnostic stone tools - to be related primarily to the Late Archaic period. Of particular note at this site is an earlier component containing primarily Nolan dart points and burned rock clusters and hearths, which underlie the majority of the later clusters and the single earth oven. This component is coeval with the cultural deposits at 41CM111.

\section{The Kennedy Bluffs Site (41BP19)}

This upland site is located in proximity to the confluence of Alum Creek and the Colorado River in southeastern Bastrop County (Bement 1989). While the temporally diagnostic stone tools suggest a span of occupations from the Early Archaic through the Late Prehistoric, evidence for the majority of the cultural material may be ascribed to the Late Archaic. The primary feature at 41BP19 is a burned rock sheet midden. Within the midden, several discrete features were noted during excavation including burned rock hearths and burned rock clusters. By virtue of the various stone tools and absolute dates, it is apparent that formation of the sheet midden was a cumulative process resultant from successive reoccupation of this preferred upland locale.

\section{The John Ischy Site (4IWM49)}

A significant prehistoric multicomponent terrace site, 41WM49 is located along the North Fork of the San Gabriel River in Williamson County (Sorrow 1969). The 
primary component of the site is the massive burned rock dome midden without an associated central pit feature, which is replete with artifacts yet devoid of other cultural features. Temporally diagnostic projectile points include Middle Archaic through Late Prehistoric types. The predominant point type, however, is the Pedernales of the Late Archaic period, and this is the time frame to which the majority of burned rock accumulation is ascribed. Additional stone tools recovered from the excavations at 41WM49 include drills, awls, burins, choppers, hammerstones, manos, scrapers, and one gouge. The variety of the assemblage indicates a diverse suite of subsistence-based activities presumably associated with midden formation.

\section{The Mustang Branch Site (41HY209)}

The Mustang Branch site is located along a tributary of Onion Creek in northeastern Hays County (Ricklis and Collins 1994). It is a prehistoric multicomponent site located along a terrace and the adjoining bluff. The burned rock features associated with the bluff portion of the site tell an intriguing tale of site use and, inferentially, subsistence. Based on analysis of temporally diagnostic projectile points, it is apparent that the associated burned rock dome midden formed primarily during the Transitional Archaic. The midden, as a whole, has the appearance of a dome midden; however, a single in situ hearth feature appears consistent with central hearth features typically encountered in dome middens associated with central earth ovens. The hearth evidenced little use, though, and the researchers suggest a dome midden used primarily as a dump for "exhausted burned rock" (Collins 1994:171).

\section{$41 B \times 300$}

Located along Salado Creek and in proximity to the Panther Springs Creek site (41BX228), a single burned rock sheet midden was encountered with nine associated burned rock hearths and burned rock scatters (Katz 1987). Katz (1987:147) interprets the accumulation of the approximately $255-\mathrm{m}^{2}$ midden as a communal dump comprised of burned rock refuse from surrounding activity areas. No evidence of in situ burning, such as oxidized soil, was evident in the numerous excavation units placed throughout the midden. Each of the surrounding hearths, however, exhibited attributes consistent with in situ firing. Interestingly, while Katz (1987:150) contends that the midden is a by-product of the surrounding features and, through relative dating of diagnostic stone tools, a Late Archaic temporal association of these peripheral features is here inferred, he maintains a Middle Archaic affiliation of the midden. This interpretation is due, in part, to the recovery of a Travis dart point from underneath the midden at contact with the underlying substrate. In addition, reclassification of dart points such as Pedernales and Lange from the Middle Archaic to the Late Archaic would further explain this discrepancy. In any case, the current interpretation of the feature complex is that of a primarily Late Archaic manifestation.

\section{The Sleeper Site (41BC65)}

The Sleeper site, an apparent single-component Early Archaic site, is located along Walnut Creek in northern Blanco County (Johnson 1991). The feature complex consists primarily of a burned rock sheet midden with discernible burned rock clusters and burned rock features contained within and immediately atop the midden. The midden, then, is most likely comprised of a number of dispersed burned rock clusters and burned rock hearths in proximity to one another, thereby forming the residue stratum of burned rock. An Early Archaic dart point assemblage consisting primarily of Early Split-Stem points (Collins 1995:383) dates the site to roughly $7000 \mathrm{BP}$.

\section{The Camp Pearl Wheat Site (41KR243)}

Excavations along Town Creek in Kerr County revealed the remnants of an Early Archaic open campsite, Camp Pearl Wheat (Collins et al. 1990). Six features were recorded in the field as discrete burned rock clusters or burned rock hearths; however, in reference to Figure 11 (Collins et al. 1990), the approximately $36-\mathrm{m}^{2}$ accumulation of burned rock would itself appear to form a burned rock sheet midden. Albeit less dense, the midden appears similar to the one at the Sleeper site, with burned rock features within the midden. Each of the typed projectile points (Martindale, Uvalde, and Bell) is consistent with the current interpretation of the Early Archaic period in Central Texas.

\section{The Hop Hill Site (4IGL21)}

This site is located along the Pedernales River in southeastern Gillespie County. The Hop Hill site is located along the upland margin and valley slope adjacent the Pedernales floodplain (Gunn and Mahula 1977). Excavations at the site revealed four stratified occupation 
surfaces, each represented by a burned rock sheet midden. Discrete features were noted within the middens and consisted of burned rock hearths and burned rock clusters. Sixty-two typable projectile points were recovered from the site, although only two from primary context; the remainder were recovered from ground surface along the eroded valley slope. While a span of Early Archaic through Late Prehistoric is represented in the artifact assemblage, the majority of the projectile points indicate a primarily Transitional Archaic and Austin phase component for formation of the middens.

\section{The Jonas Terrace Site (4IME29)}

The Jonas Terrace site represents a prehistoric multicomponent terrace occupation along a small tributary of San Geronimo Creek in northeastern Medina County (Johnson 1995). Burned rock features include hearths, clusters, a sheet midden, and a dome midden without an associated central pit feature. Radiocarbon assays and temporally diagnostic stone tools indicate occupations spanning the Middle Archaic through the Late Prehistoric. Accumulation of the middens, however, is ascribed to the early Late Archaic period. Middle Archaic materials underlie the middens, while Late Prehistoric materials lie atop and intrusive into the upper portion of the middens.

\section{The La Jita Site (4IUV21)}

Located along the Sabinal River in Uvalde County, the La Jita site is a multicomponent terrace site (Hester 1971). Three burned rock dome middens without central pits and three hearths were encountered during the excavations. Consistent with the "communal dump" scenario, Hester's (1971:125) "rubble dump" concept aptly describes the situation of hearths and other activity areas separate from the middens. This setting would conveniently explain the paucity of other cultural material among the burned rocks in the middens. Through analysis of the diagnostic projectile points, the occupations at $\mathrm{La}$ Jita suggest a span from the Early Archaic through the Late Prehistoric periods (Hester 1971). Brief occupation during the Early Archaic is suggested by the scant remains attributable to that period, including Angostura and Angostura-like projectile points. Hester infers the affiliation of the burned rock middens with the Middle Archaic, although none of the radiocarbon assays date to that period. The majority of the dates, in fact, suggest a Transitional Archaic component, subsuming the latter portion of the Late Archaic and the early portion of the Late Prehistoric. Without radiocarbon assays from the middens proper, however, it is difficult to define the temporal association of the refuse dumps. It is inferred that, for the use of this report, the middens are related to Late Archaic occupation(s) based on the predominance of Pedernales and Montell dart points.

\section{The Shep Site (41KR109)}

Located between two minor tributaries of the Guadalupe River in southeast Kerr County, the Shep site is a multicomponent interfluviatile terrace site (Luke 1980). The primary feature at the Shep site is a burned rock dome midden without an associated central pit feature. In reference to the central pit anomaly depicted in the cross-sectional wall profile (Luke 1980:Figure 8), the feature probably began life as an earth oven and was subsequently transformed into a burned rock dump midden. Temporally diagnostic artifacts consisted primarily of Early Triangular points $(n=5)$ recovered in association with Nolan-like, Travis-like, and Angosturalike dart points, indicating an Early Archaic formation of the burned rock dump midden.

\section{The Wounded Eye Site (41KR107)}

Similar to the Shep site, 41KR107 is an interfluviatile terrace site located between two minor tributaries of the Guadalupe River in southeast Kerr County (Luke 1980). The central feature at the Wounded Eye site is a burned rock dome midden without a central pit feature. Numerous burned rock clusters also are present on site. Comparable to 41KR109, the Wounded Eye site's typable formal stone tool assemblage was dominated by Early Triangular specimens $(\mathrm{n}=27)$ recovered in association with Nolan-like, Langtry-like, Angostura, and Bell dart points. An Ensor point was located atop the ground surface away from the midden. This, along with the separate cluster feature, may indicate a much later Transitional Archaic reoccupation of the site whose formation is attributable to the Early Archaic.

\section{The Medio Creek Site (41BXI421)}

A prehistoric multicomponent campsite, 41BX1421, is situated atop an interfluviatile terrace in southwest Bexar County (Mahoney 2002). A single burned rock sheet midden comprises the remnant portion of the site area tested. Based on two columns of radiocarbon assays $(n=9)$ and corroborative temporally diagnostic projectile 
points, the site has been ascribed to the Transitional Archaic, with formation of the midden occurring very early within that period. A later Toyah phase component is expressed at the site but is not associated with the single midden feature. The midden stretches along the terrace for approximately $30 \mathrm{~m}$ and averages roughly 20 $\mathrm{cm}$ in thickness. No distinct features were encountered within the burned rock midden, and it is consistent with a communal dump accumulation.

\section{The Bull Pen Site (41BP280)}

The Bull Pen site is a prehistoric multicomponent site located along a terrace of the Colorado River in central Bastrop County (Ensor and Mueller-Wille 1988). Ten discrete burned rock features were recorded within the deposits, including in situ hearths and burned rock clusters. The primary component of the site is attributed to the Late Archaic with less than five percent of the typable projectile points and only one of the ten features related to a Late Prehistoric component. Radiocarbon dates verify both components present. Of note at the Bull Pen site is the discrete nature of the individual features. Based on the plan views and photographs, none of the features appear dispersed or commingled. These data suggest specialized activities within the areas tested. The abundance of projectile points $(\mathrm{n}=89)$ in combination with manos $(n=9)$ and metates $(n=2)$ indicates that hunting was of primary significance with the processing of vegetal materials secondary in subsistence importance.

\section{$41 B T 6$}

Site 41BT6 is a multicomponent prehistoric and historic terrace site located along Backbone Creek, a tributary of the Colorado River, in southern Burnet County (Young 1985). An interesting yet abstruse anomaly at this site is the centrally located sheet midden of granite and quartz rocks. Per the published site report (Young 1985), it remains unclear whether the rocks comprising this feature are burned or unburned. The surrounding burned sandstone hearth features would suggest the former, but this is speculative. In reference to Figure 6 in that report, Young (1985:20) depicts the sandstone hearths amid a general burned rock sheet midden separate from the granite and quartz sheet midden. This surrounding sheet midden is comprised entirely of burned sandstone, with no presence of granite or quartz outside of the prescribed margin. As in the Slab site (see site discussion), 41BT6 contains diagnostics of the Early Archaic that are believed to be recycled. The midden appears to have formed during the Transitional Archaic, with representative dart points (i.e., Ensor, Frio, and Fairland) occurring alongside various arrow points.

\section{The Cibolo Crossing Site (41BX377)}

Contained within the Camp Bullis Military Reservation, prehistoric multicomponent site 41BX377 is located along a terrace of the Cibolo Creek in northern Bexar County (Kibler and Scott 2000). Numerous burned rock feature types were encountered during the data recovery investigations including hearths, clusters, scatters, and a dome midden without a central pit feature. Based on temporally diagnostic stone tools and corroborative radiocarbon dates, the occupations fall within the Early Archaic and Late Archaic periods. Indication of Paleoindian and Late Prehistoric components were encountered as well, although with no temporally diagnostic tools and no depositional integrity, respectively. Of note among the features is a burned rock dome midden without a central hearth associated with the Bell-Andice component of the Early Archaic period. It is inferred that the midden is the product of successive dump episodes attributable to the various hearths encountered.

\section{The Woodrow Heard Site (4IUV88)}

This is a prehistoric multicomponent site located along a terrace of the Dry Frio River in northern Uvalde County (Decker et al. 2000). Between 51 and 57 burned rock features were encountered during the field operations (cf. Decker et al. 2000:127, 177, 215) and consisted of hearths, scatters, clusters, and middens. Formal stone tools and radiocarbon assays indicate occupation of the terrace from Early Archaic times through the Late Prehistoric. An important aspect of this site is the homogeneity of feature types through time. Specifically, each component consisted of burned rock hearths, burned rock clusters, and burned rock middens.

\section{The Shoppa Site (41BP191)}

This site is situated atop an upland landform adjacent an unnamed tributary of Big Sandy Creek in central Bastrop County (Bement 1984). Temporally diagnostic stone tools in concert with radiocarbon assays indicate Late Archaic to Late Prehistoric use of the site. The entirety of the occupation surface comprises a burned rock sheet midden with 25 discernible features, all of which were interpreted as hearths. Of note to the current study was 
the recordation of four burned rock pavements. Limited amounts of charcoal were noted among the stones comprising the pavement feature types, supporting a platform function.

\section{The Panther Springs Creek Site (41BX228)}

Located near the confluence of Panther Springs and Salado Creek, the Panther Springs Creek site is a prehistoric multicomponent terrace site in north-central Bexar County (Black and McGraw 1985). The archeological investigations at 41BX228 focused on the four burned rock dome middens without associated central pit features located along Panther Springs Creek. In addition, the site contained burned rock clusters, burned rock scatters, burned rock hearths, and a burned rock sheet midden was apparent across a portion of the site (Black and McGraw 1985:253). While occupation at this locale spanned the Early Archaic through the Toyah phase, formal stone tools and radiometric dates associated with the midden accumulations suggest formation during the Middle Archaic and early Late Archaic periods. Of note at this site is the contemporaneity of the apparent initial occupation(s) with those of $41 \mathrm{CM} 111$.

\section{The Granberg Site (41BX17)}

This prehistoric multicomponent terrace site is located along Salado Creek in central Bexar County (Schuetz 1966). A single burned rock dome midden without a central pit feature represents the most salient cultural feature encountered. As with the majority of the other sites reviewed here, Granberg exhibits some intermixing of the various strata; however, the sequencing of the temporally diagnostic artifacts appears in generally good context. Like 41CM111, a primary projectile point type associated with the burned rock midden deposit is the Nolan. Unlike 41CM111, though, is the absence of Early Triangular points. In their stead, however, are Lerma and Langtry point types.

\section{The Granberg II Site (41BX27I)}

Similar to its sister site, Granberg II is a multicomponent terrace site located in close proximity to $41 \mathrm{BX} 17$ along Salado Creek (Hester and Kohnitz 1975). Eleven discrete strata were identified in the 3.6-m deep excavations. Among these strata, temporally diagnostic stone tools represent the Early Archaic and the Late Archaic periods. The uppermost cultural stratum was defined as a burned rock sheet midden ascribed to the Late Archaic. Projectile points associated with this macrofeature include Pedernales and Montell. Underlying the sheet midden was a series of alluvial gravel deposits extending from 0.6 to $3.6 \mathrm{~m}$ below ground surface. Cultural material was encountered throughout these deposits, with diagnostic stone tools primarily occurring in the upper portion of the gravels. Recovered Early Archaic diagnostic dart points include Bell, Early Triangular, and Gower. Other diagnostic lithics include Clear Fork and Guadalupe tools. Interestingly, no Nolan points were encountered during excavation. This is of note due to the predominance of Nolan points and absence of Early Triangular, Bell, Guadalupe, and Clear Fork tools at 41BX17.

\section{The Slab Site (41LL78)}

This is a prehistoric terrace site located along the Llano River in eastern Llano County (Patterson 1987). The most notable, albeit questionable (cf. Johnson 1997), aspect of the site is the presence of structural remains in the form of circular arrangements of burned rock clusters. In reference to Figure 9 in Patterson (1987), several of these proposed structures are depicted with superimposed circles. This possibility is indeed intriguing, yet the individual structural units are difficult to discern and probably represent a palimpsest of occupations at this terrace locale. For the purpose of this report, the burned rock remnants are consistent with a burned rock sheet midden. Nevertheless, the artifact assemblage suggests a strong argument for the contemporaneity of dart points and arrow points in the Texas Transitional Archaic (e.g., Hester 1995). Further evidence for recycling (e.g., Creel et al. 1979) is suggested by the encounter of one Angostura and one Gower point. Interestingly, ceramic sherds, often an indicator of the Toyah phase, were recovered in similar context as the remainder of the Transitional Archaic diagnostics.

\section{The Wunderlich Site (4ICM3)}

The Wunderlich site was encountered along a terrace of Rebecca Creek, a tributary of the Guadalupe River, in northern Comal County (Johnson et al. 1962). Similar to the Medio Creek site, the presence of two discrete burned rock dome middens without central pit features is the only form of cultural feature at the site. These refuse areas again suggest that associated occupational areas were situated outside of, but in close proximity to, the middens proper. Interestingly, nearly 200 projectile points 
and fragments were recovered during excavations at Wunderlich, with roughly 350 percent greater volumetric ratio than the Medio Creek excavations. Although a wide range of temporally diagnostic stone tools comprises the artifact assemblage, formation of the middens is ascribed to the early portion of the Late Archaic.

\section{The Wilson-Leonard Site (4I WM235)}

Wilson-Leonard is a prehistoric multicomponent site situated along Brushy Creek in southwestern Williamson County (Collins et al. 1998). Beginning primarily in the latter portion of the Paleoindian period, the use of locally available limestone in thermal features is apparent. The use of these features increases during the Early Archaic, and as they intersect one another and are dispersed and commingled with one another, form burned rock sheet middens. These sheet middens continue to form throughout the Middle and Late Archaic periods. Certain areas of the site exhibit characteristics consistent with dump areas; thereby forming burned rock dome middens atop and within the associated sheet middens. The occupation of the site begins to wane in the Late Prehistoric, with fewer burned rock hearths being made and, hence, less opportunity for the formation of burned rock middens. The results of these investigations depict a continuum of subsistence throughout the Archaic era in Central Texas.

Table 9-1 provides a summary of the feature types present on the above-summarized 32 sites. It is clear that a variety of burned rock feature types are present on most sites. Among the midden types, sheet middens appear to be most common followed by dome middens without associated central pit features. Dome middens with associated central pits are relatively scarce. However, it is possible that some of the dome middens without central pit features may actually have central pits that have not been identified during excavation. This would make sense since otherwise the prevalence of dome middens without central pit features would be suggestive of extreme degree of site maintenance, a behavioral pattern that is not common among hunter-gatherers.

The multiple varieties of burned rock feature types encountered on many of the sites reviewed here may in part be attributed to the multicomponent nature of some of the sites. It is evident that even on single-component sites multiple feature types tend to be the norm, at least within the small sample reviewed for this report. What are the factors that may lead to the formation of sites with such a broad range and mix of burned rock features?

At least two possible factors may act in concert to lead to the formation of depositional units containing an admixture of temporal diagnostics as well as a range of burned rock feature types: 1) a resource structure or distribution pattern that encourages reuse; and 2) a depositional context that provides stable or slowly aggrading surfaces that are exposed over long periods of time.

Numerous ethnographic case studies from around the world have shown that in situations characterized by abundant and rhythmically productive (i.e., seasonally predictable) resources, hunter-gatherers will systematically return to exploit available resources (see Flannery 1968; the concept of scheduling). Resource types that may be particularly likely to encourage repeated reuse of a patch, and perhaps the same site, include springs with dependable water flow, plant resources (e.g., oak and pecan woodlands), and high quality lithic resources. In some cases, the revisits to a given resource patch are highly regular and seasonal, in other cases the revisits may be separated by longer time periods depending on the rate of resource regeneration and other factors such as insect infestations. While the same exact site may not be reoccupied during each revisit, few circumstances (deaths) may actually prevent groups from doing so, particularly if the resource patch is highly productive. Furthermore, the reoccupation of sites and localities may be encouraged or favored by resource predictability and the presence of site furniture (i.e., burned rock facilities) that may be available for reuse. Sites with multiple archeological components separated by thousands of years of deposition represent a similar yet different phenomenon in that the reoccupation of the landform is probably more reflective of long-term resource potential of the region rather than the seasonal recurrence of a specific resource.

Depending on the location of a particular site and its geomorphic context, living surfaces and their associated discarded cultural materials may remain exposed for long periods or may be buried soon after site abandonment. In some instances, site abandonment may indeed be the result of depositional processes (i.e., landslides, floods, 
Table 9-1. Breakdown of midden and feature types within sites consulted in literature survey

\begin{tabular}{|c|c|c|c|c|c|c|c|c|c|c|c|}
\hline \multirow[b]{2}{*}{ Site } & \multicolumn{2}{|c|}{ Component } & \multicolumn{4}{|c|}{ Midden } & \multicolumn{4}{|c|}{ Feature } & \multirow[b]{2}{*}{ Comments } \\
\hline & $\stackrel{\Xi}{\underline{E}}$ & 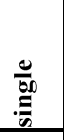 & 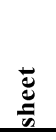 & 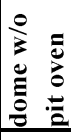 & 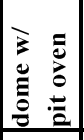 & 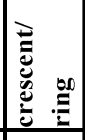 & $\stackrel{n}{=}$ & 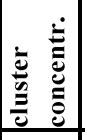 & 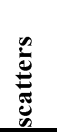 & 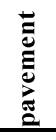 & \\
\hline \begin{tabular}{|l} 
Jetta Court (41TV151) \\
\end{tabular} & $\mathrm{X}$ & & $\mathrm{X}$ & & & & & & & & two middens of diff. time period \\
\hline Greenhaw (41HY29) & $\mathrm{X}$ & & $\mathrm{x}$ & & $\mathrm{X}$ & & & & & & different time periods \\
\hline Crumley (41TV86) & $\mathrm{X}$ & & & $\mathrm{X}$ & & & & & & & \\
\hline \begin{tabular}{|l} 
Loeve Site (41WM133) \\
\end{tabular} & & $\mathrm{X}$ & $\mathrm{X}$ & & & & $\mathrm{X}$ & & & & thin veneer \\
\hline Landslide Site (41BL85) & $\mathrm{X}$ & & $\mathrm{X}$ & & & & $\mathrm{x}$ & $\mathrm{X}$ & & $\mathrm{X}$ & \\
\hline Evoe Terrace (41BL104) & $\mathrm{X}$ & & $\mathrm{X}$ & & & & & & & & \\
\hline Youngsport Site & $\mathrm{X}$ & & $\mathrm{X}$ & & & & & $\mathrm{X}$ & & & \\
\hline $41 \mathrm{BX} 1$ & $\mathrm{X}$ & & $\mathrm{X}$ & & & & & & & & \\
\hline Culebra Creek (41BX126) & $\mathrm{X}$ & & & & $\mathrm{X}$ & & $\mathrm{x}$ & $\mathrm{X}$ & & & \\
\hline Kennedy Bluffs (41BP19) & $\mathrm{X}$ & & $\mathrm{X}$ & & & & $\mathrm{x}$ & $\mathrm{X}$ & & & \\
\hline John Ischy (41WM49) & $\mathrm{X}$ & & & $\mathrm{X}$ & & & & & & & \\
\hline Mustang Branch (41HY209) & $\mathrm{X}$ & & & & $\mathrm{X}$ & & $\mathrm{x}$ & & & & \\
\hline $41 \mathrm{BX} 300$ & $\mathrm{X}$ & & $\mathrm{X}$ & & & & $\mathrm{X}$ & & $\mathrm{X}$ & & \\
\hline Sleeper Site (41BC65) & & $\mathrm{X}$ & $\mathrm{X}$ & & & & $\mathrm{x}$ & $\mathrm{X}$ & & & \\
\hline Camp Pearl Wheat (41KR243) & & $\mathrm{X}$ & $\mathrm{x}$ & & & & $\mathrm{X}$ & $x$ & & & \\
\hline Hop Hill (41GL21) & $\mathrm{X}$ & & $\mathrm{X}$ & & & & $\mathrm{x}$ & $\mathrm{X}$ & & & \\
\hline Jonas Terrace (41ME29) & $\mathrm{X}$ & & $\mathrm{X}$ & $\mathrm{X}$ & & & $\mathrm{X}$ & $\mathrm{X}$ & & & \\
\hline La Jita (41UV21) & $\mathrm{X}$ & & & $\mathrm{X}$ & & & $\mathrm{x}$ & & & & \\
\hline Shep Site (41KE109) & $\mathrm{X}$ & & & $\mathrm{X}$ & $\mathrm{X}$ & & & & & & \\
\hline Wounded Eye Site (41KR107) & $\mathrm{x}$ & & & $\mathrm{x}$ & & & & $\mathrm{X}$ & & & \\
\hline Medio Creek (41BX1421) & $\mathrm{X}$ & & $\mathrm{X}$ & & & & & & & & \\
\hline Bull Penn (41BP19) & $\mathrm{X}$ & & & & & & $x$ & $x$ & & & \\
\hline $41 \mathrm{BT} 6$ & $\mathrm{X}$ & & $\mathrm{X}$ & & & & $\mathrm{x}$ & & & & \\
\hline Cibolo Crossing (41BX377) & $\mathrm{X}$ & & & $\mathrm{X}$ & & & $\mathrm{X}$ & $\mathrm{X}$ & $\mathrm{X}$ & & \\
\hline Woodrow Heard (41UV88) & $\mathrm{X}$ & & $\mathrm{x}$ & & & & $\mathrm{X}$ & $\mathrm{x}$ & $\mathrm{x}$ & & \\
\hline Shoppa Site (41BP191) & $\mathrm{X}$ & & $\mathrm{X}$ & & & & $\mathrm{X}$ & & & $\mathrm{X}$ & \\
\hline \begin{tabular}{|l|} 
Panther Springs Creek (41BX228) \\
\end{tabular} & $\mathrm{X}$ & & $\mathrm{X}$ & $\mathrm{X}$ & & & $\mathrm{X}$ & $\mathrm{X}$ & $\mathrm{X}$ & & \\
\hline Granberg (41BX17) & $\mathrm{X}$ & & & $\mathrm{X}$ & & & & & & & \\
\hline Granberg II (41BX271) & $\mathrm{X}$ & & $\mathrm{X}$ & & & & & & & & \\
\hline Slab Site (41LL78) & $\mathrm{X}$ & & & & & & & $\mathrm{X}$ & & & \\
\hline Wunderlich (31CM3) & $\mathrm{X}$ & & & $x$ & & & & & & & \\
\hline Wilson-Leonard (41WM235) & $\mathrm{X}$ & & $\mathrm{X}$ & & & & & & & & \\
\hline
\end{tabular}


volcanic ash falls and lava flows). However, in certain settings, the more stable the deposition environment (i.e., terraces above active floodplains), the more likely that it will be reoccupied. The more often it is reoccupied the more likely that the living surface will accumulate an increasingly broader range of feature types. While reoccupation episodes may often occur for the procurement or exploitation of the same resource, the economic potential of the region can change over time resulting in changes in site function as well as site use. The latter scenario can produce archeological components containing a broad range of functionally distinct feature types such as hearths and ovens.

If this model is correct, it suggests that living surfaces on stable or slowly aggrading landforms are continually altered during the occupation of a site. New features are created, previously constructed and used features are reused and/or disturbed and a combination of in situ burned rock features, disturbed features, and burned rock discard areas may be present on many living surfaces that are not subject to rapid burial. Sites with a single feature type (i.e., a rock oven) may be the exception and may represent either a unique depositional setting (extremely rapid burial following use), changes in resource structure that resulted in decreased productivity or predictability of resources and discouraged return to the locality, or extremely systematic reuse of a locality for the same functional reason always adding the same feature type to the site furniture.

Within the context of this discussion, we have identified three temporal components in the diagnostic artifact assemblage at 41CM111: an upper potentially late Middle Archaic (Langtry) and two lower stratigraphically undifferentiated Nolan/Pandale and Bell/Early Triangular components. Lacking stratigraphic separation between the two deeper components, it can be argued that the occupation surface was aggrading, but only very slowly over a long period of time. This does not preclude the circumstances that allow for certain features and chipping areas to remain somewhat intact, as is often the case at the Early and Middle Archaic sites reviewed in the preceding discussion. Assuming that the deposits did, in fact, accumulate on relatively stable or very slowly aggrading surfaces, then the period of relative stability suggested by Ricklis and Collins (1994) and Nordt (1992, 1993) may have a strong archeological visibility in this part of Central Texas. The age of the Medina paleosol at the Richard Beene site, for example, fits this stability period precisely (Thoms et al. 1996). The geomorphic circumstances, however, are much different at 41CM111 from the purely alluvial situation at Richard Beene. In the creek valleys west of the Balcones Escarpment, deposits dating ca. $5000 \mathrm{BP}$ occur near the tops of alluvial terraces near the mouths of tributary streams (Lee Nordt, personal communication 2002). Nordt's geoarcheological investigations at $41 \mathrm{CM} 111$ show this surface near the top of the terrace to be blanketed by more recent alluvium, as is often the case in other sites (see Collins et al. 1990; Johnson 1991). However, it was shown earlier (Chapter 8) that the $20-40 \mathrm{~cm}$ thick sheet midden containing the two early Middle Archaic components may have accumulated over no more than 400 years. This of course does not tell us how long the base of this depositional unit may have been exposed before the datable material was introduced onto its surface.

Sheet middens differ from the various forms of dome and crescent/ring middens, and may signal the location of generalized campsites and campsite activities as opposed to more spatially discrete, and perhaps in some instances, more specialized activity sets that created rock ovens. Therefore, like rock ovens, sheet middens are integral components of the site structure. Both sheet middens and rock ovens form on relatively stable surfaces. Since sheet middens occur throughout much of the Holocene in central and southwest Texas, they are not considered an early evolutionary stage leading to the classic Central Texas Late Archaic dome middens with central pits or rock ovens. Dome middens associated with rock ovens are formal structural features at sites where they occur and were formed by repeated use of the oven as a thermal facility (Black and Creel 1998), and are integral components of the overall site structure. People returned to the same place within the site to perform the same activities again and again. On the eastern edge of the Edwards Plateau and Lampasas Cut Plain, dome middens associated with rock ovens formed possibly as early as Early Archaic times (ca. 6000 B.C.) and continue to appear in the archeological record into Late Prehistoric times (Black and Creel 1998). 


\section{Summary and Future Research}

A multicomponent Middle Archaic open campsite, $41 \mathrm{CM} 111$ is situated along a former terrace of the Guadalupe River in the central portion of Comal County. A single burned rock sheet midden comprises the excavated portion of the site. The Middle Archaic affiliation is based on a series of radiometric assays and a corroborative diagnostic projectile point assemblage composed of Early Triangular, Nolan, Pandale, and Bell types, among others. While, the exact area of the midden remains unknown, it is estimated to have covered approximately 900 square meters.

The purpose of this chapter was to review several wellknown archeological sites that possessed a variety of burned rock accumulations. In this review, the proposed terminology was used to illustrate how descriptive form can aid intra- and inter-site comparison. Concomitantly, it has been shown that burned rock sheet middens, such as the one present at 41CM111, occur throughout prehistory and should not be seen as a key feature or diagnostic to any one single temporal component. The principal factors that seem to play a role in the formation of such features include resource structure and geomorphic setting.

The research potential for sheet midden features surpasses that for dome midden deposits such as encountered at Woodrow Heard, Barton, La Jita, Anthon (Goode 2002), and Blue Hole (Mueggenborg 1994). Sheet middens hold the potential of preserving activity areas and site features not found in dome midden deposits lacking central pits. At 41CM111, Feature 3 and three cases of refits are examples of preserved activity sets. Preserved features and activity areas in sheet middens occur at many sites such as Sand Creek and Gypsum Bluff (Shafer 1971) and Higgins Flat (Black et al. 1998), among others. The sheet midden and activity areas were established on relatively stable surfaces and blanketed by alluvial or aeolian sediments soon after they accumulated. Hearth features, chipping areas, and food processing areas have all been preserved in these kinds of sites. While it is difficult to define cultural patterns based the findings at a single buried sheet midden site, it is the accumulated information from numerous such sites from which spatially and chronologically specific patterns are likely to emerge. 


\title{
Chapter 10: Early Middle Archaic Lithic Assemblages
}

\author{
Harry J. Shafer and Steve A. Tomka
}

This chapter discusses three related aspects of early Middle Archaic lithic assemblages. Starting with the lithic assemblage recovered from 41CM111, we discuss the nature of the tool kit and its implications for the interpretation of site use and function. Next, we look at the broader aspects of early Middle Archaic tool kits and what the 41CM111 assemblage, in conjunction with other roughly contemporaneous assemblages, may tell us about technology and adaptation. Finally, we consider the suite of Early Triangular preforms recovered from 41CM111 in the context of other triangular projectile points that characterize the early Middle Archaic, and speculate on what these projectile point technologies may be telling us about hunting technology and hunter-gatherer adaptations and land use.

To identify all potential tools that may form part of an early Middle Archaic tool kit that may have been abandoned at the site, we examined the collection of flaked lithic artifacts and debitage for functional tool forms that might be interpreted as a "tool kit." While we expected to identify formal - heavily retouched - tools within the flaked artifacts we also hoped to identify a suite of expedient tools originally classified as unmodified debitage. Early Triangular points and preforms were the only clearly identifiable functional tools that could be combined into an Early Triangular artifact cluster. One bifacial adze was in the 41CM111 collection, but no exhausted or broken examples were present that might otherwise suggest domestic woodworking tasks. A possible unifacially retouched knife (see Miscellaneous Bifaces in Chapter 7) is the only additional tool that may be part of the Early Triangular tool collection.

Surprisingly, missing from the $41 \mathrm{CM} 111$ assemblage are diagnostic tools generally associated with woodworking and plant processing (Clear Fork and Guadalupe adzes, and oval uniface knives). Clear Fork adzes are regular components in Early Archaic assemblages over much of central and southern Texas (Dial 1998:507-535; Turner and Hester 1999:246), and Guadalupe adzes are frequent items recovered from Early and Middle Archaic assemblages in south-central Texas (Turner and Hester
1999:256). Use-wear studies on Clear Fork tools clearly indicate that these adzes are relatively specialized woodworking tools (Hudler 1997:39) while Guadalupe adzes may have been used as both "percussor cutting tools" and woodworking implements (Brown 1985). Clear Fork tools were recovered from Middle Archaic contexts at Wilson-Leonard (Collins et al. 1998) and Loma Sandia (Taylor and Highley 1995) where they were associated with both male and female burials.

Oval flake knives, including sequent flake unifaces (Decker et al. 2000:268-271) and thin unifaces (Prilliman and Bousman 1998:Figure 17.5), are frequently recovered from Early and Middle Archaic assemblages in central and southwest Texas (Collins et al. 1990:Figure 21c; Johnson 1991:118, 119; Sorrow et al. 1967:Figure 19f). These artifacts are not consistently described as knives, but rather are often referred to as "scrapers" (Word and Douglas 1970:Figure 22) or "side scrapers" (Boldurian and Cotter 1999:41). Use-wear, including organic residue analysis (Shafer and Holloway 1979), has convincingly shown these artifacts to be the blades of "ulu-like" knives hafted in the center of a handle rather than at the end as assumed for most knives (Shafer 1986). Use-wear and organic residue analysis shows their function was primarily plant processing, but as knives they were probably used for other cutting tasks as well, especially in earlier hunting-oriented assemblages of Folsom and Clovis periods (Boldurian and Cotter 1999:41; Frison and Bradley 1980:64-66).

The absence of adzes, gouges, and unifacial knives may indicate that they were never used on site. This interpretation implies a rather narrow range of activities performed at 41CM111 during the early Middle Archaic occupation of the site. However, their absence may also indicate simply that although they could have been used they were not discarded on site. Such a scenario may be expected when site occupation span is shorter than the use-life of formal tools (Schiffer 1975; Shott 1989). That is, the absence of these formal tools may inform us about occupation span since when sites are occupied for short periods, formal tools may simply not have sufficient time to become exhausted and discarded on site prior to 
abandonment. Under these conditions, expedient tool forms that are discarded at the location of use should dominate tool assemblages from short-term campsites. We have mentioned, however, that only one expedient tool was identified in the collection.

The possibility that some tool forms used on site were never discarded there is supported by the recovery of 20 debitage specimens (1.2 percent of typed debitage from N80/E200 and N106/E200) derived from the manufacture and rejuvenation of distally beveled unifacial tool forms. The uniface manufacture and retouch debitage indicates that at least some tool forms manufactured and/or retouched on site were not discarded there prior to abandonment. Nonetheless, what was left at the site might provide clues to site function, technological organization, and regional settlement patterns.

The low number of manos and metates is consistent with the findings at Camp Pearl Wheat (Collins et al. 1990), but is in marked contrast to the Sleeper site, Stratum IIIb at Landslide, and the Middle Archaic component at Wilson-Leonard where both manos and metates were recovered (Johnson 1991:61-76; Sorrow et al. 1967: Table 1; Sullivan 1998:Table 20-4). Assuming no sampling biases, the differences in assemblage content at these five sites may relate to overall functional differences and variability in the relative importance of hunting versus gathering, seasonality, and local environments.

Overall, the inter-assemblage differences mentioned among a number of early Middle Archaic components and the tool forms absent from 41CM111 suggest that the "functional tool kit," if such a thing existed, was not discarded at every site where Early Triangular points were discarded. This observation, while based primarily on the absence of tools, is critical because it recognizes and highlights the variability in early Middle Archaic technological organization and land use. Furthermore, it argues for the presence of a diversified early Middle Archaic land-use strategy that incorporates not only campsites but a range of special activity sites with their own unique tool kits reflective of specific and narrow ranges of activities.

While up to this point we have argued from the perspective of what was missing from the site, we now argue from the perspective of the tools and artifacts that were present on site. The only well-represented tool form from the Early Triangular component consists of projectile points and preforms that were to be made into points. Although a clearly isolable Early Triangular component could not be identified, we can still have confidence in this statement because simply no other tools forms were encountered in the deposits.

Impact fractures on Early Triangular points provide solid evidence for their use as projectile points; and it would stand to reason that the elements comprising the Bell-Early Triangular component may represent a predominantly hunting assemblage. This is not to say that some of these points, with broad blades and long cutting edges, may not have been used as knives (i.e., situational gear) to aid in butchering game when necessary.

As summarized in Chapter 7, the triangular bifaces can be divided into Early Triangular and Bell-Andice projectile points, Early Triangular preforms, and triangular bifaces (i.e., blanks) that may have been intended either as Early Triangular or Bell-Andice points. All of the functional or use-failed points identified at 41CM111 exhibit lateral retouch and signs of moderate to extensive rejuvenation, although perhaps only one (Figure 7-1d) could be classifies as an "exhausted" specimen. Nonetheless, the fact that many of the triangular forms present on site are use-broken or moderately rejuvenated specimens indicates that retooling may have been one of the primary goals of the occupants of the site. This observation is strongly supported by the large number of manufacture-failed (both complete and broken) Early Triangular preforms and triangular bifaces. As a mater of fact, manufacturefailed specimens greatly outnumber use-broken and exhausted forms, the exact pattern one would expect if tools were being manufactured not just for the replacement of failed/exhausted specimens but the restocking of depleted tool kits.

Much of the debitage as well as the projectile points are heavily patinated and it is not possible to identify the color and texture of the original raw material with a great degree of certainty. Therefore, it is not possible to state whether the individuals that occupied the site came from areas outside of central Texas or not. However, the site still offers some insights into regional land-use patterns and strategies. It has been noted earlier that a large 
proportion of the debitage from the site consists of decorticate specimens. In addition, thinning flakes are common in the collection, especially in the deeper, older levels. Chert is not a component of Cordova and Heiser Creek gravel deposits, and while abundant cherts would be found in the Guadalupe River gravel bars, cortex representative of river gravels occurs in combination with upland weathered cortex among the corticated flakes. These debitage patterns, in combination with the late reduction stage (Stages 3 and 4) bifaces and point preforms in the collection, suggest that raw material was obtained at some distance from the site. The evidence suggests that the raw material was reduced to some degree into blanks before it was brought onto the site for further reduction and finishing.

The fact that upland chert sources that match the color and texture of the raw materials from the site are known to occur within five kilometers of the site supports the possibility that site $41 \mathrm{CM} 111$ was a staging area in a land-use strategy and settlement pattern that combined a nearby lithic procurement locality with a short-term, special activity site (41CM111) where the next stage raw material reduction and tool manufacture took place. The fact that the upland chert resource is removed from water, and retooling would likely require a number of days of material procurement and tool manufacture, would explain the need to occupy the 41CM111 locality. The locality provided a flat, stable surface for occupation, was near water, and probably provided access to the basic resources needed to occupy the site for a short time while tool kits were refurbished and restocked.

At first glance, the presence of thermal features generally associated with plant processing appears not to fit the above scenario. One possibility is that the thermal features are the remnants of low-scale food preparation during short-term overnight stays at the locality. The presence of the burned rock sheet midden supports this interpretation in that it signals the lack of site maintenance, a pattern common to hunter-gatherer sites occupied only for short periods. Similarly, the under representation of the traditional food processing technology such as manos and metates also argues for a limited range of foodstuffs and food preparation activities. The relatively large amount of mussel shell recovered from the excavations suggests that mussels, probably obtained from the Guadalupe River, may have been one of the principal food sources consumed at the site. Burned rock thermal features may have been involved in the processing of mussels while the principal activity at the site centered on retooling.

The Bell-Early Triangular functional component is suggestive of lithic retooling but the presence of large numbers of projectile points to the exclusion of other functional classes may also be indicative of the importance of hunting to the site's occupants. The argument that site function points strongly to an almost pure hunting encampment is bolstered by the near absence of tools suggesting other activities. The predominately hunting tool assemblage could indicate the site was primarily used during the seasons when hunting was the prevalent economic activity and plant resources were the least available, such as in the late winter or early spring months. We do not have any information that might relate directly to seasonality, although the frequency of river mussels and snail shells (both presumed food sources) would perhaps suggest a late summer - warm season - occupation. We would not necessarily expect each occupation to occur at the same time of year, but foraging in the immediate vicinity of the site for mussels and snails would not preclude a campsite of mobile hunters.

Now that we have speculated at length regarding the use and function of the site and regional land-use patterns, let us address the final topic of this chapter, the nature of the broad-bladed Early Triangular bifaces and early Middle Archaic hunting technology and technological organization. The association of a Bell point with bison remains in Feature 2 at the Landslide site (Sorrow et al. 1967) is consistent with Johnson's theory that broadbladed point traditions (i.e., Calf Creek and Early Triangular) correlate with the exploitation of bison. Unfortunately, only a small number of animal bones were recovered from 41CM111 and none could confidently be identified as bison. What technological, and therefore adaptive, advantages may be provided by broad-bladed triangular bifaces/points when it comes to bison hunting during the early Middle Archaic?

Blade widths of Early Triangular points are indeed broad in relation to length, but they do not fit Johnson's model for broad-bladed stemmed points associated with bison hunting; but Bell points clearly do (Johnson 1995:286). 
Yet, use or impact wear on Early Triangular specimens from 41CM111 convincingly shows that they were used as both projectile points and knives.

Recent work with the common Middle to Late Archaic south Texas Tortugas points (Mahoney et al. 2002) suggests some important adaptive advantages of triangular point forms. Triangular, stemless forms or basally notched stemmed forms tend to have longer use lives than stemmed points because wider blades allow for higher numbers of resharpening. The manufacture of stemless forms may reduce manufacture failure rates because there is no need for basal notching. Triangular forms may be more resistant to impact failure because they tend to be thickest near the distal end and their thinnest portion is also their widest section, therefore, protecting the point from failing. Finally, based on Tortugas points, when failure does occur it tends to remove only short segments of the point either at the distal or proximal ends, leaving a substantial portion available for rejuvenation.

The triangular projectile point morphology of Early Triangular and Tortugas points share many commonalities including, perhaps, the probable adaptive advantages of the form. The earlier listed characteristics would be particularly advantageous under a high degree of mobility and within the context of bulk resource procurement where long use-life, high point reliability, and ease of maintenance (i.e., rejuvenation/reworking) are at a premium. It is therefore suggested that broadbladed Early Triangular points represent an example of projectile technology that is seemingly well-adapted to land-use and hunting strategies characterized by high mobility and the seasonal bulk procurement of certain resources.

\section{Summary}

The discussion in this chapter focused on three topics identified in the TxDOT scope of work for research conducted at 41CM111. Specifically, we looked at the nature of the 41CM111 early Middle Archaic tool kit and its implications for the interpretation of site use and function. Next, we considered the broader aspects of early Middle Archaic tool kits and what the 41CM111 assemblage in conjunction with other roughly contemporaneous assemblages may tell us about technology and adaptation. Finally, we discussed early Middle Archaic triangular projectile points and speculated about what they may tell us about hunting technology and hunter-gatherer adaptations and land use.

Although the early Middle Archaic tool assemblage recovered from $41 \mathrm{CM} 111$ is very poor in functional terms, both the artifact classes that are missing from the site (versus other sites from the same time period) as well as the artifact classes present, provide an interesting picture of site use and function. While no functional tool kit could be identified, the Early Triangular component at the site appears to represent a narrow range of activities primarily oriented toward tool manufacture and retooling. The limited number of functional types argues for repeated short-term reoccupations of the site with food procurement apparently focused on riverine resources.

The location of the site, the range of available nearby resources, and the lithic collection all suggest that 41CM111 may have functioned as a staging area where lithic blanks, initially reduced at the procurement site, would be further reduced and made into finished products. The retooling or restocking of the lithic tool kits would suggest some involvement in bulk procurement strategies.

Finally, we suggested, based on research focused on Tortugas points, that Early Triangular projectile points may have numerous and significant adaptive advantages to highly mobile hunter-gatherers. Included among these are the increased use-life of the points, high projectile point reliability, and ease of maintainability. 


\title{
Chapter 11: $\quad$ Summary and Conclusions
}

\author{
Steve A. Tomka, Richard B. Mahoney, and Harry J. Shafer
}

In 2002, the Center for Archaeological Research carried out limited excavations at 41CM111, the Royal Coachman site, as part of a geomorphological assessment of the site. The site is located along Farm to Market (FM) 306 near the eastern crossing of the Guadalupe River in Comal County. The roadway bisects the site into northern and southern halves. Archeologists from TxDOT originally excavated the site in 1980 , to mitigate the impacts of planned road widening.

The CAR excavations followed the assessment of the materials recovered and documentation produced during the 1980 fieldwork. The principal goals of the additional fieldwork were to assess the geomorphological context of the site and deposits, obtain additional datable samples, and identify additional features.

The original TxDOT fieldwork resulted in the excavation of a total of $50.34 \mathrm{~m}^{3}$ of matrix, much of it coming from a block excavation from the northern half of the site. In 2002, CAR hand-excavated an additional $3.5 \mathrm{~m}^{3}$ of matrix from the southern half of the site and also excavated five backhoe trenches for geomorphic purposes.

Geomorphic assessment of the locality and site indicates that the Holocene alluvial stratigraphy in the project area is subdivided into an early Holocene unit $(\mathrm{EH})$ and a late Holocene unit ( $\mathrm{LH})$. The deposition of the EH unit began and proceeded to no later than $4300 \mathrm{BP}$. A period of channel erosion ensued shortly after $4300 \mathrm{BP}$ as both the Guadalupe River and Cordova Creek downcut into bedrock, transforming the EH surface into a terrace or flood terrace. Deposition of the LH alluvium began with flood deposits partially burying the EH unit. Flood magnitudes appear to have increased in the late Holocene because the LH channel deposits contain an abundance of coarse cobbles with little over-bank deposition.

The stratigraphic and chronological assessment of the deposits and seven radiocarbon assays indicate that at least three components are present at the site. The upper component or depositional unit is encountered between $30-50 \mathrm{cmbs}$ and is manifested as a peak in mussel shell and unmodified debitage. Although this component was not dated with radiocarbon assays, a single Langtry point suggests that it may date to the late Middle Archaic. The deeper archeological components contain Nolan/Pandale and Andice-Bell/Early Triangular projectile points. The lower depositional zone extends from roughly $70-100 \mathrm{cmbs}$ and is dated to between 5880-5320 BP (2-sigma date ranges). Although a slight hint of separation exists between the diagnostics from the two deepest components, they cannot be reliably separated. The distribution of the artifacts suggests that there may be some horizontal variability in the degree to which the uppermost and the two deeper components are manifested across the site (i.e., north and south of FM 306).

Seven features were identified on site. The principal feature, most clearly evident in the TxDOT excavations, is a sheet midden composed of burned rocks. Although no analyses were conducted to indicate that much of the burned rock within this sheet midden was disturbed from its original location, only one in situ feature (Feature 3) could be identified based on the patterned clustering of burned rock. A second partially disturbed feature (Feature 7) was encountered on the southern portion of the site in one of the CAR excavation units.

The artifact collection recovered from the site, and in particular the temporally diagnostic projectile points in conjunction with vertical patterning in artifact distributions, helped identify the three components present at the site. Artifactually, the most well-represented component consists of Early Triangular projectile points and preforms. On-site tool reduction activities may have begun from prepared blanks brought to the site from nearby lithic source areas. The overall scarcity of tool forms other than projectile points suggests that one of the principal functions of the site within the regional landuse strategy was tool manufacture and retooling. This type of retooling may have involved overnight stays, and this short-term site use probably included limited food procurement such as the gathering of mussels from the nearby Guadalupe River. 
Prior to the initiation of the current project, TxDOT archeologists had indicated that one of the principal reasons for conducting additional work at 41CM111 was to better define the geomorphological setting of the site. Two additional topics were proposed to direct and focus the analysis of the materials from 41CM111 and interpret the early Middle Archaic component present at the site. The first focused on the nature and role of burned rock accumulations as food preparation furniture. Do these features have Early Archaic or early Middle Archaic precursors and how do they relate to later burned rock features in form and function? What do they tell us about site formation processes and occupation history? At a minimum, four archeological sites with early Middle Archaic components and within Bexar County were to be consulted (i.e., 41BX126, 41BX228, 41BX300, and 41BX1421); however, a more comprehensive review of sites was deemed necessary to document diachronic patterns in burned rock feature use and variability in burned rock feature morphology. The second topic focused on investigating little-known aspects of early Middle Archaic lithic assemblages such as the function and use of Early Triangular bifaces, and the overall make-up of the lithic tool kit of early Middle Archaic hunter-gatherers.

Establishing whether certain types of burned rock accumulations are diagnostic of early Middle Archaic adaptations presents not only theoretical but also methodological challenges. For instance, one of the critical issues is to define whether the burned rock features represent in situ thermal facilities or are accumulations derived from secondary discard. While the quantities of fire-cracked rock are considerable in many of these accumulations, in many cases clusters of burned rock - that can be defined as rock-lined hearthscan be discerned within them. In addition, some strides have been made in identifying the heating temperatures achieved in some burned rock features as well as the post-depositional rearrangement of rocks (Collins et al. 1990). Often the use and occupation history of sites with burned rock features is inadequately documented. Few early Middle Archaic components have been sufficiently well-dated to know whether the few hearths that may be discerned within the burned rock accumulations represent contemporaneous uses of the surface or palimpsest reoccupations of a surface separated by decades or even centuries. Similarly, few excavations have been carried out at a sufficiently large scale to identify the structure of activities associated with these accumulations and/or thermal facilities on a prehistoric site. We do not know if the accumulations represent discard areas on the periphery of carefully maintained activity areas, or are the primary activity areas themselves. Finally, although some promising methodological strides have been made recently (i.e., residue analysis), little direct evidence is available regarding the foodstuffs processed within these features and the season and/or seasons of occupation of sites containing these features.

Regardless of these methodological challenges, the archeological data that has accumulated over decades of research in the state does allow us to define some preliminary patterns that can serve as future research directions. In Chapter 9, we summarized data from 32 Early Archaic and Middle Archaic sites that contain evidence of burned rock thermal facilities. The summary included selected components from several sites located within the Central Texas Archeological Region.

It is clear from archeological components dating to the Early Archaic (e.g., Camp Pearl Wheat, Collins et al. 1990; the Sleeper site, Johnson 1991; Wilson-Leonard, Collins et al. 1998) that the use of rock-lined thermal features predates the principal use of 41CM111 (the early Middle Archaic represented by the Early Triangular specimens). Our review suggests that thermal features utilizing heated rock most likely came into existence during Paleoindian times and saw a minor explosion in use during the Early Archaic/early Middle Archaic period. A variety of burned rock feature types are present in components dating to this time period. Furthermore, the review indicates that burned rock sheet middens, such as the one present at 41CM111, occur throughout prehistory and should not be seen as a key feature or diagnostic to any one single temporal component. Perhaps more importantly, however, variability in burned rock features and their use through space and time appears to be more informative in terms of such broad aspects of hunter-gatherer adaptation as resource structure, landuse strategies, site reuse, and geomorphic context.

The Early Archaic period, the transition from highly mobile hunter-gatherers pursuing megafauna to mixedeconomy groups pursuing medium to small game and relying on plant resources to a greater extent than before, 
occurs relatively early in Central Texas (i.e., 8800 BP; Collins 1995:376) and lasts for some 2,800 years (i.e., $6000 \mathrm{BP}$ ). The transition from late Paleoindian to Archaic lifeways not only represented a change in subsistence practices and food processing, but also hunting technology. The shift from lanceolate to stemmed points is a pattern that seems to occur continent-wide and is not yet adequately understood. On the other hand, the appearance of unstemmed triangular projectile points that may have regularly been used as knives during the Early Archaic or early Middle Archaic (i.e., Early Triangular [also, Taylor, Baird]), and the perseverance of the form through time (i.e., Tortugas and Matamoros) in certain parts of the state also represents an interesting explanatory challenge. Mahoney et al. (2002) have recently suggested that the multifunctional triangular form is extremely well suited under high mobility and in settings where there is little congruence between the distribution of edible and lithic resources. A detailed study of Matamoros and Tortugas points from South Texas suggests that the triangular morphology may provide some technological advantages (e.g., lower failure rates, higher reliability) over notched and/or stemmed points (Tomka 2002). Nonetheless, to document and test the differential reliability and maintainability of distinct projectile point forms, a comprehensive study of Paleoindian and Archaic point forms is proposed as a future research issue.

While changes in projectile point technology are reasonably well-documented in the state, much less is known about the overall make-up of Early Archaic and early Middle Archaic lithic technology. For instance, little is known of the non-projectile point tools of the Early Archaic tool kits. Some components have provided limited information on Early Archaic assemblages (i.e., Sleeper site, Panther Spring Creek site), suggesting that woodworking was one of the principal activities. However, archeologists have not yet investigated sufficient numbers and varieties of Early Archaic and early Middle Archaic components and assemblages to define the make-up of these tool kits.

Unfortunately, the very small non-projectile point assemblage from 41CM111 and the admixture of at least two components in the deepest levels of the site did not allow a comprehensive discussion of early Middle Archaic tool kits. Nonetheless, the absence of many tool forms, and their presence at other Early Archaic and early Middle Archaic sites, indicates that there may exist a considerable degree of variability in use and function among sites dating to these time periods. This is a critical observation since it implies significant variability in assemblage content and functional variability between sites. It also highlights the fact that lacking such temporal diagnostics and charcoal for radiocarbon dating, one would be hard pressed to assign such components to their correct temporal affiliation.

Although the Royal Coachman site investigations did not produce a "typical" Early Archaic or early Middle Archaic lithic assemblage, the recovery of a moderate Early Triangular projectile point/preform collection is noteworthy. In combination with the consistent dates derived from five of the six radiocarbon assays on wood charcoal from the site, 41CM111 produced one of the more securely dated Early Triangular components in the state. Five of the six radiocarbon assays from wood charcoal returned 1-sigma dates ranging from $5600-5460$ BP. This date range falls closest to that proposed by Turner and Hester (1999:108) for Early Triangular points.

The proveniences from 41CM111 that contained Early Triangular projectile points also contained point types that both pre-dated (i.e., Andice, Bell) as well as postdated (Nolan, Pandale) the triangular forms. This admixture of temporal diagnostic artifacts may have broad implications related to the preservation and distribution of Early Archaic and early Middle Archaic components on the southern and eastern margins of the Edwards Plateau.

Although a buried paleosol was not conclusively identified at the site, the geomorphological results in combination with the radiocarbon assays allow the calculation of a general aggradation rate for the site's deposits. The calculations suggest that the archeological deposits of 41CM111 may have built up over a period of 400 years. Even if this estimate is correct, the deposits could have built up very gradually over the period or they may have built up very rapidly over a short period of time within this 400-year window. The range of temporally diagnostic point types found together within a $20-40 \mathrm{~cm}$ thick zone suggests slow rates of aggradation. The possibility that the 41CM111 deposits built up on a stable or slowly aggrading surface is supported by 
regional geomorphological trends. The likelihood that this is a period of relative geomorphological stability is supported by data from surrounding regions.

A buried paleosol indicating a stable surface dating approximately 5000 BP is widely documented across central and west-central Texas (Collins 1995:Table 2; Nordt 1992; 1993; Pearl et al. 2003). Alluvial histories along the Sabinal, possibly Medina, Lampasas, and Ft. Hood rivers, as well as the Colorado and Concho confluence, and Brazos River at South Bend provide evidence for this interpretation. This interruption in alluvial accumulation occurred at a time when the climate was warmer and drier, and when $\mathrm{C} 3$ plants had become well established across Central Texas. The previous moist regimes had given way to drier grasslands and parklands and bison were present in Central Texas at least during parts of this interval (Sorrow et al. 1967). This stable surface cycle also correlates with the time when Middle Archaic Bell/Andice and Early Triangular point types were produced.

It is likely that this drier cycle resulted in substantial changes in the composition and distribution of plant and animal communities and resources. Unfortunately, we do not yet understand in detail the influence of climatic conditions on plant and animal communities. Nonetheless, it is safe to assume that drier conditions may have favored the development of grasslands and scrublands to the expense of woodlands that may have been restricted to the moister valley bottoms. Drier climatic conditions may have also resulted in the geographic expansion of marginal Chihuahuan Desert plants such as sotol. In turn, the development of C3 grasses may have affected bison, antelope, and deer ranges, and the ebb and flow of these prey species through time most certainly affected subsistence and settlement strategies across the region. These changes in resource distribution coupled with changes in stream flow regimes and water availability also have dramatic effects on regional land-use strategies as suggested by McKinney (1981) and Tomka et al. (1997) and manifested by the concentration of sites along the margins of the Edwards Plateau.

If portions of the Early Archaic and early Middle Archaic periods are characterized by slow rates of deposition and a tendency for the admixture of otherwise temporally distinct materials, are there specific settings where these components may be encountered stacked and separated by sterile deposits? Given the results of our findings at 41CM111, archeological deposits dating to the middle Holocene that have the most potential for intact deposits are primarily stream terraces. Nordt $(1992,1993)$ has identified and dated such terrace deposits in the Fort Hood area. T1 of Cowhouse Creek, for example, contains alluvial deposits that date to this period of time (50006000 BP). Along the Lampasas River, Pearl et al. (2003) have identified intact archeological deposits buried in T2; such notable sites as Youngsport (Shafer 1963) and Landslide (Sorrow et al. 1967) are buried in T2 deposits. Moving southward, Merrill (Campbell 1948) and Wilson-Leonard (Collins et al. 1998) are sites buried in equivalent Holocene alluvial formations along Brushy Creek. Perhaps one of the better examples of rapid alluvial buildup during the middle Holocene is documented along the Medina River in the Applewhite Reservoir basin (Thoms et al. 1996). Overall, alluvial terraces dating to the early and middle Holocene provide the most promising locations for Early and Middle Archaic sites. Surface stability partially depends on the location of the site with regards to topography of the surrounding landscape. A stable surface situation such as is documented at the Woodrow Heard site (Decker et al. 2000), on which some 5,000 years of human occupation was stacked, was much different from that at $41 \mathrm{CM} 111$ where the Middle Archaic occupation sequence was probably interrupted by changing local conditions that may have provided a more favorable locality for occupation in later times as Nordt suggests (see Chapter 6). This fortunate occurrence left the Middle Archaic components at 41CM111 more or less isolated.

Rockshelter deposits are less promising in yielding early and middle Holocene cultural material for two reasons: first, few intact rockshelter sites remain in Central Texas; and second, rockshelter deposits are often accumulated refuse midden deposits and usually lack good vertical separation within these deposits, as was the case at Oblate Rockshelter (Johnson et al. 1962). Deeply stratified rockshelter deposits, such as was encountered in the lower Pecos River region at Arenosa Shelter (Dibble 1967) and Hinds Cave (Shafer and Bryant 1977), are not duplicated in Central Texas. The caveat is that rockshelters in Central Texas were often occupied for only specific periods of time and do yield critical information 
(Jelks 1962; Suhm 1957). The opportunity to investigate a rockshelter should never be passed up; after all, these were once used as residential structures and the opportunity to investigate the actual site of a known residential structure is an extremely rare circumstance in Central Texas archeology.

If due to large-scale climatic conditions and specific geomorphological context, Early Archaic and early Middle Archaic components rarely occur in isolated, unmixed contexts, why should archeological research continue to focus on such sites? If site 41CM111 is typical of mixed component sites dating to the Early and early Middle Archaic, it is also typical of the research potential of such sites. For instance, although as many as three components may be present at the site, data from the Early Triangular points and preforms allowed us to clearly document approaches to raw material procurement and projectile point manufacture and use at the site. In addition, the contrast between the Early Triangular projectile point-preform collection and the Andice/Bell and Nolan/Pandale projectile point assemblages from the site serves as a very dramatic illustration of differences in site use and function between the three components. Specifically, while retooling was one of the key aspects of site use when Early Triangular points were manufactured, the refurbishing of the projectile points did not seem to be a prime concern at other times. Overall, then, while the site may have mixed deposits, certain specific data types (i.e., projectile points, charcoal for radiocarbon assays) can make significant contributions to research. And, finally, it is based exactly on the mixed nature of the components coupled with the geomorphological reconstruction that emerged from the site that we are able to suggest that the pattern noted at 41CM111 may be related to paleoclimatic conditions. And, it is through the definition of the components that we can gauge the variability in land-use strategies over time as we observe both the components that are present as well as those absent from a particular setting.

It is the recommendation of CAR that site 41CM111 warrants designation as a State Archeological Landmark and is eligible for listing on the National Register of Historic Places because of the significance of its data that contributes to a better understanding of the regional archeological record. We believe that these investigations have resulted in an appropriate level of work to evaluate the archeological property within the highway ROW and no further work is currently recommended. We also recommend that TxDOT consider avoidance as an option during future construction activities to avert impact to remaining deposits. In addition, if new ROW is acquired, additional work is warranted to determine the extent and significance of currently unidentified material. This report presents the findings of site investigations and completes the reporting responsibilities of CAR and TxDOT under Texas Antiquities Committee Permit No. 2807. 



\section{References Cited}

Andrefsky, W., Jr.

1998 Lithics Macroscopic Approaches to Analysis. Cambridge University Press. Cambridge.

Arnn, J. W., III

1997a Archaeological Investigations at the Landa Park Golf Course, New Braunfels, Texas. Archaeological Survey Report, No. 250. Center for Archaeological Research, The University of Texas at San Antonio.

1997b Archaeological Monitoring of a Sidewalk Construction Project in Landa Park, New Braunfels, Texas. Archaeological Survey Report, No. 254. Center for Archaeological Research, The University of Texas at San Antonio.

1997c Archaeological Investigations at the Landa Park Golf Course Pro Shop, New Braunfels, Texas. Archaeological Survey Report, No. 256. Center for Archaeological Research, The University of Texas at San Antonio.

Assad, C. A.

1979 Archaeological Testing in the Devine Road Area North of Olmos Dam, San Antonio, Texas. Archaeological Survey Report, No. 53. Center for Archaeological Research, The University of Texas at San Antonio.

Bailey, G. L., and C. B. Bousman

1989 Subsurface Archaeological Survey and Monitoring of the Landa Street/Fredericksburg Road Drainage Improvement Project, Comal County, Texas. Technical Reports Number 6. Prewitt and Associates, Inc., Austin.

Barnes, V. E. (editor)

1982 Geologic Atlas of Texas: San Antonio Sheet. Bureau of Economic Geology, The University of Texas Austin.

Batte, C. D.

1984 Soil Survey of Comal and Hays Counties, Texas. United States Department of Agriculture, Soil Conservation Service. Washington, D.C.

Bement, L. C.

1984 Intensive Investigations of $41 B P 191$ and 41BP192, The Powell Bend Prospect, Bastrop County, Texas. Research Report No. 87. Texas Archeological Survey, The University of Texas at Austin.

1989 Excavations at 41BP19, The Kennedy Bluffs Site, Bastrop County, Texas. Contract Reports in Archaeology, Report Number 5. State Department of Highways and Public Transportation, Austin.

Black, S. L.

1989 South Texas Plain. In From the Gulf Coast to the Rio Grande: Human Adaptation in the Central, South, and Lower Pecos Texas, by T. R. Hester, S. L. Black, D. G. Steele, B. W. Olive, A. A. Fox, K. J. Reinhard, and L. C. Bement, pp. 39-62. Research Series No. 33. Arkansas Archeological Survey, Fayetteville.

Black, S. L., and D. G. Creel

1998 The Central Texas Burned Rock Midden Reconsidered. In Hot Rock Cooking on the Edwards Plateau: Four Burned Rock Midden Sites in West Central Texas, by S. L. Black, L. W. Ellis, D. G. Creel, and G. T. Goode, pp. 269-305. Studies in Archeology 22. Texas Archeological Research Laboratory, The University of Texas at Austin. Archeology Studies Program, Report 2. Environmental Affairs Division, Texas Department of Transportation, Austin. 
Black, S. L., and A. J. McGraw

1985 The Panther Springs Creek Site: Cultural Change and Continuity within the Upper Salado Creek Watershed, South-Central Texas. Archaeological Survey Report, No. 100. Center for Archaeological Research, The University of Texas at San Antonio.

Black, S. L., L. W. Ellis, D. G. Creel, and G. T. Goode

1997 Hot Rock Cooking on the Edwards Plateau: Four Burned Rock Midden Sites in West Central Texas. Studies in Archeology 22. Texas Archeological Research Laboratory, The University of Texas at Austin. Archeology Studies Program, Report 2. Environmental Affairs Division, Texas Department of Transportation, Austin.

Black, S. L., K. Jolly, C. D. Frederick, J. R. Lucas, J. W. Karbula, P. R. Takac, and D. R. Potter 1998 Archeology along the Wurzbach Parkway. Module 3. Investigations and Experimentation at the Higgins Site (41BX184). Volume 1 and 2. Studies in Archeology 27. Texas Archeological Research Laboratory, The University of Texas at Austin.

Blair, W. F. 1950 The Biotic Provinces of Texas. Texas Journal Science 2(1):93-113.

Blum, M. D., and S. Valastro

1989 Response of the Pedernales River of Central Texas to Late Holocene Climate Change. Annals of the Association of American Geographers 79:435-456.

1994 Late Quaternary Sedimentation, Lower Colorado River, Gulf Coastal Plain of Texas. Geological Society of America Bulletin 106:1002-1016.

Boldurian, A. T., and J. L. Cotter

1999 Clovis Revisited: New Perspectives on Paleoindian Adaptations from Blackwater Draw, New Mexico. The University Museum, University of Pennsylvania, Philadelphia.

Bousman, C. B.

1992 Preliminary Oxygen-Isotope Evidence for Late Pleistocene-Early Holocene Climatic Change. Current Research in the Pleistocene 9:78-80.

1994 The Central Texas Pollen Record: A Reinterpretation. Current Research in the Pleistocene 11:79-81.

1998 Paleoenvironmental Change in Central Texas: The Palynological Evidence. Plains Anthropologist (43)164:201-219.

Bradley, B. A.

1975 Lithic Reduction Sequences: A Glossary and Discussion. In Lithic Technology, Making and Using Stone Tools, edited by E. Swanson, pp. 5-13. Mouton Publishers, The Hague.

Brown, K. M.

1985 Three Caches of Guadalupe Tools from South Texas. Bulletin of the Texas Archeological Society 56:75-125.

Brune, G.

1975 Major and Historic Springs of Texas. Report No. 189. Texas Water Development Board, Austin.

Bryant, V. M., Jr.

1977 A 16,000 Year Pollen Record of Vegetation change in Central Texas. Palynology 1:143-155. 
Bureau of Economic Geology

1983 The Geologic Atlas of Texas, San Antonio Sheet. The University of Texas at Austin.

Buskirk, W.

1986 The Western Apache: Living with the Land before 1950. University of Oklahoma Press, Norman.

Camper, H. A.

1991 Pollen Analysis of Patschke Bog. Unpublished MS thesis, Department of Botany, Texas A\&M University, Bryan, Texas. Data archived at the World Data Center-A for Paleoclimatology Data. NOAA/NGDC Paleoclimatology Program, Boulder, Colorado.

Chandler, C. K., and L. Lopez

1992 A Quarry Site in Western Duval County. La Tierra 19(2):12-13.

Clabaugh, P. A.

1994 The Nature and Distribution of Features. In The Valley Branch Archaeological Project: Excavations at an Archaic Site (41MU55) in the Cross Timbers Uplands, North-Central Texas, edited by A. V. Thoms, pp. 81-110. Reports of Investigations No. 15. Archaeological Research Laboratory, Texas A\&M University, College Station.

Clark, J. E.

1991 Modern Lacandon Lithic Technology and Blade Workshops. In Maya Stone Tools: Selected Papers from the Second Maya Lithic Conference, edited by T. R. Hester and H. J. Shafer, pp. 251-269. Prehistory Press, Madison, Wisconsin.

Collins, M. B.

1994 Thoughts on Future Investigations of Burned Rock Middens. In The Burned Rock Middens of Texas: An Archeological Symposium, edited by T. R. Hester, pp. 1-24. Studies in Archeology 13. Texas Archeological Research Laboratory, The University of Texas at Austin.

1995 Forty Years of Archeology in Central Texas. Bulletin of the Texas Archeological Society 66:361-400.

Collins, M. B., B. Ellis, and C. Dodt-Ellis

1990 Excavations at the Camp Pearl Wheat Site (41KR243): An Early Archaic Campsite on Town Creek, Kerr County, Texas. Studies in Archeology No. 6. Texas Archeological Research Laboratory, The University of Texas at Austin.

Collins, M. B., J. Guy, and S. W. Dial

1998 The Archaic Period, 8800 to 1300 BP. In Wilson-Leonard, An 11,000-year Archeological Record of HunterGatherers in Central Texas, edited by M. B. Collins, pp. 211-270. Studies in Archeology 31. Texas Archeological Research Laboratory, The University of Texas at Austin. Archeology Studies Program, Report 10. Environmental Affairs Division, Texas Department of Transportation.

Corps of Engineers (COE), U.S. Army

1933 Hunter, Texas Tactical Map. Special Edition 2509:3750/99, Grid Zone “D”.

Crabtree, D. E.

1972 An Introduction to Flintworking. Occasional Papers of the Idaho State Museum 28. Pocatello. 
Creel, D., A. J. McGraw, F. Valdez, and T. C. Kelly

1979 Excavations at 41LK106, A Prehistoric Occupation Site in Live Oak County, Texas. Archaeological Survey Report, Number 62. Center for Archaeological Research, The University of Texas at San Antonio.

Creel, D., R. F. Scott, IV, and M. B. Collins

1990 A Faunal Record From West Central Texas and its Bearing on Late Holocene Bison Population Changes in the Southern Plains. Plains Anthropologist 35:55-69.

Davis, G., D. Fox, C. Jurgens, D. Prikryl, and H. Whitsett

1997 Texas Water Development Board 1996 Annual Report to the Texas Historical Commission for Texas Antiquities Permit 1641. Texas Water Development Board, Austin.

Decker, S., S. L. Black, and T Gustavson

2000 The Woodrow Heard Site, 41UV88: A Holocene Terrace Site in the Western Balcones Canyonlands of Southwestern Texas. Studies in Archeology 33. Texas Archeological Research Laboratory, The University of Texas at Austin. Archeology Studies Program, Report 14. Environmental Affairs Division, Texas Department of Transportation, Austin.

Dial, S. W.

1998 Clear Fork Tools. In Wilson-Leonard, An 11,000-year Archeological Record of Hunter-Gatherers in Central Texas, Volume II: Chipped Stone Artifacts, edited by M. B. Collins, pp. 507-535. Studies in Archeology 31. Texas Archeological Research Laboratory, The University of Texas at Austin. Archeology Studies Program, Report 10. Environmental Affairs Division, Texas Department of Transportation.

Dibble, D. S.

1967 Excavations at Arenosa Shelter, 1965-66. Texas Archeological Salvage Project. The University of Texas at Austin. Submitted to the National Park Service.

Dillehay, T. D.

1974 Late Quaternary Bison Population Changes on the Southern Plains. Plains Anthropologist 19(65):180-196.

Ensor, H. B., and C. S. Mueller-Wille

1988 Excavations at the Bull Pen Site 41BP280, Colorado River Drainage, Bastrop County, Texas. Contract Reports in Archaeology, Report Number 3. Texas State Department of Highways and Public Transportation, Highway Design Division, Austin.

Flannery, K. V.

1968 Archeological Systems Theory and Early Mesoamerica. In Anthropological Archeology in the Americas, edited by B. J. Meggers, pp. 67-87. Anthropological Society of Washington. Washington, D.C.

Fredlund, G.

1994 The Phytolith Record at the Wilson-Leonard Site. Program and Abstracts, 52nd Plains Conference, 65th Annual Meeting of the Texas Archaeological Society. Lubbock.

1998 Phytolith Analysis. In Wilson-Leonard, An 11,000-year Archeological Record of Hunter-Gatherers in Central Texas, Volume V: Special Studies, edited by M. B. Collins, pp. 1637-1651. Studies in Archeology 31. Texas Archeological Research Laboratory, The University of Texas at Austin. Archeology Studies Program, Report 10. Environmental Affairs Division, Texas Department of Transportation, Austin. 
Fredlund, G. G., C. B. Bousman, and D. K. Boyd

1998 The Holocene Phytolith Record from Morgan Playa in the Rolling Plains of Texas. Plains Anthropologist (43)164:187-200.

Frison, G. C., and B. A. Bradley

1980 Folsom Tools and Technology at the Hanson Site, Wyoming. University of New Mexico Press, Albuquerque.

Goode, G. T.

2002 The Anthon Site: A Prehistoric Encampment in Southern Uvalde County, Texas. Archeological Studies Program Report 38. Texas Department of Transportation, Environmental Affairs Division, Austin.

Graham, A., and C. Heimsch

1960 Pollen Studies of Some Texas Peat Deposits. Ecology 41:751-763.

Graham, R. W.

1976 Friesenhahn Cave Revisited (A Glimpse of Central Texas 20,000 Years Ago). The Mustang 18(5):1-7.

Gunn, J., and R. Mahula

1977 Hop Hill: Culture and Climatic Change in Central Texas. Special Report, No. 5. Center for Archaeological Research, The University of Texas at San Antonio.

Hall, S. A., and S. Valastro, Jr.

1995 Grassland Vegetation in the Southern Great Plains during the Last Glacial Maximum. Quaternary Research 44:237-245.

Hester, T. R.

1971 Archeological Investigations at the La Jita Site, Uvalde County, Texas. Bulletin of the Texas Archeological Society 42:51-148.

1995 The Prehistory of South Texas. Bulletin of the Texas Archeological Society 66:427-459.

Hester, T. R., and H. Kohnitz

1975 Chronological Placement of "Guadalupe" Tools. La Tierra 2(2):22-25.

Hofman, J. L.

1992 Putting the Pieces Together: An Introduction to Refitting. In Piecing Together the Past: Applications of Refitting Studies in Archaeology, BAR International Series 578:1-20.

Holloway, R. G., and V. M. Bryant, Jr.

1984 Picea glauca Pollen from Late Glacial Deposits in Central Texas. Palynology 8:21-32.

Hudler, D. B.

1997 Determining Clear Fork Tool Function Through Use-Wear Analysis: A Discussion of Use-Wear Methods and Clear Fork Tools. Studies in Archeology 25. Texas Archeological Research Laboratory, The University of Texas at Austin. 
Humphrey, J. D., and C. R. Ferring

1994 Stable Isotopic Evidence for Latest Pleistocene and Holocene Climatic Change in North-Central Texas. Quaternary Research 41:200-213.

Hurt, R. D.

1980 Archeological Investigations of Portions of the Middle Concho Valley. Unpublished Masters Thesis, Texas Tech University, Lubbock.

Jelks, E. B.

1962 The Kyle Site. A Stratified Central Texas Aspect Site in Hill County, Texas. Archaeology Series 5. Department of Anthropology, The University of Texas at Austin.

Johnson, L., Jr.

1962 Wunderlich: A Burned-Rock Midden Site. In Salvage Archeology of Canyon Reservoir: The Wunderlich, Footbridge, and Oblate Sites. Texas Memorial Museum, Bulletin No. 5.

1989 Great Plains Interlopers in the Eastern Woodlands during Late Paleo-Indian Times: The Evidence from Oklahoma, Texas, and Areas Close By. Office of the State Archeologist Report 36, Texas Historical Commission, Austin.

1991 Early Archaic Life at the Sleeper Archaeological Site, 41BC65, of the Texas Hill Country, Blanco County, Texas. Publications in Archaeology, Report 39. Texas Department of Transportation, Austin.

1995 Past Cultures and Climates at Jonas Terrace, 41ME29, Medina County, Texas. Office of the State Archeologist Report 40. Texas Historical Commission, Austin.

1997 The Lion Creek Site (41BT105) Aboriginal Houses and Other Remains at a Prehistoric Rancheria in the Texas Hill Country (Burnet County). Archeology Studies Program, Report No. 1. Environmental Affairs Division, Texas Department of Transportation, Austin. Report 41. Office of the Sate Archaeologist, Texas Historical Commission, Austin.

Johnson, L., Jr., and G. T. Goode

1994 A New Try at Dating and Characterizing Holocene Climates, as Well as Archeological Periods, on the Eastern Edwards Plateau. Bulletin of the Texas Archeological Society 65:1-51.

Johnson, L., D. A. Suhm, and C. D. Tunnell

1962 Salvage Archeology of Canyon Reservoir: The Wunderlich, Footbridge, and Oblate Sites. Texas Memorial Museum, Bulletin No. 5.

Katz, P. R.

1987 Archaeological Mitigation at 41BX300, Salado Creek Watershed, South-Central Texas. Archaeological Survey Report, Number 130. Center for Archaeological Research, The University of Texas at San Antonio.

Kelley, J. C.

1947 The Cultural Affiliations and Chronological Position of the Clear Fork Focus. American Antiquity 13:97-109.

Kelly, T. C.

1961 The Crumley Site: A Stratified Burnt Rock Midden, Travis County, Texas. Bulletin of the Texas Archeological Society 31:239-272. 
Kibler, K. W., and A. M. Scott

2000 Archaic Hunters and Gatherers of the Balcones Canyonlands: Data Recovery at the Cibolo Crossing Site (41BX377), Camp Bullis Military Reservation, Bexar County, Texas. Reports of Investigations, Number 126. Prewitt \& Associates, Inc., Austin.

Kleinbach, K., G. Mehalchik, J. T. Abbott, and J. M. Quigg

1995 Other Analyses. In NRHP Significance Testing of 57 Prehistoric Archeological Sites on Fort Hood, Texas, Volume II, edited by J. T. Abbott and W. N. Trierweiler, pp. 765-801. United States Army Fort Hood Archeological Resource Management Series Research Report No. 34.

Larson, D. A., V. M. Bryant, and T. S. Patty

1972 Pollen Analysis of a Central Texas Bog. The American Midland Naturalist 88:358-367.

Luke, C. J

1974 Archaeological Investigations along the Route of U.S. 281 from Mulberry Avenue to Tuxedo Avenue, San Antonio, Texas. State Department of Highways and Public Transportation. On file at the Center for Archaeological Research, The University of Texas San Antonio.

1980 Continuing Archeology on State Highway 16: The Shep Site (41KR109) and the Wounded Eye Site (41KR107). Publications in Archeology 19. State Department of Highways and Public Transportation.

Lukowski, P. D.

1988 Archaeological Investigations at 41BX1, Bexar County, Texas. Archaeological Survey Report, No. 135. Center for Archaeological Research, The University of Texas at San Antonio.

Mahoney, R. B.

2001 An Assessment of Documents and Collections from 41CM111, Comal County, Texas. Report prepared for Texas Department of Transportation, Environmental Affairs Division March 2001. Copy on file at the Center for Archaeological Research, The University of Texas at San Antonio.

2002 National Register of Historic Places Eligibility Test Excavations at 41BX1421, Bexar County, Texas. Archaeological Survey Report, Number 322. Center for Archaeological Research, The University of Texas at San Antonio. Archeology Studies Program, Report Number 41. Environmental Affairs Division, Texas Department of Transportation, Austin.

Mahoney, R. B., and S. A. Tomka

2001 National Register Eligibility Testing of 41 MM340 and 41MM341, along Little River, Milam County, Texas. Archaeological Survey Report, No. 303, Center for Archaeological Research, The University of Texas at San Antonio. Archeological Studies Program, Report No. 30, Environmental Affairs Division, Texas Department of Transportation, Austin.

Mahoney, R. B., R. P. Mauldin, and S. A. Tomka

2002 Archeological Data Recovery Excavations along Becerra Creek (41WB556), Webb County, Texas. Archaeological Survey Report, Number 321. Center for Archaeological Research, The University of Texas at San Antonio. Archeology Studies Program, Report Number 44. Environmental Affairs Division, Texas Department of Transportation, Austin. 
McBrearty, S., L. Bishop, T. Plummer, R. Dewar, and N. Conard

1998 Tools Underfoot: Human Trampling as an Agent of Lithic Artifact Edge Modification. American Antiquity 63(1):108-129.

McKinney, W. W.

1981 Early Holocene Adaptations in Central and Southern Texas: The Problem of the Paleo-Indian-Archaic Transition. Bulletin of the Texas Archeological Society 52:91-120.

Miller, E. O., and E. B. Jelks

1952 Archeological Excavations at the Belton Reservoir, Coryell County, Texas. Bulletin of the Texas Archeological Society 23:168-217.

Mueggenborg, H. E.

1994 Excavations at the Blue Hole Site, Uvalde County, Texas, 1990. Bulletin of the Texas Archeological Society 62:174.

Nickels, D. L., C. B. Bousman, J. D. Leach, and D. A. Cargill

2001 Test Excavations at the Culebra Creek Site, 41BX126, Bexar County, Texas. Archaeological Survey Report, Number 265. Center for Archaeological Research, The University of Texas at San Antonio. Archeology Studies Program, Report 3. Environmental Affairs Division, Texas Department of Transportation, Austin.

Nickels, D. L., and R. P. Mauldin

2001 An Archaeological Survey of Twin Buttes Reservoir, Tom Green County, Texas. Archaeological Survey Report, No. 300. Center for Archaeological Research, The University of Texas at San Antonio.

Nordt, L. C.

1992 Archaeological Geology of the Fort Hood Military Reservation, Fort Hood, Texas. United States Army Fort Hood Archaeological Resource Management Series Research Report No. 25. Fort Hood.

1993 Archaeological Geology of the Fort Hood Military Reservation, Fort Hood, Texas. United States Army Fort Hood Archaeological Resource Management Series Research Report No. 28. Addendum to Research Report No. 25. Fort Hood.

1996 Geoarchaeology of 41BX47, Upper Leon Creek Basin. In Archaic Land Use of Upper Leon Creek Terraces: Archaeological Testing in Northern Bexar County, Texas, edited by C. L. Tennis, pp. 11-19. Archaeological Survey Report Number 234. Center for Archaeological Research, The University of Texas San Antonio.

2001 Geoarchaeology of 41BX126. In Test Excavations at the Culebra Creek Site, 41BX126, Bexar County, Texas, by D. L. Nickels, C. B. Bousman, J. D. Leach, and D. A. Cargill, pp. 36-44. Archaeological Survey Report, Number 265. Center for Archaeological Research, The University of Texas at San Antonio. Archeology Studies Program, Report 3. Environmental Affairs Division, Texas Department of Transportation, Austin.

Nordt, L. C., T. W. Boutton, J. S. Jacob, and R. Mandel

1994 Late Quaternary Climates of Central Texas Based on the Stable Isotopic Composition of Organic Carbon. Program and Abstracts, 52nd Plains Conference, 65th Annual Meeting of the Texas Archeological Society, Lubbock.

Orchard, C. D., and T. N. Campbell

1954 Evidences of Early Man from the Vicinity of San Antonio, Texas. The Texas Journal of Science 6(4).

1960 Southwestern Pottery Sites in the Vicinity of San Antonio, Texas. Texas Archeology 4(2):7-8. 
Patterson, P. E.

1987 Archaeological Excavations at 41LL78, The Slab Site, Llano County, Texas. Publications in Archaeology, Report No. 34. State Department of Highways and Public Transportation, Austin.

Pearl, F. B., M. R. Waters, H. J. Shafer, and V. P. Tchakerian

2003 A Geoarchaeological Survey of the Upper Lampasas River, and Underfit Stream in Central Texas. Paper submitted to Quaternary Research and currently in review.

Potzger, J. E., and B. C. Tharp

1943 Pollen Record of Canadian Spruce and Fir from a Texas Bog. Science 98:584.

1947 Pollen Profile from a Texas Bog. Ecology 28:274-280.

1954 Pollen Study of Two Bogs in Texas. Ecology 35:462-466.

Prewitt, E. R.

1981 Cultural Chronology in Central Texas. Bulletin of the Texas Archeological Society 52:65-89.

1982 Archaeological Investigations at the Loeve-Fox, Loeve, and Tombstone Bluff Sites in the Granger Lake District of Central Texas. Archaeological Investigations in the San Gabriel Reservoir Districts, Central Texas, vol. 4. Institute of Applied Sciences, North Texas State University, Denton.

1983 Andice: An Early Archaic Dart Point Type. La Tierra 10(3):17-40.

1985 From Circleville to Toyah: Comments on Central Texas Chronology. Bulletin of the Texas Archeological Society 54:201-238.

Prilliman, K., and C. B. Bousman

1998 Unifacial Tools. In Wilson-Leonard, An 11,000-year Archeological Record of Hunter-Gatherers in Central Texas, Volume II: Chipped Stone Artifacts, edited by M. B. Collins, pp. 597-632. Studies in Archeology 31. Texas Archeological Research Laboratory, The University of Texas at Austin. Archeology Studies Program, Report 10. Environmental Affairs Division, Texas Department of Transportation, Austin.

Quigg, J. M., C. Lintz, G. Smith, and S Wilcox

2000 The Lino Site: A Stratified Late Archaic Campsite in a Terrace of the San Idelfonzo Creek, Webb County, Southern Texas. Technical Report No. 23756. TRC Mariah Associates, Inc., Austin.

Ramsey, C. B.

2000 OxCal Program Version 3.5. Radiocarbon Accelerator Unit, University of Oxford. Oxford, U.K.

Reynolds, R. L., and J. W. King

1995 Magnetic Records of Climate Change. U.S. National Report to I.U.G.G., 1991-1994. American Geophysical Union. <http://www.agu.ong/revgeophys/reyno100/reyno100.html> Accessed April 2001.

Ricklis, R. A., and M. B. Collins

1994 Archaic and Late Prehistoric Human Ecology in the Middle Onion Creek Valley, Hays County, Texas. Studies in Archeology 19. Texas Archeological Research Laboratory, The University of Texas at Austin.

Robinson, R. L.

1979 Biosilica and Climatic Change at 41GD21 and 41GD21A. In Archaeological Investigations of Two Prehistoric Sites on the Coleto Creek Drainage, Goliad County, Texas, edited by D. E. Fox, pp. 102-113. Archaeological Survey Report, No. 69. Center for Archaeological Research, The University of Texas at San Antonio. 
1982 Biosilica Analysis of Three Prehistoric Archaeological Sites in the Choke Canyon Reservoir, Live Oak County, Texas: Preliminary Summary of Climatic Implications. In Archaeological Investigations at Choke Canyon Reservoir, South Texas: The Phase I Findings, edited by G. D. Hall, S. L. Black, and C. Graves, pp. 597-610. Choke Canyon Series, No. 5. Center for Archaeological Research, The University of Texas at San Antonio.

Schiffer, M. B.

1975 The Effects of Occupation Span on Site Content. In The Cache River Archeological Project: An Experiment in Contract Archeology, edited by M. B. Schiffer and J. H. House, pp. 265-269. Research Series No. 8. Arkansas Archeological Survey. Fayetteville.

Schuetz, M. K.

1966 The Granberg Site: An Archaic Indian Habitation in Bexar County, Texas. Witte Museum Studies, Number 1. San Antonio.

Sellards, E. H., W. S. Adkins, and F. B. Plummer

1958 The Geology of Texas: Volume 1: Stratigraphy (4 ${ }^{\text {th }}$ printing). The University of Texas Bulletin 3232. Austin.

Shafer, H. J.

1963 Test Excavations at the Youngsport Site: A Stratified Terrace Site in Bell County, Texas. Bulletin of the Texas Archeological Society 34:57-81.

1971 Investigations into South Plains Prehistory, West Central Texas. Survey Reports No. 20. Papers of the Texas Archeological Salvage Project, The University of Texas at Austin.

1979 Technological Study of Two Maya Lithic Workshops at Colha, Belize. In The Colha Project, 1979: A Collection of Interim Papers, edited by T. R. Hester, pp. 28-78. Center for Archaeological Research, The University of Texas at San Antonio.

1986 Ancient Texans: Rockart and Lifeway of the Lower Pecos. Texas Monthly Press, Austin.

Shafer, H. J., and V. M. Bryant

1977 Archeological and Botanical Studies at Hinds Cave, Val Verde County, Texas. Special Series Number 1. Anthropology Laboratory, Texas A\&M University, College Station.

Shafer, H. J., and T. R. Hester

1986 Maya Stone-Tool Craft Specialization and Production at Colha, Belize: A Reply to Mallory. American Antiquity 51:158-166.

Shafer, H. J., and R. G. Holloway

1976 Organic Residue Analysis in Determining Stone Tool Function. In Lithic Use-Wear Analysis, edited by B. Hayden, pp. 385-400. Academic Press, New York.

Shott, M. J.

1989 On Tool-Class Use Lives and the Formation of the Archaeological Assemblages. American Antiquity 54: $9-30$.

Soil Survey Division Staff

1993 Soil Survey Manual. U.S. Department of Agriculture Handbook No. 18. Washington D.C. Printing Press. 
Sollberger, J. B.

1971 A Technical Study of Beveled Knives. Plains Anthropologist 16(53):209-218.

Sorrow, W. M.

1969 Archeological Investigations at the John Ischy Site: A Burned Rock Midden in Williamson County, Texas. Papers of the Texas Archeological Salvage Project, No. 18. University of Texas at Austin.

Sorrow, W. M., H. J. Shafer, and R. E. Ross

1967 Excavations at Stillhouse Hollow Reservoir. Papers of the Texas Archeological Salvage Project, No. 11. University of Texas at Austin.

Southern Regional Climate Center (SRCC)

2003a Normal Monthly Precipitation. <http://www.srcc.lsu.edu/7100/prcp/TX.html> Accessed February 2003.

2003b Normal Daily Average Temperature. <http://www.srcc.lsu.edu/7100/tavg/TX.html > Accessed February 2003.

2003c Normal Daily Minimum Temperature. $<$ http://www.srcc.lsu.edu/7100/tmin/TX.html $>$ Accessed February 2003.

Stackelbeck, K. L.

2000 Refit Analysis. In The 1999 Excavations at the Big Eddy Site (23CE426), edited by N. H. Liponet, J. H. Ray, and M. D. Conner, pp. 154-162. Special Publication No. 3. Center for Archaeological Research, Southwest Missouri State University, Springfield.

Stevenson, R. L.

1951 A Preliminary Survey of Canyon Reservoir, Comal County, Texas. Report of the River Basin Surveys, Smithsonian Institution, Austin Office, Austin.

Story, D. A., and H. J. Shafer

19651964 Excavations at Waco Reservoir, McLennan County, Texas: The Baylor and Britton Sites. Miscellaneous Papers No. 6. Texas Archeological Salvage Project, The University of Texas at Austin.

Stuvier, M., and P. J. Reimer

1993 Extended ${ }^{14} \mathrm{C}$ Database and Revised CALIB Radiocarbon Calibration Program. Radiocarbon 35:215-230.

Suhm, D. A.

1948 The Merrill Site: Archaeological Remains Associated with Alluvial Terrace Deposits. Bulletin of the Texas Archeological Society 19:7-35.

1957 Excavations at the Smith Rockshelter, Travis County. The Texas Journal of Science 9(1):26-58.

1959 The Williams Site and Central Texas Archeology. The Texas Journal of Science 11(2):218-250.

Suhm, D. A., A. D. Krieger, and E. B. Jelks

1954 An Introductory Handbook of Texas Archeology. Bulletin of the Texas Archeological Society 25.

Sullivan, L. A.

1998 Ground and Other Non-Chipped Stone Artifacts. In Wilson-Leonard: An 11,000-year Archeological Record of Hunter-Gatherers in Central Texas: Volume III: Artifacts and Special Artifact Studies, assembled and edited by M. B. Collins, pp. 703-722. Studies in Archeology 31. Texas Archeological Research Laboratory, The University of Texas at Austin. Archeology Studies Program, Report 10. Environmental Affairs Division, Texas Department of Transportation, Austin. 
Taylor, A. J., and C. L. Highley

1995 Archeological Investigations at the Loma Sandia Site (41LK28), A Prehistoric Cemetery and Campsite in Live Oak County, Texas. Studies in Archeology No. 20. Texas Archeological Research Laboratory, The University of Texas at Austin.

Texas Historical Commission (THC)

2002 Texas Archeological Sites Atlas. <http://www.pedernales.thc.state.tx.us/> Accessed April 2002.

Thoms, A. V., D. D. Kuehn, B. W. Olive, J. E. Dockall, P. A. Clabaugh, and R. D. Mandel

1996 Early and Middle Holocene Occupations at the Richard Beene Site: The 1995 Southern Texas Archaeological Association Field School Project. La Tierra 23(4):8-36.

Tomka, S. A.

2002 Hunter-Gatherer Technological Organization during the Archaic in South Texas. Paper presented at the 73rd Annual Meeting of the Texas Archeological Society, Laredo.

Tomka, S. A., R. B. Mahoney, and R. P. Mauldin

2002 A Research Design for Analysis of Archeological Material from Data Recovery Efforts at 41MM340, Milam County, Texas. Manuscript on file at the Center for Archaeological Research, The University of Texas at San Antonio.

Tomka, S. A., T. K. Perttula, and R. J. Hard

1997 Archaeology of the Rio Grande and Central Coastal Plains, Texas: A Planning Document. Archaeological Survey Report, No. 266. Center for Archaeological Research, The University of Texas at San Antonio. Draft.

Toomey, R. S.

1993 Late Pleistocene and Holocene Faunal Environmental Changes at Hall's Cave, Kerr County, Texas. Ph.D. dissertation, The University of Texas at Austin. University Microfilms, Ann Arbor.

Toomey, R. S., M. D. Blum, and S. Valastro, Jr.

1993 Late Quaternary Climates and Environments of the Edwards Plateau, Texas. Global and Planetary Change 7:299-320.

Toomey, R. S., and T. W. Stafford, Jr.

1994 Paleoenvironmental and Radiocarbon Study of the Deposits from Hall's Cave, Kerr County, Texas. Program and Abstracts, 52nd Plains Conference, 65th Annual Meeting of the Texas Archeological Society. Lubbock.

Turner, E. S., and T. R. Hester

1999 A Field Guide to Stone Artifacts of Texas Indians. 3rd Edition. Gulf Publishing, Houston.

Turpin, S. A.

1982 Seminole Canyon: The Art and the Archeology, Val Verde County, Texas. Texas Archeological Survey, Research Report 83. The University of Texas at Austin. 
Valdez, Jr., F., and A. J. McGraw

1977 An Archaeological Evaluation of Three Prehistoric Sites, Upper Cibolo Creek Watershed, Kendall County, South Central Texas. Archaeological Survey Report, No. 44. Center for Archaeological Research, The University of Texas at San Antonio.

Weir, F. A.

1979 Greenhaw: An Archaic Site in Central Texas. Bulletin of the Texas Archeological Society 50:5-67.

Wesolowsky, A. B., T. R. Hester, and D. R. Brown

1976 Archeological Investigations at the Jetta Court Site (41TV151), Travis County, Texas. Bulletin of the Texas Archeological Society 47:25-87.

Wood, G. P.

1994 Archaeological Testing of 41BX126, Bexar County, Texas. Texas Department of Transportation, Austin.

Woolford, S. W.

1935 Types of Sites in Bexar County, Texas. Archaeological Bulletin No. 4. Witte Museum, San Antonio.

Word, J. H., and C. L. Douglas

1970 Excavations at Baker Cave, Val Verde County, Texas. Bulletin No. 16. Texas Memorial Museum, The University of Texas at Austin.

Young, W. C.

1985 Archaeological Excavations at Site 41BT6, Burnet County, Texas. Publications in Archaeology, Report No. 28. Texas State Department of Highways and Public Transportation, Austin. 



\title{
Appendix A
}

\section{Soil-Stratigraphic Descriptions}

\author{
by \\ Lee C. Nordt
}


BHT-1; early Holocene alluvium; north side of FM 306, connected to U2 and U4; west wall; calcareous throughout.

A $\quad 0-16 \mathrm{~cm}$; very dark grayish brown (10YR 3/2) clay loam; moderate fine and medium subangular blocky; hard; many fine worm casts; few fine snails fragments; gradual smooth.

Bw 16-37 cm; brown (10YR 4/3) clay loam; moderate medium and coarse subangular blocky; hard; few medium dark grayish brown (10YR 3.5/2) biotubules; common fine worm casts; burned rock at base of horizon; gradual smooth.

Bk1 37-80 cm; yellowish brown (10YR 4.5/4) silty clay loam; moderate medium and coarse subangular blocky; hard; few fine worm casts, and few medium brown (10YR 4/3) biotubules; $2 \%$ carbonate filaments; common fine snail fragments; snail bed at base of horizon; gradual smooth.

Bk2 80-125+ cm; yellowish brown (10YR 5/4) silty clay loam; weak coarse angular blocky; hard; few fine worm casts, and few medium brown ( 7.5 YR $5 / 4)$ biotubules; $2 \%$ carbonate filaments; few medium snail fragments; snail bed at base of horizon.

BHT-2; early Holocene alluvium; south side of FM 306, 15 west of to U8 and U21; north wall; calcareous throughout.

fill $\quad$ 0-8 cm; brown (10YR 5/3) clay loam; moderate medium subangular blocky; hard; $2 \%$ limestone clasts, 0.5 to $1.5 \mathrm{~cm}$, angular; clear wavy.

Bw $\quad 8-21 \mathrm{~cm}$; yellowish brown (10YR 5.5/4) clay loam; moderate coarse subangular; hard; gradual smooth.

Bk 21-64 cm; yellowish brown (10YR 5/4) clay loam; weak coarse prismatic; hard; common medium snails; $1 \%$ carbonate filaments; burned rock at $50 \mathrm{~cm}$; gradual smooth.

Bw1 64-101 cm; yellowish brown (10YR 5/4) clay loam; weak coarse prismatic; hard; few medium snails; gradual smooth.

Bw2 101-186 cm; yellowish brown (10YR 5/4) clay loam; weak coarse prismatic; hard; few medium snails; gradual smooth.

BC 186-230+ cm; light yellowish brown (10YR 6/4) loam; weak coarse prismatic; friable; few medium snails.

BHT-3; late over early Holocene alluvium; south side of FM 306; calcareous throughout.

fill $\quad$-12 cm; brown (10YR 4.5/3) clay loam; moderate fine and medium subangular blocky; hard; $2 \%$ limestone clasts, 0.5 to $1.5 \mathrm{~cm}$, angular; clear wavy.

A 12-46 cm; dark grayish brown (10YR 4/2) sandy clay loam; weak coarse subangular blocky; friable; pebble line at base of horizon, 1 to $1.5 \mathrm{~cm}$ pebbles, angular to subrounded; gradual smooth.

BA 46-60 cm; brown (10YR 4/3) sandy clay loam; weak coarse subangular blocky; friable; clear smooth. 
$\mathrm{Ab} \quad$ 60-81 cm; brown (10YR 4/3) clay loam; weak coarse angular blocky; friable; $1 \%$ carbonate filaments; gradual smooth.

Bk1 81-110 cm; yellowish brown (10YR 5/4) clay loam; weak coarse prismatic; hard; $1 \%$ carbonate filaments; gradual smooth.

Bk2 110-175+ cm; yellowish brown (10YR 5/4) clay loam; weak coarse prismatic; hard; $1 \%$ carbonate filaments.

BHT-4; late Holocene alluvium; south side of FM 306, 90 m east of Guadalupe River; calcareous throughout.

fill $\quad 0-9 \mathrm{~cm}$; very dark gray (10YR 3/1) silty clay loam; moderate fine and medium subangular blocky; hard; $60 \%$ limestone clasts, 0.3 to $3 \mathrm{~cm}$, angular; abrupt wavy.

fill 9-17 cm; very dark grayish brown (10YR 3/2) sandy clay loam; massive; hard; $30 \%$ limestone clasts, 0.3 to $3 \mathrm{~cm}$, angular; abrupt wavy.

fill $\quad 17-28 \mathrm{~cm}$; mixed dark grayish brown (10YR 4/2) and brown (10YR 4/3) clay loam; weak coarse subangular blocky to massive; firm; $15 \%$ limestone clasts, 0.3 to $3 \mathrm{~cm}$, angular; clear wavy.

$\mathrm{Ab} \quad 28-73 \mathrm{~cm}$; mixed very dark gray (10YR 3.5/1) and very dark grayish brown (10YR 4/2) silty clay loam; weak coarse subangular blocky; firm; abrupt wavy.

C1 $73-96 \mathrm{~cm}$; 70\% pebbles and cobbles, 1 to $6 \mathrm{~cm}$, subrounded, moderately sorted; very dark grayish brown (10YR 3.5/2) loam matrix; abrupt wavy.

C2 96-135+ cm; 80\% pebbles and cobbles, 1 to $40 \mathrm{~cm}$, subrounded; very dark grayish brown (10YR 4/2) loam matrix.

BHT-5; late Holocene alluvium; south of FM 306 adjacent to Cordova Creek; calcareous throughout.

fill $\quad 0-85 \mathrm{~cm}$; brown, red, and yellow gravelly loam; abrupt wavy.

Bw $\quad 85-100 \mathrm{~cm}$; pale brown (10YR 5.5/3) sandy clay loam; massive; friable; few medium distinct brownish yellow (10YR 6/6) biotubules; few fine and medium snails; clear smooth.

Ab1 100-131 cm; yellowish brown (10YR 5/4) sandy clay loam; weak coarse subangular blocky; very friable; few medium distinct brownish yellow (10YR 6/6) biotubules; $1 \%$ pebbles 0.2 to $1 \mathrm{~cm}$, angular; few fine and medium snails; clear smooth.

Ab2 131-170 cm; yellowish brown (10YR 5/4) clay loam; moderate medium subangular blocky; friable; 5\% pebbles, 0.2 to $1.5 \mathrm{~cm}$, angular; few medium distinct brownish yellow (10YR 6/6) biotubules; few fine and medium snails; $10 \mathrm{~cm}$ thick gravel bed at base, 0.3 to $3 \mathrm{~cm}$ pebbles, angular; abrupt wavy.

BC 170-262 cm; brownish yellow (10YR 6/6) clay loam; massive to weak coarse prismatic; friable; few coarse brown (10YR 4/3) gopher infills; few fine and medium snails. 

Appendix B

Radiocarbon Dating Results 


\begin{tabular}{|c|c|c|c|}
\hline Sample Data & $\begin{array}{c}\text { Measured } \\
\text { Radiocarbon Age }\end{array}$ & $\begin{array}{c}13 \mathrm{C} / 12 \mathrm{C} \\
\text { Ratio }\end{array}$ & $\begin{array}{c}\text { Conventional } \\
\text { Radiocarbon Age }\left(^{*}\right)\end{array}$ \\
\hline $\begin{array}{l}\text { Beta - } 166715 \\
\text { SAMPLE : 02H1-3 } \\
\text { ANALYSIS : Radiometric-Stan } \\
\text { MATERIAL/PRETREATMEN } \\
\text { 2 SIGMA CALIBRATION : }\end{array}$ & $\begin{array}{l}4820+/-60 \mathrm{BP} \\
\mathrm{y} \\
\text { material): acid/alkali/a } \\
3700 \text { to } 3510 \text { (Cal BP } 5\end{array}$ & $\begin{array}{l}-25.1 \mathrm{o} / \mathrm{oo} \\
\mathrm{AND} \mathrm{Cal} \mathrm{BC} \\
\end{array}$ & $\begin{array}{r}4820+/-60 \text { BP } \\
\text { (Cal BP } 5370 \text { to } 5340) \\
\end{array}$ \\
\hline $\begin{array}{l}\text { Beta - } 166716 \\
\text { SAMPLE : 04I2-2 } \\
\text { ANALYSIS : AMS-Standard de } \\
\text { MATERIAL/PRETREATMEN } \\
\text { 2 SIGMA CALIBRATION : }\end{array}$ & $\begin{array}{l}5030+/-40 \text { BP } \\
\text { material): acid/alkali/a } \\
3930 \text { to } 3860 \text { (Cal BP } 5\end{array}$ & $\begin{array}{l}-27.5 \mathrm{o} / \mathrm{oo} \\
\mathrm{AND} \mathrm{Cal} \mathrm{BC}\end{array}$ & $\begin{array}{r}4990+/-40 \text { BP } \\
\text { (Cal BP } 5760 \text { to } 5620) \\
\end{array}$ \\
\hline $\begin{array}{l}\text { Beta - } 166717 \\
\text { SAMPLE : 08H-3 } \\
\text { ANALYSIS : Radiometric-Stan } \\
\text { MATERIAL/PRETREATMEN } \\
\text { 2 SIGMA CALIBRATION : }\end{array}$ & $\begin{array}{l}\quad 4780+/-60 \text { BP } \\
\text { y material): acid/alkali/a } \\
3660 \text { to } 3490 \text { (Cal BP } 5\end{array}$ & $\begin{array}{l}-25.5 \mathrm{o} / \mathrm{oo} \\
\mathrm{AND} \mathrm{Cal} \mathrm{BC}\end{array}$ & $\begin{array}{r}4770+/-60 \mathrm{BP} \\
\text { (Cal BP } 5410 \text { to } 5320) \\
\end{array}$ \\
\hline $\begin{array}{l}\text { Beta - } 166718 \\
\text { SAMPLE : 2IC3 } \\
\text { ANALYSIS : AMS-Standard de } \\
\text { MATERIAL/PRETREATMEN } \\
\text { 2 SIGMA CALIBRATION : }\end{array}$ & $\begin{array}{l}4790+/-40 \text { BP } \\
\text { material): acid/alkali/a } \\
3650 \text { to } 3510 \text { (Cal BP } 5\end{array}$ & $\begin{array}{l}-25.5 \mathrm{o} / \mathrm{oo} \\
\mathrm{AND} \mathrm{Cal} \mathrm{BC} \\
\end{array}$ & $\begin{array}{c}4780+/-40 \mathrm{BP} \\
\text { (Cal BP } 5370 \text { to } 5340) \\
\end{array}$ \\
\hline $\begin{array}{l}\text { Beta - } 166719 \\
\text { SAMPLE : } 21 \mathrm{D} 2 \\
\text { ANALYSIS : AMS-Standard de } \\
\text { MATERIAL/PRETREATMEN } \\
\text { 2 SIGMA CALIBRATION : }\end{array}$ & $\begin{array}{l}\quad 4840+/-40 \mathrm{BP} \\
\text { material): acid/alkali/a } \\
680 \text { to } 3620 \text { (Cal BP } 5 \\
\end{array}$ & $\begin{array}{l}-24.8 \mathrm{o} / \mathrm{oo} \\
\text { AND Cal BC } \\
\end{array}$ & $\begin{array}{c}\quad 4840+/-40 \text { BP } \\
\text { Cal BP } 5530 \text { to } 5480 \text { ) } \\
\end{array}$ \\
\hline $\begin{array}{l}\text { Beta - } 166720 \\
\text { SAMPLE : BHT2-1 } \\
\text { ANALYSIS : Radiometric-Stan } \\
\text { MATERIAL/PRETREATMEN } \\
2 \text { SIGMA CALIBRATION : }\end{array}$ & $\begin{array}{l}4350+/-70 \mathrm{BP} \\
\mathrm{y} \\
\text { material): acid/alkali/a } \\
3270 \text { to } 3240 \text { (Cal BP } 5\end{array}$ & $-25.1 \mathrm{o} / \mathrm{oo}$ & (Cal BP 5060 to 4820 ) \\
\hline $\begin{array}{l}\text { Beta - } 166721 \\
\text { SAMPLE : BHT5 } \\
\text { ANALYSIS : AMS-Standard de } \\
\text { MATERIAL/PRETREATMEN } \\
2 \text { SIGMA CALIBRATION : }\end{array}$ & $\begin{array}{l}2820+/-40 \mathrm{BP} \\
\text { sediment): acid washe } \\
270 \text { to } 1000 \text { (Cal BP } 3\end{array}$ & $-18.5 \mathrm{o} / \mathrm{oo}$ & $2930+/-40 \mathrm{BP}$ \\
\hline
\end{tabular}




\section{CALIBRATION OF RADIOCARBON AGE TO CALENDAR YEARS}

$$
\text { (Variables: C 13/C 12=-25.1:lab. mult=1) }
$$

Laboratory number: Beta-166715

Conventional radiocarbon age: $4820 \pm 60 \mathrm{BP}$

2 Sigm a calibrated results: Cal BC 3700 to 3510 (Ca I B P 5650 to 5460) and (95\% probability) Cal BC 3420 to 3390 (Cal B P 5370 to 5340 )

Intercept data

Intercept of radiocarbon age

with calibration curve: Cal BC 3640 (Cal B P 5590)

1 Sigma calibrated results: Cal BC 3660 to 3620 (Cal B P 5600 to 5580) and (68\% probability) Cal BC 3580 to 3530 (Cal B P 5530 to 5480 )

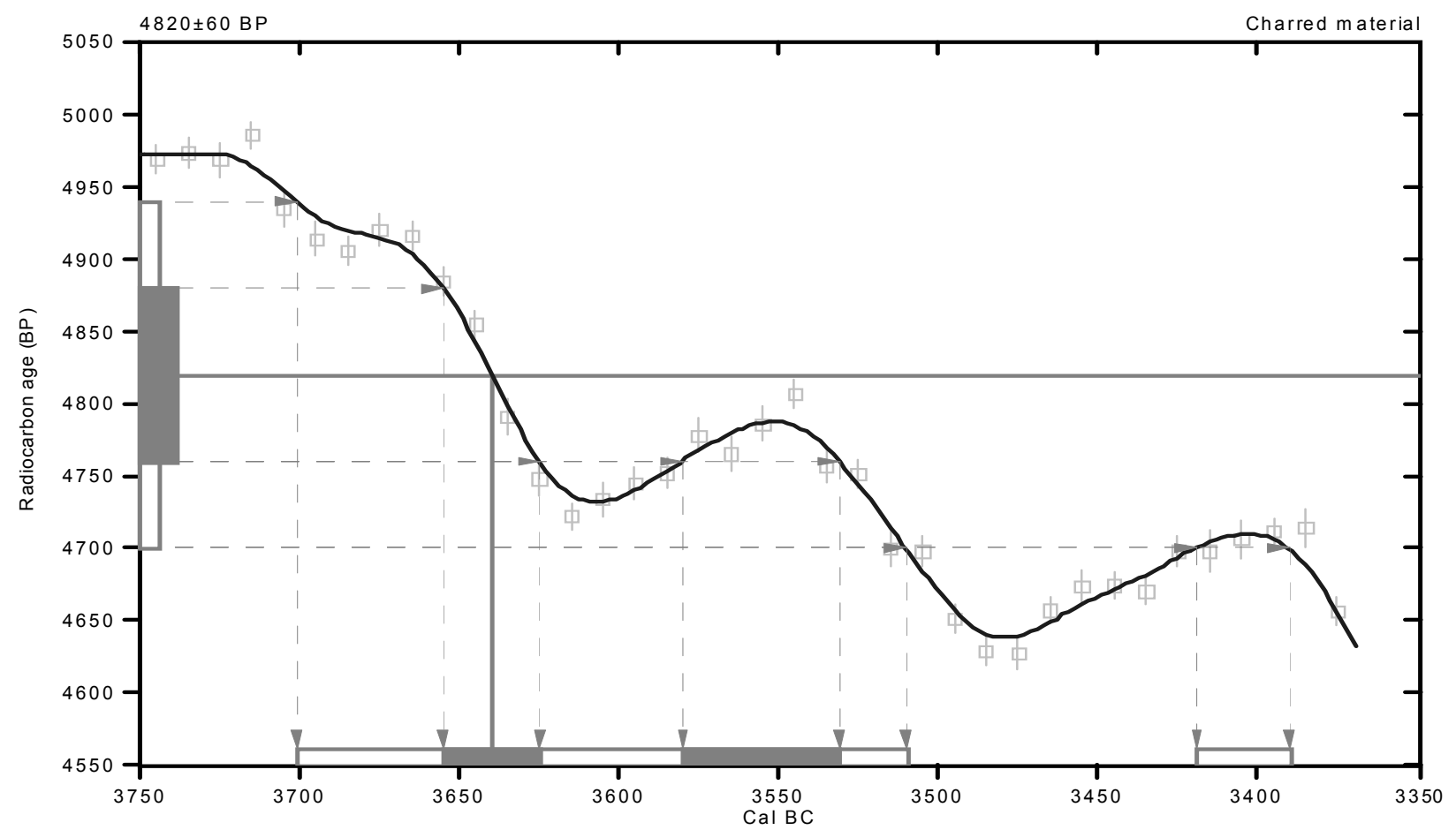

References:

Database used

Calibration Database

Editorial Com ment

Stuiver, M., van der Plicht, H., 1998, Radiocarbon 40(3), pxi-xiii

IN TCAL98 Radiocarbon Age Calibration

Stuiver, M., et. al., 1998, Radiocarbon 40(3), p1041-1083

$M$ ath em atics

A Simplified Approach to Calib rating C14 Dates

Talma, A. S., Vogel, J. C., 1993, Radiocarbon 3 5(2), p317-322

\section{Beta Analytic Inc.}

4985 SW74 Court, Miami, Florida 33155 USA Tel: (305)6675167•Fax:(305)6630964・E-Mail: beta@radiocarbon.com 


\title{
CALIBRATION OF RADIOCARBON AGE TO CALENDAR YEARS
}

\author{
$\frac{(\text { Variables: } \mathrm{C} 13 / \mathrm{C} 12=-27.5: \mathrm{lab} . \mathrm{mult}=1)}{}$ \\ Laboratory number: Beta-166716 \\ Conventional radiocarbon age: $4990 \pm 40$ BP \\ 2 Sigm a calibrated results: Cal BC 3930 to 3860 (Ca I B P 5880 to 5810 ) and \\ (95\% probability) Cal BC 3810 to 3670 (Cal B P 5760 to 5620 ) \\ Intercept data
}

Intercept of radiocarbon age

with calibration curve:

Cal B C 3770 (Cal B P 5720)

1 Sigma calibrated result: Cal BC 3790 to 3710 (Cal B P 5740 to 5660) (68\% probability)

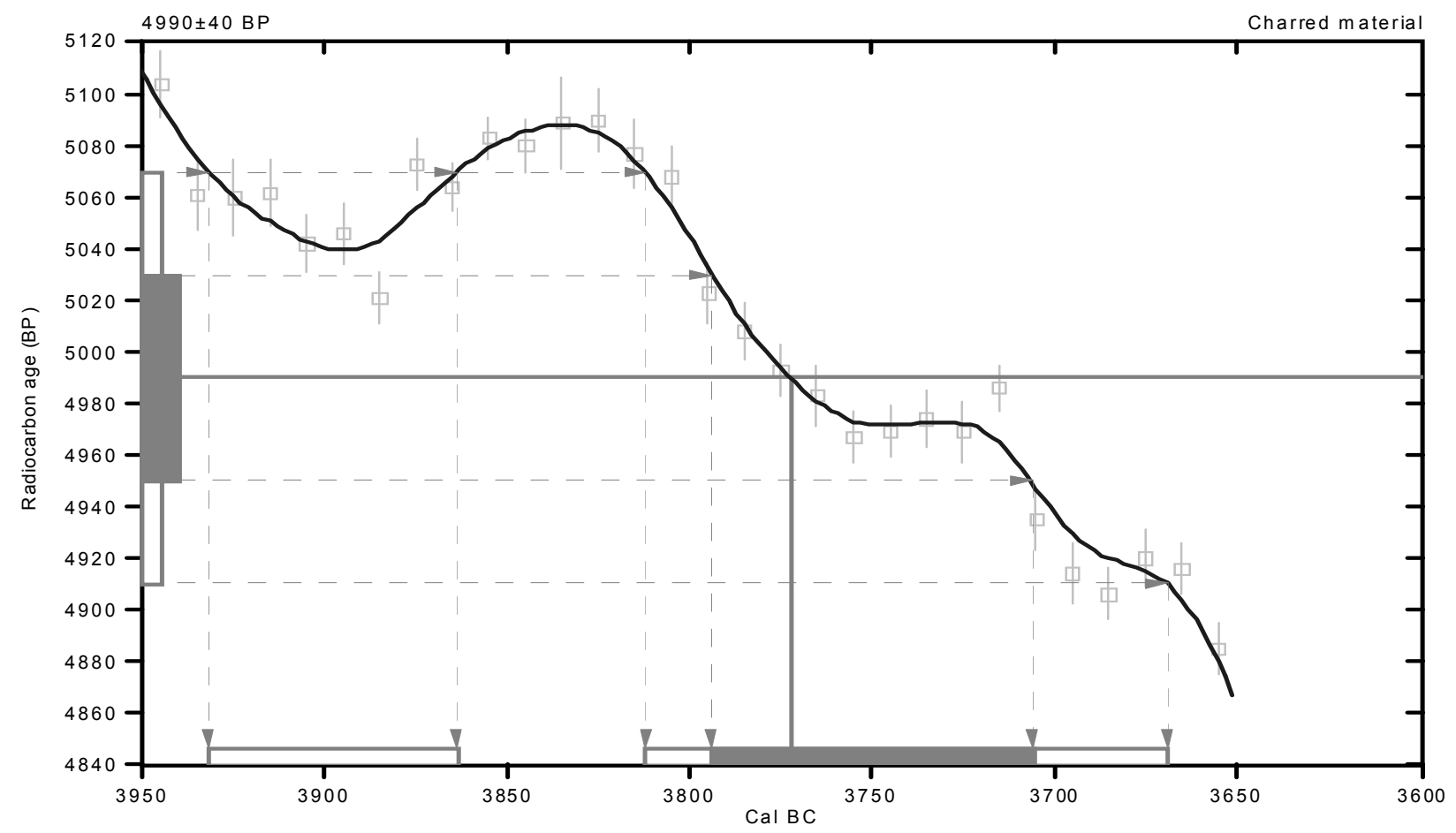

References:

Da tabase used

Calibration Database

Editorial Com ment

Stuiver, M., van der Plicht, H., 1998, Radiocarbon 40(3), pxii-xiii

INTCAL98 Radiocarbon Age Calibration

Stuiver, M., et. al., 1998, Radiocarbon 40(3), p1041-1083

$M$ ath em atics

A Simplified Approach to Calibrating C14 Dates

Talma, A. S., Vogel, J. C., 1993, Radiocarbon 3 5(2), p317-322

\section{Beta Analytic Inc.}

4985 SW 74 Court, Miami, Florida 33155 USA Tel: (305)6675167•Fax:(305)6630964・E-Mail: beta@radiocarbon.com 


\section{CALIBRATION OF RADIOCARBON AGE TO CALENDAR YEARS}

$$
\text { (V ariables: C } 13 / \mathrm{C} 12=-25.5: 1 \mathrm{ab} . \mathrm{mult}=1 \text { ) }
$$

Laboratory number: Beta-166717

Conventional radiocarbon age: $4770 \pm 60 \mathrm{BP}$

2 Sigm a calibrated results: Cal BC 3660 to 3490 (Ca I B P 5610 to 5440) and

(95\% probability) Cal BC 3460 to 3370 (Cal B P 5410 to 5320 )

Intercept data

Intercepts of radiocarbon age

with calibration curve: Cal BC 3630 (Cal B P 5580) and

Cal BC 3570 (Cal B P 5520) and

Cal B C 3540 (Cal B P 5480)

1 Sigma calibrated result: Cal BC 3640 to 3510 (Cal B P 5590 to 5460) (68\% probability)

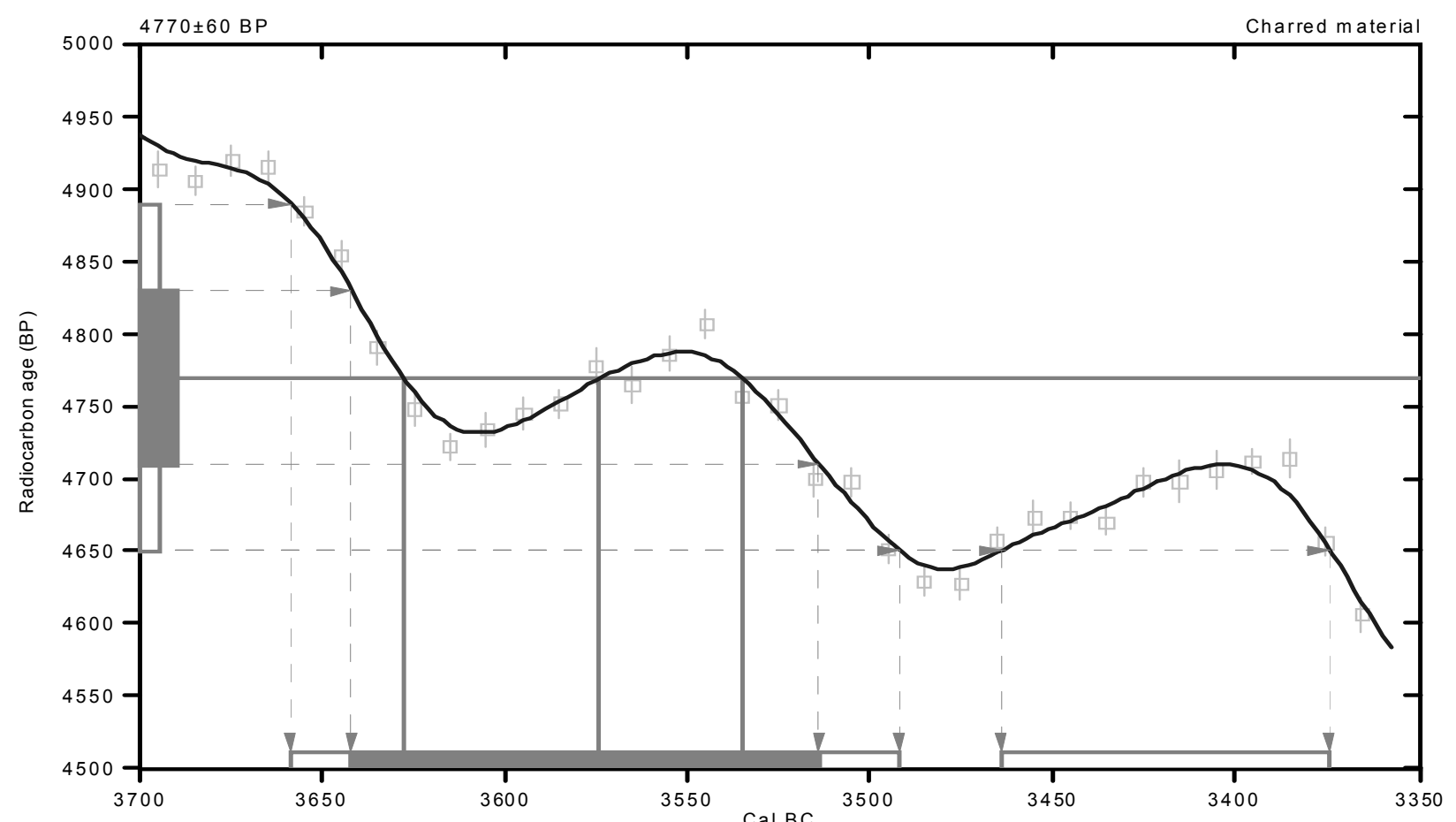

References:

Da tabase used

Calibration Database

Editorial Com ment

Stuiver, M., van der Plicht, H., 1998, Radioca rbon 40(3), pxii-xiii

IN TCAL 98 Radiocarbon Age Calibration

Stuiver, M., et. al., 1998, Radiocarbon 40(3), p1041-1083

$M$ ath ematics

A Simplified Approach to Calibrating C14 Dates

Talma, A. S., Vogel, J. C., 1993, Radiocarbon 35(2), p317-322

\section{Beta Analytic Inc.}

4985 SW74 Court, Miami, Florida 33155 USA Pel: (305)6675167•Fax:(305)6630964・E-Mail: beta@radiocarbon.com 


\title{
CALIBRATION OF RADIOCARBON AGE TO CALENDAR YEARS
}

\author{
(Variables: $\mathrm{C} 13 / \mathrm{C} 12=-25.5: \mathrm{lab} . \mathrm{mult}=1)$ \\ Laboratory number: Beta-166718 \\ Conventional radiocarbon age: $4780 \pm 40 \mathrm{BP}$ \\ 2 Sigm a calibrated results: Cal BC 3650 to 3510 (Cal B P 5600 to 5460) and \\ (95\% probability) Cal BC 3420 to 3390 (Cal B P 5370 to 5340 ) \\ Intercept data \\ Intercepts of radiocarbon age \\ with calibration curve: Cal BC 3630 (Cal B P 5580) and \\ Cal B C 3560 (Cal B P 5520) and \\ Cal B C 3540 (Cal B P 5490) \\ 1 Sigma calibrated results: Cal BC 3640 to 3620 (Cal B P 5590 to 5570 ) and \\ (68\% probability) Cal BC 3600 to 3520 (Cal B P 5540 to 5470 )
}

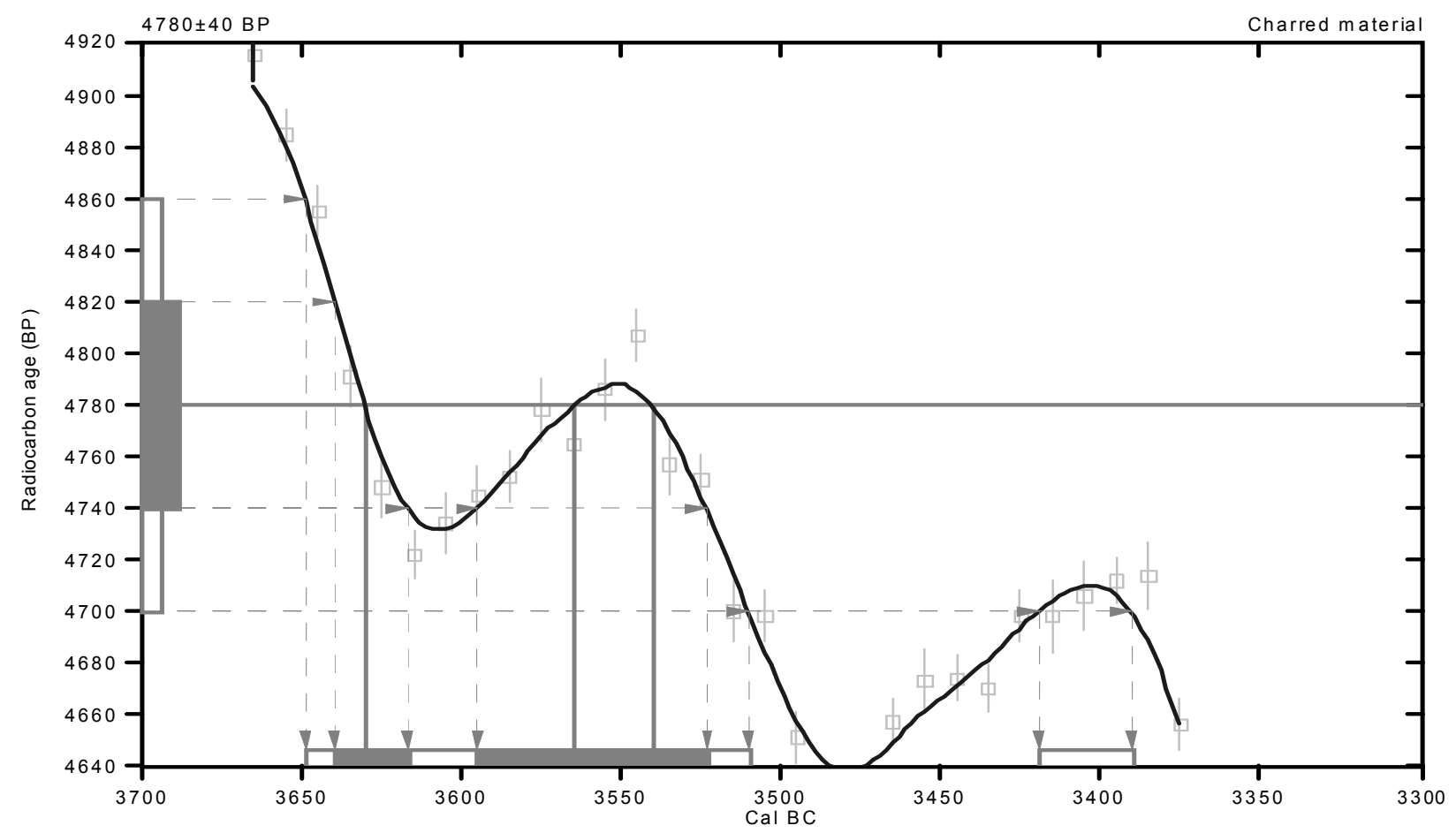

References:

Da tabase used

Calibration Database

Editorial Com ment

Stuiver, M., van der Plicht, H., 1998, Radiocarbon 40(3), pxii-xiii

INTCAL98 Radiocarbon Age Calibration

Stuiver, M., et. al., 1998, Radiocarbon 40(3), p1041-1083

$M$ ath em atics

A Simplified Approach to Calibrating C14 Dates

Talma, A.S., Vogel, J. C., 1993 , Radiocarbon $35(2)$, p317-322

\section{Beta Analytic Inc.}

4985 SW 74 Court, Miami, Florida 33155 USA Tel: (305)6675167・Fax:(305)6630964・E-Mail: beta@radiocarbon.com 


\title{
CALIBRATION OF RADIOCARBON AGE TO CALENDAR YEARS
}

\author{
(Variables: C 13/C 12=-24.8:1ab. $\mathrm{mult}=1$ ) \\ Laboratory number: Beta-166719 \\ Conventional radiocarbon age: $4840 \pm 40 \mathrm{BP}$ \\ 2 Sigm a calibrated results: Cal BC 3680 to 3620 (Cal B P 5640 to 5580) and \\ (95\% probability) Cal BC 3580 to 3530 (Cal B P 5530 to 5480 ) \\ Intercept data
}

Intercept of radiocarbon age

with calibration curve:

Cal B C 3640 (Cal B P 5590)

1 Sigm a calibrated result: (68\% probability)

Cal BC 3660 to 3640 (Cal B P 5600 to 5580)

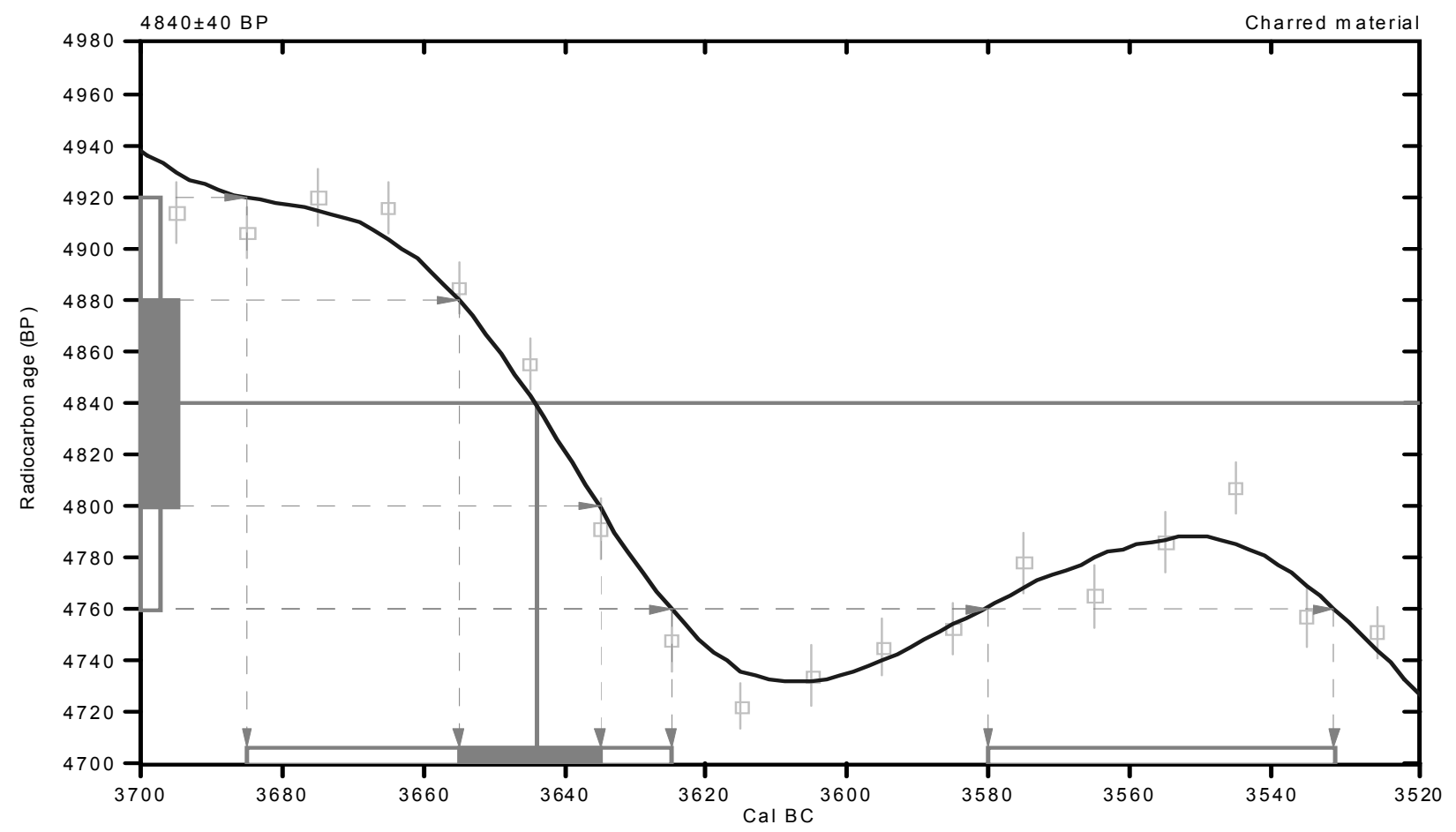

References:

Database used

Calibration Database

Editorial Com ment

Stuiver, M., van der Plicht, H., 1998, Radiocarbon 40(3), pxii-xiii

INTCAL98 Radiocarbon Age Calibration

Stuiver, M., et. al., 1998, Radiocarbon 40(3), p1041-1083

Math ematics

A Simplified Approach to Calibrating C14 Dates

Talma, A. S., Vogel, J. C., 1993, Radiocarbon 35(2), p317-322

\section{Beta Analytic Inc.}

4985 SW74 Court, Miami, Florida 33155 USA Tel: (305)6675167•Fax:(305)6630964・E-Mail: beta@radiocarbon.com 


\title{
CALIBRATION OF RADIOCARBON AGE TO CALENDAR YEARS
}

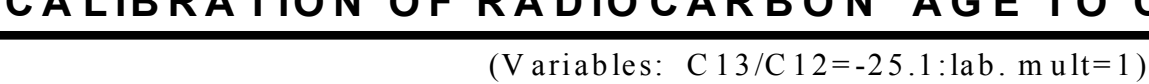 \\ Laboratory number: Beta-166720 \\ Conventional radiocarbon age: $4340 \pm 70 \mathrm{BP}$ \\ 2 Sigm a calibrated results: Cal BC 3270 to 3240 (Cal B P 5220 to 5190 ) and \\ (95\% probability) Cal BC 3110 to 2870 (Cal B P 5060 to 4820 ) \\ Intercept data
}

Intercept of radiocarbon age

with calibration curve:

Cal B C 2920 (Cal B P 4860)

1 Sigma calibrated result: Cal BC 3020 to 2890 (Cal B P 4970 to 4840) (68\% probability)

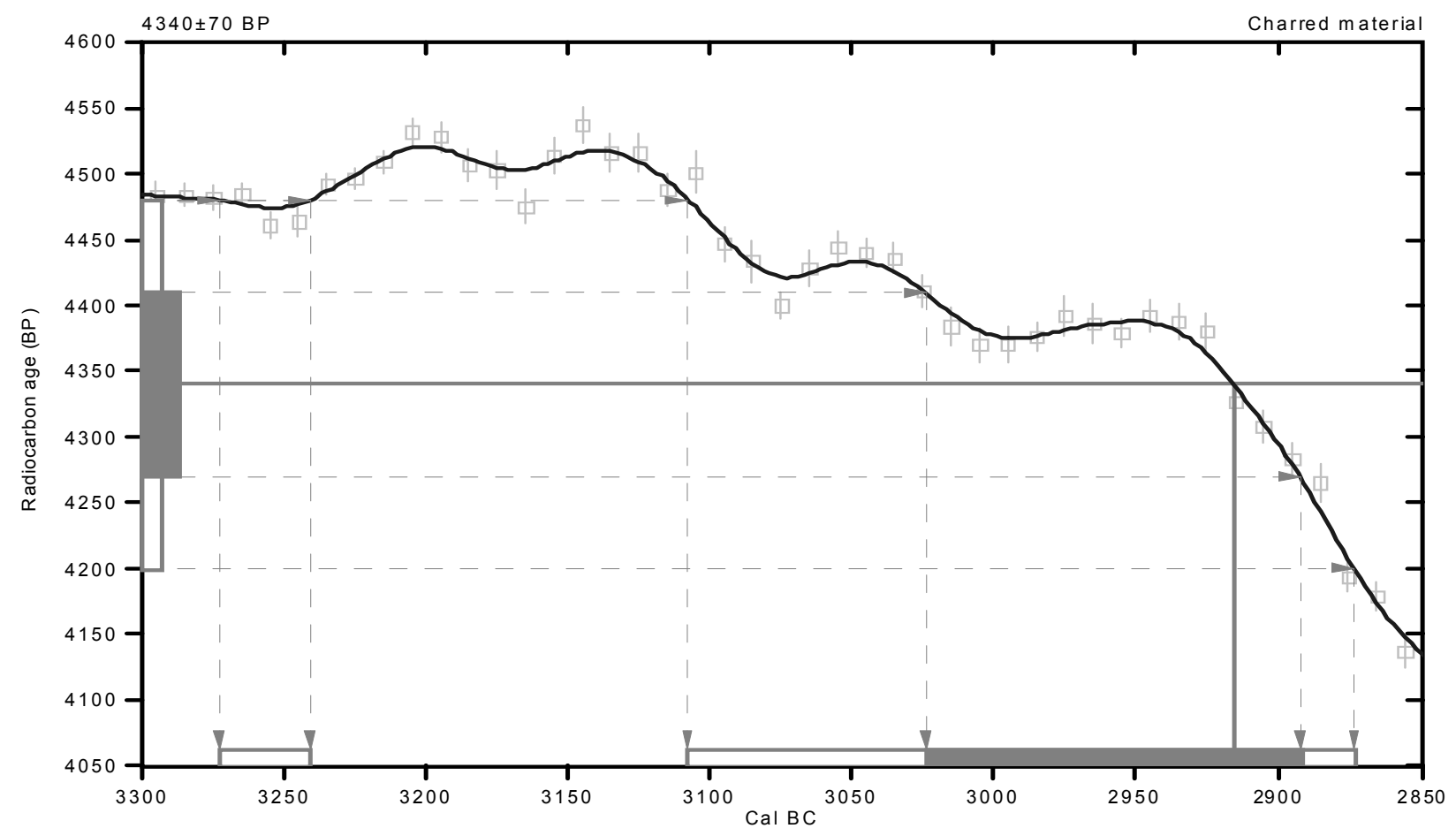

References:

Database used

Calibration Database

Editorial Com ment

Stuiver, M., van der Plicht, H., 1998, Radiocarbon 40(3), pxii-xiii

INTCAL98 Radiocarbon Age Calibration

Stuiver, M., et. al., 1998, Radiocarbon 40(3), p1041-1083

$M$ athem atics

A Simplified Approach to Calibrating C14 Dates

Talma, A.S., Vogel, J. C., 1993, Radiocarbon 3 5(2), p317-322

\section{Beta Analytic Inc.}

4985 SW 74 Court, Miami, Florida 33155 USA Tel: (305)6675167•Fax:(305)6630964・E-Mail: beta@radiocarbon.com 


\section{CALIBRATION OF RADIOCARBON AGE TO CALENDAR YEARS}

$$
\text { (V ariables: C } 13 / \mathrm{C} 12=-18.5: 1 \mathrm{ab} . \mathrm{mult}=1 \text { ) }
$$

Laboratory number: Beta-166721

Conventional radiocarbon age: $2930 \pm 40$ BP

2 Sigm a calibrated result: Cal BC 1270 to 1000 (Cal B P 3220 to 2950) (95\% probability)

Intercept data

Intercept of radiocarbon age

with calibration curve:

Cal B C 1120 (Cal B P 3070$)$

1 Sigma calibrated result: Cal BC 1200 to 1040 (Cal B P 3150 to 2990) (68\% probability)

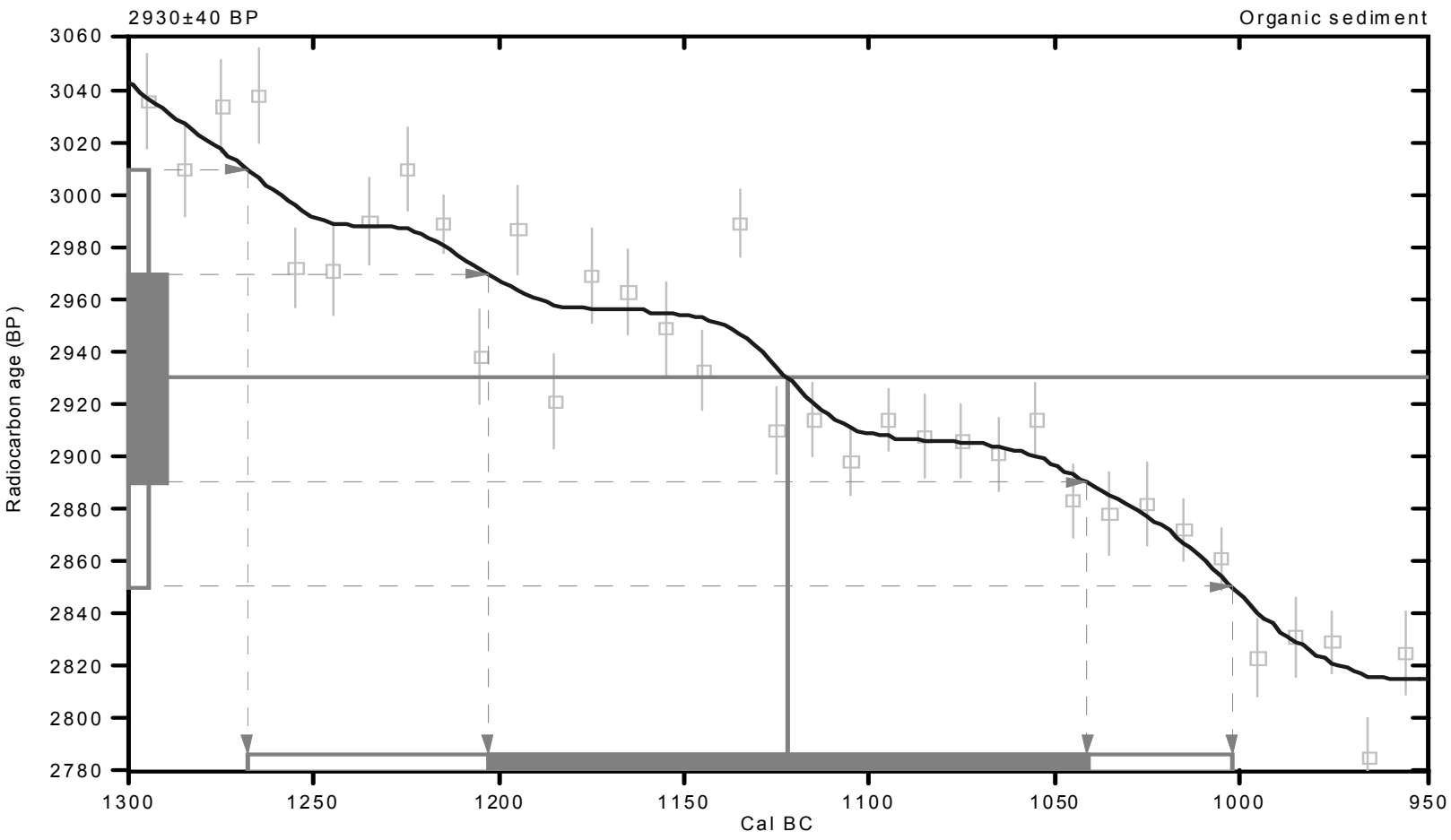

References:

Database used

Calibration Databa se

Editorial Com ment

Stuiver, M., van der Plicht, H., 1998, Radioca rbon 40(3), pxii-xiii

IN TCAL 98 Radiocarbon Age Calibration

Stuiver, M., et. al., 1998, Radiocarbon 40(3), p1041-1083

$M$ ath ematics

A Simplified Approach to Calibrating C14 Dates

Talma, A. S., Vogel, J. C., 1993, Radiocarbon 35(2), p317-322

\section{Beta Analytic Inc.}

4985 SW74 Court, Miami, Florida 33155 USA Pel: (305)6675167•Fax:(305)6630964・E-Mail: beta@radiocarbon.com 



\title{
Appendix C
}

\section{Magnetic Sediment Susceptibility}

\author{
by \\ Raymond P. Mauldin
}




\title{
Appendix C: Magnetic Sediment Susceptibility
}

\author{
Raymond P. Mauldin
}

\section{Introduction}

The magnetic susceptibility (MS) of a given sediment sample can be thought of as a measure of how easily that sample can be magnetized (Dearing 1999; Gose and Nickels 2001). At low magnetic field strengths, this measure is primarily related to the concentration and grain size of ferro and ferromagnetic minerals in the sample (Gose and Nickels 2001). A number of processes can result in an increase in MS values in a sediment sample. Of these processes, those that are of concern here are related to an increase in the organic constitutes or changes in the mineralogy of sediments in a given sample (see Collins et al. 1994; McClean and Kean 1993; Singer and Fine 1989). Sediments with higher organic content tend to have higher magnetic susceptibility values, probably as a result of the production of maghemite, an iron oxide, during organic decay (Reynolds and King 1995). Pedogenic processes, such as soil formation and weathering, can result in the concentration of organic material, as well as alterations in the mineralogy of a given zone. These processes can significantly impact susceptibility readings. Cultural processes, such as the concentration of ash, charcoal, and refuse, would also produce higher MS readings. A measure of the magnetic susceptibility of a sediment sample, then, may provide information on both the presence of surfaces, as well as a measure of the concentration of cultural activity upon those surfaces.

\section{Collection Procedures and Laboratory Methods}

A total of 10 samples was processed for magnetic sediment susceptibility from Unit 21 at 41CM111. All samples were collected at $5-\mathrm{cm}$ intervals along a given vertical stretch of the excavation unit. All sediment samples were air dried on a non-metal surface. After drying, the samples were then ground to a uniform grain size using a ceramic mortar and pestle. This was done to standardize particle size and make the material both easier to handle and pack into sample containers. After each sample was ground, the mortar and pestle were washed with tap water and wiped dry with a paper towel to avoid cross-sample contamination. The ground sample was then poured into a sample container consisting of a plastic cube with external dimensions of $2.54 \times 2.54 \mathrm{x}$ $1.94 \mathrm{~cm}$. The cubes have an average weight of 4.83 grams. The sediment filled cube was then weighed, and the weight of the sample calculated by subtracting the empty cube weight. This was done to correct for differences in mass. Assuming that sample volume and material are constant, larger samples should have higher susceptibility values simply as a function of greater mass.

The cube was then placed into a MS2B Dual Frequency Sensor that, in conjunction with a MS2 Magnetic Susceptibility Meter, provided a measure of the magnetic susceptibility of the sample (see Dearing 1999). For each cube, three distinct readings were taken using the SI (standard international) scale. These were averaged to provide a single reading. The value, referred to as volume specific susceptibility and noted with the symbol $\mathrm{K}$ (Kappa), is recorded on a scale of $10^{-5}$, though there are no units associated with the value. That is, the value is dimensionless (Dearing 1999).

In order to correct for differences in sample weight, and provide units to the value $K$, the mass specific susceptibility value (X) was calculated using the formula,

$$
\mathrm{X}=\left(\mathrm{K}_{0} / \mathrm{p}\right)
$$

where $\mathrm{p}$ is the sample bulk density expressed in $\mathrm{kg} \mathrm{m}^{-3}$. The bulk density is determined by dividing the sample mass by volume. However, as all samples were measured in identical cubes, and all cubes were full, the sample volume is assumed to be constant. Only the mass of the sample varied. Mass specific susceptibility can be determined by,

$$
\mathrm{X}=(\mathrm{K} * \text { calibrated mass }) / \text { sample mass }
$$

where sample mass is determined by subtracting the cube weight from the total sample weight (Dearing 1999). Calibrated mass is assumed to be 10 grams. 
While the resulting values now have both a scale and associated units, the critical element for the current discussion is related to relative differences between X sample values within a given profile or site, rather than absolute differences. That is, the principal interest is in rapid changes in the mass specific susceptibility values along a profile. This change may signal either a buried surface and/or cultural activity at that location. Comparisons of absolute values between samples from different areas, especially when the parent material of the soils is different, are of limited utility given our current goals.

This can be seen in Table $\mathrm{C}-1$, which lists a variety of examples of mass specific susceptibility values for several different materials. In all cases, the analysis was performed following the procedures outlined previously. Note that the values differ widely, from a low of -1.47 for tap water, to a high of 97.62 for sediments collected from a burned rock midden. Samples 5 and 6 are of two different clays from the same general setting, far northern Lamar County in north Texas. The mass specific susceptibility is different for these samples, probably as a function of different frequencies of trace elements that, though small in absolute quantity, can dramatically impact the susceptibility values.

The potential impacts of cultural processes on susceptibility values can be seen by considering a data set collected from an archeological site located in Brown County, 41BR473. A total of 279 sediment susceptibility samples was collected from each level of over 50 shovel tests placed at this site. In all cases, the analytical procedures followed those outlined previously. Table C-2 presents summary data on all 279 cases, along with susceptibility scores for those settings that had firecracked rock (FCR) or chipped stone present. If cultural inputs result in higher susceptibility values, then it should be the case that significantly higher susceptibility values will be present in levels that have cultural material.

Table C-1. Magnetic sediment susceptibility data for a variety of substances

\begin{tabular}{|l|c|c|c|c|c|c|c|}
\hline \multicolumn{1}{|c|}{ Sample Type } & $\begin{array}{c}\text { Total } \\
\text { Wt. (gr.) }\end{array}$ & $\begin{array}{c}\text { Sample } \\
\text { Wt. (gr.) }\end{array}$ & $\begin{array}{c}\text { Reading } \\
\mathbf{1}(\mathbf{k})\end{array}$ & $\begin{array}{c}\text { Reading } \\
\text { 2 (k) }\end{array}$ & $\begin{array}{c}\text { Reading } \\
\mathbf{3 ( k )}\end{array}$ & $\begin{array}{c}\text { Average } \\
\text { K }\end{array}$ & $\begin{array}{c}\text { Corrected } \\
\text { Mass (X) }\end{array}$ \\
\hline $\begin{array}{l}\text { 1) Sandy } \\
\text { sediment with } \\
\text { organics }\end{array}$ & 13.7 & 8.85 & 27.9 & 28 & 28.1 & 28.00 & 31.64 \\
\hline $\begin{array}{l}\text { 2) Modern } \\
\text { mesquite } \\
\text { charcoal and } \\
\text { sediment }\end{array}$ & 9.4 & 4.55 & 10.7 & 10.8 & 10.7 & 10.73 & 23.59 \\
\hline $\begin{array}{l}\text { 3) Modern oak } \\
\text { wood ash }\end{array}$ & 7.5 & 2.65 & 16.1 & 16.2 & 16.2 & 16.17 & 61.01 \\
\hline $\begin{array}{l}\text { 4) Sediment from } \\
\text { burned rock } \\
\text { midden }\end{array}$ & 11.3 & 6.45 & 62.9 & 63 & 63 & 62.97 & 97.62 \\
\hline $\begin{array}{l}\text { 5) Gray clay- } \\
\text { no human } \\
\text { occupation }\end{array}$ & 12.6 & 7.75 & 10.4 & 10.3 & 10.4 & 10.37 & 13.38 \\
\hline $\begin{array}{l}\text { 6) Red clay- } \\
\text { no human } \\
\text { occupation }\end{array}$ & 10.8 & 5.95 & 11.9 & 12 & 12 & 11.97 & 20.11 \\
\hline 7) Sandstone & 14.7 & 9.85 & 6.9 & 7 & 7.1 & 7.00 & 7.11 \\
\hline 8) Limestone & 12.7 & 7.85 & -0.5 & -0.5 & -0.5 & -0.50 & -0.64 \\
\hline 9) Tap water & 10.5 & 5.65 & -0.8 & -0.8 & -0.9 & -0.83 & -1.47 \\
\hline
\end{tabular}


Table C-2. Presence/absence of cultural material and mass specific sediment susceptibility scores for shovel tests at 41BR473

\begin{tabular}{|c|c|c|c|c|c|}
\hline & All Cases & $\begin{array}{c}\text { FCR } \\
\text { Present }\end{array}$ & $\begin{array}{c}\text { FCR } \\
\text { Absent }\end{array}$ & $\begin{array}{c}\text { Chipped Stone } \\
\text { Present }\end{array}$ & $\begin{array}{c}\text { Chipped Stone } \\
\text { Absent }\end{array}$ \\
\hline $\begin{array}{c}\text { Number } \\
\text { of Samples }\end{array}$ & 279 & 84 & 195 & 38 & 241 \\
\hline Mean Value & 48.3 & 56.9 & 44.6 & 55.2 & 47.2 \\
\hline $\begin{array}{c}\text { Standard } \\
\text { Deviation }\end{array}$ & 17.2 & 17.7 & 15.6 & 16.1 & 17.1 \\
\hline
\end{tabular}

An examination of Table $\mathrm{C}-2$ will demonstrate that this is indeed the case. Levels that have FCR present do have higher scores relative to those that lack FCR. Similarly, those levels that have chipped stone present have a higher average mass specific susceptibility score relative to those that lack chipped stone. As the distribution is approximately normal, a t-test was used to test the overall significance of these differences. In both the FCR and chipped stone comparisons, the test confirms that those levels with cultural material have significantly higher scores than those without cultural material (FCR t-statistic $=5.804, \mathrm{df}=277, \mathrm{p}<.001$; chipped stone t-statistic $=2.674, \mathrm{df}=277, \mathrm{p}=.008$ ). Our preliminary investigations, then, coupled with the previous work, clearly suggest that an analysis of the magnetic susceptibility of sediment can provide additional information on both the presence of buried surfaces, as well as the impact of cultural material on those surfaces.

Table C-3 presents the raw data for the 10 samples from Unit 21 at 41CM111. Overall, the samples values ranged from a low of 26.14 to a high of 31.97. An examination of the values suggests that two peaks may be present, with the first occurring at between 30 and about $40 \mathrm{cmbs}$ and a more distinct peak occurring between 80 and 90 cmbs. One interpretation of the changes in the values is that two buried surfaces may be present.

Given that somewhere around $20 \mathrm{~cm}$ of matrix was apparently removed via roadway-related grading from the south side of the road during the 1990s (Rick Hanks, personal communication 2002), the peaks exhibited in Unit 21 would align well with artifact densities contained within the 1980 main excavation block. Specifically, the first peak in MS values expressed between 30 and $40 \mathrm{cmbs}$ may correspond to the slight increase in artifacts exhibited in the main block north of FM 306. Correspondingly, the lower peak in MS values expressed between 80 and $90 \mathrm{cmbs}$ would correspond with the increase in cultural material occurring below the burned rock sheet midden in the main excavation block.

Table C-3. Magnetic susceptibility values for the 10 samples from Unit 21, 41CM111

\begin{tabular}{|c|c|c|c|c|c|c|c|c|c|}
\hline Site & Unit & Level & Depth & Weight & R1 & R2 & Average & Value & Plotted \\
\hline 41CM111 & 21 & A & $0-10$ & 13.4 & 22.3 & 22.5 & 22.4 & 26.14 & 5 \\
\hline 41CM111 & 21 & B & $10-20$ & 13.4 & 24.2 & 23.9 & 24.05 & 28.06 & 15 \\
\hline 41CM111 & 21 & C & $20-30$ & 13.3 & 24.0 & 24.2 & 24.1 & 28.45 & 25 \\
\hline 41CM111 & 21 & D & $30-40$ & 13.3 & 25.1 & 24.8 & 24.95 & 29.46 & 35 \\
\hline 41CM111 & 21 & E & $40-50$ & 13.3 & 23.0 & 23.3 & 23.15 & 27.33 & 45 \\
\hline 41CM111 & 21 & F & $50-60$ & 13.4 & 23.3 & 23.3 & 23.3 & 27.19 & 55 \\
\hline 41CM111 & 21 & G & $60-70$ & 13.3 & 23.6 & 23.8 & 23.7 & 27.98 & 65 \\
\hline 41CM111 & 21 & H & $70-80$ & 13.3 & 25.0 & 25.1 & 25.05 & 29.57 & 75 \\
\hline 41CM111 & 21 & I & $80-90$ & 13.4 & 27.3 & 27.5 & 27.4 & 31.97 & 85 \\
\hline 41CM111 & 21 & J & $90-100$ & 13.4 & 25.8 & 25.9 & 25.85 & 30.16 & 95 \\
\hline
\end{tabular}




\section{References Cited}

Collins, M. B., W. A. Gose, and S. Shaw

1994 Preliminary Geomorphological Findings at Dust and Nearby Caves. Journal of Alabama Archaeology 40:35-56.

Dearing, J.

1999 Environmental Magnetic Susceptibility. Chi publishing, Kenilworth, England.

Gose, W. A., and D. L. Nickels

2001 Archaeomagnetic and Magnetic Susceptibility Analyses. In Test Excavations at the Culebra Creek Site, 41BX126, Bexar County, Texas, by D. L. Nickels, C. B. Bousman, J. D. Leach, and D. A. Cargill, pp. 204214. Archaeological Survey Report, No. 265, Center for Archaeological Research, The University of Texas at San Antonio. Archeology Studies Program, Report 3, Environmental Affairs Division, Texas Department of Transportation, Austin.

McClean, R. G., and W. F. Kean

1993 Contributions of Wood Ash Magnetism to Archeomagnetic Properties of Fire Pits and Hearths. Earth and Planetary Science Letters 119:387-394.

Reynolds, R. L., and J. W. King

1995 Magnetic Records of Climate Change. U.S. National Report to I.U.G.G., 1991-1994. American Geophysical Union. $<$ http://www.agu.ong/revgeophys/reyno100/reyno100.html $>$ Accessed April 2001.

Singer, M. J., and P. Fine

1989 Pedogenic Factors Affecting Magnetic Susceptibility of Northern California Soils. Soil Science of America Journal 53:1119-1127. 
A list of publications offered by the Center for Archaeological Research is available. Call (210) 458-4378; write to the Center for Archaeological Research, The University of Texas at San Antonio, 6900 N. Loop 1604 W., San Antonio, Texas 78249-0658; e-mail to car@lonestar.utsa.edu; or visit CAR's web site at http://car.utsa.edu. 